UNIVERSIDADE DE SÃO PAULO

FACULDADE DE ECONOMIA, ADMINISTRAÇÃO E CONTABILIDADE DEPARTAMENTO DE CONTABILIDADE E ATUÁRIA PROGRAMA DE PÓS-GRADUAÇÃO EM CIÊNCIAS CONTÁBEIS

A INFLUÊNCIA DOS INCENTIVOS FISCAIS SOBRE A ESTRUTURA DE CAPITAL E A RENTABILIDADE DAS COMPANHIAS ABERTAS BRASILEIRAS NÃO FINANCEIRAS

Henrique Formigoni

Orientador: Prof. Dr. Carlos Alberto Pereira

SÃO PAULO 
Profa. Dra. Suely Vilela

Reitora da Universidade de São Paulo

Prof. Dr. Carlos Roberto Azzoni

Diretor da Faculdade de Economia, Administração e Contabilidade

Prof. Dr. Fábio Frezatti

Chefe do Departamento de Contabilidade e Atuária

Prof. Dr. Gilberto de Andrade Martins

Coordenador do Programa de Pós-Graduação em Ciências Contábeis 


\section{HENRIQUE FORMIGONI}

\section{A INFLUÊNCIA DOS INCENTIVOS FISCAIS SOBRE A ESTRUTURA DE CAPITAL E A RENTABILIDADE DAS COMPANHIAS ABERTAS BRASILEIRAS NÃO FINANCEIRAS}

Tese apresentada ao Departamento de Contabilidade e Atuária da Faculdade de Economia, Administração e Contabilidade da Universidade de São Paulo como requisito para obtenção do título de Doutor em Ciências Contábeis.

Orientador: Prof. Dr. Carlos Alberto Pereira

SÃO PAULO 
Tese defendida e aprovada no Departamento de Contabilidade e Atuária da Faculdade de Economia, Administração e Contabilidade da Universidade de São Paulo - Programa de Pós-Graduação em Ciências Contábeis, pela seguinte banca examinadora:

Prof. Dr. Carlos Alberto Pereira (FEA/USP)

Prof. Dr. Nelson Guedes de Carvalho (FEA/USP)

Prof. Dr. Luiz Paulo Lopes Fávero (FEA/USP)

Prof. Dr. Arthur Ridolfo Neto (FGV/SP)

Prof. Dr. Edilson Paulo (UFPB)

FICHA CATALOGRÁFICA

Elaborada pela Seção de Processamento Técnico do SBD/FEA/USP

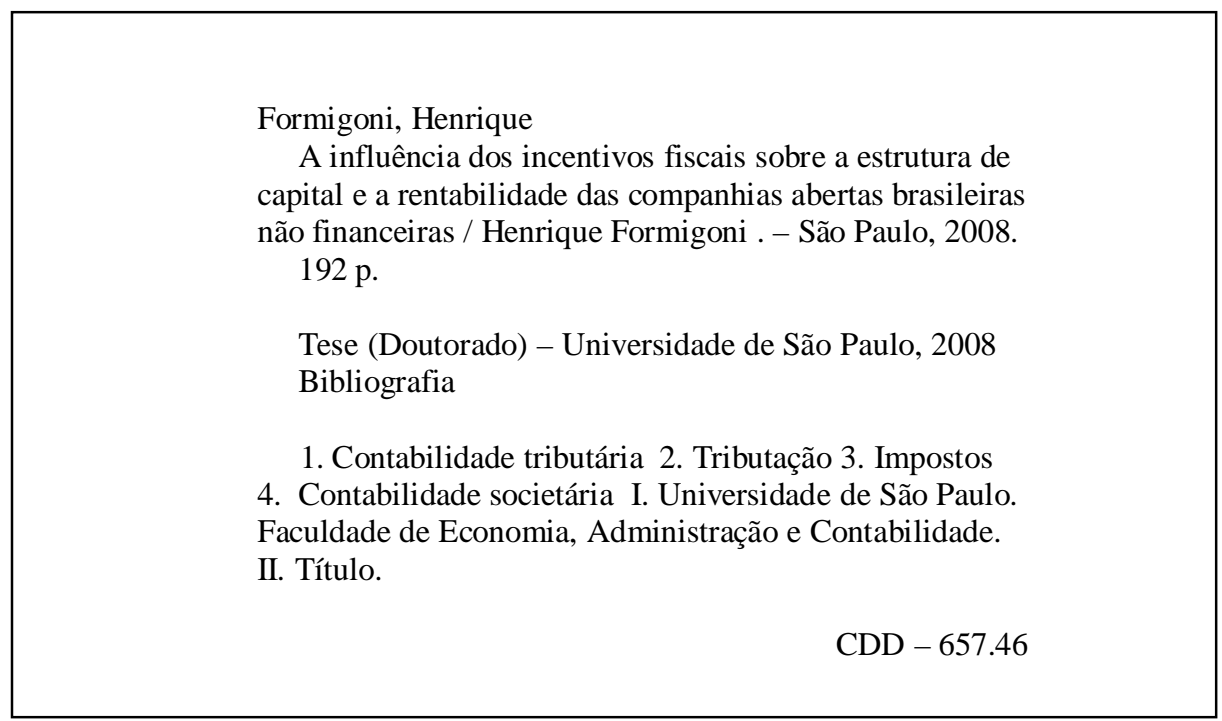


Á Pierina, minha esposa, e a meus filhos e netos. 
A jornada foi árdua, porém não seria possível sem força divina. Agradeço ao bom PAI por ter me apoiado durante toda a caminhada.

Várias pessoas dela participaram, de alguma forma: apoiando, incentivando e contribuindo para a evolução e conclusão deste trabalho, às quais tenho imensa gratidão.

É inestimável a importância do convívio com os amigos da Universidade Presbiteriana Mackenzie - UPM os quais foram muito importantes para a estrutura de um ambiente harmonioso e construtivo. Da mesma forma, o esforço em conjunto e o convívio com os colegas da Universidade de São Paulo - USP foram imprescindíveis para a continuidade do curso.

Agradeço de forma especial:

Ao meu orientador, Prof. Dr. Carlos Alberto Pereira, pelas idéias sugeridas, orientação realizada e pela confiança depositada.

Aos meus professores: Drs. Alexandro Broedel Lopes, Ariovaldo dos Santos, Geraldo Barbieri, Luiz João Corrar, Luiz Nelson Guedes de Carvalho, Luiz Paulo Lopes Fávero e Reinaldo Guerreiro pela dedicação e oportunidade de aprendizado.

Aos Profs. Drs. Gilberto de Andrade Martins, Antonio Carlos Dias Coelho e Luiz Nelson Guedes de Carvalho pelas sugestões oportunas na sessão de discussões metodológicas. Aos professores Arthur Ridolfo Neto e Luiz Paulo Lopes Fávero pelas valiosas sugestões e contribuições oferecidas quando da qualificação desta tese.

Ao amigo Prof. Ms. José Fausto de Morais pela dedicação e colaboração para a conclusão deste trabalho.

À Profa. Dra. Maria Thereza Pompa Antunes que sempre incentivou e apoiou o desenvolvimento deste estudo e pelo convívio de muitos anos.

Aos meus pais, Mário Formigoni (in memorem) e Astrogilda de Paula Formigoni, que sempre estimularam e apoiaram os meus estudos. 
“As partidas dobradas da nossa existência são feitas a débito ou a crédito das nossas ações, tendo como contrapartida os seus resultados."

Anônimo 


\section{RESUMO}

Esta tese tem como objetivo principal avaliar os efeitos dos incentivos fiscais sobre a estrutura de capital e a rentabilidade das companhias abertas brasileiras não financeiras. Sob o aspecto metodológico, este estudo pode ser classificado como do método quantitativo, do tipo descritivo-longitudinal e transversal. A população-alvo do estudo são as companhias abertas brasileiras não financeiras, cuja amostra é composta por aquelas que têm ações negociadas na Bovespa, totalizando 590 empresas, perfazendo um número potencial de registros contábeis de 7.670 no período de 1995 a 2007, cujos dados foram obtidos no banco de dados da Economática. $\mathrm{Na}$ análise transversal, os indicadores de incentivo fiscal, estrutura de capital e rentabilidade, para cada empresa, foram reduzidos aos seus valores médios. A comparação dos referidos indicadores nos grupos sem e com incentivos fiscais foi realizada por meio do teste U de Mann-Whitney para amostras independentes, com utilização da Análise de Homogeneidade (HOMALS) na construção de mapas perceptuais e realização do procedimento GLM Univariate Test para avaliar o efeito da obtenção de incentivos fiscais sobre aqueles indicadores. $\mathrm{Na}$ análise longitudinal, considerou-se o procedimento GLM Multivariate Test na avaliação do efeito da obtenção de incentivos fiscais e do ano em que a operação contábil foi realizada sobre os referidos indicadores. Os resultados do estudo sugerem não haver correlação estatisticamente significativa entre incentivo fiscal e indicadores de estrutura de capital. Por outro lado, identificou-se correlação estatisticamente significativa entre incentivo fiscal e rentabilidade das empresas. 


\begin{abstract}
The main goal of this research is to evaluate the effects of the tax incentives on the capital structure and the profitability of the Brazilian non-financial public companies. Under the methodological aspect, this study can be classified as a quantitative method, in the longitudinal-descriptive and transversal type. The target population of the study is the Brazilian non-financial public companies, which the sampling is composed by those that have stock negotiated in the Bovespa (the Brazilian trading market in São Paulo), totalizing 590 companies, amounting to a potential number of 7,760 registers during the period of 1995 2007, which data were obtained in the data bank of "Economática". In the transversal analyses the tax incentive indicators, were reduced to their average values. The comparison of the above-mentioned indicators in the groups with and without incentive was done by the test $U$ of Mann-Whitney for the independent sampling, by the usage of the Homogeneity Analysis (HOMALS) in the construction of the perception maps and the accomplishment of the GLM Univariate Test procedure to evaluate the effect of obtaining the fiscal incentives under these indicators. In the longitudinal analyses was considered the procedure GLM Multivariate Test in the evaluation of the effect of obtaining the tax incentives and of the year that the accounting operation was done under the referred indicators. The results of the study suggest that there are no meaningful statistical correlation between the tax incentive and the capital structure indicators. On the other hand it was found a meaningful statistical correlation between the tax incentive and the profitability of the companies.
\end{abstract}




\section{SUMÁRIO}

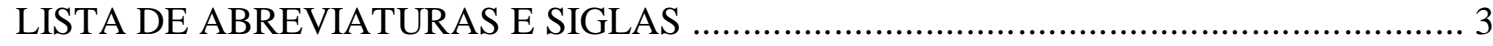

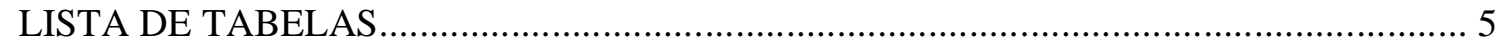

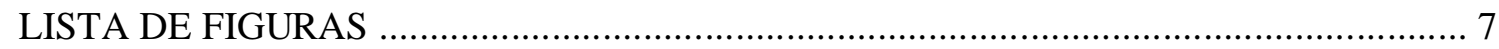

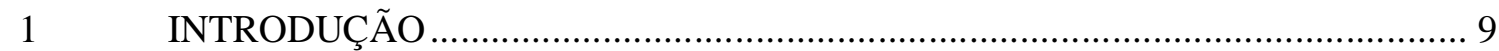

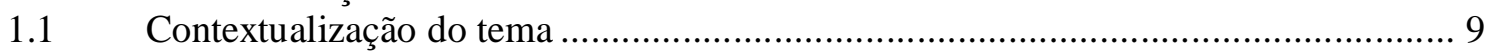

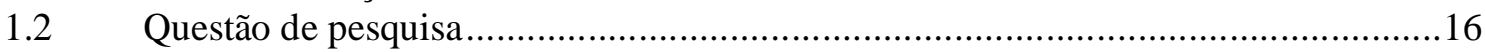

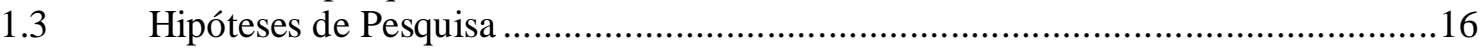

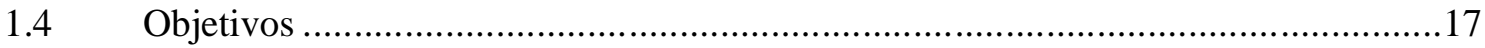

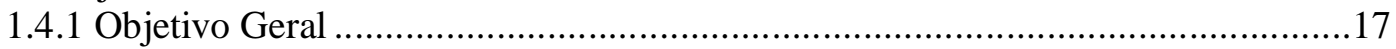

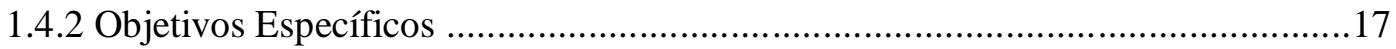

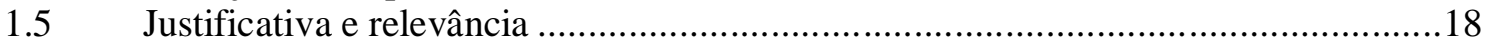

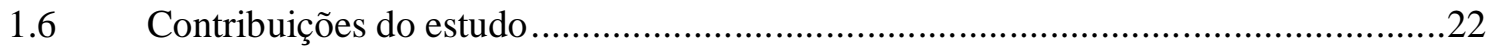

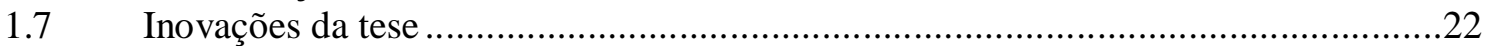

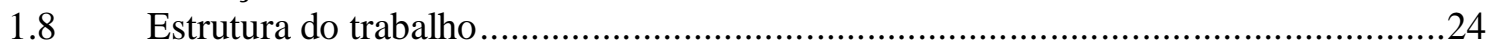

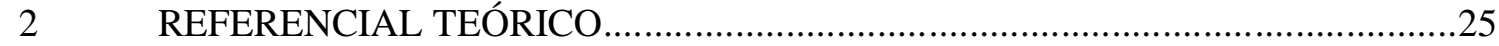

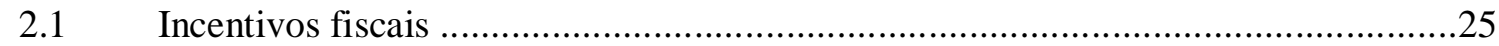

2.1.1 Definição de incentivos fiscais e suas finalidades.......................................25

2.1.2 Renúncia fiscal, benefícios fiscais e incentivos fiscais....................................26

2.1.3 Classificação dos incentivos fiscais .........................................................29

2.1.3.1 Quanto às características das principais espécies......................................30

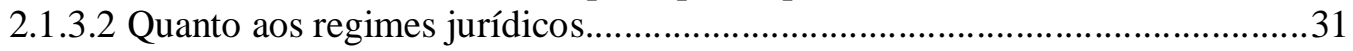

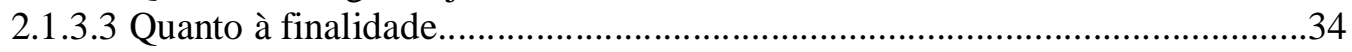

2.1.4 Imunidade, isenção e não-incidência .......................................................... 35

2.1.5 Reconhecimento, mensuração e evidenciação dos incentivos fiscais...................42

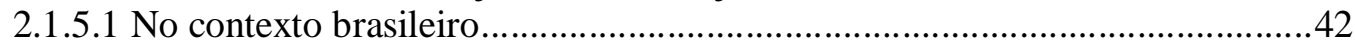

2.1.5.2 Normas Contábeis sobre incentivos fiscais no âmbito internacional..............57

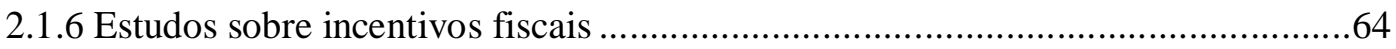

2.1.6.1 Estudos sobre incentivos fiscais realizados no Brasil....................................64

2.1.6.2 Estudos sobre incentivos fiscais realizados no exterior..............................84

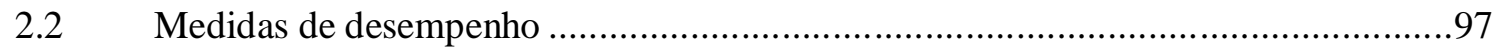

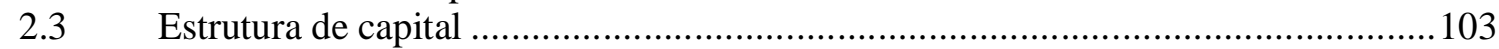

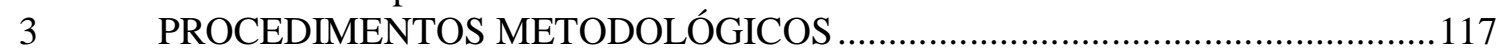

3.1 Desenho da pesquisa e organização do trabalho ................................................. 117

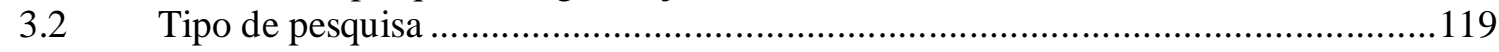

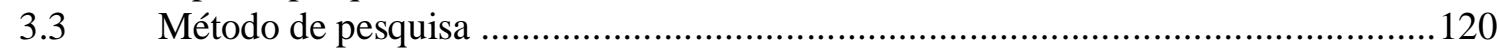

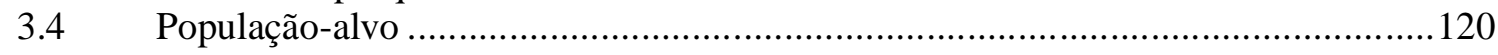

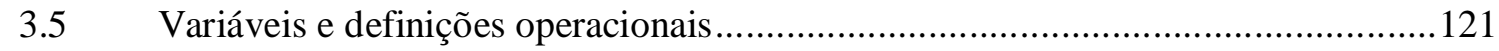

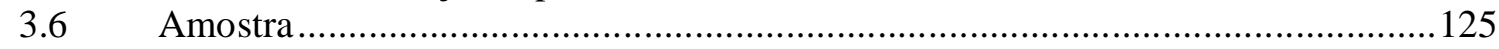

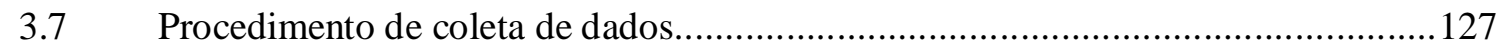

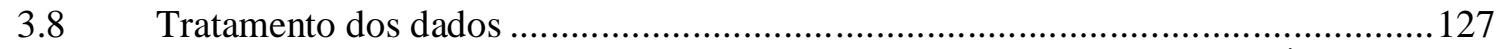

4 APRESENTAÇÃO E TRATAMENTO DOS DADOS E ANÁLISE DOS

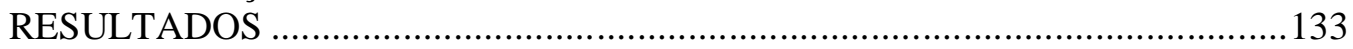

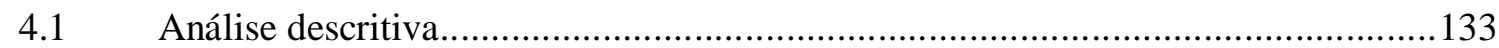

4.2 Análise transversal - abordagem tradicional.................................................... 143

4.3 Análise transversal baseada no método GLM Univariate.......................................149

4.3.1 Modelo GLM Univariate para o estudo do efeito do incentivo fiscal sobre os indicadores de estrutura de capital e rentabilidade............................149

4.4 Análise longitudinal baseada no modelo GLM Multivariate ...............................155 
4.4.1 Modelo GLM Multivariate para o estudo do efeito do incentivo fiscal e do Tempo sobre os indicadores de estrutura de capital e rentabilidade.............................155

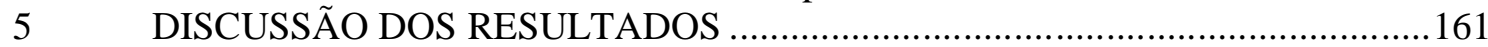

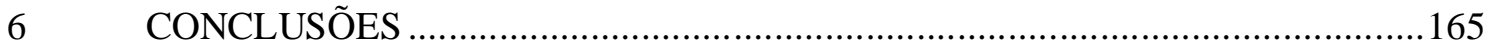

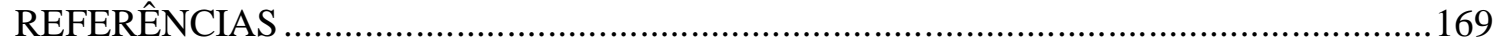




\section{LISTA DE ABREVIATURAS E SIGLAS}

APB: Accounting Principles Board

BNH: Banco Nacional da Habitação

BOVESPA: Bolsa de Valores de São Paulo

CAPES: Coordenação de Aperfeiçoamento de Pessoal de Nível Superior

CE: Comunidade Européia

CETESB: Companhia Estadual de Tecnologia de Saneamento Ambiental

CF: Constituição Federal

CFC: Conselho Federal de Contabilidade

COFINS: Contribuição para Financiamento da Seguridade Social

CPC: Comitê de Pronunciamentos Contábeis

CVM: Comissão de Valores Mobiliários

DEF: Desempenho Econômico Financeiro

DRE: Demonstração do Resultado do Exercício

DSE: Desenvolvimento Socioeconômico

EMBRATUR: Empresa Brasileira de Turismo

EUA: Estados Unidos da América do Norte

FAS: Financial Accounting Standard

FASB: Financial Accounting Standards Board

FINOR: Fundo de Investimento do Nordeste

FISET: Fundo de Investimentos Setoriais

FUNDEB: Fundo de Manutenção e Desenvolvimento da Educação Básica e de Valorização dos Profissionais da Educação

FUNDEF: Fundo de Manutenção e Desenvolvimento do Ensino Fundamental e de Valorização do Magistério

IAS: International Accounting Standards

IASB: International Accounting Standards Board

IASC: International Accounting Standards Committee

IBOVESPA: Índice da Bolsa de Valores do Estado de São Paulo

IBRACON: Instituto dos Auditores Independentes do Brasil

ICMS: Imposto sobre Operações relativas à Circulação de Mercadorias e sobre a Prestação de

Serviços de Transportes Interestadual e Intermunicipal e de Comunicação

IE: Imposto de Exportação

IF: Incentivos Fiscais

IFRS: International Financial Reporting Standards

II: Imposto de Importação

IPECAFI: Instituto Brasileiro de Pesquisas Contábeis, Atuariais e Financeiras

IPI: Imposto sobre Produtos Industrializados

IPTU: Imposto sobre a Propriedade Territorial Urbana

IR: Imposto de Renda

IRC: Internal Revenue Code

IRPF: Imposto de Renda da Pessoa Física

IRPJ: Imposto de Renda da Pessoa Jurídica

IRPQN: Imposto sobre a Renda e Proventos de Qualquer Natureza

IRS: Internal Revenue Service

ISSQN: Imposto sobre Serviços de Qualquer Natureza

ITR: Imposto sobre a Propriedade Territorial Rural

LPE: Lei de Efeito Proporcionado

LSA: Lei das Sociedades Anônimas 
NBC: Norma Brasileira de Contabilidade

NCUA: Administração Nacional das Cooperativas de Crédito

NPC: Normas e Procedimentos de Contabilidade

PAC: Programa de Aceleração do Crescimento

PAT: Programa de Alimentação do Trabalhador

PDTI: Programa de Desenvolvimento Tecnológico Industrial

P\&D: Pesquisa e Desenvolvimento

PIB: Produto Interno Bruto

PIS: Programa de Integração Social

POLOCENTRO: Programa de Desenvolvimento dos Cerrados

PRODECER: Programa de Cooperação Nipo-brasileira de Desenvolvimento dos Cerrados

RAC: Revista de Administração Contemporânea

RAE: Revista de Administração de Empresas

RAP: Revista de Administração Pública

RC\&F: Revista Contabilidade \& Finanças

READ: Revista Eletrônica de Administração

RECOF: Regime Aduaneiro Especial de Entreposto Industrial sob Controle Informatizado

RIR: Regulamento do Imposto de Renda

RL: Receita Líquida

ROA: Return on Assets

ROE: Return on Equity

ROS: Return on Sales

RSU: Resíduos Sólidos Urbanos

SEC: Securities and Exchange Comission

SELIC: Sistema Especial de Liquidação e Custódia

SFAS: Statement of Financial Accounting Standard

STF: Supremo Tribunal Federal

STJ: Superior Tribunal de Justiça

SUDAM: Superintendência do Desenvolvimento da Amazônia

SUDENE: Superintendência do Desenvolvimento do Nordeste

SUS: Sistema Único de Saúde

TMI: Taxa Marginal de Imposto

USGAAP: United States Generally Accepted Accounting Principles

ZFM: Zona Franca de Manaus 


\section{LISTA DE TABELAS}

Tabela 1 - Formação da amostra de empresas e de registros contábeis considerada neste estudo 126

Tabela 2 - Distribuição das empresas de acordo com a obtenção de incentivo fiscal, o tipo de ação e o setor de atividade

Tabela 3 - Distribuição de freqüências e medidas resumo das variáveis: tempo de operação, tempo de incentivo fiscal, taxa unitária do nível de tributação e taxa unitária do crescimento médio anual das vendas....

Tabela 4 - Número anual de empresas sem e com incentivos fiscais no período de 1996 a 2007.

Tabela 5 - Distribuição das variáveis PAIF e VMIF no conjunto das empresas com incentivo fiscal.

Tabela 6 - Distribuição das variáveis ROAm, ROEm, LERm, DERm e DCRm no conjunto das empresas e nos grupos de empresas sem e com incentivo fiscal.......................145

Tabela 7 - Média e desvio padrão dos indicadores de estrutura de capital e rentabilidade....150

Tabela 8 - Teste de esfericidade de Bartlett. 150

Tabela 9 - Teste de Levene da igualdade de variâncias 151

Tabela 10 - Teste de igualdade das matrizes de covariância de Box

Tabela 11 - Testes multivariados

Tabela 12 - Testes de efeitos entre elementos do modelo

Tabela 13 - Estimação de parâmetros da regressão de cada variável dependente sobre OIF.154

Tabela 14 - Resultado do Teste de esfericidade de Bartlett..................................................156

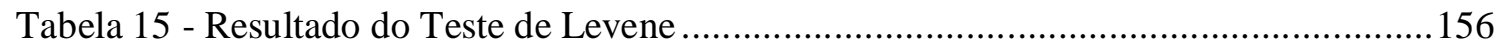

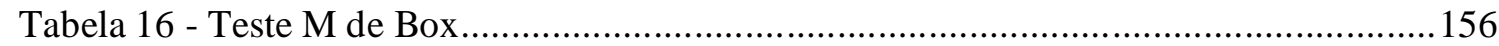

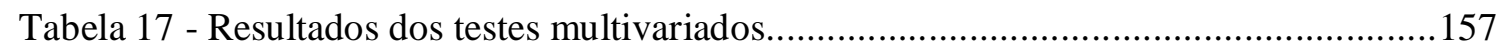

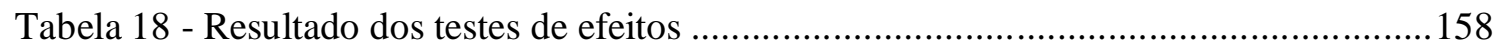




\section{LISTA DE FIGURAS}

Figura 1 - Evolução da carga tributária brasileira de 1991 a 2006 .......................................10

Figura 2 - Natureza fiscal, extrafiscal e parafiscal dos tributos ..........................................12

Figura 3 - Síntese da ligação entre os incentivos fiscais, a estrutura de capital e a

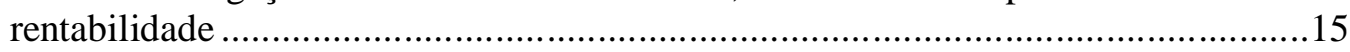

Figura 4 - Estrutura da questão de pesquisa focada no estudo...............................................16

Figura 5 - Total renunciado de receitas e despesas de diversas funções de governo no ano

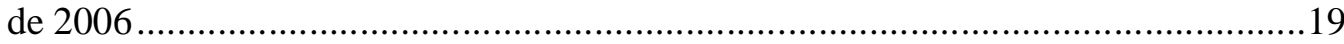

Figura 6 - Inovação da tese para os estudos sobre a estrutura de capital ...............................23

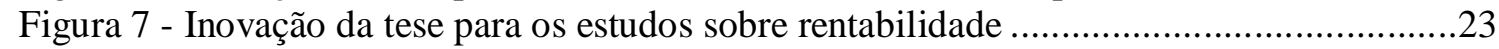

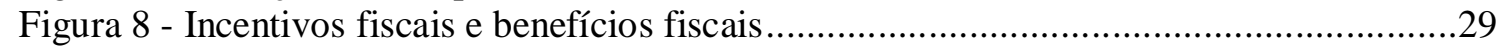

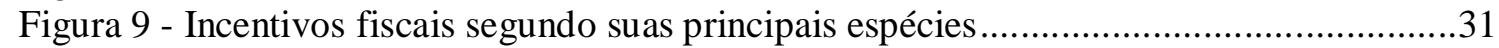

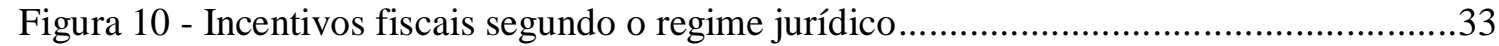

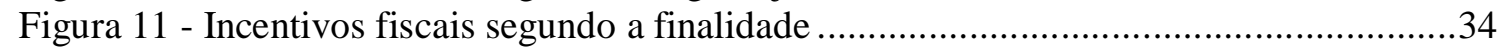

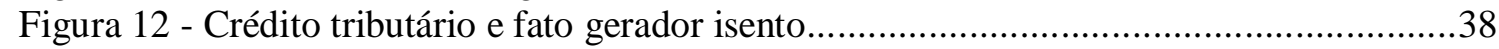

Figura 13 - A isenção como forma de impedimento tributário............................................. 1

Figura 14 - Síntese dos conceitos das figuras da imunidade, não-incidência e isenção...........40

Figura 15 - Síntese evolutiva dos órgãos e das normas contábeis nos EUA e na CE ..............59

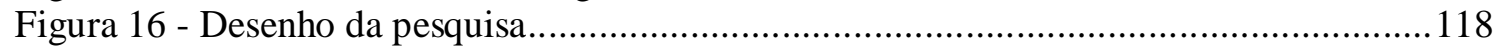

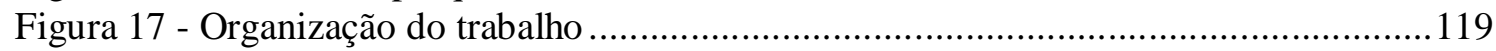

Figura 18 - Análise Transversal por meio do Teste U de Mann-Whitney............................129

Figura 19 - Análise Transversal por meio do GLM Univariate Test ...................................129

Figura 20 - Análise Longitudinal por meio do GLM Multivariate Test..............................130

Figura 21 - Distribuição das empresas de acordo com a obtenção do incentivo fiscal ..........133

Figura 22 - Mapa perceptual das variáveis incentivo fiscal, classe da ação e setor de atividade: análise de homogeneidade (HOMALS) ............................................135

Figura 23 - Error Bar de proporções de empresas em cada setor de estudo com e sem

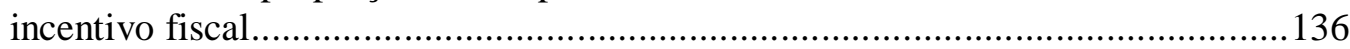

Figura 24 - Mapa perceptual das variáveis incentivo fiscal, tempo de operação, nível de tributação e crescimento de vendas: análise de homogeneidade (HOMALS) ..........140

Figura 25 - Error Bar de médias das variáveis TOP, NTm e CRESV sem e com

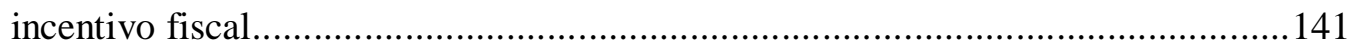

Figura 26 - Percentual anual do número de empresas sem e com incentivos fiscais no

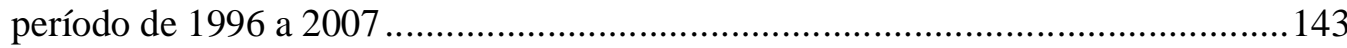

Figura 27 - Box plot para as variáveis ROAm, ROEm, LERm, DERm e DCRm para o

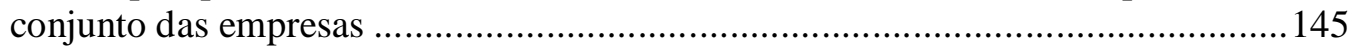

Figura 28 - Box plot para as variáveis ROAm, ROEm, LERm, DERm e DCRm para as empresas sem incentivos fiscais ....................................................................... 146

Figura 29 - Box plot para as variáveis ROAm, ROEm, LERm, DERm e DCRm para as empresas com incentivos fiscais ......................................................................... 147

Figura 30 - Error Bar de médias das variáveis ROAm, ROEm, LERm, DERm e DCRm em empresas sem e com incentivos fiscais ....................................................... 148

Figura 31 - Incentivos fiscais e desempenho econômico financeiro .................................149

Figura 32 - Relação entre incentivos fiscais e estrutura de capitais e retorno considerando

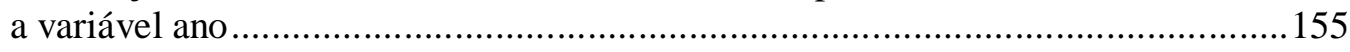

Figura 33 - Modelo de Pesquisa de relacionamento entre incentivos fiscais, os indicadores de estrutura de capital e os de rentabilidade 


\section{INTRODUÇÃO}

\subsection{Contextualização do tema}

Os incentivos fiscais estão diretamente relacionados aos tributos, que são arrecadados pelo Estado e servem de fonte de financiamento para as atividades constitucionais por ele desenvolvidas em benefício da população no âmbito da saúde, educação, segurança, habitação, transporte e outros.

A carga tributária de um país representa a parcela de recursos que o Estado retira, compulsoriamente, dos indivíduos e empresas, como forma principal de financiar o conjunto das atividades do governo. O conceito econômico de carga tributária é o quociente entre a receita tributária total e o valor do Produto Interno Bruto - PIB do país, em determinado exercício fiscal. (BRASIL, 2007, p. 17).

No Brasil, a carga tributária vem se elevando a cada ano e, entre outras coisas, o alto custo da máquina administrativa estatal dificulta a sua redução. Acompanhando a tendência observada nos anos anteriores, a carga tributária brasileira manteve a trajetória ascendente, conforme evidenciado na Figura 1, atingindo, em 2006, a marca de 38,8 \% do PIB. 


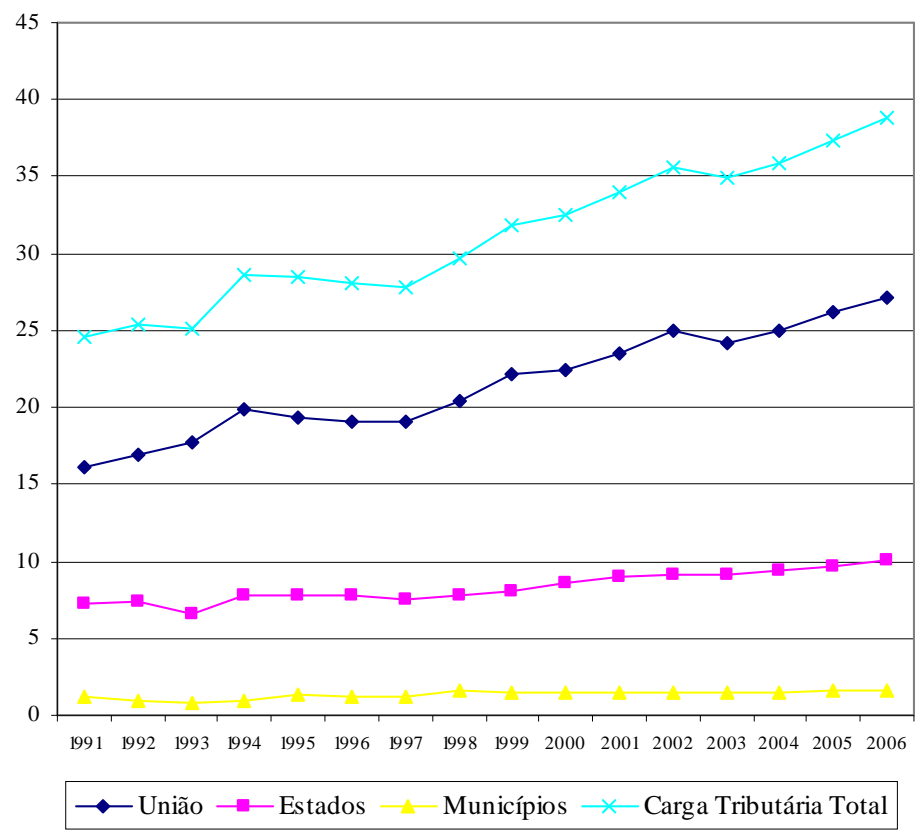

Figura 1 - Evolução da carga tributária brasileira de 1991 a 2006 Fonte: Secretaria da Receita Federal do Brasil

Muito embora a função primordial dos tributos seja a de prover recursos para o Estado, adicionalmente, os tributos servem a outros objetivos de natureza social, política e econômica, situação em que ele adquire uma configuração extrafiscal, na qual são criados os incentivos fiscais que é o objeto de estudo deste trabalho.

Os tributos podem ser distinguidos, ou classificados, dentre outras possibilidades, de acordo com a sua natureza fiscal, extrafiscal ou parafiscal. O tributo tem natureza fiscal quando objetiva prover as necessidades de recursos para os gastos públicos. A arrecadação do Imposto sobre a Propriedade de Veículos Automotores (IPVA), cuja finalidade é a manutenção de rodovias, é um exemplo de natureza fiscal. Com relação à sua natureza extrafiscal o tributo objetiva atender a situações sociais, políticas e econômicas relevantes no contexto nacional. A isenção do imposto de renda para as pessoas jurídicas domiciliadas em determinadas áreas geográficas é um exemplo da natureza extrafiscal. O tributo é classificado como parafiscal quando tem o objetivo de atender a situações particulares de certo grupo social. Existe a parafiscalidade quando o tributo é arrecadado por pessoa distinta daquela que o criou, como, por exemplo, a Contribuição para Seguro de Acidente de Trabalho (SAT), instituída pela União Federal e cobrada pelo INSS. (PIRES, 2007, p. 17). 
A função extrafiscal do tributo evidencia-se, com maior freqüência, nos tributos federais, como, por exemplo: o Imposto de Importação (II) e o Imposto de Exportação (IE), utilizados como instrumentos de política econômica; o Imposto sobre a Propriedade Territorial Rural (ITR), que disciplina o uso da propriedade rural e combate latifúndios improdutivos e o Imposto sobre a Renda e Proventos de Qualquer Natureza (IRPQN), que promove a redistribuição de riqueza. Quanto aos impostos estaduais e municipais, por natureza, não apresentam características da extrafiscalidade. Ressalte-se a importância do Imposto sobre Operações relativas à Circulação de Mercadorias e sobre a Prestação de Serviços de Transportes Interestadual e Intermunicipal e de Comunicação - ICMS, que se transformou em mecanismo de atração de investimentos mediante a concessão de incentivos fiscais, gerando a chamada "guerra fiscal". (PIRES, 2007, p. 28-29).

A característica de redistribuição de riqueza atribuída ao IRPQN é, provavelmente, decorrente da progressividade desse imposto, ou seja, da intenção governamental de redistribuir riqueza tributando, por exemplo, a taxas mais elevadas aqueles que têm renda (ou lucro) mais elevada(o). Porém, em função de situações autorizadas pela legislação como, por exemplo, a dedução de despesas médicas, pelas pessoas físicas, o imposto que era progressivo transforma-se em regressivo e, assim, em vez de redistribuir renda acaba concentrando-a ainda mais. Dessa forma, o imposto que teria a função de equalizar a renda acaba aprofundando a desigualdade de riqueza.

Considerando a natureza extrafiscal, o poder tributante utiliza o mecanismo de renúncia fiscal, abrindo mão de parte da arrecadação de tributos de sua competência, em favor de áreas e atividades que necessitem de apoio para desenvolvimento. A renúncia fiscal, ou extrafiscalidade, é a forma pela qual o Estado utiliza os tributos para alcançar outros fins que não o de arrecadação, como, por exemplo, para incentivar certas atividades ou regiões. Ressalte-se que a renúncia fiscal de alguns tributos, referentes a determinadas atividades, acaba tornando necessária a criação de outros para cobrir o déficit das finanças públicas. (ELALI, 2007, p. 53; FABRETTI, 2000, p. 301-302; MONTEIRO, 2007, p. 359).

A Figura 2 apresenta um resumo da natureza fiscal, extrafiscal e parafiscal dos tributos. 


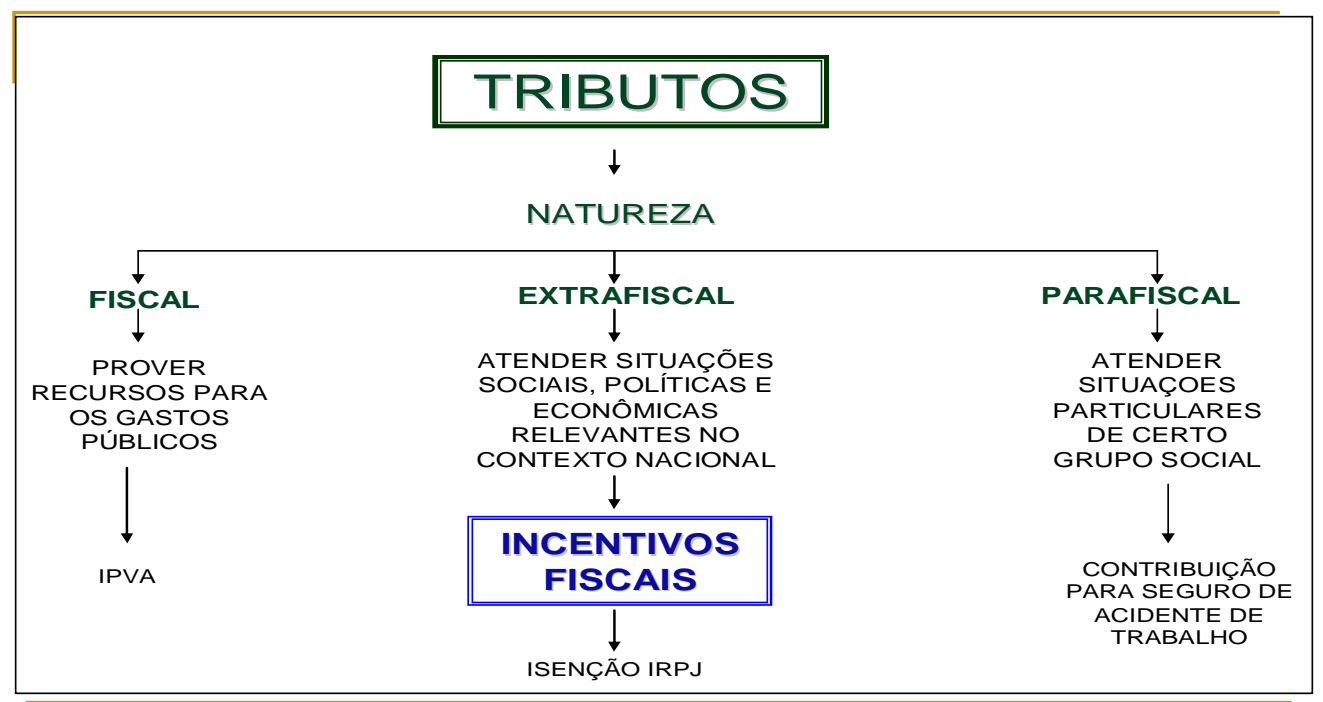

Figura 2 - Natureza fiscal, extrafiscal e parafiscal dos tributos

Segundo Ronaldo Lázaro Medina (FOLHA DE S.PAULO, 2007), coordenador-geral de Política Tributária do governo Luiz Inácio Lula da Silva, houve um aumento do volume de incentivos fiscais, parte em função da expansão da economia, que fez subir a base de arrecadação e, conseqüentemente, o resultado das isenções e reduções de alíquotas, e outra parte em função dos novos incentivos concedidos pelo presidente Lula, principalmente a partir de 2004. Só o Programa de Aceleração do Crescimento (PAC) é responsável pelo aumento dos incentivos em 6,2 bilhões de reais.

Concordando com Fabretti (2000), Medina (FOLHA DE S.PAULO, 2007) chama a atenção para a 'relação perversa' entre carga tributária elevada e renúncias crescentes, que seriam uma espécie de efeito colateral dos impostos altos. Medina estima que, enquanto em 2003 os incentivos representavam pouco mais que $10 \%$ dos tributos e 1,7\% do PIB, em 2007 a estimativa era a de que os incentivos deveriam alcançar $13 \%$ dos tributos diretamente arrecadados pela Receita Federal ou uma fatia equivalente a 2,3\% do PIB.

Com relação aos incentivos fiscais, Guthmann (1951, p. 161) entende a “[...] isenção tributária como um fator que dá a certos tipos de negócios uma vantagem sobre unidades comerciais concorrentes que pagam aqueles impostos" nos Estados Unidos da América do 
Norte - EUA. ${ }^{1}$ Da mesma forma, Rodrigues (2007, p. 321) afirma que, no Brasil, as empresas que se beneficiam de incentivos fiscais desfrutam de uma vantagem competitiva sobre as demais.

A isenção fiscal para as cooperativas de crédito nos EUA tem gerado diversas pesquisas empíricas. Goddard et al. (2002, p. 1) afirmam que, em virtude da flexibilização na regulamentação das cooperativas de crédito nos EUA, introduzindo interpretações menos restritivas das obrigações comuns exigidas para os seus participantes, foram criadas novas oportunidades de concentração e crescimento, sendo que:

Entre 1987 e 1999 o número de cooperativas de crédito declinou de 15.000 para 10.858 enquanto o número de membros aumentou de 53 milhões para 76,6 milhões. O crescimento na concentração é refletido, também, no aumento do tamanho do ativo médio das 20 maiores cooperativas de crédito, de \$ 571 milhões de dólares em 1987 para \$ 1.920 milhões em $1.999 .^{2}$

Explicando o crescimento das cooperativas de crédito nos EUA, Tatom (2005, p. 1-2) afirma que:

Corroborado por outros estudos de cooperativas de créditos e bancos, a evidência direta e indireta colhida por este estudo mostra que os proprietários do patrimônio das cooperativas de crédito recebem a isenção tributária como retornos extraordinários. Entretanto, esses retornos extraordinários não aparecem como dividendos relativamente altos. Assim, eles ocorrem como grandes volumes de lucros retidos no patrimônio líquido em suas cooperativas de crédito. O lucro extra dos proprietários reinvestido na cooperativa de crédito fornece novo capital que permite à cooperativa de crédito crescer mais rápido do que outras instituições. ${ }^{3}$

Ressaltando o efeito da isenção fiscal das cooperativas de crédito, Tatom (2005, p. 22) explica que as "Pesquisas sobre empreendimentos patrocinados pelo governo e sobre cooperativas de créditos suportam a visão de que a principal incidência da isenção fiscal é um aumento no total dos ativos e no índice patrimônio líquido/ativo total do setor da cooperativa de crédito."4

\footnotetext{
1 "tax exemption as a factor giving certain kinds of business an advantage over competing business units which pay such taxes."

2 "Between 1987 and 1999 the number of credit unions declined from 15,000 to 10,858, while the number of members increased from 53 million to 76.6 million Growth in concentration is also reflected in an increase in the median asset size of the largest 20 credit unions, from \$571 million in 1987 to \$1,920 million in 1999."

3 "Corroborated by other studies of credit unions and banks, the direct and indirect evidence gathered for this study shows that the equity holders of credit unions receive the tax saving as unusual returns. These unusual returns do not show up as relatively high dividends, however. Instead, they occur as unusually large retained earnings accumulated as net worth in their credit unions. The shareholders' extra income reinvested in the credit union provides new capital that allows the credit union to grow faster than other institutions."

4 "Research on GSEs (Government Sponsored Enterprises) and credit union research support the view that the principal incidence of tax exemption is an increase in the total assets and equity ratio of the credit union sector."
} 
Assim, se a isenção fiscal aumenta o total do ativo e, também, a relação entre o patrimônio líquido e o ativo total, ou seja, aumenta a participação do capital próprio, é de se supor que a isenção fiscal acarrete uma redução do capital de terceiros na composição da estrutura de capital.

Portanto, este estudo verifica a tese de que os incentivos fiscais influenciam a estrutura de capital e a rentabilidade das companhias abertas brasileiras não financeiras.

Esse argumento pode ser corroborado pela teoria sobre estrutura de capital proposta por Modigliani \& Miller (1958) a qual afirma que o ganho devido à alavancagem é fruto do produto entre a Taxa de Imposto de Renda da Empresa e o Valor de Mercado da Dívida. Isso implica que quanto menor for a taxa de imposto de renda da empresa, menor será o ganho da alavancagem e, conseqüentemente, menor o incentivo para o endividamento. No caso de empresas que usufruam de incentivos fiscais, a taxa de imposto de renda tenderá a ser menor e, dessa forma, o incentivo para o endividamento nessas empresas será menor ocasionando uma estrutura de capital diferente daquelas empresas que não gozam de incentivos fiscais.

Adicionalmente, o incentivo fiscal pode ser visto como uma fonte de financiamento para a empresa na medida em que, deixando de recolher os impostos, pode aplicar esses recursos em outros ativos ou processos ligados à sua atividade principal com o objetivo de obter um melhor desempenho econômico e financeiro.

De acordo com Pêgas (2006), os tributos estão refletidos em todas as demonstrações financeiras, principalmente na Demonstração do Resultado do Exercício (DRE), possibilitando que a empresa tenha conhecimento de como e quanto cada etapa representou, podendo tomar decisões gerenciais seguras, a fim de melhorar o seu desempenho. Da mesma forma, os incentivos fiscais, minimizando a carga tributária, devem estar refletidos nos resultados e serem utilizados como um instrumento de gestão para melhorar o desempenho empresarial de forma geral. É oportuno ressaltar que se considerarem os incentivos fiscais não se pode fazer essa afirmação, em virtude de que, devido à multiplicidade de opção de sua contabilização vigente até 31/12/2007, seus valores poderiam ou não estar refletidos nas demonstrações financeiras. 
Vale ressaltar, ainda, que, de acordo com Vasconcelos e Brito (2004, p. 57-58), a medição da vantagem competitiva começa, sempre, com a medição do desempenho empresarial, que tem múltiplas dimensões e não há consenso sobre o modo como medi-lo. Porém, tradicionalmente, a variável retorno sobre ativos é escolhida como medida de mensuração do desempenho econômico, dentre outras.

A Figura 3 apresenta uma síntese da ligação entre os incentivos fiscais, a estrutura de capital e a rentabilidade.

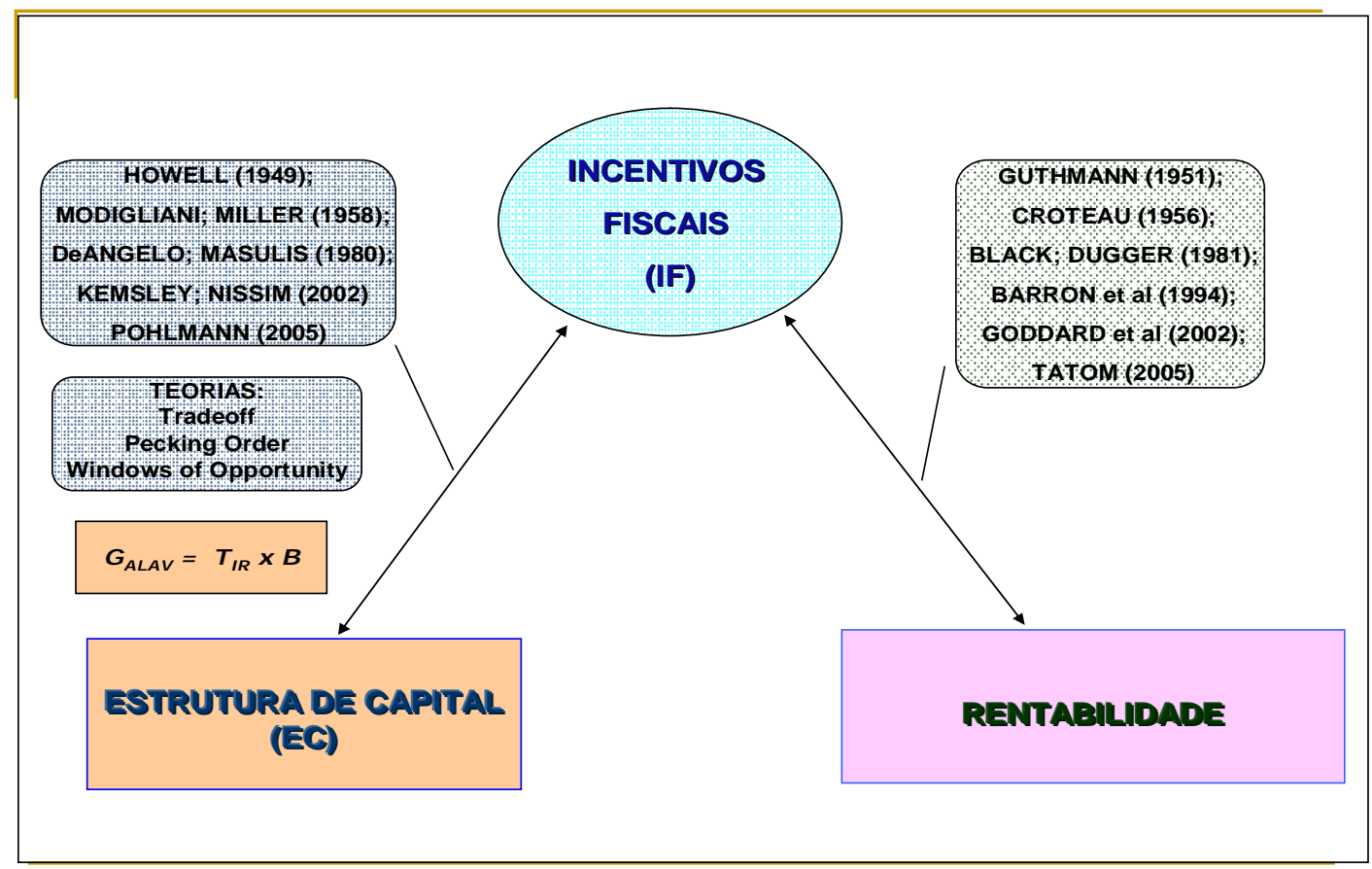

Figura 3 - Síntese da ligação entre os incentivos fiscais, a estrutura de capital e a rentabilidade

Por outro lado, não se pode afirmar que todas as empresas que façam uso de incentivo fiscal, seja por motivo de decisão pelo local de instalação, decisão de expansão ou por uma decisão de entrada no mercado exterior (exportação), obtenham, efetivamente, melhor desempenho em relação àquelas que não se beneficiam. Outras variáveis de natureza interna (competência de gestão, por exemplo) e/ou externa (econômicas, políticas) podem interferir nesse processo. Todavia, não se pode ignorar que os incentivos fiscais podem representar um fator a mais de contribuição para melhorar o desempenho das empresas, mesmo porque essa é uma finalidade 
subjacente do governo, ao implementar essa medida, e também da empresa, na decisão por se beneficiar desse instrumento governamental. Mas, a questão é: em qual medida?

\subsection{Questão de pesquisa}

Segundo Köche (1999), um problema (ou questão) de pesquisa é um enunciado interrogativo que questiona sobre a possível relação entre duas ou mais variáveis, ligadas ao objeto de investigação e passível de testagem ou observação empírica. Tal enunciado é o fio condutor da pesquisa, pois com base nele é possível definir conteúdos, elaborar objetivos, definir variáveis, identificar os procedimentos de análise, formular o instrumento de coleta etc.

A questão de estudo que emerge do cenário apresentado é: os incentivos fiscais influenciam a estrutura de capital e a rentabilidade das companhias abertas brasileiras não financeiras? A Figura 4 exibe a estrutura da referida questão de estudo.

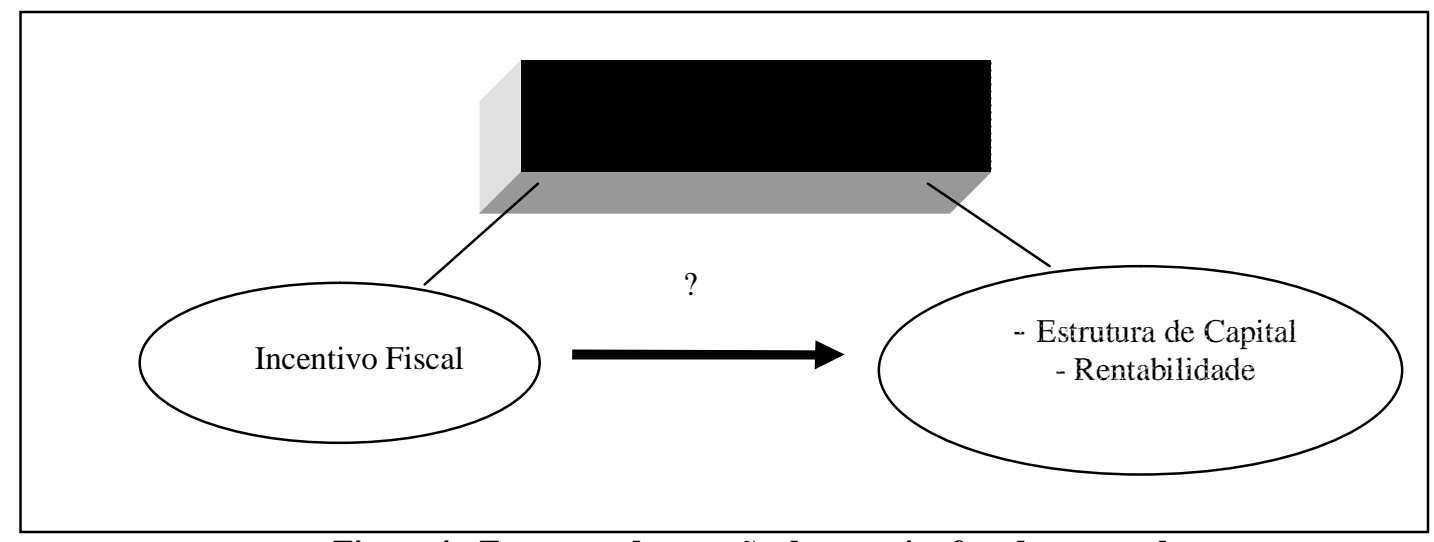

Figura 4 - Estrutura da questão de pesquisa focada no estudo

\subsection{Hipóteses de Pesquisa}

De acordo com Köche (1999, p. 108), hipótese "é a explicação, condição ou princípio, em forma de proposição declarativa e afirmativa, que relaciona entre si as variáveis que dizem respeito a um determinado fenômeno ou problema." O autor acrescenta que a hipótese consiste na solução provisória proposta como sugestão no processo de investigação de um 
problema extraído da questão de pesquisa levantada. Para Levin e Fox (2004, p. 219-220), o objetivo da maioria dos pesquisadores é testar hipóteses.

Neste estudo, consideram-se as seguintes hipóteses de pesquisa:

$\mathbf{H}_{1}$ : Os incentivos fiscais afetam a estrutura de capital das companhias abertas brasileiras não financeiras, reduzindo o seu nível de endividamento.

$\mathbf{H}_{2}$ : Os incentivos fiscais afetam a rentabilidade das companhias abertas brasileiras não financeiras, aumentando o retorno do ativo e do patrimônio líquido.

\section{$1.4 \quad$ Objetivos}

\subsubsection{Objetivo geral}

Segundo Santos (1999), o objetivo geral deve expressar, claramente, aquilo que o pesquisador pretende conseguir com sua investigação. Ele delimita e direciona os raciocínios a serem desenvolvidos. O verbo que o define deve indicar uma ação intelectual mensurável cujo produto possa ser mensurado. O objetivo geral que se pretendeu alcançar com a realização deste estudo foi o de avaliar os efeitos dos incentivos fiscais sobre a estrutura de capital e a rentabilidade das companhias abertas brasileiras não financeiras.

\subsubsection{Objetivos específicos}

A fim de atingir o objetivo geral proposto na introdução deste estudo, algumas etapas necessitam ser cumpridas, as quais constituem os objetivos específicos. (RICHARDSON, 1999). Para fins deste estudo, foram considerados os seguintes objetivos específicos:

Objetivo 1: Descrever as companhias abertas brasileiras de acordo com as variáveis de controle: classe das ações negociadas, setor de atuação, nível de tributação, tempo de operação e crescimento médio anual. 
Objetivo 2: Identificar as diferenças na estrutura de capital e/ou rentabilidade entre companhias abertas brasileiras não financeiras que usufruem de incentivos fiscais quando comparadas com empresas que não usufruem de tais incentivos.

Objetivo 3: Elaborar um modelo que relacione os incentivos fiscais, a estrutura de capital, a rentabilidade e as variáveis de controle das companhias abertas brasileiras não financeiras por meio do modelo genérico General Linear Model - Multivariate Analysis of Variance. (GLM.MANOVA).

Objetivo 4: Investigar o efeito do incentivo fiscal sobre a estrutura de capital e a rentabilidade em companhias abertas brasileiras não financeiras.

\subsection{Justificativa e relevância}

A importância do estudo dos incentivos fiscais é revelada por Borges (2007, p. 8), quando afirma que, até o momento, são conhecidos apenas estudos fragmentários e parciais sobre os incentivos e que a literatura nacional ressente-se da inexistência de um estudo elaborado com perspectiva de maior amplitude.

No Brasil, a relevância relativa dos recursos envolvidos na concessão de subsídios tributários pode ser evidenciada, por exemplo, por meio da renúncia fiscal de tributos administrados pela Secretaria da Receita Federal do Brasil, incluídos os valores de renúncia efetiva relativas às contribuições previdenciárias, no ano de 2006, que chega ao montante de R \$ 53,99 bilhões, valor superior aos gastos federais com Saneamento, Desporto e Lazer, Habitação, Energia, Comunicações, Urbanismo, Gestão Ambiental, Indústria, Relações Exteriores, Comércio e Serviços, Organização Agrária, Essencial à Justiça, Ciência e Tecnologia, Segurança Pública, Legislativa, Agricultura e Administração, que juntas somaram R \$ 53,94 bilhões em 2006. (BRASIL, 2007, p. 75).

Relativamente aos EUA, Tatom (2005, p. 1) afirma que, em virtude das isenções fiscais, as cooperativas de crédito estão crescendo rapidamente e aumentando a perda fiscal do Tesouro Federal. Ele estima que a renúncia fiscal durante um período de cinco anos, 2004-2008, seja 
de US \$12,6 bilhões. Estendido para o período do orçamento federal típico de dez anos, o prejuízo fiscal alcança US \$31,3 bilhões. Esse prejuízo fiscal é substancialmente mais elevado do que as estimativas elaboradas pelos órgãos do governo, incluindo o Instituto de Orçamento e Gestão ou Escritório de Orçamento do Congresso.

A Figura 5 apresenta uma comparação do total das receitas renunciadas com as despesas com saúde, assistência social e educação no Brasil.

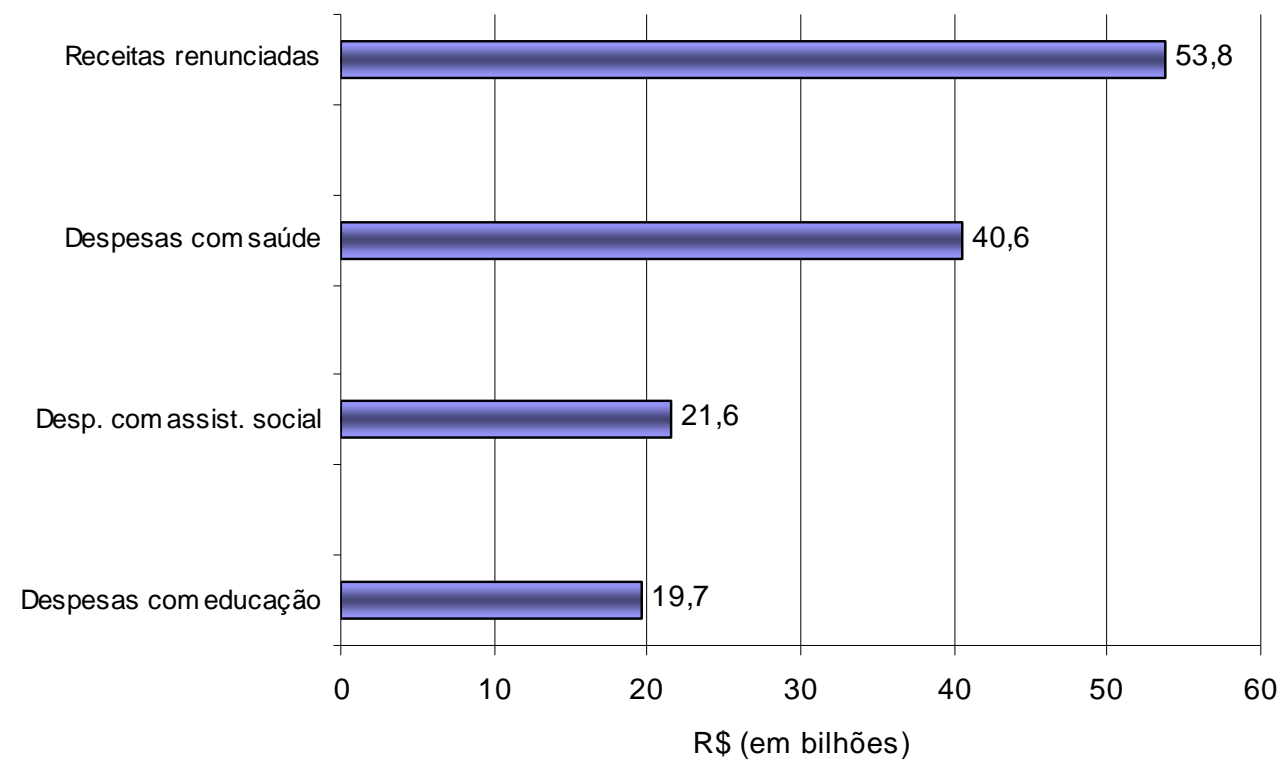

Figura 5 - Total renunciado de receitas e despesas de diversas funções de governo no ano de 2006 Fonte: BRASIL - TCU, 2007

De acordo com as projeções da Receita Federal do Brasil, em 2007, o volume de tributos e contribuições previdenciárias que o governo deixará de arrecadar passará dos $\mathrm{R}$ \$ 65,5 bilhões. Em quatro anos, de 2004 a 2007 (até dezembro), o crescimento da renúncia fiscal chegará a pelo menos $89 \%$, aproximadamente três vezes a inflação do período. O Imposto de Renda da Pessoa Jurídica (IRPJ) é o tributo com o maior percentual de incentivo, representando uma renúncia fiscal de, aproximadamente, $29 \%$ da sua receita no ano de 2007 , equivalendo a pouco mais de R\$ 15 bilhões. Em seguida, vêm a Contribuição para Financiamento da Seguridade Social (COFINS), com mais de R 13 bilhões de renúncia, ou 25\% da receita total, e o Imposto sobre Produtos Industrializados (IPI), com mais R \$ 8,3 bilhões (16\% da receita total). Os benefícios são concentrados na região Sudeste $(45,86 \%)$, em que é arrecadado o maior volume de impostos. Proporcionalmente à arrecadação, a região mais 
beneficiada é a Norte, por causa dos incentivos à Zona Franca de Manaus - ZFM, que vigoram há 40 anos (FOLHA DE S.PAULO, 2007).

A tudo isso se acresça, ainda, o fato de que a arrecadação de tributos no Brasil é altamente sofisticada, complexa e polêmica e, como em muitas outras áreas do conhecimento, não consensual, havendo grande demanda por estudos que tragam melhores informações e esclarecimentos.

Nesse contexto, entende-se que os tributos, que impactam, de forma relevante, no resultado contábil e no patrimônio das empresas e, consequentemente, os incentivos fiscais, caracterizam-se como um importante, recomendável e necessário campo de pesquisa nas áreas de Contabilidade e de Gestão.

Adicionalmente, ressalte-se que, no Brasil, não se tem conhecimento de pesquisas especificamente voltadas à apuração dos efeitos dos incentivos fiscais no desempenho econômico-financeiro das organizações empresariais nos moldes do foco deste estudo, sob a ótica microeconômica, ou seja, estuda-se o efeito na unidade empresa.

Todavia, tem-se conhecimento de estudos desenvolvidos tendo como uma das variáveis a tributação, mas, não, especificamente, a variável incentivo fiscal. Citam-se como exemplos de estudos sobre tributação que não incluem a variável incentivos fiscais os seguintes: Costa, (1963); Neviani, (1971); Schoueri, (1987); Poli e Procianoy, (1993); Christians et al. (1997); Siqueira et al. (2001); Bertolucci e Nascimento (2006); Loyolla e Ferreira (2002); Sayeg (2003); Anuatti-Neto et al. (2005); Pohlmann (2005); Lameira et al. (2005); Siqueira e Ramos (2005); Grzybovski e Hahn (2006); Brami-Celentano e Carvalho (2007); Corrar et al. (2007); Santos e Ferreira Filho (2007); Freitas et al. (2007) e Machado (2007).

Ademais, tem-se conhecimento de estudos no Brasil sobre o impacto dos incentivos fiscais, mas esses realizados sob o enfoque macroeconômico visando a avaliar o impacto desses incentivos na economia regional ou setorial, a exemplo de Lacombe (1969); Cardoso (1971); Santos e Candiota (1974); Roesch (1984); Roesch (1990); Berman et al. (1997); Limberg et al. (1997); Ponciano e Campos (2003); Aguiar e Monteiro (2005); Noronha (2005); Vazquez (2005); Davies (2006); Paes e Bugarin (2006); Ugá e Santos (2006); Prado Filho e Sobreira (2007); Dain (2007) e Guarnieri (2008). 
Em suma, justifica-se que o estudo dos incentivos fiscais é de grande relevância para o meio acadêmico, empresarial, a sociedade e a administração pública dados os possíveis reflexos, positivos e/ou negativos, que tal instrumento pode ocasionar às partes evolvidas, ou seja: sociedade - empresa - governo. Esse entendimento é corroborado por Forte (2007, p. 18):

O estudo do comportamento das empresas como agentes microeconômicos e sua tomada de decisão é fundamental para a geração de políticas econômicas eficientes no nível macroeconômico e um elemento de competitividade de empresas no nível microeconômico.

Scharlack (2008) afirma que as formas de economia fiscal envolvem projetos de alta complexidade e avançada tecnologia fiscal, financeira e societária. Ele explica que, no planejamento empresarial, inúmeras decisões são tomadas com vistas à realização do lucro, tais como: a escolha do setor, do produto, da matéria-prima, do fornecedor, da região, do mercado consumidor, as decisões sobre o financiamento da planta industrial e da produção (capital próprio ou de terceiros?), a opção pela forma societária. Nesse amplo contexto, a tributação e, por conseqüência, os incentivos fiscais exercem um papel importantíssimo.

Scharlack (2008) explica que é vantajoso o aproveitamento de incentivos, sistemáticas e programas oficiais para nortear o planejamento empresarial, fazendo-se, assim, economia segura de tributos, a otimização de recursos e o conseqüente incremento da competitividade. Ele alerta que o risco de se reduzir o gasto tributário mediante a adoção de um programa oficial é, sem dúvida, infinitamente menor do que aquele que se administra quando se procede a um planejamento tributário. Essa diferença é relevante quando se pretende reduzir custos e ganhar competitividade em disputas licitatórias ou mesmo em novos mercados, em que não se mostrem claras as variáveis balizadoras do risco empresarial. Scharlack (2008) orienta que, ao se adotar um ou mais incentivos oficiais, reduz-se o custo e aumenta-se o retorno do investimento, tudo sem o correspondente incremento do risco tributário e, ainda, em prol do interesse público.

A relevância do estudo do efeito dos incentivos fiscais sobre a estrutura de capital e a rentabilidade das companhias abertas brasileiras não financeiras caracteriza-se pelo seguinte:

a) esse efeito é desconhecido e, assim, o seu conhecimento propicia agregação de esclarecimentos à teoria sobre os tributos, mais especificamente, sobre os incentivos fiscais. 
b) com esse conhecimento as empresas terão mais informações para decidirem sobre os seus objetivos estratégicos, como, por exemplo, localização geográfica;

c) na formulação de políticas econômicas, o conhecimento desse efeito possibilita ao governo avaliar a decisão de continuidade ou não de concessão dos incentivos fiscais.

\subsection{Contribuições do estudo}

Espera-se que o estudo contribua com:

1) A apresentação da organização do desenvolvimento teórico do estudo;

2) A descrição do perfil das companhias abertas brasileiras não financeiras de acordo com o usufruto de incentivos fiscais;

3) Um modelo que relaciona incentivo fiscal, estrutura de capital, rentabilidade e variáveis de controle baseado no procedimento estatístico denominado General Linear Model;

4) Uma discussão do efeito do incentivo fiscal sobre a estrutura de capital e rentabilidade de companhias abertas brasileiras não financeiras.

\subsection{Inovações da tese}

Segundo Sampieri et al. (2006, p. 27), “As boas idéias de pesquisa "não são necessariamente novas', mas sim inovadoras.” É necessária, muitas vezes, a adaptação de projetos derivados de pesquisas efetuadas em contextos diferentes ou buscar novos caminhos.

Diversos estudos realizados sobre estrutura de capital verificaram a influência de diversas variáveis sobre o endividamento das empresas, tais como: tamanho da empresa (TITMAN; WESSELS, 1988), ativo operacional líquido (KEMSLEY; NISSIM, 2002), nível de tributação (POHLMANN, 2005). A inovação trazida por este estudo, relativamente à estrutura de capital, consiste na verificação da influência da variável incentivos fiscais na estrutura de capital, mais especificamente sobre o endividamento das empresas.

Estudos realizados nos EUA verificaram a influência dos incentivos fiscais na rentabilidade das instituições financeiras, tais como: Guthmann (1951), Croteau (1956), Hannan (2002) e Tatom (2005). A inovação trazida por este estudo, relativamente à rentabilidade, consiste na 
verificação da influência dos incentivos fiscais na rentabilidade de empresas brasileiras não financeiras.

As Figuras 6 e 7 evidenciam as inovações trazidas por este estudo.

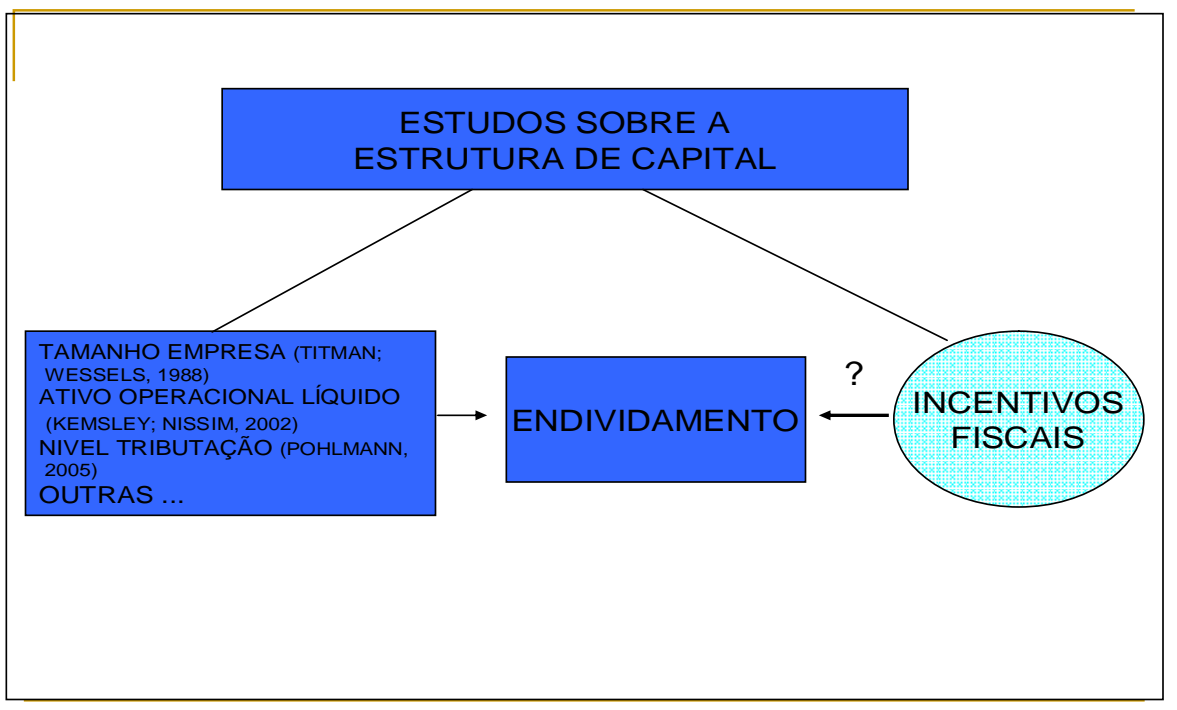

Figura 6 - Inovação da tese para os estudos sobre a estrutura de capital

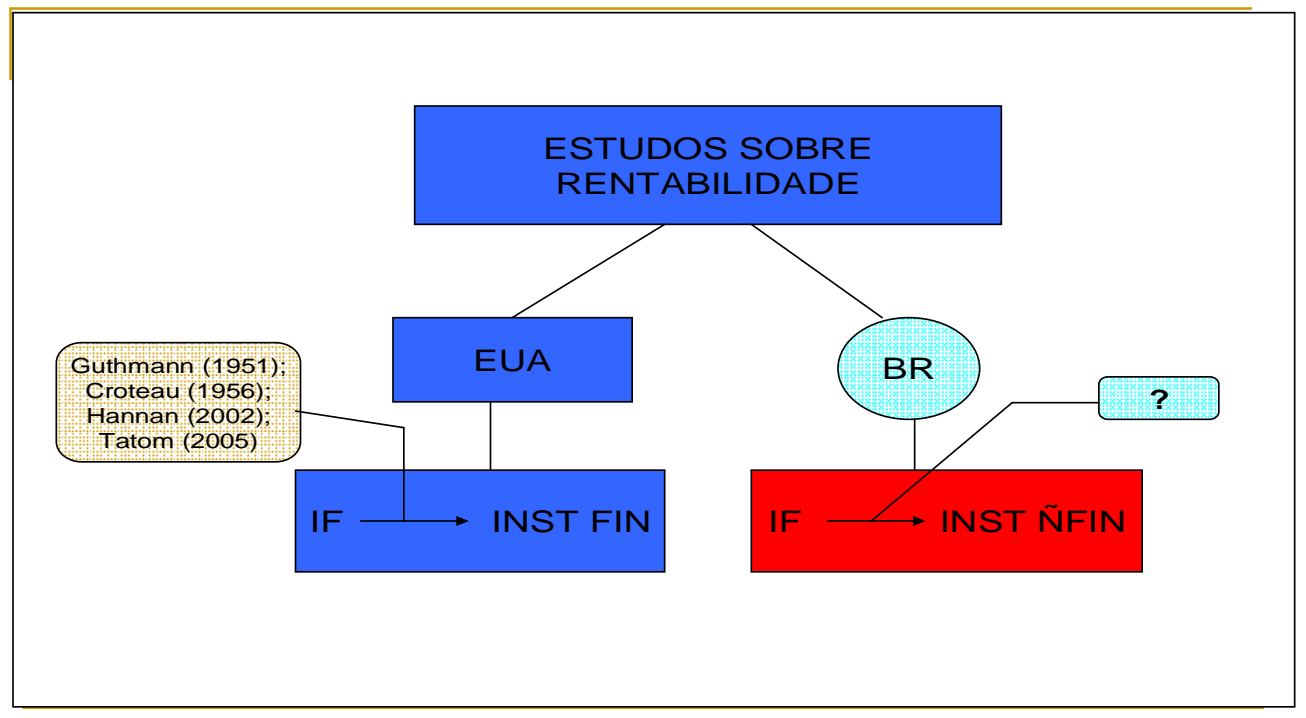

Figura 7 - Inovação da tese para os estudos sobre rentabilidade 


\subsection{Estrutura do trabalho}

O presente estudo está estruturado em 6 capítulos. O primeiro trata dessa introdução. No capítulo 2, é apresentado o referencial teórico que aborda a conceituação de incentivos fiscais; as normas de contabilidade (nacionais e internacionais) relativas ao seu reconhecimento e registro; um panorama da pesquisa atual sobre os incentivos fiscais no Brasil e no exterior e, por último, abordam-se os conceitos de estrutura de capital e suas principais teorias e, ainda, as medidas para avaliação de desempenho. No capítulo 3, apresenta-se a metodologia empregada no estudo e no capítulo 4, mostram-se as análises e discussões dos resultados da pesquisa realizada. No capítulo 5, são feitas as discussões dos resultados apurados em confrontação com a teoria. Por fim, no capítulo 6, têm-se as conclusões, limitações e sugestões para futuras pesquisas do tema na área de contabilidade. 


\section{REFERENCIAL TEÓRICO}

\subsection{Incentivos fiscais}

\subsubsection{Definição de incentivos fiscais e suas finalidades}

Incentivos fiscais são renúncias de receitas públicas que beneficiam os contribuintes. Caracterizam-se por instrumentos baseados em desoneração tributária, em que o Estado dispensa tratamento tributário diferenciado ao contribuinte, cujo objetivo é (MELO, 2007, p. 140):

a) promover o desenvolvimento econômico regional, fomentando determinados setores produtivos ou regiões;

b) reduzir as desigualdades sociais nacionais e regionais;

c) aumentar o saldo da balança comercial;

d) colocar os produtos de fabricação nacional no mercado externo;

e) desenvolver o parque industrial nacional;

f) gerar empregos.

A implementação da política de incentivos fiscais, no Brasil, passou a ter destaque a partir dos anos 1960, quando, então, diversas leis foram editadas nas diversas esferas de governo dispondo sobre incentivos fiscais.

Pires (2007, p. 35) acrescenta que "A concessão de incentivos fiscais deve ser entendida como instrumento de desenvolvimento e de melhoria da qualidade de vida da população, por meio da criação de empregos, da geração e redistribuição da renda, [...].”

Os incentivos fiscais não visam a privilegiar o contribuinte, mas promover ações ou comportamentos em prol da sociedade. Fazem parte desse gênero:
a) as isenções;
b) as reduções de alíquota e de base de cálculo;
c) a alíquota zero; 
d) as subvenções;

e) os créditos presumidos;

f) os subsídios;

g) o diferimento.

Assim, uma norma jurídica que não exija contrapartida diretamente vinculada à promoção do bem comum não institui incentivo fiscal, mas, sim, benefício fiscal, gerando privilégio diretamente dirigido ao contribuinte. (DINIZ; RIBEIRO, 2004; DINIZ; FORTES, 2007, p. 274-291; ELALI, 2007, p. 53; RODRIGUES, 2007, p. 301).

Ressalte-se que, embora os incentivos fiscais não objetivem o privilégio do contribuinte, ele tem como conseqüência, inicialmente, o seu benefício, ocasionando, assim, efeitos de desigualdade na concorrência com outros contribuintes que não usufruem dos referidos incentivos.

\subsubsection{Renúncia fiscal, benefícios fiscais e incentivos fiscais.}

Comumente, tem-se a utilização dos termos Renúncia Fiscal, Benefícios Fiscais e Incentivos Fiscais como sinônimos. Todavia, apresentam algumas diferenciações em termos jurídicos, ainda que não resultem em consenso.

No plano econômico, os conceitos de benefícios fiscais, incentivos e isenção são amplos, abrangendo qualquer mecanismo de exoneração ou de diminuição da carga tributária, que produza, nesse plano, o mesmo efeito das isenções (TORRES, 2007, p. 335). Conquanto os incentivos fiscais façam parte da Constituição Federal desde 1934, até hoje, porém, não se encontra no ordenamento brasileiro uma classificação ou sequer uma designação, das hipóteses de incentivos. (PIRES, 2007, p. 24-25), ou seja, não existe um consenso conceitual sobre o entendimento desses termos.

Contribuindo com esse desentendimento conceitual, Diniz e Fortes (2007, p. 271-272) observam que nem mesmo o Superior Tribunal de Justiça - STJ dispensa o tratamento esperado à conceituação da expressão incentivo fiscal, empregando, com freqüência, nos mais variados acórdãos, os termos: incentivo, incentivo fiscal, benefício fiscal e isenção como sinônimos. Nesse sentido, Diniz e Ribeiro (2004) afirmam que são utilizados indistintamente 
alguns signos, como subsídio, isenção, crédito presumido, manutenção de crédito, ressarcimento, redução de alíquota ou base de cálculo, alíquota zero, dilação de prazo, parcelamento, anistia, remissão etc., para se reportar aos gêneros benefício fiscal e incentivo fiscal.

Tendo em vista a imprecisão de conceitos acerca das espécies e das formas dos incentivos, a sua regulamentação oferece enorme dificuldade, o que, no entanto, tratando-se de tópico de intensa importância para a saúde econômica e disciplina política, não deveria estar regulado de forma tão esparsa e pouco objetiva. (PIRES, 2007, p. 34).

A falta de uniformidade nas denominações aos diferentes institutos de estímulos tributários pode ser observada, por exemplo, quando Rodrigues (2007, p. 321) explica que os incentivos fiscais oferecidos pelos Estados são semelhantes e, assim, o benefício perde o poder de estimular a localização da produção em determinado Estado da Federação. Esclarece o autor, que o benefício fiscal deixa de ser um incentivo, tornando-se mera redução de imposto.

De outra forma, Diniz e Fortes (2007, p. 274-291) orientam que os incentivos fiscais buscam obter resultados de natureza extrafiscal ao longo do tempo, em direção ao bem comum, exigindo uma contrapartida por parte do contribuinte, enquanto os benefícios fiscais são privilégios outorgados pelo Estado a determinados contribuintes, que abrangem fatos geradores e obrigações tributárias já ocorridas e consolidadas no tempo e não exigem vinculação a qualquer contraprestação. Assim, os benefícios fiscais, objetivam, unicamente, o benefício dos próprios contribuintes.

Nesse sentido, o Poder Público estabelece situações desonerativas de tributos, mediante a concessão de benefícios fiscais com o objetivo de estimular o contribuinte à adoção de determinados comportamentos, tendo como subjacente o propósito governamental à realização de diversificados interesses públicos. (MELO, 2007, p. 229).

Nos parágrafos anteriores, percebe-se que, para Rodrigues (2007), incentivos fiscais e benefícios fiscais representam situações desonerativas de imposto e estão no mesmo plano, ou seja, têm o mesmo significado, representam o mesmo instituto jurídico, tanto é que, na sua exposição, o termo incentivos fiscais é substituído por benefícios fiscais. Já para Diniz e Fortes (2007) incentivo fiscal é um instituto que vincula o contribuinte a determinadas 
obrigações, objetiva o bem comum e seus resultados serão gerados no futuro, enquanto benefícios fiscais não vinculam o contribuinte a nenhuma obrigação, beneficia somente o próprio contribuinte e têm como objetivo resolver uma situação atual decorrente de fatos geradores ocorridos no passado. E, por fim, para Melo (2007), os benefícios fiscais são um instituto de indução de comportamento com geração de resultados futuros, ou seja, o que é incentivo fiscal para Diniz e Fortes, é benefício fiscal para Melo.

Outro exemplo de não uniformidade na denominação dos diferentes estímulos tributários pode ser observado na exposição de Rodrigues (2007, p. 301), na qual explica que os incentivos fiscais são concedidos mediante isenção total ou parcial do tributo, para atingir determinados objetivos, definidos em lei, que estabelecerá as diretrizes a serem cumpridas para que os incentivos fiscais possam ser usufruídos. Por outro lado, Diniz e Fortes (2007, p. 275) afirmam que existe um diferencial entre incentivo fiscal e isenção: enquanto no incentivo fiscal o contribuinte se obriga perante o Estado, como condição formal para a sua fruição, na isenção inexiste diretamente o dever de retorno, bastando a subsunção do contribuinte à norma isentiva.

Observa-se, pelo exposto, que Rodrigues entende a isenção como uma espécie, do gênero incentivo fiscal, diferentemente de Diniz e Fortes, que trata os dois institutos como gêneros distintos.

Em suma, de acordo com Diniz e Fortes (2007, p. 297) as discussões jurídicas, envolvendo incentivos fiscais, encontram-se longe de estar pacificadas, em decorrência até mesmo da crescente complexidade das relações intersubjetivas, demandando, cada vez mais, a observância do rigorismo conceitual e da primazia do alcance dos fins sociais.

De forma geral, o que há de comum entre benefício fiscal e incentivo fiscal é que ambos pertencem à matéria tributária e atuam no sentido de atenuar ou eliminar os efeitos da tributação. A diferença é que o benefício é concedido para resolver resultados danosos passados enquanto o incentivo objetiva criar resultados positivos futuros. Como exemplo de benefícios, têm-se a anistia e o parcelamento e como exemplo de incentivos, têm-se a isenção e a redução da base de cálculo. 
A Figura 8 resume e explicita as relações conceituais entre Incentivo Fiscal, Benefício Fiscal e Renúncia Fiscal baseado, nos conceitos anteriormente expostos.

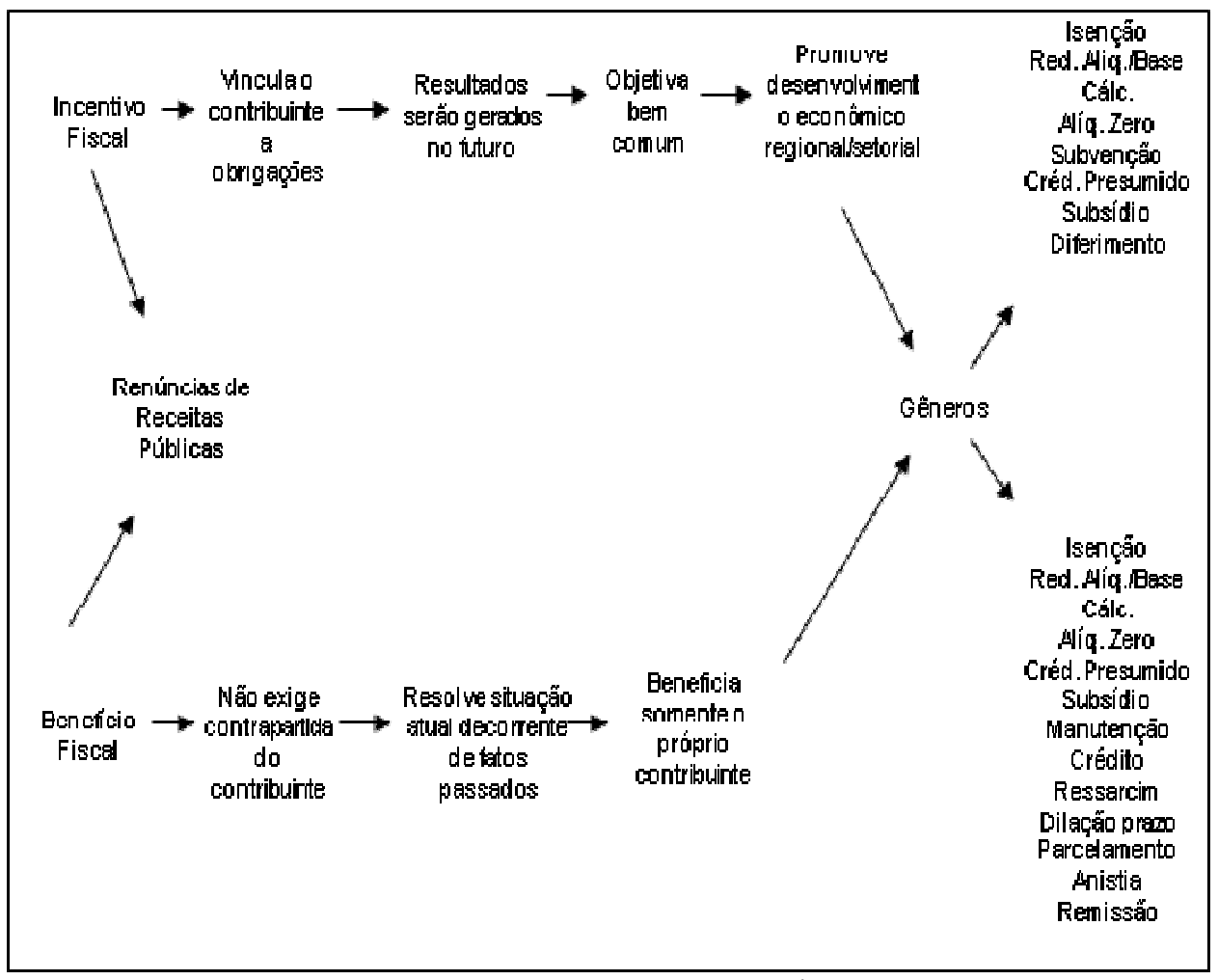

Figura 8 - Incentivos fiscais e benefícios fiscais

Em vista do exposto verifica-se que, quanto à forma jurídica, existem diferentes institutos legais, diferentes abordagens (jurídica, econômica, contábil) e conceitos, diferentes pontos de vista e diferentes instrumentos para os incentivos fiscais, não havendo, assim, um consenso a respeito do assunto. Considerando a essência econômica, os incentivos fiscais visam a promover um efeito positivo sobre o patrimônio ou a renda de um ou de um grupo de contribuintes. Isso permite adotar uma denominação única e construir as hipóteses deste trabalho.

\subsubsection{Classificação dos incentivos fiscais}

Os incentivos fiscais podem ser classificados levando-se em consideração: 1) as características das principais espécies; 2) os regimes jurídicos e 3) a finalidade, segundo podese observar na literatura apresentada a seguir: 


\subsubsection{Quanto às características das principais espécies}

Pires (2007, p. 19-20) classifica os incentivos fiscais, segundo as características das principais espécies, em duas categorias: aqueles decorrentes da despesa pública e os decorrentes da receita pública.

Como exemplos de incentivos atuantes sobre a despesa pública têm-se: subvenção, crédito presumido e subsídio. As subvenções, segundo Carvalhosa (1997, p. 603), "são ajudas ou auxílios pecuniários, concedidos pelo Estado, nos termos da legislação específica, em favor de instituições que prestam serviços ou realizam obras de interesse público.” Pires (2007, p. 22) orienta que o crédito presumido pode tratar-se ora de um subsídio, de uma subvenção ou de uma mera redução da base de cálculo, operando, tradicionalmente, no campo dos impostos não-cumulativos. No caso do subsídio, o autor afirma que sua utilização visa a reduzir as desigualdades sociais regionais e incentivar as exportações, compreendendo "toda ajuda oficial de governo, seja de natureza comercial, financeira, cambial ou fiscal, com o fim de estimular a produtividade de indústrias instaladas no país."

Os incentivos sobre a receita pública podem ser exemplificados em: isenção; diferimento; remissão e anistia. A isenção, conforme já exposto, é explicada por duas correntes ora como forma de incidência e ora como forma de não-incidência legalmente qualificada. No primeiro caso, há o surgimento da obrigação tributária e a posterior dispensa legal do pagamento do tributo e, no segundo caso, não ocorre o efeito do nascimento da obrigação tributária.

Pires (2007, p. 23) esclarece que, embora parte da doutrina considere o diferimento como uma subespécie da isenção, ele se caracteriza pelo deslocamento do momento de ocorrência do fato gerador do tributo para uma data futura. Caso, no futuro, a condição de fato não seja cumprida, a postergação do fato gerador torna-se inválida, provocando a anulação dos efeitos jurídicos provocados pelo diferimento do tributo. (SEIXAS FILHO, 1989, p. 37).

$\mathrm{Na}$ Figura 9, tem-se um resumo das classificações de incentivos fiscais segundo suas principais espécies anteriormente expostas. 


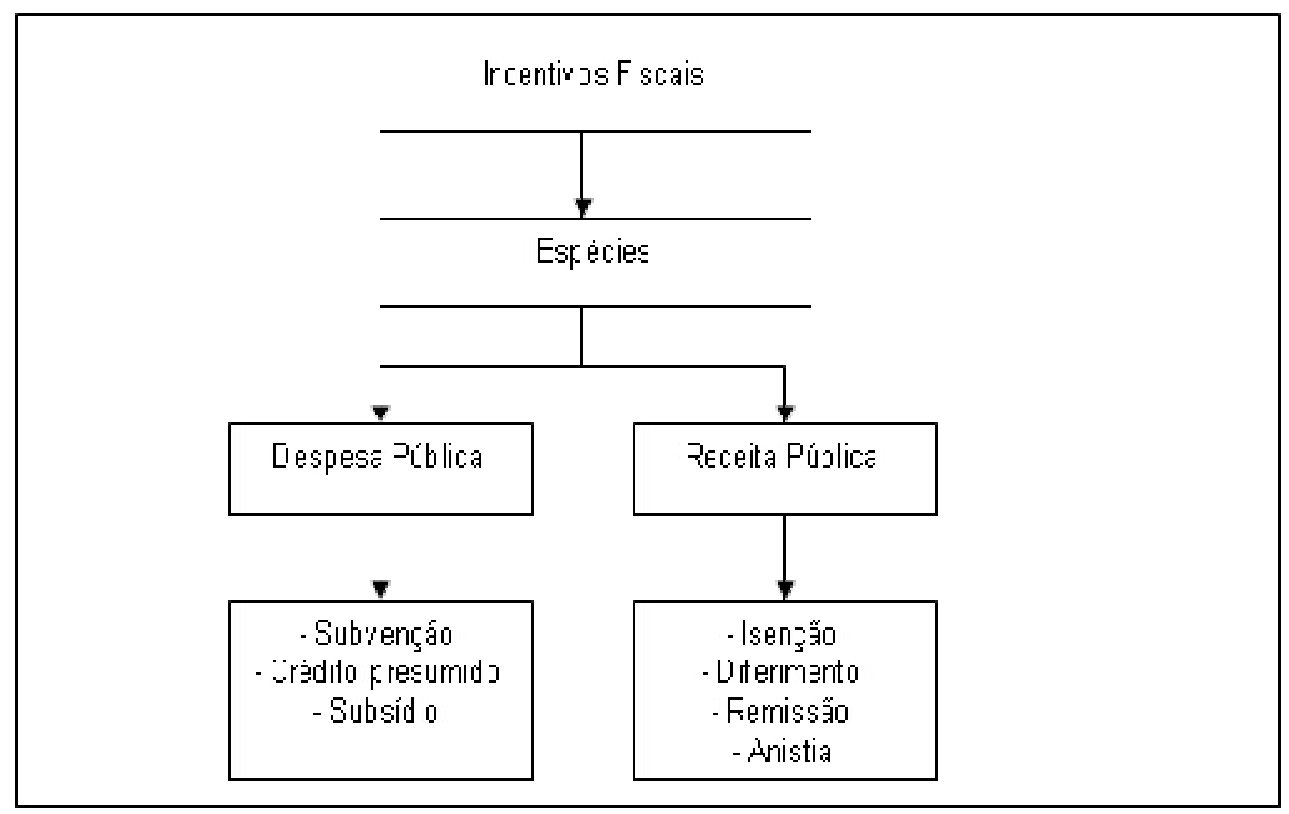

Figura 9 - Incentivos fiscais segundo suas principais espécies

Com relação à remissão e à anistia, conquanto não se tratem, rigorosamente, de redução de carga tributária, podem ser consideradas como instrumentos de estímulo ao desenvolvimento de certas atividades econômicas. Pires (2007, p. 24) afirma que a "remissão é simples ato de liberalidade do legislador, que desobriga o contribuinte do cumprimento da obrigação [...]" e, segundo Sabbag (2006, p. 250), a anistia exclui o crédito tributário, surgindo após o nascimento da obrigação tributária e antes do lançamento.

\subsubsection{Quanto aos regimes jurídicos}

A classificação para os estímulos tributários, considerando-se os regimes jurídicos do direito tributário e do direito financeiro, categoriza-os em incentivos tributários e incentivos financeiros.

Os incentivos tributários, denominados incentivos fiscais, atuam por via tributária, como por exemplo: a isenção, a alíquota zero e a redução de base de cálculo, enquanto os incentivos financeiros atuam pela via dos subsídios: facilidades creditícias e prêmios de exportação. Porém, existem alguns, como é o caso das subvenções, que embora sejam concretizadas por meio da tributação, configuram categorias jurídicas que pertencem ao domínio do direito financeiro, caracterizando-se, portanto, como espécie de incentivo financeiro. Dessa forma, não basta um determinado estímulo ser concretizado pela via do tributo para ser tratado como 
incentivo fiscal no sentido estritamente jurídico, o incentivo fiscal deve ser concretizado por meio de institutos próprios do direito tributário. (DINIZ; RIBEIRO, 2004).

Relativamente à subvenção, a Lei 4.320 de 1964, em seu artigo 12, § 3º, considera como tal as transferências destinadas a cobrir despesas de custeio das entidades beneficiadas, distinguindo-as em:

I - $\quad$ subvenções sociais, as quais se destinem as instituições públicas ou privadas de caráter assistencial ou cultural sem finalidade lucrativa;

II - subvenções econômicas, as que se destinem a empresas públicas ou privadas de caráter industrial, comercial, agrícola ou pastoril.

Borges (2007, p. 43) adverte que, para a fixação do regime jurídico da subvenção financeira, não cabe o recurso a conceitos e categorias econômicas. Economicamente, isenção e subvenção são tidas como categorias idênticas, porque produziriam os mesmos efeitos. Juridicamente, essa identidade não se verifica, porque há um critério de discriminação formal entre ambas, adotado e prestigiado pelo sistema. Essa equiparação entre subvenção e isenção, no plano econômico, decorreria do fato de que a isenção tem um custo equivalente ao de uma subvenção. Teoricamente, poder-se-ia substituir o sistema de isenções por um sistema de subvenções com a vantagem de oferecer o custo social decorrente desse último incentivo.

No caso da subvenção, a ocorrência da hipótese pressuporia, juridicamente, a extinção da relação tributária e, conseqüentemente, o retorno da receita pública ao ente subvencionado, pelo mecanismo da despesa pública. Essa circunstância, ao contrário, jamais se verifica nas hipóteses legais de isenção, que impedem o próprio surgimento da obrigação tributária. Essa diferenciação é fundamental porque, só ela, basta para fornecer ao intérprete critério seguro de distinção entre isenção e subvenção, identificável no confronto entre essas duas categorias jurídicas. O conceito de subvenção está sempre associado à idéia de auxilio, ajuda expressa normalmente em termos pecuniários. A subvenção pressupõe sempre o concurso de dinheiro ou outros bens estatais. (DINIZ; RIBEIRO, 2004).

No mesmo sentido, a Lei Complementar 101, de 04 de maio de 2000, explicita que os incentivos fiscais estão relacionados com a receita pública, ao contrário das subvenções que estão afetas à disciplina da despesa. Percebe-se, no seguinte trecho do artigo 14: “A concessão ou ampliação de incentivo ou benefício de natureza tributária da qual decorra renúncia de 
receita [...]”, que toda vez que o ente competente conceder um incentivo ou benefício fiscal estará abrindo mão de uma parcela de sua receita. A Figura 10 exibe o esquema de classificação dos Incentivos segundo o regime jurídico.

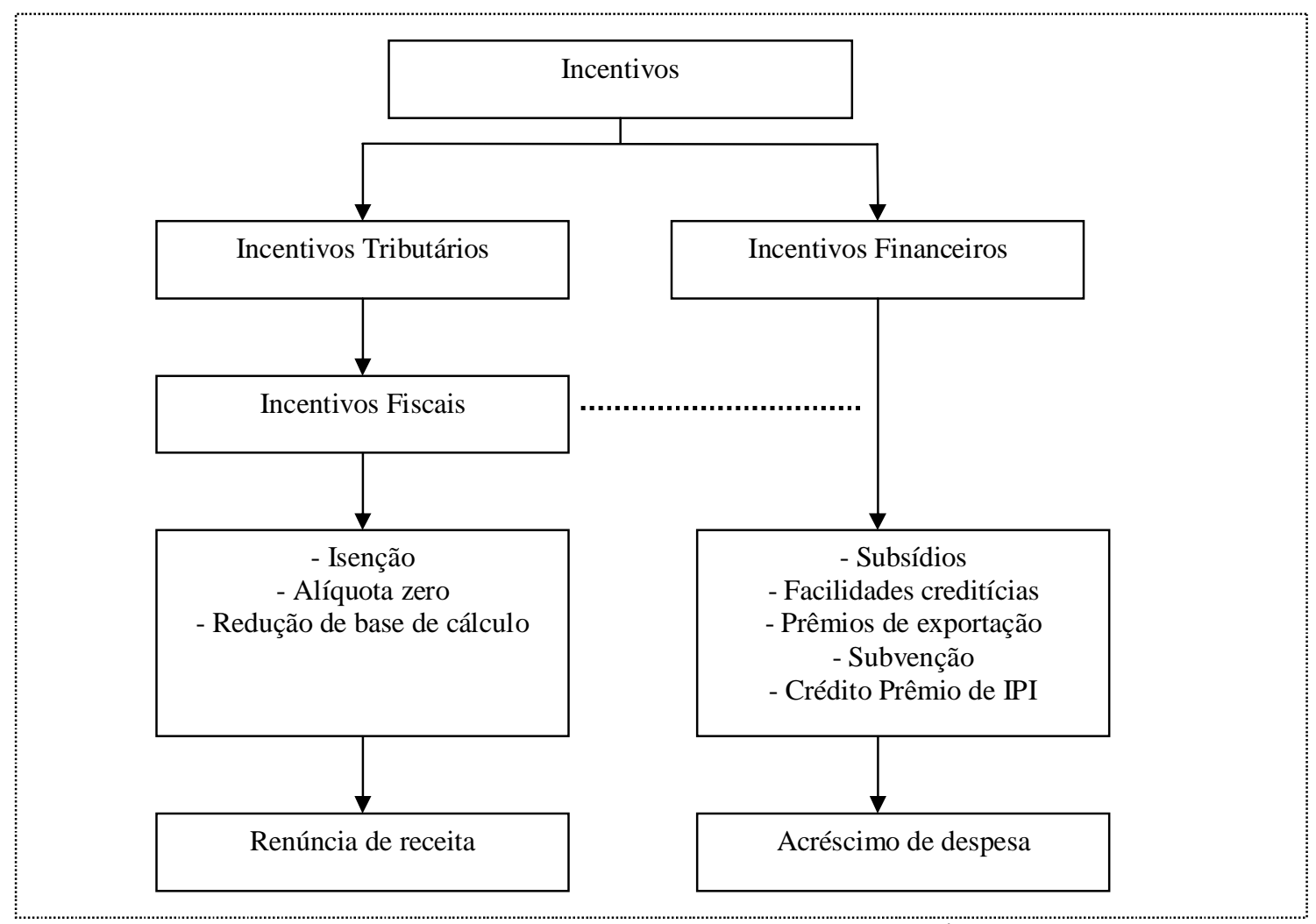

Figura 10 - Incentivos fiscais segundo o regime jurídico

Verifica-se, assim, que, se o estímulo concedido pelo Estado não implicar renúncia de receita, mas, sim, acréscimo de despesa, estar-se-á diante de um estímulo financeiro, como é o caso da subvenção. Configura-se a despesa precisamente pelo fato de o Estado não abdicar de uma fatia dos seus recursos, mas transferir, pelas formas mais diversas, valores que já ingressaram no cofre público.

É o que ocorre com o crédito-prêmio do IPI, uma vez que o Estado não deixa de arrecadar importâncias devidas a título de tributo, mas, sim, transferir, por meio do ressarcimento, valores resultantes da aplicação de determinadas alíquotas sobre o montante do produto exportado. Assim, o crédito-prêmio do IPI constitui espécie de estímulo financeiro, para reduzir o impacto tributário existente sobre a produção, visando a estimular as exportações. Mas como não penetra, para modificar ou mutilar, o terreno da regra-matriz de incidência, 
nem tampouco implica diminuição do montante da prestação tributária, é impróprio atribuirlhe a condição de espécie de incentivo fiscal. (DINIZ; RIBEIRO, 2004).

\subsubsection{Quanto à finalidade}

Quanto à finalidade, os incentivos fiscais podem ser classificados em três espécies (AUGUSTO, 2006; DINIZ; RIBEIRO, 2004):

a) incentivo fiscal global ou geral, que se caracteriza pelo objetivo de abarcar os interesses de toda a nação, uma variada gama de setores e regiões do país;

b) incentivo fiscal regional, por meio do qual o escopo é estimular a economia em determinada região do país, como ocorre com a Zona Franca de Manaus;

c) incentivo fiscal setorial, cuja área de atuação circunscreve-se a determinado segmento da economia, como é o caso do turismo, que foi estimulado por meio do Decreto-Lei 55, de 18 de novembro de 1966, artigo 24. Na Figura 11, tem-se a esquematização da classificação dos incentivos fiscais segundo a sua finalidade.

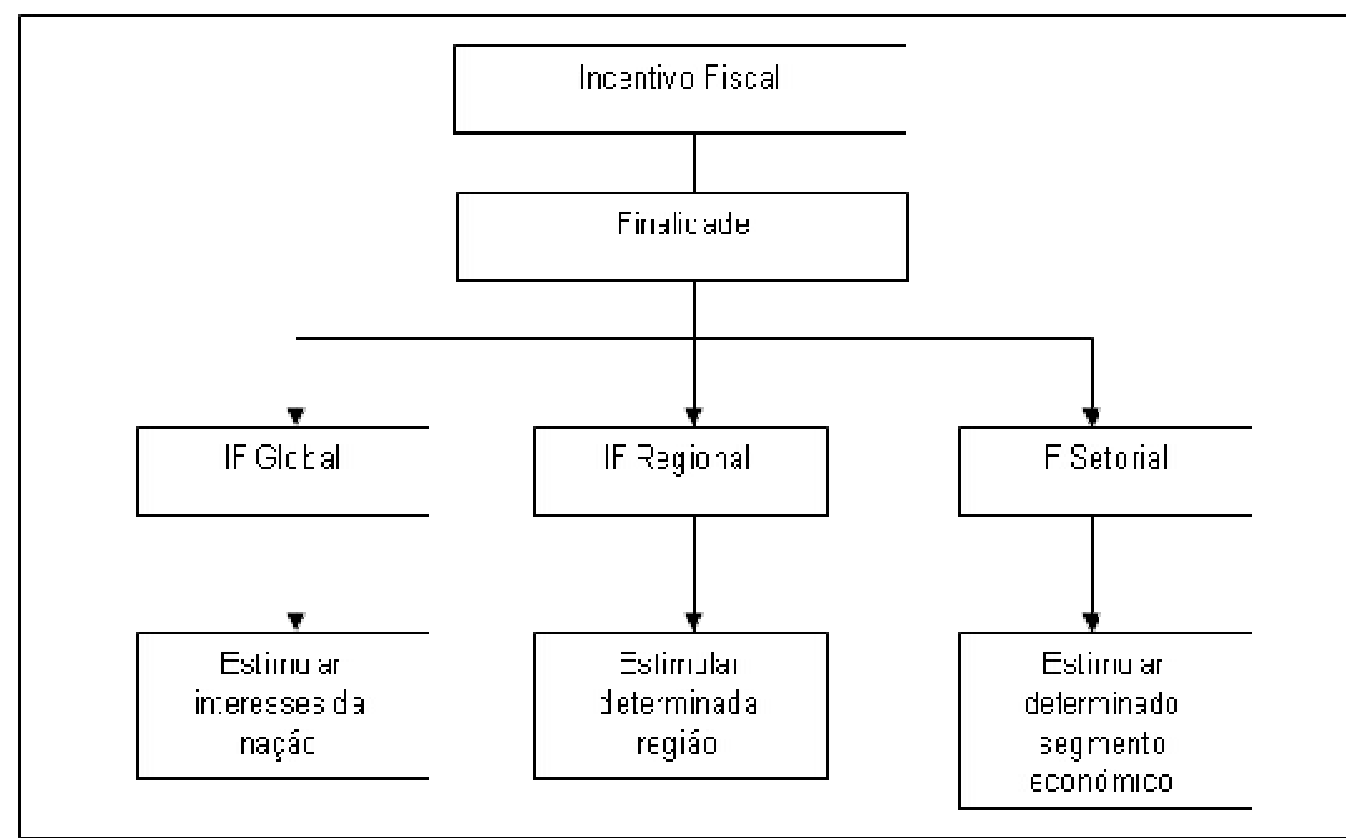

Figura 11 - Incentivos fiscais segundo a finalidade

Com base no exposto em relação à renúncia fiscal, benefícios fiscais e incentivos fiscais, temse, em resumo, que: 
- A renúncia fiscal é a forma pela qual o Estado utiliza os tributos para alcançar outros fins que não o de arrecadação, como, por exemplo, para incentivar certas atividades ou regiões. (FABRETTI, 2000, p. 301-302).

- Os benefícios fiscais, em geral, são voltados a determinados contribuintes, sem a imediata vinculação a qualquer contraprestação. São privilégios - sem objetivos outros que não o benefício dos próprios contribuintes -, concedidos pelo Estado, que abrangem fatos geradores e obrigações tributárias já ocorridas e consolidadas no tempo. Nesse gênero, incluem-se: a anistia - perdão total ou parcial da sanção tributária, isto é, da multa decorrente do ato ilícito tributário -; a remissão - perdão de ônus ou dívida, ou seja, é a liberalidade efetuada pelo credor, com o intuito de exonerar o devedor do cumprimento da obrigação, abrangendo tanto a obrigação que tenha por objeto o pagamento do tributo quanto a obrigação decorrente de penalidade - e o parcelamento. (DINIZ; RIBEIRO, 2004; DINIZ; FORTES, 2007, p. 274-291).

- Os incentivos fiscais são instrumentos baseados em desoneração tributária, mediante outorga, pelo Estado, de tratamento tributário diferenciado ao contribuinte, cujo objetivo é alcançar o desenvolvimento econômico e reduzir as desigualdades sociais nacionais e regionais, o incentivo à economia, o fomento a determinados setores produtivos ou regiões, o aumento do saldo da balança comercial, o desenvolvimento do parque industrial nacional, a geração de empregos, a colocação de produtos de fabricação nacional no mercado externo.

Em síntese, os incentivos fiscais não objetivam privilegiar o contribuinte, mas promover ações ou comportamentos em prol da sociedade. Fazem parte desse gênero: as isenções, as reduções de alíquota e de base de cálculo, a alíquota zero, as subvenções, os créditos presumidos, os subsídios e o diferimento. Assim, norma jurídica que não exija contrapartida diretamente vinculada à promoção do bem comum não institui incentivo fiscal, mas, sim, benefício fiscal, gerando privilégio diretamente dirigido ao contribuinte. (DINIZ; RIBEIRO, 2004; DINIZ; FORTES, 2007, p. 274-291; ELALI, 2007, p. 53; MELO, 2007, p. 140; RODRIGUES, 2007, p. 301).

\subsubsection{Imunidade, isenção e não-incidência}

Verifica-se, na literatura, a não existência de uniformidade na atribuição das denominações aos diferentes institutos jurídicos e aos diferentes estímulos tributários. Constata-se que 
imunidade, isenção e não-incidência, de forma geral, são identificadas sem uma clara e objetiva distinção de conceitos e, eventualmente, como se fossem o mesmo instituto ou instrumento jurídico.

Por exemplo, no que tange à imunidade e à isenção tributária, Aguiar (2002) afirma que: "Parte da doutrina tem tratado o instituto da isenção tributária como sendo uma forma de dispensa legal do tributo, assim como a imunidade tributária vem sendo tratada como forma de não incidência.” Relativamente à não-incidência e à isenção, Machado (2007, p. 251) ressalta que "o legislador, muitas vezes, trata como de não incidência casos de isenção, e isto tem efetivamente ensejado dúvidas intermináveis."

Dessa forma, entende-se importante destacarem-se os conceitos e o entendimento desses diferentes institutos e instrumentos jurídicos.

Entende-se imunidade como uma forma de exclusão de competência tributária, ou seja, uma limitação constitucional ao poder de tributar dos vários entes da Federação - União, Estados, Distrito Federal e Municípios - que não podem instituir tributos sobre os fatos ou pessoas imunizados pela Constituição Federal (CF).

A imunidade está sob tutela da Constituição Federal, não sendo matéria passível de ordenamento por lei ordinária. Entretanto, pode ocorrer de uma lei estadual, por exemplo, transcrever dispositivos constitucionais de imunidade, havendo, assim, mera repetição do texto constitucional por motivo de maior esclarecimento. Por outro lado, pode ocorrer, infelizmente, de a lei ordinária reproduzir o dispositivo constitucional denominando-o, indevidamente, de isenção, quando o correto é imunidade. Em virtude de que os entes federativos não possuem competência para instituir tributos sobre os fatos imunizados pela Constituição Federal, tais fatos configuram, então, hipótese de não-incidência constitucionalmente qualificada.

A imunidade é, assim, um princípio constitucional e não deve ser considerada como um benefício, um favor fiscal, uma renúncia à competência tributária ou um privilégio, pois seu objetivo é assegurar certos princípios fundamentais e resguardar os valores éticos e culturais, tais como: a liberdade de culto religioso, de associação política, sindical, de educação, de assistência social, de divulgação científica e cultural. (AGUIAR, 2002; BORGES, 2007, p. 
218; FABRETTI, 2000, p. 127; ICHIHARA, 2000, p. 120; MELO, 2007, p. 138; MORAES, 1998, p. 107; SEIXAS FILHO, 1989, p. 63; SILVA, 2001, p. 210).

A não incidência é a situação em que a regra jurídica de tributação não incide porque não se realiza a sua hipótese de incidência, ou, em outras palavras, são simples fatos econômicos nos quais não se configura o suporte fático.

A norma tributária é uma norma jurídica que se caracteriza por impor o pagamento do tributo a todo aquele que praticar fatos específicos devidamente previstos e definidos na própria norma tributária.

A não-incidência decorre da noção de hipótese de incidência - previsão legal de situações que, se concretizada no plano real, acarreta o fato gerador e, assim, o nascimento da obrigação tributária -, ou seja, enquanto a hipótese de incidência delineia o espectro de incidência da regra jurídica tributária, a não-incidência é representada por toda a área que transcende o campo da incidência do tributo. Assim, o conceito de não-incidência tributária pode ser correlacionado com o de incidência, ou seja, paralelamente ao fenômeno da incidência, encontra-se a figura da não-incidência.

Ocorre incidência da lei tributária quando determinada pessoa ou coisa se encontra dentro do espectro coberto pela tributação, enquanto não-incidência ocorre quando determinada pessoa ou coisa se encontra fora do campo de incidência da regra jurídica de tributação, ou seja, a não-incidência ocorre em relação a todos os outros fatos não abrangidos pela hipótese de incidência.

O fundamental para caracterizar uma situação de não-incidência é que o fato gerador da obrigação tributária deixa de ocorrer por falta de tipicidade legal, no sentido de que o ente tributante não consegue enquadrar o fato ocorrido dentro daqueles fatos que compõem a hipótese de incidência ou previsão legal tributária. (AGUIAR, 2002; BORGES, 2007, p. 184; SEIXAS FILHO, 1989, p.11; SILVA, 2001, p. 215). A Figura 12 exibe o esquema de hipótese de incidência e não incidência tributária, conforme anteriormente exposto. 


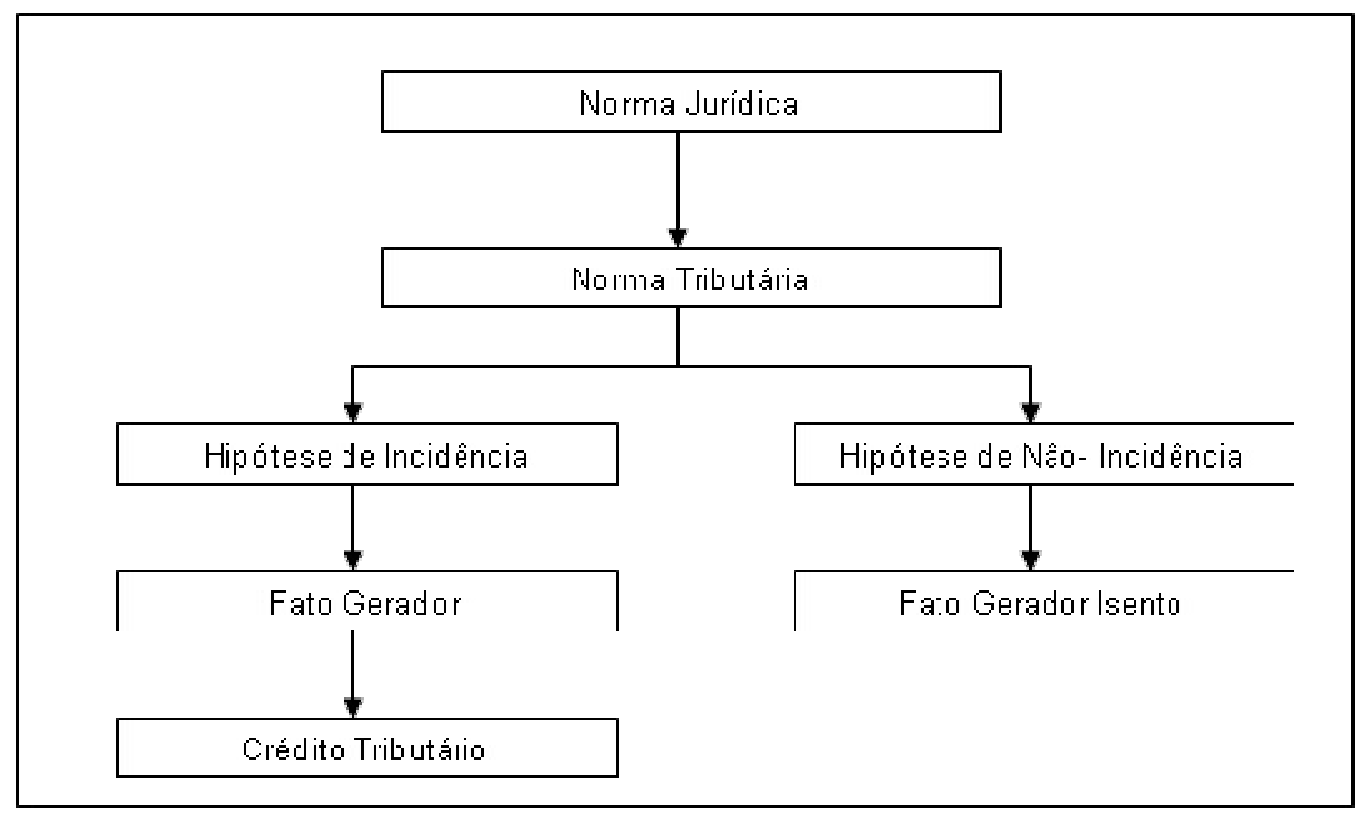

Figura 12 - Crédito tributário e fato gerador isento

Com relação à isenção, dentre as várias doutrinas que procuram explicá-la, pode-se apontar, pela sua relevância, duas que tratam da isenção como figura jurídico-tributária: a corrente tradicional e a corrente moderna.

Para a corrente tradicional, a isenção tem como natureza jurídica a dispensa legal do pagamento do tributo, considerada como exclusão do crédito tributário (Figura 9). Para os seguidores dessa teoria, necessariamente deve haver a incidência para, posteriormente, ocorrer a isenção, isto é, nasce a obrigação tributária, mas, por conseqüência da norma isencional, ela não se completa. Silva (2001, p. 216) esclarece que, entre outros juristas, seguem essa teoria Ruy Barbosa Nogueira, Rubens Gomes de Sousa, Bernardo Ribeiro de Moraes, Amilcar de Araújo Falcão, Gilberto de Ulhôa Canto.

A outra corrente, moderna, entende que a isenção é, juridicamente, uma não-incidência legalmente qualificada, incluindo-se, por efeito de lei, no campo da não-incidência. Dessa forma, devido à norma de incidência, o que seria tributado, em virtude da norma isencional, deixa de sê-lo, visto que essa norma, atingindo a hipótese de incidência, torna-a insuficiente para gerar os efeitos que lhe são próprios. Nesse caso, ao contrário da teoria tradicional, não haveria a possibilidade do nascimento da obrigação tributária, visto que o fato gerador abstrato não estaria completo. Silva (2001, p. 217) orienta que, entre outros, seguem essa teoria moderna José Souto Maior Borges, Geraldo Ataliba, Paulo de Barros Carvalho. 
Em princípio, o efeito fundamental da adoção da corrente tradicional ou moderna volta-se, primordialmente, para as conseqüências jurídicas da revogação da desoneração. Pela teoria legal - corrente tradicional -, revogada a isenção, a norma de incidência, imediatamente, passa a ser eficaz, novamente. Entretanto, adotada a teoria doutrinária - corrente moderna -, em ocorrendo a revogação, a tributação somente voltará a gerar o crédito conseqüente após o exercício, pelo princípio constitucional da anterioridade, entendendo-se que se teria uma nova incidência. (AVILA, 2005; BORGES, 2007, p. 160-197; HARADA, 2007, p. 250; PIRES, 2007, p. 22-23; SEIXAS FILHO, 1989, p. 9; SILVA, 2001, p. 216-218).

A Figura 13 apresenta uma síntese da isenção como exclusão do crédito tributário.

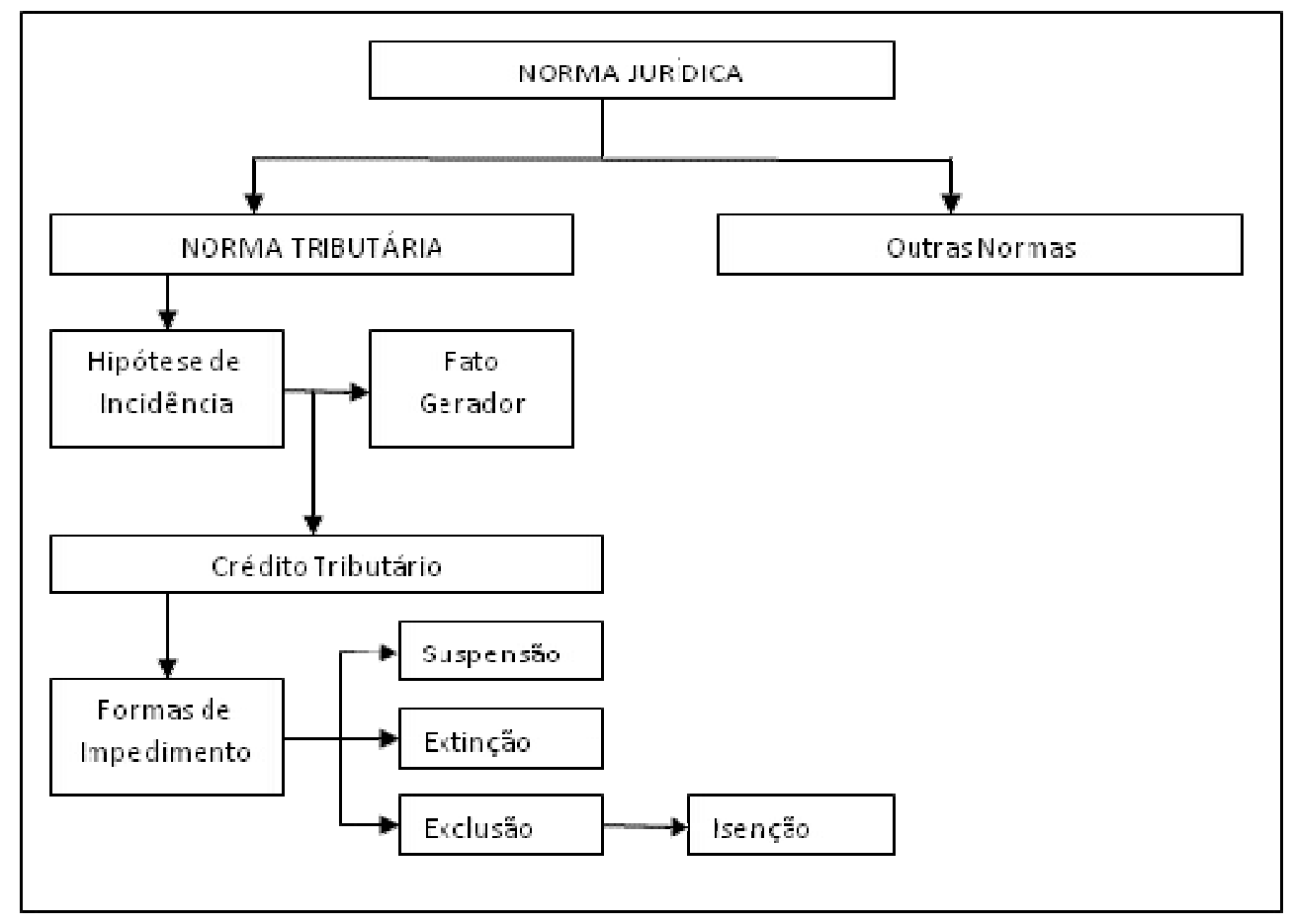

Figura 13 - A isenção como forma de impedimento tributário

Verifica-se que a distinção formal entre os conceitos de imunidade e isenção consiste em que, enquanto a imunidade está sempre instituída em texto constitucional, a isenção, mesmo tendo como ponto de partida preceito constitucional programático ou diretivo, é matéria afeta à lei ordinária ou complementar. Enquanto a imunidade pré-exclui a criação de regras jurídicas de tributação, a isenção subtrai, retira para fora, do campo de incidência da tributação, a pessoa ou o bem isento. (BORGES, 2007, p. 51-52-190; SEIXAS FILHO, 1989, p. 218). 
A Figura 14 apresenta uma síntese dos conceitos das figuras da imunidade, não-incidência e isenção.

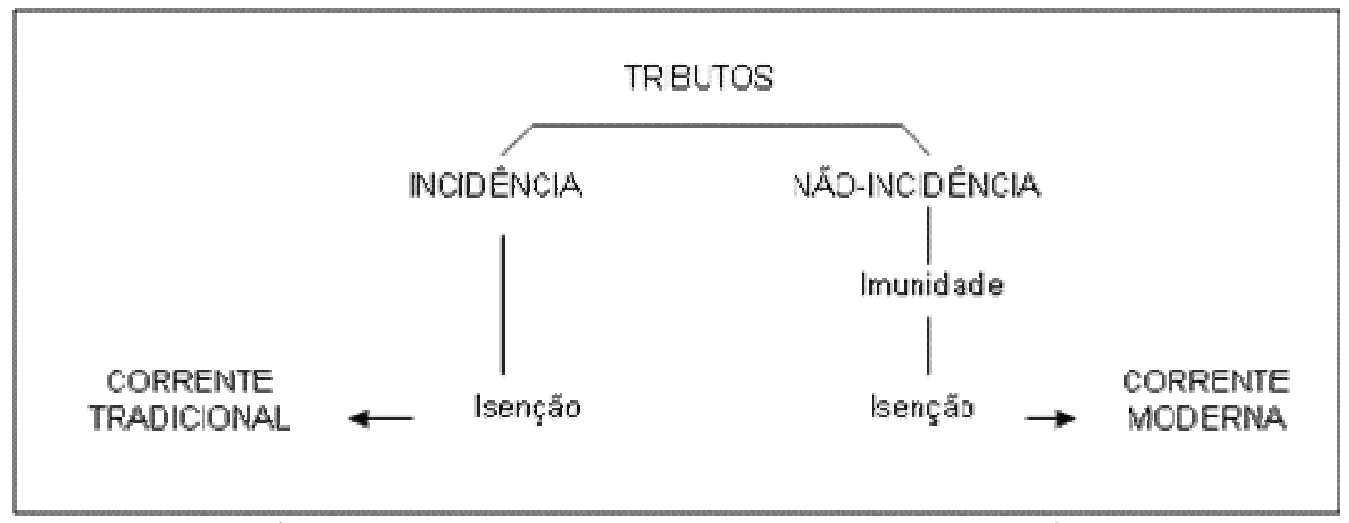

Figura 14 - Síntese dos conceitos das figuras da imunidade, não-incidência e isenção

Diante do exposto, considera-se que incentivos fiscais ou renúncias de receitas públicas referem-se à desoneração tributária com o objetivo de promover o desenvolvimento econômico regional e reduzir as desigualdades sociais. São instrumentos utilizados pelo Estado com o objetivo de melhorar a qualidade de vida da população.

São considerados incentivos fiscais: as isenções, as reduções de alíquotas e de base de cálculo, a alíquota zero, as subvenções, o crédito presumido, os subsídios e o diferimento.

Juridicamente existe uma diferenciação entre incentivos fiscais e benefícios fiscais. $\mathrm{O}$ primeiro exige uma contrapartida do contribuinte beneficiado, enquanto, no segundo, não existe tal obrigação. De outra forma, o incentivo fiscal gera resultados futuros enquanto o benefício fiscal objetiva resolver uma situação atual decorrente de fatos geradores ocorridos no passado.

Os incentivos fiscais podem decorrer da despesa pública ou da receita pública. Os vinculados à despesa pública são decorrentes de desembolsos feitos pelo Estado como, por exemplo, a subvenção, enquanto os vinculados à receita pública são decorrentes da renúncia físcal propriamente dita, situação na qual o valor do tributo não chega a ingressar nos cofres públicos como, por exemplo, a isenção. 
Outra classificação divide os incentivos em financeiros e tributários. Os primeiros atuam via despesa pública como, por exemplo, a subvenção. Os segundos atuam via receita pública como, por exemplo, a isenção.

Embora, economicamente, isenção e subvenção sejam categorias semelhantes, pois produzem os mesmos efeitos, juridicamente, são bastante distintas. Juridicamente, a subvenção pressupõe o recebimento do tributo e, posteriormente, a realização da despesa pública. Na isenção não se verifica essa circunstância, pois, segundo a corrente doutrinária moderna, a hipótese legal de isenção impede o próprio surgimento da obrigação tributária.

Nesse contexto, tanto a imunidade quanto a não-incidência não constituem benefício fiscal, incentivo fiscal ou renúncia fiscal. A imunidade decorre de princípio constitucional com objetivo de resguardar valores éticos e culturais, tais como: a liberdade de culto religioso, de associação política, sindical, de educação, de assistência social, de divulgação científica e cultural. A não-incidência decorre de ausência de previsão legal de tributação de fatos econômicos que são concretizados no plano real, ou seja, a não-incidência é representada por toda a área que transcende ao campo de incidência do tributo.

Para fins deste estudo, não se obedece ao rigor jurídico de distinção entre benefícios fiscais e incentivos fiscais, ou seja, uma vez que ambos têm o mesmo efeito no plano econômico consideram-se ambos os termos como sinônimos. Também não é relevante o fato de o incentivo ser decorrente da despesa ou da receita pública. Assim, consideram-se como incentivo fiscal os benefícios tributários que, de forma direta, reduzem a carga tributária da empresa, sejam passíveis de mensuração econômica objetiva e sejam registrados contabilmente. Dessa forma, este estudo inclui como incentivos fiscais: isenção, redução da base de cálculo ou da alíquota, subvenção, crédito presumido, subsídios.

Por outro lado, não estão incluídos os benefícios decorrentes de financiamentos subsidiados, obtidos do governo: a taxas, prazos ou condições mais favorecidas que o mercado os quais não são contabilizados pelas empresas e outros benefícios, tais como: o diferimento, a remissão e a anistia. 


\subsubsection{Reconhecimento, mensuração e evidenciação dos incentivos fiscais}

As fases de reconhecimento, mensuração e evidenciação dos fenômenos econômicos compõem o processo contábil. Na fase de reconhecimento, o fenômeno econômico é identificado e classificado, ou seja, é feita a sua identificação qualitativa como ativo, despesa, passivo ou receita. A seguir, deve-se definir a sua base de mensuração, ou seja, precisam-se atribuir valores monetários ao fenômeno econômico, como, por exemplo: atribuir uma base para o cálculo da depreciação, atribuir uma base para o reconhecimento da receita. Ressalte-se que, em diversas situações, o reconhecimento e a mensuração são feitos conjuntamente. A evidenciação envolve a ação de demonstrar para os usuários externos à organização o processo de reconhecimento e mensuração realizado. (HENDRIKSEN; VAN BREDA, 1992; LOPES; MARTINS, 2005).

Assim, pode-se estabelecer a visão do processo contábil:

\footnotetext{
O processo contábil é composto pelas etapas de reconhecimento, mensuração e evidenciação das atividades econômicas, sendo resultado de um amplo conjunto de forças econômicas, sociais, institucionais e políticas. Essas forças delineiam as principais características do processo contábil tendo em vista o grau de influência dos agentes interessados em sua evolução. (LOPES, MARTINS, 2005, p. 52).
}

O processo contábil, quando voltado à satisfação de informações internas à organização é caracterizado como contabilidade gerencial e uma das suas principais características é o fato de não estar sujeito a regras ou normas contábeis. Porém, quando o processo contábil está voltado a informar os usuários externos, ele é caracterizado como contabilidade societária ou financeira e a sua principal característica é estar sujeito a regras ou às normas e princípios contábeis.

\subsubsection{No contexto brasileiro}

Sob a ótica da contabilidade financeira, a estrutura conceitual básica da contabilidade, no Brasil, até 31.12 2007, estava alicerçada na Resolução CFC no 750 do Conselho Federal de Contabilidade, de 29 de dezembro de 1993 e na Deliberação CVM nㅡ 29 da Comissão de Valores Mobiliários, de 05 de fevereiro de 1986. A Resolução do CFC elencou, conceituou e dispôs sobre a amplitude de diversos princípios de contabilidade e tornou-os obrigatórios no exercício da profissão do contabilista, enquanto a Deliberação da CVM aprovou e referendou o pronunciamento do Instituto dos Auditores Independentes do Brasil - IBRACON sobre a 
Estrutura Conceitual Básica da Contabilidade divulgado em janeiro de 1986 que, originalmente, foi elaborado pelo Instituto Brasileiro de Pesquisas Contábeis, Atuariais e Financeiras - IPECAFI.

Além do problema da divisão da estrutura conceitual da contabilidade em duas partes, no Brasil existe um outro de hierarquia no que se refere à normatização de assuntos contábeis. (LOPES; MARTINS, 2005, p. 124). Diversos órgãos governamentais emitem normas de contabilidade societária, como, por exemplo, a Secretaria da Receita Federal do Brasil, o Banco Central do Brasil, a Superintendência de Seguros Privados. Nesse sentido, Carvalho et al. (2006, p. 14) afirmam que:

[...] normatização contábil é tarefa técnica que não compete ao governo fazer e sim a todos os reais interessados: auditores, companhias preparadoras de demonstrações contábeis, analistas de investimentos e de mercados de capitais, credores, acadêmicos que pesquisam nessa área e sindicatos de trabalhadores que negociam remuneração variável com base em lucros e resultados.

Embora a norma máxima existente para regulação contábil das sociedades anônimas de capital aberto no Brasil seja a Lei no 6404, de 15 de dezembro de 1976, essas sociedades devem atender às normas da CVM que "tem autoridade para normatizar assuntos ligados à evidenciação dessas empresas", e às normas do CFC que, embora não tenha autoridade legal para isso, exerce influência sobre o comportamento dos profissionais da área contábil em virtude do seu poder fiscalizador. (LOPES; MARTINS, 2005, p. 124).

A fim de amenizar esses problemas, pela Resolução CFC no 1.055 de 07 de outubro de 2005, foi criado no Brasil o Comitê de Pronunciamentos Contábeis - CPC, com o objetivo de estudar, preparar e emitir pronunciamentos sobre procedimentos técnicos de contabilidade e divulgar informações dessa natureza, para permitir a emissão de normas pelas entidades reguladoras brasileiras, visando à centralização e uniformização do seu processo de produção, levando sempre em conta a convergência da Contabilidade Brasileira aos padrões internacionais. A inovação do CPC com relação à produção e regulamentação de normas contábeis é percebida à medida que reúne representantes de entidades da área privada, do mundo acadêmico e do setor governamental em busca de soluções a problemas comuns (CPC, 2007). 
Seguindo o movimento global de convergência à padronização dos procedimentos contábeis, no Brasil foi sancionada a Lei 11.638 de 28 de dezembro de 2007, com vigência a partir de 1을 de janeiro de 2008, que implementou diversas medidas direcionadas ao alinhamento dos procedimentos contábeis nacionais àqueles utilizados internacionalmente.

Com relação aos incentivos fiscais, no Brasil, a Lei das Sociedades Anônimas - LSA, o Regulamento do Imposto de Renda - RIR, o IBRACON, a CVM e o CFC, por exemplo, dispõem sobre normas contábeis relativas à sua mensuração, registro e evidenciação.

\subsection{Lei das Sociedades Anônimas}

A Lei das Sociedades Anônimas, até 31 de dezembro de 2007, no artigo 182, parágrafo 1으, letra d, determinava que as doações e subvenções para investimento recebidas pelas companhias abertas fossem classificadas como reservas de capital.

Art. 182. A conta do capital social discriminará o montante subscrito e, por dedução, a parcela ainda não realizada.

$\S 1^{\underline{0}}$ Serão classificadas como reservas de capital as contas que registrarem:

[...]

d) as doações e as subvenções para investimento.

Porém, com a promulgação da Lei 11.638/2007, a letra d, do parágrafo $1^{\circ}$, do artigo 182 da Lei 6.404/1976 foi revogada e a nova disposição para registro dos incentivos fiscais está estabelecida no artigo 195, letra a, da Lei 6.404/76:

A assembléia geral poderá, por proposta dos órgãos da administração, destinar para a reserva de incentivos fiscais a parcela do lucro líquido decorrente de doações e subvenções governamentais para investimentos, que poderá ser excluída da base de cálculo do dividendo obrigatório.

Assim, segundo a disposição anterior, Art. 182, parágrafo 1ํㅡ, letra d, da Lei 6.404/1976, os incentivos fiscais eram contabilizados da seguinte forma:

- Pelo valor da doação ou subvenção recebida

\begin{tabular}{|l|l|}
\hline D & Ativo \\
\hline C & $\begin{array}{l}\text { Reservas de Capital } \\
\text { Reserva de Incentivos Fiscais }\end{array}$ \\
\hline
\end{tabular}

De acordo com a nova disposição, Art. 195, letra a, os incentivos fiscais devem ser contabilizados da seguinte forma: 
- $\quad$ Pelo valor da doação ou subvenção recebida:

\begin{tabular}{|l|l|}
\hline D & Ativo \\
\hline C & Receita de Doações (ou Subvenções) para Investimento \\
\hline
\end{tabular}

- $\quad$ Na formação da reserva de incentivos fiscais, pelo valor da doação ou subvenção recebida:

\begin{tabular}{|l|l|}
\hline D & Lucros Acumulados \\
\hline C & $\begin{array}{l}\text { Reservas de Lucros } \\
\text { Reserva de Incentivos Fiscais }\end{array}$ \\
\hline
\end{tabular}

Observe-se que a Lei 6.404/1976 trata, explicitamente, somente dos casos de recebimento de doação e subvenção governamentais para investimento. Os casos de obtenção de benefícios fiscais, tais como, isenção e redução de impostos, não são mencionados no texto legal.

O Regulamento do Imposto de Renda (RIR), Decreto no 3.000 de 1999 e alterações posteriores determinam, nos artigo 443, item I, e 545, que, na apuração do lucro real, não devem ser computadas as subvenções para investimentos, inclusive mediante isenção ou redução de impostos concedidos como estímulo à implantação ou expansão de empreendimentos econômicos, e as doações feitas pelo Poder Público, desde que sejam registradas como reserva de capital. O valor do imposto que deixar de ser pago em virtude das isenções e reduções não poderá ser distribuído aos sócios e, também, deve ser registrado como reserva de capital, que, a exemplo das subvenções, somente poderá ser utilizado para absorção de prejuízos ou aumento do capital social. O valor do imposto incentivado, lançado em contrapartida à conta de reserva de capital não será dedutível na determinação do lucro real, conforme o:

Art. 443. Não serão computadas na determinação do lucro real as subvenções para investimento, inclusive mediante isenção ou redução de impostos concedidos como estímulo à implantação ou expansão de empreendimentos econômicos, e as doações, feitas pelo Poder Público, desde que (Decreto-lei no 1.598, de 1977, Art. 38, § 2º, e Decreto-lei no 1.730, de 1979, Art. 1丷, inciso VIII):

I - registradas como reserva de capital que somente poderá ser utilizada para absorver prejuízos ou ser incorporada ao capital social, observado o disposto no art. 545 e seus parágrafos; ou

[...]

Art. 545. O valor do imposto que deixar de ser pago em virtude das isenções e reduções [...] não poderá ser distribuído aos sócios e constituirá reserva de capital da pessoa jurídica, que somente poderá ser utilizada para absorção de prejuízos ou aumento do capital social (Decreto-lei no 1.598 , de 1977, Art. 19, § 3o, e Decreto-lei no 1.730 , de 1979, Art. 1丷, inciso I).

$\S 1$ Consideram-se distribuição do valor do imposto (Decreto-lei no 1.598 , de 1977, Art. 19, § 4º, e Decreto-lei no 1.825 , de 22 de dezembro de 1980, Art. 2o, § 3o):

I - a restituição de capital aos sócios, em casos de redução do capital social, até o montante do aumento com incorporação da reserva;

II - a partilha do acervo líquido da sociedade dissolvida, até o valor do saldo da reserva de capital. 
§ $3 \mathrm{O}$ valor da isenção ou redução, lançado em contrapartida à conta de reserva de capital nos termos deste artigo, não será dedutível na determinação do lucro real.

Observe-se que a legislação do imposto de renda, diferentemente da legislação societária, dispõe, explicitamente, sobre as isenções ou reduções de impostos concedidos pelo poder público, ressaltando que, além das doações e subvenções para investimentos, as isenções ou reduções de impostos não devem ser computadas na apuração do lucro real. Porém, seguindo a mesma linha de interpretação da legislação societária, a legislação fiscal determina a contabilização dos incentivos fiscais em reserva de capital sem transitar pelo resultado do exercício.

Dessa forma, a contabilização da redução ou isenção do imposto de renda pessoa jurídica, segundo a legislação fiscal, é feita pelo valor bruto, sem considerar a isenção ou redução do imposto, conforme segue:

- Pelo valor bruto do imposto de renda apurado, sem considerar a redução ou isenção do imposto:

\begin{tabular}{|l|l|}
\hline D & Despesa de Imposto de Renda \\
\hline C & Imposto de Renda a Pagar \\
\hline
\end{tabular}

Em seguida é feita a contabilização do incentivo fiscal relativo à isenção ou redução do imposto de renda, conforme segue:

- Pelo valor da redução ou isenção do imposto

\begin{tabular}{|l|l|}
\hline D & Imposto de Renda a Pagar \\
\hline C & $\begin{array}{l}\text { Reservas de Capital } \\
\text { Reserva de Incentivos Fiscais }\end{array}$ \\
\hline
\end{tabular}

Ressalte-se que, até junho de 2008, não havia nenhuma alteração na legislação fiscal do imposto de renda alterando o procedimento preconizado pela Lei 11.638/2007 para registro dos incentivos fiscais, a fim de adequá-lo às normas dessa nova lei.

Pela nova sistemática da Lei 11.638/2007, o incentivo fiscal relativo à redução ou isenção do imposto de renda deve ser contabilizado no resultado do exercício afetando o lucro líquido do exercício. Assim, pelo valor líquido do imposto de renda, já deduzido o incentivo físcal de isenção ou redução, pode-se fazer o seguinte lançamento: 


\begin{tabular}{|l|l|}
\hline D & Despesa de Imposto de Renda \\
\hline C & Imposto de Renda a Pagar \\
\hline
\end{tabular}

Em seguida, pode ser transferido da conta Lucros Acumulados para a conta Reserva de Incentivos Fiscais, do grupo Reservas de Lucros, todas do patrimônio líquido. Dessa forma, considerando-se o valor do incentivo fiscal de isenção ou redução do imposto, pode-se fazer o seguinte lançamento:

\begin{tabular}{|l|l|}
\hline D & Lucros Acumulados \\
\hline C & $\begin{array}{l}\text { Reservas de Lucros } \\
\text { Reserva de Incentivos Fiscais }\end{array}$ \\
\hline
\end{tabular}

\subsection{Instituto dos Auditores Independentes do Brasil - IBRACON}

O IBRACON, dispondo sobre os incentivos fiscais, aprovou em, 1ำ de janeiro de 1984 a NPC XVIII - Normas e Procedimentos de Contabilidade - Contabilização do Valor Relativo às Isenções ou Reduções do Imposto sobre a Renda, orientando que:

[...] nos casos de isenção ou reduções de imposto sobre a renda, as demonstrações contábeis devem refletir o encargo do imposto contabilizado pelo seu valor líquido, sendo apropriado, no mesmo exercício, de lucros acumulados, a crédito da Reserva de capital, o montante do benefício fiscal.

Recomenda, ainda, o IBRACON que tal forma de registro contábil seja adotada mesmo que haja prejuízo contábil e lucro real (tributável), ou lucro contábil inferior ao valor do benefício fiscal. Esse procedimento assegura a não-tributação do montante equivalente a isenções ou reduções, comprometendo lucros passados ou futuros - conforme o caso -para constituição da reserva requerida.

Observe-se que a orientação do IBRACON é que se registre, contabilmente, o valor correspondente ao imposto de renda a pagar efetivo, ou seja, debitando-se em Despesa com Imposto de Renda e creditando-se Imposto de Renda a Pagar o valor do imposto de renda deduzido da isenção ou redução correspondente. A parcela relativa à redução ou isenção deve ser debitada em Lucros Acumulados e creditada em uma Reserva de Capital.

Note-se que esse procedimento preconizado pelo IBRACON difere da norma atual preconizada pela Lei 11.638/2007 apenas em relação ao grupo de reservas que abriga o valor do incentivo. Enquanto, na nova norma contábil, o grupo de reservas à qual pertence a conta que recebe o registro contábil é Reservas de Lucros, na norma editada pelo IBRACON o grupo de reservas é Reservas de Capital. Ressalte-se, todavia, que, tanto na norma do IBRACON quanto na Lei 11.638/2007, o resultado do exercício é afetado pelo valor do incentivo fiscal. 


\subsection{Comissão de Valores Mobiliários - CVM}

Porém, dispondo de forma diferente do IBRACON, a CVM determinou, por meio do OfícioCircular/CVM/PTE/no 309/86, de 17 de dezembro de 1986, item 7: Provisão para imposto de renda e incentivos fiscais, que as empresas de capital aberto contabilizassem o valor relativo às isenções ou reduções do imposto de renda como se devido fosse. Dessa forma, o valor bruto do imposto de renda, sem considerar-se o incentivo fiscal da isenção ou redução do imposto, deve ser contabilizado da seguinte forma:

\begin{tabular}{|l|l|}
\hline D & Despesa com Imposto de Renda \\
\hline C & Imposto de Renda a Pagar \\
\hline
\end{tabular}

Pela parcela da isenção ou redução do imposto, embutida no valor provisionado, deve-se contabilizar o seguinte:

\begin{tabular}{|l|l|}
\hline D & Imposto de Renda a Pagar \\
\hline C & $\begin{array}{l}\text { Reservas de Capital } \\
\text { Reserva de Incentivos Fiscais }\end{array}$ \\
\hline
\end{tabular}

Observe-se que essa forma de registro dos incentivos fiscais está em consonância com as disposições da legislação fiscal. Em ambos os casos, os incentivos fiscais não afetam o resultado líquido do exercício.

Objetivando eliminar dualidade de princípios contábeis, o IBRACON, por meio do Comunicado Técnico no 1/89 de 20/1/89, suspendeu a vigência da NPC XVIII até que a matéria seja objeto de reestudo.

A CVM vem, ao longo dos anos da sua atuação, buscando aperfeiçoar e manter atualizado o seu arcabouço normativo contábil. Para tanto, divulga, anualmente, um Ofício-Circular emitido pela sua área técnica que tem como objetivo principal esclarecer dúvidas sobre a aplicação das Normas de Contabilidade pelas Companhias Abertas. Nesse sentido, a CVM, por meio do Ofício-Circular/CVM/SNC/SEP no 01/2007, de 14 de fevereiro de 2007, atualizou a consolidação das suas normas contábeis em que, dentre outras orientações, tratou da questão dos incentivos fiscais nos itens 8.1; 8.2; 16.1; e 30.15. 
O procedimento de contabilização dos incentivos fiscais preconizado pela CVM, segundo o item 8.1, estabelece que:

\begin{abstract}
$\mathrm{Na}$ demonstração do resultado do exercício, o imposto de renda devido deverá ser provisionado pelo valor bruto a recolher. Em nota explicativa às demonstrações contábeis deverá ser evidenciada a parcela relativa a incentivos fiscais embutida no valor bruto provisionado e feita referência à disposição legal permissionária da utilização dos incentivos. Nos casos de isenção temporária, o imposto que seria devido será computado para determinação do resultado líquido do exercício e, posteriormente, transferido para a respectiva reserva de capital, indicando, em nota explicativa, as datas de início e término do benefício.
\end{abstract}

A determinação, portanto, é que os incentivos fiscais sejam contabilizados da seguinte forma:

a) Pelo valor bruto, sem considerar o incentivo fiscal da isenção ou redução do imposto

\begin{tabular}{|l|l|}
\hline D & Despesa com Imposto de Renda \\
\hline C & Imposto de Renda a Pagar \\
\hline
\end{tabular}

b) Pela parcela da isenção ou redução do imposto, embutida no valor provisionado

\begin{tabular}{|l|l|}
\hline D & Imposto de Renda a Pagar \\
\hline C & $\begin{array}{l}\text { Reservas de Capital } \\
\text { Reserva de Incentivos Fiscais }\end{array}$ \\
\hline
\end{tabular}

Verifica-se que, no Ofício-Circular/CVM/SNC/SEP no 01/2007, de 14 de fevereiro de 2007, a CVM manteve a mesma interpretação do Ofício-Circular/CVM/PTE/nº 309/86, de 17 de dezembro de 1986.

Ressaltando a importância dos incentivos fiscais, o item 8.2 do Ofício-Circular no 01/2007 alerta que:

Tendo em vista que, para muitas empresas, especialmente aquelas beneficiárias de incentivos fiscais, uma das informações mais relevantes diz respeito a essa condição, estamos requerendo que, além das informações previstas na referida Deliberação, sejam também divulgadas, relativamente às companhias abertas e companhias beneficiárias de incentivos fiscais, suas controladas, controladoras e coligadas, informações sobre a existência de benefícios fiscais, de qualquer natureza, contemplando, no mínimo, o tipo do benefício, o prazo ou vencimento e o montante da economia tributária realizada no exercício.

Para o completo entendimento dos aspectos relacionados ao presente tópico devem ser divulgados, também, os montantes pagos/recolhidos de cada imposto e/ou contribuição no exercício social.

Tratando da divulgação em nota explicativa das subvenções governamentais, os itens 16.1 e 30.15 do Ofício-Circular nº 01/2007 dispõem que:

A companhia deve divulgar as seguintes informações:

a. A existência, a natureza e os montantes mensuráveis das subvenções governamentais ou das assistências governamentais de que a entidade se beneficia, bem como as práticas contábeis. 
b. Descumprimento de condições contratadas relativas às subvenções ou a existência de outras contingências.

c. Principais compromissos assumidos pela entidade por conta das subvenções.

d. Eventuais subvenções a reconhecer, após cumpridas as condições contratuais.

Complementarmente, a CVM por meio da Nota Explicativa da Instrução CVM no 59 de 22 de dezembro de 1986, no item 2 - Reservas de Capital, fez os seguintes comentários adicionais a respeito das subvenções:

\begin{abstract}
Em relação às subvenções recebidas pela companhia, elas podem ser classificadas em dois tipos diferentes: subvenções para investimento e subvenções para custeio.

As subvenções para investimento são registradas contabilmente como reserva de capital. Normalmente, referem-se a valores de que a companhia se beneficia a título de devolução, isenção ou redução de impostos devidos, ou de valores recebidos destinados à expansão de suas atividades, sob a forma de investimentos para capital fixo ou capital de giro. É o caso, por exemplo, de devolução de IPI ou ICM e de isenção temporária de imposto de renda como incentivo regional ou setorial.

As subvenções para custeio são constituídas por auxílio financeiro comumente recebido de forma periódica pela companhia para fazer face às suas despesas, insuficientemente cobertas pelas receitas de suas operações (tarifas). São, contabilmente, classificadas como receita extraordinária. É exemplo típico o caso das ferrovias brasileiras.
\end{abstract}

Ademais, sobre as subvenções, por meio da Deliberação 488/2005, a CVM esclareceu, no item 89, que:

Ao decidir se uma prática contábil deve ser divulgada, a administração deve considerar se a divulgação ajudaria os usuários a entender a maneira pela qual as transações e os eventos são demonstrados nos relatórios contábeis apresentados. As práticas contábeis de uma entidade incluem, porém não estão restritas, ao seguinte:

[...]

t. subvenções do governo.

Com relação às reservas de capital, a Nota Explicativa da Instrução CVM no 59/86, que dispõe sobre a obrigatoriedade de elaboração e publicação da Demonstração das Mutações do Patrimônio Líquido pelas companhias abertas, esclarece que:

\begin{abstract}
As reservas de capital representam acréscimos efetivos aos ativos da companhia que não foram originados dos lucros auferidos em suas operações, por não representarem efeitos de seus próprios esforços, mas assim de contribuições de acionistas ou de terceiros para o patrimônio líquido da companhia com o fim de propiciar recursos para o capital (em sentido amplo), inclusive contribuições governamentais sob a forma de subvenções por incentivos fiscais.
\end{abstract}

Note-se que as orientações da CVM, de forma geral, são direcionadas para os incentivos fiscais do tipo subvenções, porém em sua Nota Explicativa da Instrução CVM 59/86 ressalta que as subvenções se referem a valores relativos à devolução, isenção ou redução de impostos. 
Com a edição da Lei 11.638/2007, a CVM tratou da questão das doações e subvenções governamentais na Instrução CVM 469 de 02/05/2008 e sua respectiva Nota Explicativa, cuja aplicação deve ser feita a partir do encerramento do exercício social iniciado a partir de $1 \stackrel{0}{\circ}$ de janeiro de 2008. A Instrução determina no artigo 3ำ que:

Art. 3- (...) as doações e subvenções, decorrentes de operações e eventos ocorridos a partir da vigência da Lei no 11.638, de 2007, serão transitoriamente registrados em contas específicas de resultado de exercícios futuros, com divulgação do fato e dos valores envolvidos, em nota explicativa, até que a CVM edite norma específica sobre a matéria.

Parágrafo único. Os saldos das reservas de capital referentes [...] a doações e subvenções para investimento, existentes no início do exercício social de 2008, poderão ser mantidos nessas respectivas contas até a sua total utilização, na forma prevista em lei.

Na Nota Explicativa à Instrução CVM 469, o item 2 ressalta que a Lei 11.638/2007 extinguiu as reservas de capital relativas às doações e subvenções para investimentos. A Nota esclarece, quanto à contabilização, que:

As doações e subvenções para investimento devem ser consideradas redução do custo do ativo a que elas se referem, no caso de ativos não monetários, ou, nos demais casos, como receita a ser apropriada ao resultado do exercício em que ocorrer a sua realização. Assim, as doações e as subvenções para investimento passam a ser registradas, de imediato ou na medida de sua realização, no resultado do exercício, afetando, portanto, o lucro líquido do exercício, que é a base para cômputo tanto dos dividendos, quanto do imposto de renda e contribuição social.

Para não haver perda do direito de dedução do imposto de renda e da contribuição social, a Nota Explicativa possibilita a destinação do valor do incentivo para conta de reserva de lucros, em conta específica de reserva de incentivos fiscais, permitindo a sua exclusão da base de cálculo do dividendo obrigatório.

Com relação à mensuração das subvenções, a Nota Explicativa dispõe que:

\begin{abstract}
As subvenções devem ser reconhecidas como receita em uma base racional e sistemática ao longo do tempo, a fim de confrontá-las com os respectivos custos. Enquanto não reconhecidos como receitas, os ganhos por doação ou subvenção para investimento serão registrados como resultados não realizados. A CVM emitirá norma específica aprovando pronunciamento que se encontra em elaboração no CPC que trata dessa matéria.
\end{abstract}

Sobre os saldos das contas de reservas de incentivos fiscais existentes até 31 de dezembro de 2007, a Nota Explicativa estabelece que "os saldos existentes no início do exercício de 2008 poderão ser mantidos por prazo indeterminado nas respectivas contas de reserva, para sua utilização na forma do Art. 200 da Lei no 6.404, de 1976." 
Além disso, a Instrução CVM 469 estabeleceu uma regra transitória, até que norma específica seja emitida, permitindo que as doações e subvenções para investimento que ocorrerem no exercício de 2008 sejam registradas como resultado de exercícios futuros, devendo o fato e os valores envolvidos serem divulgados em nota explicativa.

Depreende-se, assim, que, pelas normas da Instrução CVM 469, as doações e subvenções devem ser contabilizadas da seguinte forma:

a) Pelo valor bruto da doação ou subvenção recebida registra-se o ativo tendo-se como contrapartida a conta transitória de receita diferida:

\begin{tabular}{|l|l|}
\hline D & Ativo \\
\hline C & $\begin{array}{l}\text { Resultado de Exercícios Futuros } \\
\text { Receita de Doações e Subvenções para Investimento }\end{array}$ \\
\hline
\end{tabular}

b) No exercício em que ocorrer a sua realização, pelo valor da doação ou subvenção realizada, faz-se o registro da realização da receita diferida:

\begin{tabular}{|l|l|}
\hline D & $\begin{array}{l}\text { Resultado de Exercícios Futuros } \\
\text { Receita de Doações e Subvenções para Investimento }\end{array}$ \\
\hline C & Receita de Doações e Subvenções para Investimento \\
\hline
\end{tabular}

c) Para possibilitar a dedução do incentivo da base de cálculo do imposto de renda e da contribuição social, pelo valor da doação ou subvenção realizada:

\begin{tabular}{|l|l|}
\hline D & Lucros Acumulados \\
\hline C & $\begin{array}{l}\text { Reservas de Lucros } \\
\text { Reserva de Incentivo Fiscal }\end{array}$ \\
\hline
\end{tabular}

\subsection{Conselho Federal de Contabilidade - CFC}

$\mathrm{O}$ CFC, de sua parte, relativamente às entidades privadas que recebem incentivos fiscais, subvenções, contribuições, auxílios e doações governamentais, estabeleceu procedimentos contábeis e informações mínimas a serem divulgadas em notas explicativas, inicialmente, na NBC T 10.16 - Entidades que recebem subvenções, contribuições, auxílios e doações, de 13 de dezembro de 2001, aprovada por meio da Resolução CFC 922, de 13 de dezembro de 2001 e, posteriormente, na NBC T 19 - Aspectos contábeis específicos, item 19.4 - Incentivos Fiscais, Subvenções, Contribuições, Auxílios e Doações Governamentais, aprovada por meio da Resolução CFC 1.026, de 15 de abril de 2005, com vigor a partir de 01 de janeiro de 2006, a qual revogou a NBC T 10.16. 
O artigo terceiro da referida Resolução CFC 1.026/2005 orienta que:

Art. 30 Enquanto a Lei dispuser de forma diferente da NBC T 19.4, os incentivos fiscais e subvenções para investimento podem ser registrados no patrimônio líquido como reserva de capital e devem ser divulgados em notas explicativas os efeitos no Resultado, desde que:

a) o subvencionador tenha a intenção em destinar os incentivos fiscais e subvenções para investimentos; e

b) o subvencionado tenha a obrigação de aplicar tais recursos em investimentos relacionados à implantação, modernização ou expansão de empreendimentos econômicos específicos.

Pelo exposto na Resolução CFC 1.026/2005 entende-se que a contabilização dos incentivos fiscais seja feita da seguinte forma:

a) Pelo valor bruto, sem considerar o incentivo fiscal da isenção ou redução do imposto

\begin{tabular}{|l|l|}
\hline D & Despesa com Imposto de Renda \\
\hline C & Imposto de Renda a Pagar \\
\hline
\end{tabular}

b) Pela parcela da isenção ou redução do imposto, embutida no valor provisionado

\begin{tabular}{|l|l|}
\hline D & Imposto de Renda a Pagar \\
\hline C & Reservas de Capital \\
\hline
\end{tabular}

Com relação aos termos nela empregados, a NBC T 19.4 esclarece que se entende por:

Incentivo fiscal - renúncia total ou parcial de receita fiscal do governo em favor de entidades públicas ou privadas com objetivo de geração de benefícios sociais e econômicos, sendo:

I - Isenção tributária - desobrigação legal de pagamento de tributo;

II - Redução tributária - desobrigação legal de pagamento parcial de tributo.

Empréstimo Subsidiado - é o empréstimo normalmente obtido do governo a taxas, prazos ou condições mais favorecidas que o mercado;

Perdão de Empréstimo Subsidiado - valor total ou parcial do empréstimo que o governo renuncia mediante o cumprimento de determinado compromisso vinculado ao contrato.

Subvenção - contribuição pecuniária, prevista em lei orçamentária, concedida por órgãos do setor público a entidades públicas ou privadas, com o objetivo de cobrir despesas com a manutenção e o custeio destas, com ou sem contraprestação de bens ou serviços da beneficiária dos recursos.

Contribuições - transferências correntes ou de capital, previstas na lei orçamentária ou especial, concedidas por entes governamentais a autarquias e fundações e a entidades sem fins lucrativos, sendo:

I - Transferências Correntes: destinadas à aplicação em custeio e manutenção destas, sem contrapartida de bens ou serviços da beneficiária dos recursos; e

II - Transferências de Capital: destinadas aos investimentos ou inversões financeiras.

Auxílios - previstos em lei orçamentária, destinados a despesas de capital de entes públicos ou de entidades privadas sem fins lucrativos.

Doações - transferências gratuitas, em caráter definitivo, de recursos financeiros ou do direito de propriedade de bens, com finalidade de custeio, investimento e imobilizações, sem contrapartida do beneficiário.

Com relação ao reconhecimento, a NBC T 19.4 estabelece o seguinte:

1) Os incentivos fiscais, as contribuições e os auxílios devem ser reconhecidos quando existir razoável certeza de que: 
a. a entidade cumprirá com todas as condições estabelecidas entre as partes;

b. o benefício será recebido.

2) As subvenções e as doações devem ser reconhecidas no recebimento efetivo.

3) O perdão do empréstimo subsidiado deve ser reconhecido como receita quando existir certeza razoável de que a entidade cumprirá os compromissos assumidos.

4) O reconhecimento da receita deve ser o mesmo, independente da forma com que o benefício foi concedido, em dinheiro ou como isenção e redução de passivo.

5) O reconhecimento das receitas de incentivos fiscais, subvenções, contribuições, auxílios e doações devem ser confrontados com os custos e as despesas correspondentes.

6) Admite-se o reconhecimento da receita, no momento de seu recebimento, nos casos em que não haja bases de confrontação com custos ou despesas, ao longo dos períodos beneficiados.

7) No caso de recebimento de ativos, o reconhecimento da receita deve ser proporcional ao cumprimento do compromisso assumido pelo seu recebimento.

8) Recebimento de subvenções, contribuições, doações ou outros instrumentos assemelhados que se destinem a cobrir custos ou perdas já incorridas, ou com o propósito de dar imediato suporte financeiro, sem custos futuros relacionados, deve ser reconhecido em conta de receita.

Com relação ao registro contábil, a NBC T 19.4 estabelece que:

a) Os incentivos fiscais, subvenções, contribuições, auxílios, perdão de empréstimo subsidiado e doações devem ser registrados em contas específicas de receita e constar das demonstrações do resultado das entidades beneficiadas;

b) Os valores recebidos a título de incentivos fiscais, subvenções, contribuições, auxílios e doações, devem ser registrados em conta específica de receita, segregados por tipo de benefício;

c) Nos casos em que a entidade perde o direito a um benefício, já registrado como receita, e tiver que ser devolvido, a entidade deve, primeiramente, compensar esse valor com receitas diferidas relacionadas com o mesmo benefício. Nos casos em que essa compensação não for suficiente ou não houver receita diferida, a perda não-compensada deve ser reconhecida imediatamente como despesa.

Pelo disposto nos itens "a" e "b" acima, entende-se que a contabilização dos incentivos fiscais deve ser feita da seguinte forma: 
a) Pelo valor líquido, já deduzido o incentivo fiscal de isenção ou redução do imposto

\begin{tabular}{|l|l|}
\hline D & Despesa de Imposto de Renda \\
\hline C & Imposto de Renda a Pagar \\
\hline
\end{tabular}

b) Pelo valor do incentivo fiscal de isenção ou redução do imposto

\begin{tabular}{|l|l|}
\hline D & Lucros Acumulados \\
\hline C & Reservas de Lucros \\
\hline
\end{tabular}

Como se pode observar, segundo as orientações do CFC, existem duas possibilidades de registro contábil dos incentivos fiscais: a primeira delas determina a contabilização dos incentivos fiscais como receita (e, conseqüentemente, tendo, como contrapartida, reservas de lucros) e a segunda permite a contabilização como reserva de capital (tendo, conseqüientemente, como contrapartida, imposto de renda a pagar).

Com relação às notas explicativas, a NBC T 19.4 estabelece que devem conter, no mínimo, as seguintes informações:

a) os valores recebidos por tipo de benefício: incentivos fiscais, subvenções, contribuições, auxílios, perdão de empréstimos subsidiados e doações;

b) critérios contábeis adotados, quando do registro dos benefícios recebidos;

c) principais compromissos assumidos pela entidade por conta dos benefícios recebidos;

d) potenciais ganhos ou perdas em decorrência do cumprimento ou descumprimento de compromissos assumidos em decorrência dos benefícios fiscais;

e) contingências relativas aos benefícios fiscais.

Ressalte-se que, embora houvesse determinações do CFC, CVM e da legislação do imposto de renda para registro dos incentivos fiscais, as companhias abertas brasileiras utilizavam as mais variadas formas para contabilização dos citados incentivos até 31 de dezembro de 2007, conforme se pode observar pelo Quadro 1. 
Quadro 1 - Exemplos de registro dos incentivos fiscais por algumas companhias abertas brasileiras

\begin{tabular}{|c|c|c|}
\hline Empresa & Tipo Inc Fiscal & Contabilização \\
\hline 1 & Inc Fiscais do Nordeste - FINOR & Não informado \\
\hline 2 & Redução no pagto do ICMS & D - ICMS a Pagar / C - Res. Subv p/Inv. \\
\hline 3 & $\begin{array}{l}\text { Crédito presumido ICMS nas compras } \\
\text { interestaduais. }\end{array}$ & D - ICMS a Recuperar / C - Res Subv p/Inv \\
\hline 3 & $\begin{array}{l}\text { Red IPI combinado com a manutenção do crédito } \\
\text { do IPI. }\end{array}$ & Não informado \\
\hline 3 & Dedução gastos c/ pesq e desenv p/ fins de IR e CS. & Não informado \\
\hline 4 & $\begin{array}{l}\text { Isenção IR concedida p/ extinta SUDAM e redução } \\
75 \% \text { IR concedida p/ ADA. }\end{array}$ & D - IR a Pagar / C - Res Cap \\
\hline 4 & $\begin{array}{l}\text { Crédito estímulo com redução do saldo devedor do } \\
\text { ICMS em } 85 \%\end{array}$ & $\begin{array}{l}\text { Apropriados ao resultado como redução dos } \\
\text { impostos s/vendas }\end{array}$ \\
\hline 5 & Redução e isenção IR & $\begin{array}{l}\text { A Desp. IR é regist como se devida fosse. A } \\
\text { redução/isenção é revertida a crédito do PL. }\end{array}$ \\
\hline 6 & Redução a zero alíq PIS e COFINS s/ venda livros. & Não é contabilizado \\
\hline 7 & Red IRPJ & D - Desp IRPJ / C - Res Inc Fisc IR \\
\hline 8 & $\begin{array}{l}\text { Financiamentos ICMS. Os valores devidos têm } \\
\text { redução de } 75 \% \text { a } 99 \% \text { em relação ao total } \\
\text { financiado. }\end{array}$ & Res Inc Fiscais \\
\hline 8 & Isenção/Red IR região Nordeste & $\begin{array}{l}\text { D - Desp IR / C - IR a Pagar } \\
\text { D - IR Pagar / C - Res Inc Fisc }\end{array}$ \\
\hline 9 & Redução 90\% ICMS devido & $\begin{array}{l}\text { D - ICMS a Recolher } \\
\text { C - Res Subv p/Inv }\end{array}$ \\
\hline 10 & $\begin{array}{l}\text { Créd Presum ICMS resultando em carga tributária } \\
\text { de } 3 \% \text { e Red Base Cálc ICMS. }\end{array}$ & $\begin{array}{l}\text { D - ICMS a Pagar } \\
\text { C - Res Subv p/Inv }\end{array}$ \\
\hline 10 & $\begin{array}{l}\text { Red IPI combinado com a manutenção do crédito } \\
\text { do IPI. }\end{array}$ & Não informado \\
\hline 10 & Dedução gastos c/ pesq e desenv p/ fins de IR e CS. & Não informado \\
\hline 10 & Isenção PIS e COFINS & Não informado \\
\hline 11 & $\begin{array}{l}\text { Subvenções não atreladas a projeto de } \\
\text { investimento }\end{array}$ & Outras Rec Operac \\
\hline 11 & Subvenção atrelada a projeto de investimento. & Reserva Capital \\
\hline 11 & Subvenção federal região Nordeste e ZFM & Reserva Capital \\
\hline 12 & Redução de $25 \%$ do incremento de ICMS devido. & Não informado \\
\hline
\end{tabular}

Observe-se, assim, que não existia um critério uniforme para registro e evidenciação dos incentivos fiscais até 31/12/2007, sendo contabilizados ora no patrimônio líquido, ora em contas de resultado e, outras vezes, não contabilizados. Dessa forma, fica evidenciada a importância da regulação do registro contábil e da evidenciação dos incentivos fiscais nas demonstrações contábeis para que se possa, ao menos, avaliar quanto do lucro ou prejuízo apresentado pela empresa é incentivo fiscal e quanto é resultado da sua eficiência operacional.

Os Quadros 2 e 3 abaixo, apresentam uma comparação das formas de contabilização dos incentivos fiscais segundo os diversos órgãos, antes e depois da Lei 11.638/2007. 
Quadro 2 - Formas de contabilização dos incentivos fiscais segundo a LSA, RIR, IBRACON, CVM e CFC antes da Lei 11.638/2007

\begin{tabular}{|l|l|l|l|}
\hline \multicolumn{1}{|c|}{ Fonte } & \multicolumn{1}{c|}{ D } & \multicolumn{1}{c|}{ C } & \multicolumn{1}{c|}{ Observação } \\
\hline LSA & Ativo & $\begin{array}{l}\text { Reserva de Capital } \\
\text { Reserva de Incentivos Fiscais }\end{array}$ & Pelo valor do incentivo \\
\hline RIR & Imposto de Renda a Pagar & $\begin{array}{l}\text { Reserva de Capital } \\
\text { Reserva de Incentivos Fiscais }\end{array}$ & Pelo valor do incentivo \\
\hline IBRACON & Lucros Acumulados & Reserva de Capital & Pelo valor do incentivo \\
\hline CVM & Imposto de Renda a Pagar & $\begin{array}{l}\text { Reserva de Capital } \\
\text { Reserva de Incentivos Fiscais }\end{array}$ & Pelo valor do incentivo \\
\hline CFC & Imposto de Renda a Pagar & Reserva de Capital & Pelo valor do incentivo \\
\cline { 2 - 5 } & Lucros Acumulados & Reservas de Lucros & Pelo valor do incentivo \\
\hline
\end{tabular}

Quadro 3 - Formas de contabilização dos incentivos fiscais segundo a LSA, RIR, IBRACON, CVM e CFC, após a Lei 11.638/2007

\begin{tabular}{|c|c|c|c|}
\hline Fonte & D & $\mathbf{C}$ & Observação \\
\hline LSA & Ativo & Receita & Pelo valor do incentivo \\
\hline RIR & Imposto de Renda a Pagar & $\begin{array}{l}\text { Reserva de Capital } \\
\text { Reserva de Incentivos Fiscais }\end{array}$ & $\begin{array}{l}\text { Não há manifestação da } \\
\text { SRFB para } \\
\text { contabilização de forma } \\
\text { diferenciada. }\end{array}$ \\
\hline \multirow[t]{2}{*}{ IBRACON } & Imposto de Renda a Pagar & Reserva de Capital & \multirow{2}{*}{$\begin{array}{l}\text { Segundo informação no } \\
\text { site do IBRACON, a } \\
\text { contabilização deve ser } \\
\text { feita segundo a NBC T } \\
19.4 \text { do CFC. }\end{array}$} \\
\hline & Lucros Acumulados & Reservas de Lucros & \\
\hline \multirow[t]{3}{*}{ CVM } & Ativo & $\begin{array}{l}\text { Resultado de Exercícios Futuros } \\
\text { Receita de Doações e } \\
\text { Subvenções para Investimento }\end{array}$ & $\begin{array}{l}\text { Pelo valor bruto da } \\
\text { doação ou subvenção } \\
\text { recebida }\end{array}$ \\
\hline & $\begin{array}{l}\text { Resultado de Exercícios } \\
\text { Futuros } \\
\quad \text { Receita de Doações e } \\
\text { Subvenções para } \\
\text { Investimento }\end{array}$ & $\begin{array}{l}\text { Receita de Doações e } \\
\text { Subvenções para Investimento }\end{array}$ & $\begin{array}{l}\text { Pelo valor bruto da } \\
\text { doação ou subvenção } \\
\text { realizada }\end{array}$ \\
\hline & Lucros Acumulados & $\begin{array}{l}\text { Lucros Acumulados } \\
\text { Reserva de Incentivos Fiscais }\end{array}$ & $\begin{array}{l}\text { Pelo valor bruto da } \\
\text { doação ou subvenção } \\
\text { realizada. }\end{array}$ \\
\hline \multirow[t]{2}{*}{$\mathrm{CFC}$} & Imposto de Renda a Pagar & Reserva de Capital & \multirow{2}{*}{$\begin{array}{l}\text { Não há manifestação do } \\
\text { CFC para contabilização } \\
\text { de forma diferenciada. }\end{array}$} \\
\hline & Lucros Acumulados & Reservas de Lucros & \\
\hline
\end{tabular}

\subsubsection{Normas Contábeis sobre incentivos fiscais no âmbito internacional}

No âmbito internacional, o órgão responsável pela emissão de normas contábeis é o International Accounting Standards Board - IASB. Destaque-se a importância do maior organismo doméstico internacional, o Financial Accounting Standards Board-FASB.

Os Estados Unidos da América criaram, em 1930, a Junta de Normas de Contabilidade (Accounting Principles Board - APB) uma entidade que reunia vários profissionais de mercado, para produzirem as normas contábeis até então incipientes ou inexistentes. As 
normas expedidas pela APB tinham o caráter de "Princípios Contábeis Norte-Americanos Geralmente Aceitos" (Generally Accepted Accounting Principles - USGAAP). Posteriormente, esse modelo de produção de normas foi substituído e, em 1973, nos EUA foi criada uma instituição privada, sem fins lucrativos, exclusivamente voltada à elaboração de normas contábeis, denominada Junta de Normas de Contabilidade Financeira (Financial Accounting Standard Board - FASB). As normas expedidas pela FASB são conhecidas como Normas de Contabilidade Financeira (Financial Accounting Standards - FAS). (CARVALHO et al., 2006, p. 13-15).

Com a criação da FASB nos EUA em 1973, as demais economias desenvolvidas reagiram e criaram, no mesmo ano, um organismo igualmente privado e sem fins lucrativos denominado, inicialmente, de International Accounting Standard Committee - IASC (Comitê de Normas Internacionais de Contabilidade). As normas emitidas pelo IASC eram denominadas de International Accounting Standards - IAS (Normas Internacionais de Contabilidade) e aplicadas, particularmente, no âmbito da Comunidade Européia - CE. Posteriormente, em 2000, o IASC foi reformado em sua constituição e passou a denominar-se International Accounting Standards Board - IASB (Junta de Normas Internacionais de Contabilidade). As normas emitidas pelo IASB são denominadas de International Financial Reporting Standards - IFRS (Normas Internacionais de Relatórios Financeiros) (CARVALHO et al., 2006, p. 01 $16)$.

Em março de 2001, foi formada a Fundação IASC como uma entidade sem finalidade lucrativa localizada no Estado de Delaware, US. A Fundação IASC é a principal entidade da IASB, uma elaboradora independente de normas contábeis sediada em Londres, Reino Unido. Em 1ำ de abril de 2001, a IASB assumiu a responsabilidade de elaboração das normas contábeis do seu predecessor, o IASC. Isso foi resultado de uma reestruturação baseada nas recomendações do relatório Recommendations on Shaping IASC for the Future. A estrutura da IASB segue as seguintes principais características: a Fundação IASC é uma organização independente que tem dois corpos principais: os Trustees e o IASB, assim como um Standards Advisory Council and the International Financial Reporting Interpretations Committee. Os Trustees da Fundação IASC apontam os membros do IASB, exercem a supervisão e o levantamento de fundos necessários, mas a única responsabilidade do IASB é a adequação das normas contábeis (IASB, 2007). 
A Figura 15 abaixo apresenta uma síntese da evolução dos órgãos normatizadores e das normas de contabilidade nos Estados Unidos da América (EUA) e na Comunidade Européia (CE).

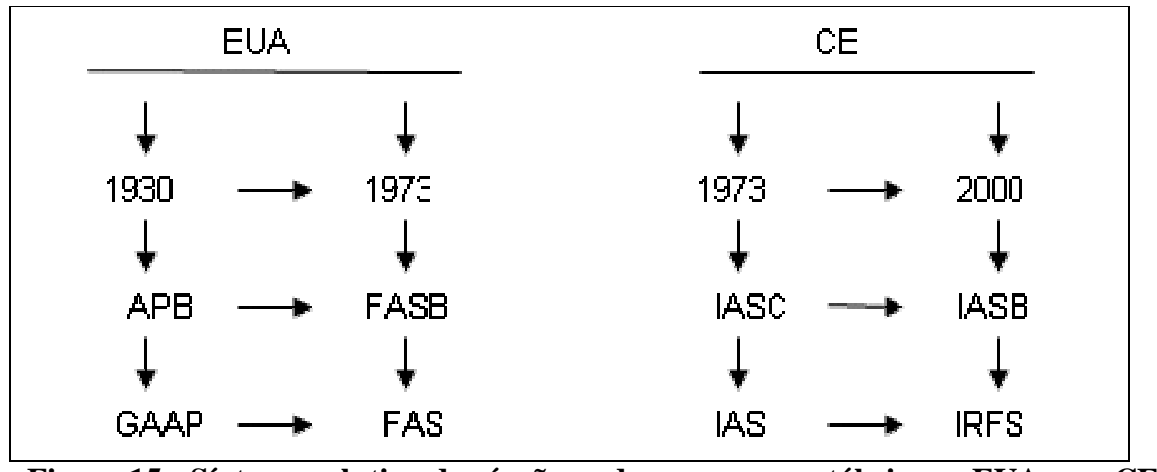

Figura 15 - Síntese evolutiva dos órgãos e das normas contábeis nos EUA e na CE

Com relação aos incentivos tributários, a FASB emitiu o Statement no 116 e a IASB o pronunciamento IAS 20 dispondo, entre outros, sobre os pontos abrangidos pelos documentos e o seu tratamento contábil.

No contexto dos EUA, o Statement n- 116 - Accounting for Contributions Received and Contributions Made foi emitido em junho de 1993 e estabelece normas contábeis para contribuições e aplicações para todas as entidades que recebem ou fazem contribuições. Em geral, contribuições recebidas são reconhecidas como receitas ao seu valor justo no período em que são recebidas. Contribuições feitas são reconhecidas como despesas ao seu valor justo no período em que são pagas. Assim, entende-se que o seguinte lançamento deve ser feito no período correspondente ao recebimento da contribuição, pelo valor justo:

\begin{tabular}{|l|l|}
\hline D & Ativo \\
\hline C & Receitas \\
\hline
\end{tabular}

O Statement 116 é eficaz para as demonstrações financeiras emitidas para os anos fiscais que começaram após 15 de dezembro de 1994, exceto para as organizações sem fins lucrativos com menos do que US\$ 5 milhões de ativos totais e menos do que US\$ 1 milhão de despesas anuais. Para essas organizações, o relatório é eficaz para os anos fiscais que começaram após 15 de dezembro de 1995, sendo encorajada a aplicação antecipada.

A FASB e a IASB efetivaram um memorando de compreensão (Memorandum of Understanding between the FASB and the IASB), em 27 de fevereiro de 2006, no qual ambos 
os órgãos registraram a promessa feita em setembro de 2002 e reafirmada nas suas reuniões de abril e outubro de 2005 para a convergência dos USGAAP e das IFRS, de envidar os seus melhores esforços: a) para tornar, o quanto antes, as suas normas de relatórios financeiros existentes totalmente compatíveis, assim como praticáveis; e b) coordenar seus programas de trabalho futuro para assegurar que, uma vez isso seja conseguido, a compatibilidade seja mantida.

Os tópicos para análise da convergência a curto prazo foram divididos entre a FASB e a IASB. O tópico relativo às Government grants ficou sob a responsabilidade da IASB, porém não está incluído na agenda de curto prazo.

A limitação do número de projetos de convergência a curto prazo direciona as Juntas da FASB e IASB a focarem as áreas principais, nas quais as práticas atuais de contabilidade USGAAP e IFRS sejam consideradas como candidatas para melhoria. O objetivo para 2008 é fazer progresso significativo, nos projetos conjuntos em áreas identificadas por ambas as Juntas, nas quais as práticas contábeis atuais de USGAAP e IFRS estejam necessitando de melhoria.

No âmbito da comunidade européia, a norma internacional de contabilidade IAS 20 Accounting for government grants and disclosure of government assistance, deve ser aplicada para o registro contábil e evidenciação das subvenções e outras formas de auxílio governamental, para os exercícios que começaram a partir de 01 de janeiro de 1984, a qual esclarece o seguinte:

- Subvenções governamentais são auxílios feitos pelo governo na forma de transferência de recursos para uma entidade, em virtude de compromissos passados ou futuros relacionados às atividades operacionais da entidade. Não estão incluídas as formas de auxílio governamental que não possam ser, razoavelmente, mensuradas e as transações com o governo que não possam ser diferenciadas das transações comerciais normais da entidade.

- Auxílio governamental é uma ação do governo com o objetivo de fornecer um benefício econômico específico para uma entidade ou grupo de entidades selecionadas sob determinados critérios. A norma não inclui os benefícios concedidos indiretamente somente por meio da ação que afeta as condições gerais de comércio, tais como: o fornecimento de infra-estrutura para desenvolvimento de determinadas áreas ou a 
imposição de restrições comerciais para os concorrentes. O auxílio governamental não inclui o fornecimento de infra-estrutura para melhoria da rede geral de transporte e comunicação e o fornecimento de facilidades, como irrigação ou reticulação de água, que estão disponíveis sobre uma base indeterminada para o benefício de uma comunidade local inteira.

Segundo o IAS 20, a subvenção governamental feita na forma de transferência de um ativo não monetário, tal como terra ou outros recursos, para o uso da entidade, deverá ser mensurada e contabilizada, assim como o ativo respectivo, pelo valor justo.

As subvenções governamentais, incluindo as subvenções não monetárias pelo valor justo, não poderão ser reconhecidas até que haja uma razoável certeza de que:

a) a entidade irá cumprir com as condições a ela impostas;

b) as subvenções serão recebidas.

As subvenções governamentais devem ser reconhecidas como receita durante os períodos necessários para confrontá-las com os custos respectivos, os quais a entidade tem intenção de compensar, numa base sistemática.

As subvenções governamentais podem ser relacionadas aos ativos ou às receitas:

Subvenções relacionadas aos ativos são aquelas cuja condição preliminar é que a entidade qualificada para recebê-las deverá comprar, construir ou de outra forma adquirir ativos de longo prazo. São apresentadas no balanço patrimonial, considerando o valor que exceder ao da subvenção como receita diferida ou deduzindo a subvenção até chegar ao montante do ativo. Os lançamentos a serem feitos, em cada caso, podem ser exemplificados como segue:

a) Pelo valor da subvenção recebida, considerando o valor que exceder ao da subvenção como receita diferida:

\begin{tabular}{|l|l|}
\hline D & Disponível \\
\hline C & $\begin{array}{l}\text { Resultado de Exercícios Futuros } \\
\text { Receita Diferida }\end{array}$ \\
\hline
\end{tabular}

b) Pelo valor da subvenção aplicado na aquisição do ativo de longo prazo, deduzindo a subvenção até chegar ao montante do ativo: 


\begin{tabular}{|l|l|}
\hline D & Ativo \\
\hline C & Disponível \\
\hline
\end{tabular}

c) Pelo mesmo valor da depreciação do ativo subvencionado:

\begin{tabular}{|l|l|}
\hline D & $\begin{array}{l}\text { Resultado de Exercícios Futuros } \\
\text { Receita Diferida }\end{array}$ \\
\hline C & Receita Subvenções Governamentais \\
\hline
\end{tabular}

Subvenções relacionadas à receita são outras subvenções governamentais àquelas relacionadas aos ativos. São apresentadas como um crédito na Demonstração do Resultado do Exercício (DRE), de uma das seguintes formas:

a) separadamente ou sob um cabeçalho geral tal como "Outras receitas" ou,

b) alternativamente, são deduzidas das despesas relacionadas à subvenção na DRE.

O lançamento do valor recebido no período é o seguinte:

\begin{tabular}{|l|l|}
\hline D & Ativo \\
\hline C & Receita de recebimento de subvenção \\
\hline
\end{tabular}

Existe um projeto de emenda ao IAS 20, de fevereiro de 2004, cujo objetivo é empreender uma melhoria no seu conteúdo informacional. A razão principal para o projeto de emenda é que o Comitê tem algumas reservas sobre as exigências do IAS 20, em particular, o fato de que as exigências de reconhecimento do IAS 20, muitas vezes, resultam numa contabilidade que é inconsistente com a estrutura conceitual da contabilidade da IASB. Por exemplo, a exigência do parágrafo 12 de reconhecer as subvenções 'como receita durante o período necessário para confrontá-las com os custos relacionados os quais tem intenções de compensar' pode resultar em uma entidade reconhecendo um montante no balanço patrimonial como um crédito diferido quando a entidade não tem nenhuma responsabilidade ou compromisso.

Além de ser inconsistente com a estrutura conceitual contábil da IASB, as exigências de reconhecimento do IAS 20 são, também, inconsistentes com os mais recentes pronunciamentos do corpo de normas padrões que se relacionam às transferências nãorecíprocas em geral ou, mais especificamente, às concessões governamentais. Por exemplo, o FASB Statement no 116 - Accounting for Contributions Received and Contributions Made (SFAS 116) enquanto isenta as subvenções governamentais para as entidades comerciais do seu alcance, fornece um modelo de contabilidade que pode ser aplicado às subvenções 
governamentais e que é consistente com a estrutura conceitual contábil da IASB. Na Austrália, o UIG Abstract 11 Accounting for contributions of, or contributions for the acquisition of, non-current assets, enquanto especifica um tratamento diferente para as contribuições sujeitas às condições do SFAS 116 é, também, consistente com aquele Framework (estrutura conceitual contábil da IASB).

O IAS 20 contem inúmeras opções. Por exemplo, uma entidade que recebe subvenções para financiar a aquisição de um item de propriedade, planta ou equipamento está autorizada a deduzir a subvenção do montante carregado naquele item, e uma entidade que recebe uma subvenção não-monetária está autorizada a mensurar o ativo e a subvenção pelo montante nominal em vez de ao valor justo. Adicionalmente ao fato da existência de opções, a norma reduz a comparabilidade das demonstrações financeiras, particularmente, as opções do IAS 20 resultam num relatório incompleto de ativos controlados pela entidade e não fornecem informação relevante aos usuários das demonstrações financeiras.

O Comitê apontou que teria melhor ocasião para empreender uma reconsideração fundamental da contabilidade para subvenções governamentais (e outras transferência nãorecíprocas) uma vez que tem sido feito progresso com o projeto de reconhecimento de receitas. Entretanto, o Comitê ficou preocupado em deixar o IAS 20 na forma atual porque no curto prazo poderá ter efeitos negativos nos países que estão adotando o IFRS que, de alguma forma:

a) já tenha emitido norma para subvenções governamentais que estão consistentes com a estrutura do IASB ou

b) não tenha nenhuma exigência específica e exija que as entidades sigam estruturas conceituais similares à do IASB.

Isso poderia acarretar que as entidades nesses países, após a primeira adoção dos IFRS, aplicassem uma contabilidade que seria menos consistente com a estrutura conceitual do que a contabilidade que usavam anteriormente.

O Comitê compreendeu, também, que alguns de seus parceiros que estabelecem normas nos países que estão adotando IRFS estavam particularmente preocupados com os efeitos da aplicação das exigências do IAS 20 para as demonstrações financeiras das entidades sem finalidade lucrativa. O Comitê entendeu que se os seus parceiros deixassem a IAS 20 na sua forma atual, seria provável que eles especificassem exigências contábeis diferentes daquelas 
do IAS 20 (que seriam mais consistentes com a estrutura conceitual) para entidades beneficiadas pelo setor público. O Comitê ressaltou que isso poderia resultar em uma infeliz e evitável diferença entre as exigências de relatório para entidades beneficiadas pelo setor público e as entidades orientadas para o lucro e, assim, concluiu que isso poderia empreender uma limitação no alcance do projeto para atualizar a IAS 20.

\subsubsection{Estudos sobre incentivos fiscais}

\subsubsection{Estudos sobre incentivos fiscais realizados no Brasil}

A fim de identificarem-se estudos anteriores sobre incentivos fiscais no Brasil, procedeu-se a uma busca nos periódicos nacionais utilizando diversas palavras-chave, tais como: incentivos fiscais, renúncia fiscal, isenção fiscal, isenção tributária, imunidade, subvenção, nãoincidência, tributo, tributação, imposto, desigualdade social e distribuição de renda.

$\mathrm{Na}$ seqüência, apresentam-se as pesquisas sobre incentivos fiscais realizadas no Brasil, encontradas na pesquisa realizada nos periódicos nacionais com o objetivo de apresentar um panorama do estado da arte.

A preocupação com os tributos no Brasil já estava retratada na Constituição Federal - CF de 1946 que estabelecia no seu artigo 31, inciso V, letra a, o princípio da imunidade tributária recíproca, que vedava à União, aos Estados e aos Municípios lançarem impostos sobre bens, rendas e serviços uns dos outros.

A Súmula 76 do Supremo Tribunal Federal, de 1964, (apud LACOMBE, 1966, p. 129-130), já apresentava a preocupação das empresas em obter o abrigo da lei para evitar o pagamento de impostos, expressando que "As sociedades de economia mista não estão protegidas pela imunidade fiscal do artigo 31, V, a, da Constituição Federal.”

Em virtude de que as ações do Estado eram consideradas intervencionistas ou dirigistas, Lacombe (1969) analisou os estímulos fiscais para identificação das duas espécies. Ele considera que todo imposto é uma forma de intervencionismo, pois o sistema tributário opera de forma global na economia do país, mas, dentro dessa medida intervencionista, qual seja a tributação, existem medidas dirigistas, de natureza fragmentária, como, por exemplo, os 
incentivos fiscais. A sua conclusão é de que os estímulos fiscais nada mais são do que uma manifestação do dirigismo econômico, não se tratando de intervencionismo.

Ele afirma que a intervenção do Estado em matéria econômica e social, mediante medidas fiscais, teve origem no mercantilismo, levando, de imediato, ao problema da extrafiscalidade e aos problemas da política fiscal intervencionista e dirigista.

A política fiscal dirigista é relativa às medidas de política tributária que pretende, exclusiva ou preferencialmente, por motivos específicos: políticos, sociais, militares, favorecer determinadas regiões e determinados setores.

O propósito de desenvolvimento de determinadas regiões gerou inúmeros programas de incentivos fiscais como, por exemplo, os da Superintendência do Desenvolvimento do Nordeste - SUDENE que concedeu incentivos fiscais para o desenvolvimento do Nordeste, os da Superintendência do Desenvolvimento da Amazônia - SUDAM que estendeu os incentivos concedidos aos investimentos no Nordeste aos investimentos na Região Amazônica, os incentivos às atividades agropecuárias e agroindustriais, incentivos na área do meio ambiente e outros.

Os incentivos fiscais criados para o desenvolvimento de determinados setores podem ser exemplificados pelos incentivos ao florestamento ou reflorestamento, os da Empresa Brasileira de Turismo - EMBRATUR que criou incentivo ao turismo, os incentivos aos projetos culturais sob a forma de doação ou patrocínio, os incentivos concedidos às sociedades de crédito imobiliário que isentam os seus lucros de tributação do imposto de renda, os incentivos à formação profissional pelas empresas, os incentivos ao programa de alimentação do trabalhador, os incentivos na área da saúde, os incentivos na área da educação (Fundo de Manutenção e Desenvolvimento do Ensino Fundamental e de Valorização do Magistério - FUNDEF e Fundo de Manutenção e Desenvolvimento da Educação Básica e de Valorização dos Profissionais da Educação - FUNDEB), os incentivos destinados ao desenvolvimento tecnológico industrial, os incentivos às exportações (Regime Aduaneiro Especial de Entreposto Industrial sob Controle Informatizado - RECOF), dentre outros.

Lacombe (1969) explica que, a partir de 1930, ocorreram modificações substanciais na política e na teoria fiscal acentuando as desigualdades naturais entre as diversas regiões do 
Brasil. O aumento da carga tributária, ocorrido principalmente com a Segunda Guerra Mundial, foi, ao mesmo tempo, causa e efeito do aspecto extrafiscal assumido, então, pela política fiscal. Assim, foi criada a Superintendência do Desenvolvimento do Nordeste SUDENE, pela Lei 3.692 de 15/12/1958, e a previsão de dois tipos de incentivos fiscais: os concedidos aos empreendimentos localizados na Região Nordestina e os concedidos às empresas sediadas em outras regiões, que aplicassem capitais no Nordeste. As primeiras, empresas localizadas no Nordeste, tinham isenção de tributos para a importação de equipamentos e redução de $50 \%$ do imposto de renda, inclusive para as novas indústrias que utilizassem matéria-prima da região ou a produzissem em volume inferior a $30 \%$ do consumo aparente da região. As segundas, empresas localizadas fora da região e de capital cem por cento nacional, poderiam efetuar a dedução de até 50\% do imposto de renda, em importâncias destinadas ao reinvestimento ou aplicação na indústria considerada pela SUDENE de interesse para o desenvolvimento nordestino.

Posteriormente, foram promulgadas outras leis com incentivos fiscais de dedução do imposto de renda, tais como:

- Lei 4.216 de 06/03/1963: estendeu à Região Amazônica os incentivos físcais já concedidos àqueles que aplicassem capitais no Nordeste;

- Lei 5.106 de 02/09/1966: permitiu abater do imposto de renda as importâncias aplicadas em florestamento ou reflorestamento;

- Decreto-lei 55 de 18/11/1966 e alterações posteriores: criou o Conselho Nacional de Turismo e a Empresa Brasileira de Turismo - EMBRATUR e concedeu incentivos fiscais e creditícios ao turismo.

Em virtude dos incentivos fiscais, o volume de investimentos na Amazônia cresceu consideravelmente e Cardoso (1971) preocupou-se em analisar se o valor proveniente da reavaliação do ativo imobilizado dos projetos em implantação na Amazônia podia ser considerado, também, para efeito de incentivos fiscais. Os incentivos fiscais em referência foram concedidos pela Lei 5174 de 27/10/1966 em favor da Região Amazônica, possibilitando a todas as pessoas jurídicas deduzir do imposto de renda:

- até $75 \%$ do valor das obrigações emitidas pelo Banco da Amazônia S.A., que as empresas adquirissem; 
- até $50 \%$ do valor do imposto devido para inversão em projetos agrícolas, pecuários, industriais, de agricultura e de serviços básicos declarados pela SUDAM como de interesse para o desenvolvimento da Amazônia. Nesse caso, o benefício somente seria concedido se a empresa beneficiária da aplicação financiasse, no mínimo, 1/3 (um terço) do montante dos investimentos totais do projeto com recursos próprios.

Cardoso (1971) concluiu que a reavaliação do ativo imobilizado, estabelecida pela Lei 3470 de 28/11/1958, teria que ser considerada e distribuída proporcionalmente entre o capital proveniente de recursos próprios e o de incentivos fiscais. Assim, a parcela de reavaliação que coubesse ao capital de recursos próprios geraria incentivos fiscais do imposto de renda.

$\mathrm{Na}$ ótica setorial, o incentivo de isenção do imposto de renda sobre os juros e comissões relativos a financiamentos imobiliários, assim como a isenção da parte da receita de correção monetária que se mantinha em reserva para aumento de capital, tornava as sociedades de crédito imobiliário livres de tributação sobre seu lucro e motivou o estudo realizado por Santos e Candiota (1974) com o objetivo de verificar como era composto o lucro e como ele era influenciado pela variação de alguns fatores componentes do total de recursos existentes nas sociedades de crédito imobiliário.

Uma sociedade de crédito imobiliário integra o Sistema Financeiro da Habitação, que é controlado pelo Banco Nacional da Habitação - BNH e, basicamente, capta recursos por meio da colocação de letras imobiliárias e cadernetas de poupança, e aplica-os em financiamentos para construção, aquisição e melhoramentos de imóveis.

O estudo foi motivado em decorrência do crescimento dessas sociedades que, no espaço de sete anos, passaram, de um percentual inexpressivo, a representar 1/8 do total de empréstimos para investimentos existentes no país em meados de 1973. Os autores apontam como causas do expressivo crescimento a renda real dos investimentos em poupança e os incentivos fiscais concedidos aos aplicadores em letras imobiliárias e depósitos de poupança, principais fontes de recursos das sociedades de crédito imobiliário. A isenção do imposto de renda sobre os juros e comissões relativos a financiamentos imobiliários, assim como a isenção da parte de receita de correção monetária que se mantinha em reserva para aumento de capital, tornava as sociedades de crédito imobiliário livres de tributação sobre seu lucro. 
As sociedades de crédito imobiliário conseguiam obter rendimentos reais de 10 a $12 \%$ ao ano, podendo, assim, pagar aos seus depositantes de $6 \%$ a $7 \%$ ao ano em juros reais, enquanto suas concorrentes, as caixas econômicas e as associações de poupança e empréstimo, continuavam operando com condições e prazos extremamente sensíveis à flutuação da conjuntura financeira de momento.

No desenvolvimento do estudo, para cada tipo de recurso aplicado ou captado foi calculado um índice de resultado (renda ou custo) que, ponderado pela sua participação no total da empresa, mostra o efeito específico desse recurso no seu lucro. Da soma desses efeitos individuais resultou o quadro de lucratividade potencial de cada empresa. Uma vez estabelecidos os índices de resultado, que devem ser os mesmos para todas as sociedades de crédito imobiliário, pode-se aplicar o sistema a qualquer uma delas, independente do volume e composição de recursos que ela apresente.

Após a análise dos resultados, Santos e Candiota (1974) concluíram que uma sociedade de crédito imobiliário, operando dentro dos limites estabelecidos pelo $\mathrm{BNH}$, em conformidade com as condições hipotéticas de mercado, apresentou um índice de rentabilidade de 3,9\% ao ano sobre o total de recursos operados, representando um retorno sobre os recursos próprios investidos da ordem de $89 \%$ ao ano.

Os resultados demonstram que os incentivos fiscais concedidos às sociedades de crédito imobiliário, além de outros fatores, naturalmente, tiveram um efeito relevante na rentabilidade do ativo dessas empresas.

Outro incentivo, destinado à formação profissional nas empresas, motivou o estudo realizado por Roesch (1984), que avaliou o impacto da implementação da Lei 6.297/75, de incentivos fiscais à formação profissional nas empresas, com a finalidade de avaliar a eficiência econômica da política governamental e contribuir para esclarecer até que ponto os empresários estavam aproveitando os incentivos fiscais oferecidos pelo governo.

A Lei 6.297/75 foi regulamentada pelo Decreto 77.463/76 que estabeleceu os incentivos como dedução, feita diretamente do imposto de renda devido pela empresa, em valor equivalente à aplicação da alíquota efetiva sobre a soma dos investimentos, mais despesas de custeio efetuadas pelas empresas em programas de formação profissional. O programa financia até 
um limite de $35 \%$ das despesas de treinamento realizadas pelas empresas, mas limita a dedução a $10 \%$ do imposto de renda devido, podendo, o eventual excesso, ser aproveitado nos três exercícios seguintes. De forma geral, as despesas com formação são deduzidas em dobro pela empresa: primeiramente a dedução contábil como despesa operacional e, a seguir, a dedução extracontábil no imposto devido da empresa. Assim, no caso em que a empresa esteja sujeita a uma alíquota de, por exemplo, $30 \%$, o governo estaria contribuindo com $60 \%$ do custo do treinamento (porque a dedução é em dobro), enquanto a empresa estaria contribuindo com os restantes $40 \%$. Os recursos podem ser utilizados não só para os cursos de treinamento - desenvolvidos pela empresa ou por entidades externas - como também para as despesas de administração das atividades de treinamento, para as despesas de investimento que cobrem máquinas e equipamentos a serem utilizados nessas atividades e, ainda, para a construção de centros de treinamento nas empresas.

O propósito da lei foi um aumento nas oportunidades de formação profissional na empresa, derivado do estímulo monetário concedido ao empresário. A conseqüência seria o benefício trazido ao trabalhador pela melhoria de sua qualificação, como resultado do treinamento, podendo levar a maiores oportunidades de promoção na empresa ou ao aumento de suas perspectivas de emprego no mercado de trabalho. Por outro lado, deve ser enfatizado o benefício que seria trazido à empresa, em termos de um aumento na sua produtividade geral, como decorrência da maior qualificação da sua mão-de-obra, o que geralmente se traduz em diminuição de custos e incremento na produção.

De forma geral, os benefícios para as empresas e para os trabalhadores gerariam um aumento na produtividade geral da economia e, como conseqüência, um incremento no bem-estar social.

Pode-se, assim, observar que o efeito do incentivo fiscal é, primeiramente, um aumento no desempenho econômico da empresa seguido de um aumento na produtividade da economia e do bem-estar social.

Roesch (1984) concluiu que o incentivo fiscal do programa de formação profissional estaria levando a uma tendência de beneficiar as empresas mais lucrativas, considerando o período de 1976 a 1980. 
Em continuidade à sua pesquisa anterior, Roesch (1990) avaliou o impacto do programa de treinamento em uma amostra composta por 44 empresas do Rio Grande do Sul, considerando o período de 1976 a 1982. Ao contrário da expectativa do governo, que o programa de incentivos ao treinamento seria um instrumento de desconcentração da renda regional, foi observado que a distribuição das empresas beneficiárias, de fato, reproduz a estrutura de concentração do setor produtivo do país com 63\% das empresas beneficiárias se localizando na região sudeste, $26 \%$ na região sul e os restantes $11 \%$ nas demais regiões.

Na mesma linha do que foi detectado no primeiro estudo, o autor identificou que o uso dos incentivos aumenta com o tamanho médio do estabelecimento, indicando que o programa tende a beneficiar, primariamente, as grandes empresas, como, aliás, segundo Roesch (1990), acontece, também, com outros programas operados mediante de incentivos fiscais.

A sua conclusão é de que os incentivos fiscais não são o instrumento mais apropriado para operar o programa de formação profissional, em virtude de que não provocaram despesas adicionais com treinamento pelas empresas, além daquelas que elas estariam dispostas a incorrer na ausência do programa.

$\mathrm{Na}$ área da cultura, os incentivos fiscais doações e patrocínios motivaram o estudo de Durand et al. (1997) com o objetivo de localizar pontos de afinidade entre o evento ou o bem cultural para o qual se procurava recursos e a posição que a empresa ocupava ou pretendia ocupar no mercado, em termos de tamanho, ramo de atividade e perfil de público consumidor.

Os autores afirmam que a primeira lei de incentivos fiscais à cultura foi de nível federal, de autoria de José Sarney, apresentada ao Congresso Nacional em 1972 e aprovada somente em 1986 e ficou conhecida como Lei Sarney. O incentivo cultural contava com benefícios tributários aos doadores e patrocinadores de eventos culturais assegurados por lei como, por exemplo, dedução do imposto de renda.

As principais áreas que se apresentaram como concorrentes à área de cultura na disputa pela verba institucional de reforço de imagem foram: esporte, meio ambiente, assistência social e educação, ciência e tecnologia. 
O total captado da Lei Sarney, durante a sua vigência, foi da ordem de 450 milhões de dólares, mas não se conhece a distribuição desses recursos segundo sua origem ou destino.

Durand et al. (1997) afirmam que todas as leis de incentivos fiscais, inclusive a Lei Sarney, foram revogadas em março de 1990 pelo presidente Collor. Em meados de 1991 foi aprovada uma nova lei de incentivo fiscal à cultura por meio da Lei 8.313/91, conhecida como Lei Rouanet. Da mesma forma que a Lei Sarney, a Lei Rouanet, criou benefícios fiscais para os contribuintes do imposto de renda que apoiassem projetos culturais sob a forma de doação ou patrocínio.

A partir de 1995, o Ministério da Cultura delegou a análise, a aprovação e o acompanhamento de projetos a Estados e Municípios. Assim, além do incentivo de dedução do imposto de renda, em nível federal, os Estados passaram a conceder o benefício fisscal de dedução do Imposto sobre Operações relativas à Circulação de Mercadorias e sobre a Prestação de Serviços de Transportes Interestadual e Intermunicipal e de Comunicação (ICMS) e, os Municípios, passaram a conceder dedução do Imposto Sobre a Propriedade Territorial Urbana (IPTU) e do Imposto sobre Serviços de Qualquer Natureza (ISSQN).

Ressalte-se que a intenção das leis de incentivo é estimular as empresas a mobilizarem uma parcela de seus recursos próprios no apoio a projetos culturais e, assim, abater um percentual de algum imposto a pagar. A participação dos recursos próprios varia entre 20 e $30 \%$ do custo de cada projeto, o que significa dizer que uma empresa só pode custear até $80 \%$ de um projeto com recursos que terão isenção fiscal.

A conclusão de Durand et al. (1997) é que a maioria das leis de incentivos culturais não produziu resultados reais em intensidade que permitam uma avaliação. Entretanto, na cidade de São Paulo, a Lei Marcos Mendonça, no primeiro ano de funcionamento, 1991, repassou para os produtores culturais cerca de 270 mil dólares de um total disponível de oito milhões de dólares. Três anos depois, em 1994, seus resultados apresentavam um considerável aumento, tendo consumido 6,5 milhões de dólares de um total de 19,5 milhões de dólares disponíveis.

Com relação aos financiadores, a conclusão é de que cresceu o número de empresas que aderem às leis de incentivo fiscal à cultura. Em lugar dos poucos e tradicionais financiadores 
- grandes bancos privados ou públicos, empresas de petróleo, tabaco e bebidas, empreiteiras pode-se ver um rol ampliado de setores, incluindo empresas de ônibus ou de limpeza pública, estacionamentos, papelarias, gráficas e editoras, fábricas de instrumentos musicais, escolas particulares e hotéis apoiando os projetos culturais.

Relativamente ao setor de exportação, Ponciano e Campos (2003) avaliaram os impactos da eliminação de impostos nas exportações brasileiras, utilizando um modelo computável de equilíbrio geral para simular a reação dos agentes econômicos a essas mudanças. O objetivo foi avaliar os efeitos da desoneração fiscal sobre as exportações das atividades agropecuárias e agroindustriais no comportamento da economia, principalmente no que diz respeito á redução do déficit comercial.

A competitividade das atividades exportadoras brasileiras tem sido penalizada por distorções do sistema tributário, as quais contribuem para compor o chamado "Custo Brasil". Com vistas a alcançar maior competitividade, as empresas tentam auferir benefícios fiscais que estão condicionados ao cumprimento de determinadas metas, tais como: geração de empregos, aumento da produtividade e ampliação das exportações. Assim, as atividades mais competitivas ou que possuem maior capacidade de exportação são aquelas que deveriam receber maiores incentivos fiscais do governo.

O efeito da desoneração fiscal nas atividades de exportação deve ser diferenciado, dada a inserção relativa de cada atividade doméstica na economia mundial. Quando uma atividade nacional tem participação elevada na quantidade total da mercadoria transacionada no mercado internacional, variações em sua oferta influenciam a formação de seus preços, assim, esse país é um price maker nesse setor. Na situação inversa, o país é considerado um price taker, e o preço é definido pelo comportamento da oferta e da demanda no mercado externo.

Nos mercados em que o país atua como price maker o ganho de rentabilidade, devido á desobrigação fiscal, tende a ser passado ao consumidor externo, o que torna essa atividade mais competitiva. A tendência é o aumento do volume exportado, em razão do deslocamento de concorrentes por meio do crescimento da competitividade nesse mercado. O café e o suco de laranja brasileiros podem ser enquadrados nesse tipo de produto, pelo fato de o Brasil ainda ser o maior exportador mundial tanto de café quanto de suco de laranja. Portanto, nesse 
último caso espera-se maior receita total nessas atividades em razão da expansão da exportação, mesmo a preços decrescentes.

As estimativas da variação equivalente foram empregadas para avaliar os efeitos de alterações na incidência de impostos nas exportações. A variação equivalente refere-se á quantia adicional de renda monetária, aos preços relativos do equilíbrio inicial, necessária para manter inalterado o nível de bem-estar dos consumidores, quando eles alcançam diferentes níveis de utilidade, aos preços relativos dados pelas soluções de equilíbrio alternativas.

Ponciano e Campos (2003) concluíram que a eliminação dos impostos sobre as exportações dos produtos agropecuários, em separado ou em conjunto com as exportações dos produtos agroindustriais, produz um pequeno efeito recessivo sobre o nível da atividade econômica brasileira, com queda no nível de renda das famílias, que, por sua vez, diminuem os gastos com o consumo de alimentos e na receita do governo. A eliminação do imposto sobre as exportações dos produtos da agropecuária e das agroindústrias têxtil, adubos e café torna essas atividades mais competitivas no mercado externo. A eliminação dos impostos de exportação sobre os produtos agropecuários provoca redução considerável no desemprego rural, dada à expansão das exportações de produtos dessa atividade. Constataram, no entanto, aumento no desemprego urbano, em virtude da queda no nível de outras atividades, principalmente na maioria das agroindústrias processadoras de matéria-prima de origem agrícola. Finalmente, a queda no nível de renda das famílias resulta na diminuição do consumo de alimentos, o que, conseqüentemente, promove reduções nos níveis de bem-estar dos consumidores para todos os cenários que desoneram as exportações.

A ocorrência desses efeitos em sentido contrário, redução do bem-estar dos consumidores domésticos e aumento das receitas com as exportações, implicam que a sociedade deve escolher, em dado momento, o rumo da orientação política a ser seguido nas suas relações com o exterior.

Relativamente ao setor automobilístico, Guarnieri (2008) analisou as vantagens logísticas e tributárias obtidas com a implantação do RECOF. A quebra de barreiras alfandegárias, que conduz as empresas à intensificação do comércio exterior, exige maior desburocratização dos processos aduaneiros, visando à redução de custos logísticos e tributários. O Brasil abriga, 
atualmente, os principais grupos mundiais do segmento automobilístico, o que incrementa as exportações no setor.

Recente estudo do Banco Mundial demonstra que, enquanto, os produtos brasileiros levam em média 39 dias para serem liberados, no restante do mundo esse trâmite é de apenas 27 dias. Com a finalidade de reduzir a burocracia, facilitando as importações e incentivando as exportações, o governo brasileiro instituiu, por meio do Decreto-lei no 2.412 , de 03 de dezembro de 1997, o Regime Aduaneiro Especial de Entreposto Industrial sob controle Informatizado - RECOF. Mediante a IN SRF no 254 de 11 de dezembro de 2002, o regime foi expandido para o setor automobilístico, proporcionando uma série de vantagens. As principais vantagens proporcionadas por esse regime são representadas pela redução dos custos logísticos e do capital de giro empregado no pagamento de impostos incidentes na compra de matérias-primas e insumos.

Quanto à área da saúde, Sayd (2003) analisou o impacto da adoção de renúncia fiscal para o financiamento setorial, decorrente do abatimento das despesas com saúde da base de cálculo do imposto de renda de pessoas físicas, sob a ótica da equidade na distribuição federativa de recursos financeiros para a saúde. O objetivo foi demonstrar como a renúncia fiscal aumenta o grau de iniqüidade na distribuição de recursos regionais, quando considerados os valores referentes à renúncia fiscal no imposto de renda da pessoa física com despesas médicas no setor privado, entendidos como gasto tributário. $\mathrm{O}$ estudo foi feito a partir das deduções concedidas no Imposto de Renda da Pessoa Física (IRPF) constante das declarações entregues em 1999.

A renúncia fiscal motivada pelas deduções com gastos em saúde visa a isentar de tributação os rendimentos que se destinaram ao pagamento de despesas relacionadas a necessidades básicas dos contribuintes. Dessa forma, transforma-se numa espécie de assistência financeira governamental via sistema fiscal, em que ao invés de o Estado prover assistência financeira diretamente a esses contribuintes, opta por não arrecadar os tributos de seus rendimentos ou de parte deles, estimulando, assim, a parceria com o setor privado para a cobertura assistencial da população.

Embora a isenção tenha como objetivo aliviar de tributos aqueles cujos rendimentos são mais baixos, Sayd (2003) verificou que a própria regra de aplicação do cálculo para apuração do 
valor do imposto, por si só, já favorece os contribuintes que se encontram nas maiores faixas de alíquota. Quanto maior o rendimento, maior será a faixa de alíquota, por sua vez possivelmente maior será a despesa com saúde, conseqüentemente a renúncia fiscal, também, será mais elevada. Em outras palavras, isso quer dizer que a assistência financeira que o governo está propiciando por meio da renúncia fiscal está favorecendo a população cujos rendimentos são maiores.

Enquanto o valor médio da renúncia fiscal para os declarantes que estão incluídos na faixa de alíquota de $15 \%$ é de $\mathrm{R} \$ 152,71$, para os que estão na alíquota de $27,5 \%$ é de $\mathrm{R} \$ 771,85$. Por outro lado, a participação relativa de declarantes na faixa de alíquota de $15 \%$ é de $44,55 \%$ enquanto na de $27,5 \%$ é de $31,22 \%$.

Sayd (2003) concluiu que a renúncia fiscal motivada pelas deduções com despesas em saúde apresenta um perfil regressivo que beneficia mais a população cujos rendimentos se encontram nas faixas de renda superiores. Ao contrário do efeito desejado, a renúncia fiscal não está beneficiando mais a camada da população menos favorecida economicamente, comprometendo o critério de eqüidade no tratamento tributário na medida em que esse tipo de benefício sequer chega a atingir aqueles cuja capacidade contributiva é menor e que mesmo assim apresentaram gastos com despesas em saúde.

Apesar de o governo explicitar sua intenção em "proteger" a camada da população mais carente e amenizar a carga tributária daqueles que têm necessidade de incorrer em maior dispêndio com atendimento médico (DAIN et al., 2002), pode-se observar que a população economicamente mais favorecida é a que mais se beneficia com a renúncia fiscal.

Outra conclusão é que a partir da renúncia fiscal por despesas com saúde, o governo está provendo financeiramente, por meio do sistema tributário, a iniciativa privada do setor saúde, aumentando, significativamente, o grau de regressividade no financiamento setorial entre as unidades federativas. As regiões Norte e Nordeste são as menos favorecidas pelos recursos do Ministério da Saúde e também são as que apresentam piores indicadores socioeconômicos e epidemiológicos. (PORTO, 1997). No entanto, são as que, também, menos se beneficiam da renúncia físcal.

Outro agravante que Sayd (2003) destaca é o fato de os gastos tributários referentes à renúncia fiscal por despesas com saúde poderem estar sendo compensados por outras formas de 
arrecadação em que contribuintes que não são sujeitos aos benefícios que geram a renúncia fiscal estariam sendo tributados por outras vias.

Ainda no setor da saúde, Dain (2007) analisou a evolução do Sistema Único de Saúde - SUS do ponto de vista de seu padrão de financiamento, integrando as suas várias dimensões. Com essa intenção, são destacadas as relações entre a política fiscal e da seguridade social, o conjunto das relações intergovernamentais e, finalmente, as relações entre o setor público e o setor privado.

O trabalho destaca, também, a esfera das relações público-privadas no campo da saúde, na qual floresce o espaço da renúncia de arrecadação, ou do financiamento indireto pelo Estado, de planos e seguros de saúde. Esses são incentivados por tratamentos tributários favorecidos a pessoas físicas e jurídicas, assim como aos próprios sistemas de saúde supletiva, sem que se possa dar visibilidade orçamentária a tais gastos indiretos do Estado. Além do mais, a ausência ou insuficiência de regulação desse segmento compromete a política nacional de saúde.

Dain (2007) destaca que a elevação da carga global (de 29\% do PIB em 1998 para 35,9\% do PIB em 2006) foi fortemente influenciada pela evolução das contribuições sociais indiretas, que tiveram como efeito adicional a recuperação da participação federal na receita tributária disponível aos níveis dos anos 60. Os incentivos tributários, ou renúncia de arrecadação, pelo qual o setor público financia indiretamente o setor privado, não tornam imediatamente evidentes os setores e ações beneficiadas por tais despesas tributárias, evitando enfrentamentos frontais e uma real explicitação das prioridades de gasto público. Em sociedades muito desiguais como o Brasil, essa estratégia pode abrigar uma escolha trágica e silenciosa entre os que terão acesso a serviços e os que serão mais uma vez excluídos.

Do ponto de vista do financiamento, o sistema nacional de Ciência e Tecnologia, ao qual o SUS se integra, já utiliza mecanismos de indução, como incentivos fiscais; investimentos em pesquisa e desenvolvimento; créditos subsidiados, além da intervenção direta do Estado no processo produtivo e na formação de parcerias público-privadas.

A conclusão de Dain (2007) é que o gasto em saúde não deve ser sinônimo de desperdício de recursos, ou seja, os gestores da saúde, em todos os níveis de governo, devem zelar pela 
qualidade de seu gasto e pela racionalização e redução de seus custos. Mais ainda, devem atuar na revisão dos mecanismos de renúncia fiscal e outras formas de financiamento público ao setor supletivo de saúde, de modo a criar contrapartidas e reforçar o papel da regulação estatal sobre o sistema de saúde como um todo. Em função de seu impacto macroeconômico sobre a renda, o emprego, o produto nacional e o gasto público, o SUS e o Estado podem usar os mecanismos de financiamento direto e indireto ao setor privado para estimular ações no campo do desenvolvimento industrial e da inovação tecnológica, com impacto positivo na competitividade da indústria nacional e a garantia de oferta de insumos, medicamentos e equipamentos de Saúde, democratizando o acesso da população aos bens e serviços necessários à sua sobrevivência saudável e digna.

Relativamente ao setor agrícola, Aguiar e Monteiro (2005) estudaram o Cerrado do Piauí com o objetivo de verificar se a exploração granífera, especialmente a soja, tem contribuído para o desenvolvimento sustentável da região do ponto de vista ambiental, econômico e social. A pesquisa fundamentou-se em levantamento da documentação bibliográfica e estatística realizado em instituições vinculadas, direta ou indiretamente, às questões ambientais e agrícolas existentes no País, no Estado e no Município de Uruçuí. Do universo de 39 empresas agrícolas existentes em Uruçuí, entre os anos de 2002 e 2004, 31 constituíram a amostra, correspondendo a $77 \%$ do total de empreendimentos agrícolas. Desse total, dois recusaram-se a responder os questionários, resultando numa amostra final de 29 empreendimentos.

Dentre os principais programas que promoveram a capitalização da agricultura no Cerrado, o incremento da produção e da produtividade destaca-se: o Programa de Cooperação Nipobrasileira de Desenvolvimento dos Cerrados (PRODECER) e o Programa de Desenvolvimento dos Cerrados (POLOCENTRO). No Estado do Piauí, as principais políticas públicas voltadas para a ocupação e desenvolvimento do Cerrado tiveram início na década de 1970, instituídas pelo Governo Federal, mediante o Decreto-lei no 1.376 , de 12.12.74, que criou, entre outros, o Fundo de Investimento do Nordeste - FINOR e o Fundo de Investimentos Setoriais - FISET, ambos com incentivos fiscais de dedução do imposto de renda. O primeiro foi um investimento de cunho regional; o segundo, um investimento setorial. Todavia, ambos objetivavam desenvolver as regiões e os setores considerados frágeis economicamente. 
A conclusão do estudo sinaliza que para ter sustentabilidade, a agricultura moderna deve se nortear por um padrão que tenha como referência o uso racional da terra e dos recursos bióticos, florestais, que possam permanecer por longo tempo na natureza. Faz-se necessário que a preocupação ambiental realmente converta-se em um instrumento de mudanças para que a produção agrícola venha a se tornar sustentável no município. Para que isso se concretize, é preciso que essa produção esteja alicerçada nos preceitos do desenvolvimento sustentável, que considera as dimensões social, econômica e ecológica como o tripé do desenvolvimento sustentável.

Um estudo não propriamente sobre incentivos fiscais, mas que os apontou como um dos fatores de influência no resultado apurado, foi desenvolvido por Anuatti-Netto et al. (2005) que avaliaram o efeito da privatização sobre as empresas privatizadas no Brasil. A amostra foi composta por todas as empresas do setor produtivo privatizadas desde 1991, examinando um conjunto de 15 (quinze) indicadores de desempenho com utilização da análise de dados em painel.

Os resultados indicaram uma clara queda da razão entre imposto de renda e receita líquida (IR/RL). Em todas as análises os coeficientes são negativos e estatisticamente significativos. Os autores afirmam que há duas explicações para esse resultado. O imposto devido é apurado como a diferença entre os tributos calculados e as deduções permitidas, embora essas últimas não constituam subsídios explícitos. Os autores ressaltam que entre as categorias gerais de deduções aplicáveis se encontram os incentivos fiscais.

A conclusão do estudo é que houve um aumento na lucratividade e na eficiência operacional, um aumento na liquidez e uma redução no endividamento de longo prazo das empresas da amostra.

Relativamente aos incentivos no setor público, Davies (2006) examinou o FUNDEF e o FUNDEB, que são mecanismos para redistribuir, dentro de cada Estado, entre o governo estadual e as prefeituras, uma parte dos impostos (15\% de alguns, no caso do FUNDEF, e 20\% de um número maior de impostos, no caso do FUNDEB) já vinculados à manutenção e desenvolvimento do ensino pela Constituição Federal de 1988, com base no número de matrículas no ensino fundamental regular (o FUNDEF) e na educação básica (o FUNDEB). A participação federal dar-se-ia com uma complementação aos fundos estaduais cujo valor per 
capita não alcançasse o valor mínimo nacional, destinado a garantir um padrão mínimo de qualidade. $\mathrm{O}$ artigo enfatiza algumas das deficiências dos dois fundos, como a de que eles trazem poucos recursos novos para o sistema educacional como um todo, pois a complementação federal (que seriam esses recursos novos) foi insignificante no caso do FUNDEF e não será significativa no caso do FUNDEB. Outra deficiência é que, na redistribuição dos recursos dentro de cada Estado, uns governos ganham, mas outros perdem na mesma proporção e a conseqüência é que só os que ganham e/ou recebem a complementação têm mais chances de manter e desenvolver o ensino e valorizar o magistério.

Ainda, no âmbito de incentivos ao setor público, Prado Filho e Sobreira (2007) avaliaram os sistemas de reciclagem e de disposição de resíduos sólidos domésticos que possuem incentivos fiscais definidos pela Lei Estadual n- 13.803/2000 de Minas Gerais. A pesquisa buscou avaliar o desempenho operacional qualitativo e analisar os ganhos ambientais advindos da implantação da chamada Lei Robin Hood de Minas Gerais, no que se refere à destinação final e aos sistemas de reciclagem e compostagem de Resíduos Sólidos Urbanos RSU implantados em municípios habilitados no ICMS Ecológico mineiro. Ao todo foram estudadas 20 unidades de triagem e compostagem de resíduos domésticos das que receberam recursos do ICMS Ecológico até dezembro de 2003. A pesquisa foi desenvolvida por análise de documentação de licenciamento ambiental de aterros sanitários e usinas de reciclagem e compostagem de resíduos financiados pela referida lei e por visitas às unidades sanitárias, sendo usados os instrumentos metodológicos da agência ambiental do Estado de São Paulo (Companhia de Tecnologia de Saneamento Ambiental - CETESB) que avaliam as condições de instalação e operação desses tipos de empreendimentos.

Em Minas Gerais, a Lei Estadual no 12.040/95, substituída posteriormente pela Lei 13.803/2000, incentiva as administrações municipais a buscar soluções para os problemas socioambientais que se relacionam com os RSU. Tal instrumento legal define a redistribuição aos municípios de parcela de um quarto da receita arrecadada pelo Imposto sobre Operações Relativas à Circulação de Mercadorias e sobre Prestações de Serviços de Transporte Interestadual e Intermunicipal e de Comunicação (ICMS), permitindo que eles se beneficiem desses recursos, por meio da apresentação de projetos em várias áreas, inclusive meio ambiente e saneamento. 
Com essa Lei, o repasse de parte dos $25 \%$ do total arrecadado pelo Estado e pertencente aos municípios, como definido pelo inciso II do parágrafo único do artigo 158 da Constituição Federal, não leva em conta a arrecadação de cada um deles, mas os investimentos realizados pelas prefeituras em saúde, educação, meio ambiente e saneamento, agricultura e preservação do patrimônio histórico e cultural. Por conta disso, a referida Lei passou a ser conhecida como Lei Robin Hood e Lei do ICMS Ecológico, pois uma fatia maior da receita arrecadada pelo Estado pode ser destinada a municípios pobres, desde que esses apresentem projetos e propostas nas áreas especificadas acima. Prado Filho e Sobreira (2007) explicam que Minas Gerais foi o primeiro Estado brasileiro a conceder esse tipo de incentivo para investimentos no campo do saneamento ambiental.

Do estudo, constataram que o incentivo de Minas Gerais, definido pela Lei do ICMS Ecológico, traz importantes benefícios ambientais aos municípios, embora ainda seja reduzido o número dos contemplados por esse fomento à gestão dos resíduos sólidos urbanos. Concluíram, também, que algumas das unidades estudadas apresentam problemas de natureza ambiental e operacional. Apesar das deficiências constatadas, é possível afirmar que o apoio do ICMS Ecológico, na modalidade tratamento e disposição dos resíduos sólidos domésticos, atende satisfatoriamente aos objetivos propostos, atestando o acerto, por parte de Minas Gerais, na implementação de um sistema de gestão ambiental de RSU calcado no chamado princípio do tipo protetor-recebedor.

Em decorrência do contexto macroeconômico, Pochmann (2007) preocupou-se em analisar, inicialmente, seus entraves derivados do processo de financeirização da riqueza predominante no país. Em seguida, buscou interpretar previamente a evolução recente tanto do gasto social do governo federal como do padrão adotado de ajuste fiscal. Por fim, considerou as implicações da política social sobre o nível de emprego e a desigualdade da renda derivada do trabalho, tendo como referência as políticas de elevação do salário mínimo e de difusão da garantia de rendimento no Brasil.

Ele afirma que não obstante a elevação da carga tributária, verificou-se a contração e a alteração na composição do gasto público. Como não poderia deixar de ser, o esforço fiscal terminou resultando em maior constrangimento, não apenas ao combate sistemático da desigualdade social, mas à expansão das atividades econômicas. Não obstante o enorme custo social imposto pela perda de dinâmica da acumulação produtiva no Brasil, assiste-se, também, 
ao constante avanço do bloqueio à universalização das políticas de saúde, educação, habitação e saneamento, cultura, transporte, trabalho entre outras. $\mathrm{O}$ aumento da tributação constitui uma das principais medidas do padrão de ajuste das finanças públicas. Durante a década de 1980, por exemplo, o total da arrecadação tributária representava cerca de $22 \%$ de todo o Produto Interno Bruto. Nos anos 90, a carga tributária em relação ao PIB passou a ser de 27,8\%. Em 2004, a carga tributária bruta correspondeu a 34,1\% do PIB. Em duas décadas, a carga tributária bruta subiu cerca de doze pontos percentuais. Como a base da tributação é de natureza regressiva no Brasil, pois se assenta no imposto indireto, ele conclui que o adicional de arrecadação pública concentrou-se justamente na parcela mais pobre da população. Mesmo pagando mais impostos, os bens e serviços públicos não foram universalizados, nem mesmo corresponderam à elevação generalizada de sua qualidade, uma vez que o adicional de recursos dirigiu- se, na maioria das vezes, ao atendimento dos compromissos do Estado para com os detentores dos direitos sobre a riqueza financeirizada.

Em resumo, Pochmann (2007) concluiu que a ação das políticas públicas adotadas com a Constituição Federal de 1988 é necessária na luta contra a pobreza, porém insuficiente, até o presente, para compensar o movimento mais geral de esvaziamento da renda do trabalho a que o Brasil encontra-se submetido desde o abandono do ciclo de industrialização nacional, em 1980.

Relativamente aos incentivos fiscais para pesquisa e desenvolvimento, Formigoni et al. (2008) realizaram estudo nas empresas participantes do Programa de Desenvolvimento Tecnológico Industrial (PDTI) de forma a conhecer a relação existente entre os benefícios fiscais provenientes do PDTI e o Desenvolvimento Socioeconômico (DSE) proporcionado pela empresa, por meio de uma proxy estabelecida para DSE, com a finalidade de permitir uma avaliação pelas partes envolvidas nesses projetos, ou seja, governo, empresas e sociedade. Consideraram que os incentivos fiscais, tais como: isenção, subvenção, crédito presumido, redução de base de cálculo, redução de alíquota, subsídios acarretam diminuição de receita para o Governo, mas, por outro lado, esses incentivos fiscais visam a promover o desenvolvimento de determinadas regiões ou setores e, portanto, torna-se importante ter-se alguma medida de avaliação do retorno desses "investimentos" que o Governo realiza. Os resultados evidenciaram que não existe relação, estatisticamente significativa, entre os benefícios decorrentes do PDTI e o desenvolvimento socioeconômico dos funcionários das empresas incentivadas, não confirmando a hipótese de pesquisa adotada de que os 
investimentos em tecnologia realizados pelas empresas beneficiadas pelo incentivo fiscal para a capacitação tecnológica industrial, afetam positivamente o desenvolvimento socioeconômico de seus funcionários, em contrapartida dos benefícios que as empresas usufruíram por meio dos incentivos fiscais, os quais diminuíram os recursos disponíveis que seriam aplicados na melhoria da qualidade de vida da população.

O Quadro 4 apresenta uma síntese das pesquisas realizadas no Brasil sobre os incentivos fiscais e consideradas neste estudo. 
Quadro 4 - Síntese das pesquisas sobre incentivos fiscais realizadas no Brasil e consideradas neste estudo

\begin{tabular}{|c|c|c|}
\hline Autor & Pesquisa no Brasil & $\begin{array}{c}\text { Conclusão } \\
\end{array}$ \\
\hline Santos e Candiota (1974) & $\begin{array}{l}\text { Incentivo fiscal de isenção do } \\
\text { imposto de renda sobre o lucro das } \\
\text { sociedades de crédito imobiliário. }\end{array}$ & $\begin{array}{l}\text { O incentivo fiscal acarreta: } \\
\text {-maior crescimento da empresa e } \\
\text { - aumento da rentabilidade. }\end{array}$ \\
\hline Roesch (1984) & $\begin{array}{l}\text { Incentivo fiscal para formação } \\
\text { profissional de empregados }\end{array}$ & $\begin{array}{l}\text { O incentivo fiscal: } \\
\text { - aumenta o desempenho econômico da } \\
\text { empresa; } \\
\text { - beneficiou as empresas mais lucrativas; } \\
\text { - privilegiou mais as grandes empresas. }\end{array}$ \\
\hline Durand et al. (1997) & Incentivos fiscais à cultura & $\begin{array}{l}\text { - os resultados apurados não } \\
\text { possibilitaram uma avaliação dos seus } \\
\text { efeitos; } \\
\text { - foram repassados somente } 33 \% \text { do total } \\
\text { de recursos disponíveis de incentivos. }\end{array}$ \\
\hline Sayd (2003) & Incentivos fiscais à saúde & $\begin{array}{l}\text { - o incentivo fiscal beneficia a população } \\
\text { com faixa de renda superior em } \\
\text { detrimento da população mais carente; } \\
\text { - as Regiões Norte e Nordeste foram as } \\
\text { menos favorecidas por recursos embora } \\
\text { tenham sido as que apresentaram os } \\
\text { piores indicadores socioeconômicos e } \\
\text { epidemiológicos. }\end{array}$ \\
\hline Aguiar e Monteiro (2005) & $\begin{array}{l}\text { Programas PRODECER e } \\
\text { POLOCENTRO }\end{array}$ & $\begin{array}{l}\text { - os incentivos fiscais não foram } \\
\text { suficientes para manter a } \\
\text { sustentabilidade da produção agrícola. }\end{array}$ \\
\hline Anuatti-Neto et al. (2005) & Privatização empresas brasileiras & $\begin{array}{l}\text { A privatização acarretou redução do } \\
\text { imposto de renda e possibilitou: } \\
\text { - um aumento da lucratividade; } \\
\text { - redução no endividamento de longo } \\
\text { prazo. }\end{array}$ \\
\hline Davies (2006) & Programas FUNDEF e FUNDEB & $\begin{array}{l}\text { Os programas causaram desigualdade } \\
\text { dentro do Estado entre as prefeituras que } \\
\text { receberam e as que não receberam o } \\
\text { incentivo. }\end{array}$ \\
\hline Dain (2007) & $\begin{array}{l}\text { Relação entre a política fiscal e } \\
\text { seguridade social }\end{array}$ & $\begin{array}{l}\text { - o setor público não torna clara a } \\
\text { distribuição dos recursos para o setor } \\
\text { privado. }\end{array}$ \\
\hline Pochmann (2007) & $\begin{array}{l}\text { Política social x desigualdade de } \\
\text { renda }\end{array}$ & $\begin{array}{l}\text { São necessárias mais ações de políticas } \\
\text { públicas para a redução da pobreza. }\end{array}$ \\
\hline $\begin{array}{l}\text { Prado Filho e Sobreira } \\
\text { (2007) }\end{array}$ & $\begin{array}{l}\text { Incentivos fiscais sobre reciclagem e } \\
\text { disposição de resíduos sólidos } \\
\text { domésticos }\end{array}$ & $\begin{array}{l}\text { O incentivo trouxe importantes } \\
\text { benefícios ambientais }\end{array}$ \\
\hline Formigoni et al. (2008) & Programa PDTI & $\begin{array}{l}\text { Não confirmaram a hipótese de que os } \\
\text { investimentos em tecnologia realizados } \\
\text { pelas empresas afetam positivamente o } \\
\text { desenvolvimento socioeconômico dos } \\
\text { seus funcionários. }\end{array}$ \\
\hline Guarnieri (2008) & Programa RECOF & $\begin{array}{l}\text { - o programa propiciou redução de } \\
\text { custos logísticos e do capital de giro } \\
\text { empregado no pagamento de impostos }\end{array}$ \\
\hline Ponciano e Campos (2003) & Incentivos fiscais à exportação & $\begin{array}{l}\text { O incentivo fiscal: } \\
\text { - torna as atividades mais competitivas } \\
\text { no mercado externo; } \\
\text { - reduz o bem-estar dos consumidores. }\end{array}$ \\
\hline
\end{tabular}


Em linhas gerais, pode-se verificar que os estudos realizados no Brasil, praticamente, focam um determinado incentivo e seus efeitos macroeconômicos.

\subsubsection{Estudos sobre incentivos fiscais realizados no exterior}

De forma a se apresentarem alguns estudos realizados no exterior, é necessário observar a interpretação de alguns termos empregados na literatura americana de acordo com Simões (1989):

- $\quad$ Grant $=$ concessão; doação; subvenção: concessão de um direito por autoridade legal, como no caso de uma patente ou a alocação de verbas como doação para um fundo de pesquisa. Também pode ser a transferência de propriedade por meio de uma escritura.

- Government grants = subvenção governamental.

- Tax advantage = vantagem tributária: diminuição no imposto de renda pago ou a pagar, em conseqüência de melhor interpretação das entrelinhas da lei.

- $\quad$ Tax allowance $=$ dedução tributária: montante que pode ser deduzido do imposto de renda.

- $\quad$ Tax avoidance = benefício tributário: tentativa legal de reduzir a carga de um imposto, sendo exploradas ao máximo as discrepâncias e pontos omissos porventura existentes na legislação tributária.

- Tax base erosion = erosão de base tributária: diminuição da base do imposto por meio de aumento no tratamento preferencial dado a certos grupos, em geral criando isenções especiais e reduzindo alíquotas.

- $\quad$ Tax benefit = benefício tributário.

- $\quad$ Tax equity = eqüidade tributária: esforço das autoridades fiscais para que a carga tributária do imposto de renda seja distribuída eqüitativamente entre os vários contribuintes.

- Tax evasion = sonegação tributária: tentativa propositada de um indivíduo ou firma de fraudar as autoridades tributárias, não declarando ou fornecendo dados falsos em sua declaração de imposto de renda.

- $\quad$ Tax exclusion = renda não tributável: providência legal que permite aos contribuintes do imposto de renda excluir tipos especificados de renda. Na renda não tributável, em alguns países figuram as pensões dos veteranos, benefícios previdenciários, presentes, heranças. 
- $\quad$ Tax exempt bonds = obrigações isentas de imposto: nos Estados Unidos, títulos de dívida (securities) emitidos por Estados, cidades e outras autoridades públicas, consoante a lei federal, cujos juros são total ou parcialmente isentos do imposto de renda.

- $\quad$ Tax exemption = isenção tributária ou fiscal: isenção de taxas, impostos e contribuições para determinados tipos de negócios ou propriedades. Os principais beneficiados são certas entidades educacionais e religiosas. Alguns valores públicos, também, estão isentos. A isenção, muitas vezes, é instrumento de poder político de alguns grupos.

- $\quad$ Tax haven, tax shelter = paraiso fiscal: países cujos governos oferecem grandes vantagens no pagamento de impostos aos estrangeiros e às suas empresas, como a Suíça, Venezuela e outros.

- $\quad$ Tax immunity = imunidade tributária.

- $\quad$ Tax incentive = incentivo fiscal: providência fiscal destinada a encorajar os meios de produção do país e assim conseguir mais atividade econômica. Alguns incentivos podem ter a forma de isenção ou renda não tributável.

- $\quad$ Tax loophole = omissão fiscal: falha ou omissão na legislação fiscal, da qual se aproveitam indivíduos ou grupos para a diminuição de sua carga tributária. Essa omissão está nas entrelinhas da lei. Às vezes, pode ser um dispositivo legal de benefício ao contribuinte que desempenha certas atividades. Também pode ser a legislação forçada por um grupo de pressão mediante trabalhos nos bastidores.

- $\quad$ Tax reference $=$ benefícios tributários: dispositivos de objetivo específico, alcançando um grupo relativamente restrito de contribuintes, setor ou região, e que, em princípio, poderiam ser substituídos por programas de gastos diretos.

- $\quad$ Tax relief = dedução tributária: quantia que pode ser descontada do total do imposto tributável, porque foi gasta de um modo especial. No Reino Unido, há dedução por hipotecas e certas espécies de seguro pessoal.

- $\quad$ Tax saving = redução de imposto.

- $\quad$ Tax shields = proteção de imposto, escudo fiscal.

Como se pode observar do acima exposto, os seguintes termos não têm relação direta com o desenvolvimento do presente estudo: tax advantage, tax allowance, tax avoidance, tax equity, tax evasion, tax exclusion, tax exempt bonds, tax haven, tax loophole, tax reference, tax relief, tax shelter. 
Assim, os termos utilizados na busca de artigos sobre o tema foram os seguintes: government grant, tax base erosion, tax exemption, tax immunity, tax incentive, tax reference.

Utilizando a base de dados do portal de periódicos da Capes, foi efetuada uma busca nos periódicos internacionais utilizando as expressões selecionadas. Considerando a evolução temporal do assunto, discorre-se, a seguir, sobre o que foi desenvolvido até o presente, considerando-se os trabalhos a que se teve acesso.

Sobre a isenção tributária, Guthmann (1951, p. 161) argumenta que ela é um fator que dá a certos tipos de negócios uma vantagem sobre seus concorrentes comerciais que pagam os impostos, afirmando que "A imunidade fiscal permite que a empresa reduza o preço ao consumidor e expanda mais rapidamente a partir dos lucros retidos." ${ }^{5}$ Guthmann (1951) analisa a isenção tributária como fator competitivo de negócios, por meio das cooperativas de consumidores, cooperativas de compra dos agricultores e cooperativas de comercialização dos agricultores. As duas primeiras, particularmente, são as que mais competem com outras empresas comerciais, com as quais têm diversas características comuns.

A atenção principal de Guthmann (1951) está voltada para a tributação do imposto de renda. Ele alerta que devido ao alto custo dos tributos, o governo deve ter muito cuidado para que os tributos não sejam usados para beneficiar algumas organizações empresariais em detrimento de outras. Guthmann (1951, p. 164) afirma, também, que, quando uma cooperativa é isenta do imposto de renda federal e opera sob condições semelhantes às de uma empresa normal, é possível pagar um dividendo ao patrocinador igual à percentagem de imposto sobre as vendas e, ainda, ter um ganho maior do que o lucro líquido total das corporações empresariais concorrentes normais. Ele ressalta que isso é, obviamente, uma vantagem concorrencial substancial.

Guthmann (1951, p. 161) conclui que:

Com o aumento substancial no peso dos impostos nos anos recentes, especialmente desde 1940, um tratamento fiscal diferenciado pode ser um fator decisivo para as empresas isentas de impostos, dando a elas uma vantagem em relação às outras tributadas, levantando a possibilidade, se não a

\footnotetext{
5 "Tax immunity permits a business to lower prices to the consumer and to expand more rapidly from retained earnings."
} 
certeza, de que as primeiras podem destruir as últimas, independentemente da sua eficiência comparativa. $^{6}$

Da mesma forma, Somers (1951) afirma que a isenção de impostos é uma poderosa arma de política econômica. Exemplificando os principais tipos de isenção fiscal, cita:

a) isenção do imposto sobre o rendimento pessoal inferior a certo nível;

b) isenção dos rendimentos de determinados títulos governamentais;

c) isenção parcial de taxas sobre propriedades concedidas a determinadas pessoas, tais como os veteranos;

d) isenção de impostos sobre propriedade concedida a empresas novas em algumas localidades;

e) isenção de impostos sobre propriedade ou impostos sobre a renda, ou ambos, concedidos às cooperativas, agências governamentais ou religiosos, instituições caritativas ou educacionais;

f) certas isenções concedidas a empresas que operam em países estrangeiros.

A preocupação de Somers (1951) está voltada às entidades isentas de impostos que estão envolvidas em negócios concorrentes com as empresas que estão sujeitas à tributação. A questão envolvida é se, e em que medida, a isenção fiscal dá às instituições isentas de impostos uma vantagem competitiva sobre as instituições que são tributadas.

O Internal Revenue Code - IRC prevê que os seguintes tipos de empreendimentos são isentos do imposto de renda federal: instituições sem fins lucrativos, como as caritativas, religiosas, instituições de ensino, ligas cívicas, clubes sociais e as cooperativas que operam com uma base de patrocinadores. O fator decisivo para a determinação da renda isenta é a finalidade explorada pela sociedade. O critério básico de tributação é se as atividades estão ou não relacionadas ao objetivo principal da corporação isenta dos impostos.

Sobre a afirmação de Guthmann (1951) de que a imunidade fiscal permite à empresa reduzir os preços ao consumidor e expandir mais rapidamente a partir dos lucros retidos, Somers (1951, p. 180) questiona se a empresa isenta de impostos irá mesmo decidir reduzir seus preços. Para ele, se o imposto permite uma redução nos preços é uma questão de aritmética;

\footnotetext{
6 "With the huge increase in the weight of taxes in recent years, especially since 1940, differential tax treatment can be a decisive factor in giving an exempt business such an advantage over the taxed business as to raise the possibility, if not the certainty, that the former may destroy the latter regardless of its comparative efficiency."
} 
mas se a empresa irá, realmente, praticar uma redução nos preços em virtude da isenção do imposto de renda é um assunto que remete, diretamente, à teoria da incidência e efeitos do imposto de renda das empresas. Somers (1951) alerta que se tem, primeiramente, que reconhecer o fato de que, em alguns casos, esse problema é acadêmico, já que as empresas isentas de impostos não concorrem no mesmo mercado que as empresas tributadas.

Somers (1951) afirma que a dimensão da vantagem competitiva, na prática, depende, parcialmente, da existência real da redução imediata do preço ou de se a redução de preço tomou a forma de patrocinar distribuição de dividendos posteriormente. Se o preço mais baixo das cooperativas assume a forma de um dividendo patrocinado, isto é, se o preço inicialmente cobrado é o mesmo que o das empresas tributadas, mas há um repasse no fim do ano, existe uma questão real como para qualquer vantagem competitiva. A questão é se um desconhecido e incerto dividendo patrocinado a ser pago ao final do ano tem o mesmo efeito que uma redução imediata no preço no momento em que a venda é feita.

Somers (1951) conclui que a perspectiva de um dividendo patrocinado, provavelmente, afete as compras, mas o efeito, dificilmente, é o mesmo que uma redução no preço, igual ao imposto de renda computado no final do ano, sobre as vendas que realmente ocorreram durante o ano. Um dividendo patrocinado pode ser considerado como uma redução do preço ex post e seus efeitos sobre as vendas não podem ser considerados como sendo os mesmos caso houvesse uma redução real no momento da venda. Isso é especialmente importante, uma vez que, na verdade, dividendos patrocinados, algumas vezes, não são pagos para todos.

Na opinião de Harriss (1954), embora a tributação tenha dominado o estudo das finanças públicas, os gastos públicos têm tido bem menos análises econômicas. Dessa forma, elaborou um estudo com o propósito de chamar a atenção para áreas importantes, estimular estudos e incentivar medições dos gastos governamentais. Três questões principais servem de base para pesquisa sobre os gastos governamentais:

1) Como o total dos gastos governamentais afeta o nível de renda e preços a nível nacional?

2) Quais são os resultados econômico, social e outros - estradas, hospitais, pensões - de diferentes tipos de gastos?

3) Como o governo pode gastar mais eficientemente? 
Isenções e semelhantes tipos de benefícios fiscais são concebidos para compensar, parcialmente, os efeitos de uma tributação específica e, em parte, para reduzir a necessidade de gastos. Harriss (1954) explica que existem isenções fiscais para renda e morte, doações e legados para organizações religiosas, artísticas, educativas e outras. Os benefícios fiscais são concedidos para incentivar atividades que não têm demonstrado inclinação para suportar seus gastos por conta própria.

Dessa forma, as empresas privadas beneficiadas têm a liberdade de utilizar os recursos que, de outro modo, iriam para o governo, que poderia utilizá-los de forma diferente ou, então, poderia diminuir os impostos sobre todas as empresas. O contribuinte, num certo sentido, recebe poderes para utilizar fundos governamentais.

Muito semelhante às isenções fiscais são as deduções de despesas no cálculo do imposto devido. Alguns tipos de despesas que são dedutíveis da base de cálculo do imposto, onde as taxas são elevadas, tomam um significado especial. A direção do gasto privado pode ser influenciada profundamente num mundo de elevadas taxas de imposto dependendo do que é dedutível como despesa na empresa.

Harriss (1954) afirma que nos EUA é muito difícil obter os dados necessários para determinar com razoável precisão os montantes das isenções de imposto sobre a renda, bens, vendas, morte e outros casos. Mas, alerta, os totais são grandes e, provavelmente, aumentarão. Como as taxas de impostos aumentam, o valor da isenção fiscal também aumenta. Na prática, porém, a política de subsídios, tal como a isenção, não é reexaminada quando mudanças nas taxas de imposto alteram o valor de uma isenção existente.

Por fim, Harriss (1954) ressalta que, embora a medição dos aspectos alocativos dos gastos públicos seja difícil, a consciência da existência de problemas podem permitir uma análise um pouco mais rigorosa do papel do governo na economia e um exame um pouco mais cuidadoso da utilização dos recursos em algumas ou em todas as características das despesas públicas.

Analisando as grandes cooperativas de crédito dos EUA, Croteau (1956) procurou determinar se existem diferenças qualitativas e/ou quantitativas entre elas, assim definidas aquelas que possuem ativos em valor superior a \$ 1 milhão. A palavra "grande" é um termo relativo; enquanto um banco ou uma indústria com apenas $\$ 1$ milhão de dólares em ativos sejam 
considerados pequenos, esse montante é relativamente grande para uma cooperativa de crédito. Os dados foram consolidados pela National Credit Union Management Conference para o encontro de Dayton em 1954 e apurados de uma amostra relativa a 103 grandes cooperativas de crédito.

Croteau (1956) concluiu que, na composição do balanço patrimonial, existem algumas diferenças entre grandes e pequenas cooperativas de crédito; as grandes cooperativas detêm um crédito proporcionalmente menor em quantidade de ativos em relação aos empréstimos a membros e em dinheiro e uma proporção um pouco menor de dívidas relativas a membros participantes. Uma análise das operações, no entanto, não apresentou qualquer diferença significativa entre as cooperativas de crédito de diferentes dimensões.

Nessa linha de pesquisa, Black e Dugger (1981) elaboraram um estudo sobre a estrutura da cooperativa de crédito, o estado do setor e o caráter evolutivo das instituições em relação às forças do mercado e regulamentares. A preocupação central dos autores está voltada à capacidade das cooperativas para absorver riscos de crédito devido às mudanças legais, regulamentares e concorrenciais. Eles afirmam que o vínculo comum da cooperativa é baseado na profissão, associação ou residência. As exceções aparecem nas leis estaduais e aplicam-se às instituições autorizadas pelo Estado. As cooperativas de crédito obtêm fundos de associados e não associados. Os empréstimos de não associados são chamados certificados de endividamento e não estão segurados. Relativamente aos produtos, as cooperativas de crédito podem oferecer contas de poupança, certificados de ações, contas de aposentadorias com proteção fiscal e partilhar projetos aos associados. Como resultado das legislações aprovadas nos EUA em 1976, 1978 e 1980, as associações de crédito foram autorizadas a oferecer serviços sob a forma de empréstimos com prazos mais longos, linhas de crédito, empréstimos com limites mais altos, empréstimos hipotecários de 30 anos e empréstimos de 15 anos para reforma da casa. Mesmo assim, o capital das cooperativas de crédito vem declinando a cada ano. O índice capital/ativo foi reduzido de 8\% em 1970 para 6,3\% no final de 1979. A promulgação do Ato de Controle Monetário e Desregulamentação de 1980, autorizando o pagamento de juros na transação de contas e de empréstimos a consumidores para instituições econômicas, aumentou a capacidade competitiva dos bancos e associações de poupança e empréstimo. 
Com relação aos subsídios federais, Gordon e Slemrod (1983) realizaram um estudo com o objetivo de explorar teoricamente e, em seguida, simular empiricamente os efeitos da eliminação de um dos dois seguintes subsídios federais que incentivam os gastos do governo local nos EUA:

1) direito à dedução do imposto de renda dos pagamentos de impostos locais e

2) isenção fiscal dos juros recebidos sobre os títulos municipais.

Gordon e Slemrod (1983) afirmam que os gastos das prefeituras nos EUA são subsidiados por uma variedade de fontes. Manifestamente, as leis fiscais tornam os juros recebidos pelos títulos municipais isentos de imposto e permitem que os pagamentos de impostos municipais sejam deduzidos do lucro tributável. Além disso, os proprietários de empresas comerciais e industriais e de propriedades imobiliárias, acabam pagando por uma moderada fração dos serviços públicos que beneficiam os moradores locais. Gordon e Slemrod (1983) concluíram que a supressão da dedutibilidade dos impostos locais suscita o interesse de todos os grupos de renda, dos proprietários de imóveis bem como dos locatários. Tornar os juros sobre os títulos municipais tributáveis, no entanto, substancialmente afeta os muito ricos, que perdem a proteção fiscal, e pode prejudicar os muito pobres, que pagariam mais pelos serviços municipais. Embora a maioria das pessoas ganhe, o ganho líquido é muito pequeno.

Ainda, na linha de pesquisa sobre as cooperativas de crédito, Barron et al. (1994) argumentam que as organizações envelhecem e ficam mais vulneráveis à competição das novas empresas, que são mais inovadoras e dinâmicas. Porém existe uma visão alternativa, que grandes organizações se beneficiam de vantagens surgidas da experiência, da habilidade de formarem parcerias e do exercício do poder de mercado.

Para examinar a relevância dessas hipóteses concorrentes, a idade é incluída como uma variável explicativa na análise multivariada. Uma variação de séries temporais da estrutura financeira da cooperativa de crédito e indicadores de desempenho são, igualmente, incluídos na análise multivariada. É esperado que um alto retorno sobre os ativos contribua positivamente para o crescimento da cooperativa de crédito. Também é utilizado o índice custo/receita (com custo definido como despesas operacionais) para capturar a eficiência operacional, onde um alto índice custo/receita sugere um desempenho ineficiente e poderá ter impacto negativo sobre o crescimento. O índice capital/total ativo é incluído, embora existam hipóteses contrastantes a respeito do relacionamento esperado com o crescimento. Uma 
possibilidade é que uma sólida base de capital é necessária para sustentar o crescimento do ativo, caso em que um relacionamento positivo é esperado. Alternativamente, a cooperativa de crédito com índices de capital acima da média podem estar operando com excesso de precaução, caso em que o crescimento de seu desempenho pode ser prejudicado.

As evidências estatísticas sugerem que:

a) A cooperativa de crédito que tem um crescimento acima da média num período experimenta um crescimento médio abaixo da média no período seguinte.

b) Pequenas cooperativas de crédito tendem a ter menor variabilidade no crescimento do que as cooperativas maiores.

c) Entre as cooperativas de crédito estaduais as grandes crescem mais rápido do que as pequenas. No caso das cooperativas de crédito federais ocorre o inverso.

d) A idade aparece como restritiva do crescimento: enquanto cooperativas de crédito mais antigas tendem a ser maiores na média, após o controle do tamanho e outros determinantes de crescimento, as instituições mais novas aparecem como sendo mais dinâmicas.

Continuando na linha de pesquisa sobre as cooperativas de crédito, Goddard et al. (2002) realizaram pesquisa sobre o crescimento das cooperativas de crédito nos EUA durante os anos 1990, utilizando informações financeiras publicadas pelas cooperativas de crédito e disponíveis na Administração Nacional das Cooperativas de Crédito - NCUA and Callahan and Associates, compreendendo uma amostra final de 7603 cooperativas de crédito, cobrindo um período de 10 anos (1990 a 1999) utilizando técnicas multivariadas cross sectional e estimação com painel de dados.

$\mathrm{Na}$ aplicação da técnica multivariada, Goddard et al. (2002) utilizaram o total do ativo como padrão para uma das medidas do tamanho, em virtude de que, anteriormente, pesquisadores o têm utilizado como a melhor medida para o tamanho da cooperativa de crédito. Eles citam como exemplo de outras pesquisas que utilizaram o total do ativo como padrão para medida do tamanho da empresa os seguintes trabalhos: Smith, 1986; Amburgey; Dacin, 1993; Barron et al., 1994.

Goddard et al. (2002) explicam que as cooperativas de crédito são cooperativas de instituições financeiras e podem ter alvará estadual ou federal. As que têm alvará estadual são 
supervisionadas pelos Escritórios de Regulamento Financeiro do Estado enquanto a federal é supervisionada pela NCUA. Eles afirmam que a maioria das cooperativas de crédito (cerca de $80 \%$ ) é definida por um vínculo profissional. Uma quantidade bem menor é definida por um vínculo associacional (14\%) ou residencial (6\%).

Goddard et al. (2002) explicam que a desregulamentação das cooperativas de crédito desde 1970, foi acompanhada da introdução de uma interpretação menos restritiva das obrigações comuns exigidas para a adesão dos cooperados, o que criou novas oportunidades de crescimento e de concentração no setor. Eles exemplificam que entre 1987 e 1999 o número de cooperativas de crédito baixou de 15.000 para 10.858 , enquanto o número de membros aumentou de 53 milhões para 76,6 milhões. O crescimento na concentração, também, refletese no aumento do tamanho médio das maiores 20 cooperativas de crédito, de US \$571 milhões em 1987 para US \$ 1.920 milhões em 1999.

O relaxamento das exigências restritivas para as obrigações comuns levou as cooperativas de crédito a uma competição com outras instituições financeiras, especialmente os bancos varejistas. A mudança regulamentar tem fornecido o principal estímulo para a consolidação e crescimento no movimento das cooperativas de créditos nos EUA. A literatura acadêmica é abundante de explicações de como certas instituições financeiras crescem e atingem grande escala (BERGER et al., 1999 apud Goddard et al., 2002). Porém, Gibrat (1931, apud Goddard et al., 2002) desenvolveu a hipótese que o crescimento de cada empresa em cada período é aleatório (em outras palavras, independentemente de características observáveis da empresa incluindo crescimento passado ou tamanho), que posteriormente ficou conhecido como a Lei de Efeito Proporcionado (LPE). De acordo com a LPE, o crescimento não está relacionado com o tamanho da empresa, assim grandes ou pequenas empresas têm a mesma probabilidade de alcançar uma taxa particular de crescimento em qualquer período.

Existe extensiva evidência empírica sobre a validade do LPE para as indústrias nos EUA e na Europa. Os resultados têm sido mistos. Goddard et al. (2002) afirmam que a maior parte dos primeiros estudos não encontrou qualquer relação ou encontrou uma relação positiva entre tamanho e crescimento, com base nos estudos de Hart e Prais (1956); Singh e Whittington (1968; 1975); Samuals e Chesher (1972). Estudos mais recentes têm encontrado que pequenas empresas crescem mais rapidamente e tendem a ter taxas de crescimento mais variáveis do que as grandes empresas. Goddard et al. (2002) citam como exemplos de estudos que 
encontraram um crescimento maior das pequenas empresas os seguintes: Wagner, 1992; Dunne; Hughes, 1994; Hart; Oulton, 1996; 1999. Barron (1992) e Barron et al. (1994) apud Goddard et al. (2002) analisaram as cooperativas de crédito com alvará estadual na cidade de Nova York entre 1914 e 1990 e rejeitaram a LPE, encontrando que grandes cooperativas de crédito crescem mais lentamente do que as pequenas. Quanto às instituições financeiras, somente alguns poucos estudos têm examinado a aplicabilidade da LPE para essas empresas.

Em virtude do aumento significativo da competição entre as cooperativas de crédito e os bancos pelos clientes depositantes, Hannan (2002) analisou o impacto da presença das cooperativas de crédito no mercado de depósito de consumidores, considerando como medida as taxas oferecidas pelos bancos e outras instituições de crédito para três diferentes tipos de contas de depósitos: contas para depósito em dinheiro; contas remuneradas e certificados de depósitos de 90 dias. Os dados foram obtidos de uma amostra composta de 250 instituições, por meio de survey conduzido pelo Bank Rate Monitor em 1998, abrangendo a nação como um todo, incorporando um número maior de instituições do que o utilizado em pesquisas anteriores. O tratamento dos dados foi realizado com regressões cross-sectional para explicar as diferenças nas taxas de depósito oferecidas pelos bancos e outras instituições financeiras. Os resultados produziram coeficientes positivos com significância estatística dessas medidas, ou seja, há uma diferença estatística relevante entre as taxas de depósitos oferecidas pelos bancos e pelas cooperativas de crédito. Encontrou, também, que existe uma dominância esmagadora de cooperativas de crédito profissionais sobre as cooperativas de crédito comunitárias seja utilizando como medida a proporção da parcela de depósitos ou a população de membros acima de 18 anos.

Hannan (2002) destaca, ainda, que evidências de interações competitivas entre bancos e cooperativas de créditos são reportadas por Emmons e Schmid (1999, 2000a, 2000b); Tokle e Tokle (2000); Feinberg (2001, 2002a, 2002b); Hannan e Prager (2001).

Na mesma linha dos estudos sobre as cooperativas, Tatom (2005) revisou a base histórica da isenção tributária do lucro das cooperativas de crédito, avaliou as conseqüências da isenção dos impostos federais e, também, quem ganha e quem perde com essa condição de isenção das cooperativas de crédito. 
As evidências diretas e indiretas colhidas para o estudo de Tatom (2005) mostram que os participantes das cooperativas de crédito recebem a redução do imposto como retornos extraordinários. Esses retornos extraordinários, entretanto, não aparecem como altos dividendos e, sim, como grandes lucros retidos acumulados no patrimônio líquido das cooperativas de crédito. O lucro extra dos cooperados, reinvestido na cooperativa de crédito, fornece novo capital que permite à cooperativa crescer mais rápido do que as outras instituições.

Tatom (2005) afirma que, no global, entretanto, o efeito dominante da isenção tributária é impulsionar o índice do patrimônio líquido (patrimônio líquido/total do ativo) das cooperativas de crédito. Em 2003, o índice do patrimônio líquido de todos os bancos comerciais era de $9,10 \%$, bem abaixo dos $10,7 \%$ das cooperativas de crédito, ou seja, 17,8\% maior do que o dos bancos. Isso está consistente com a análise da incidência tributária, que sugere que as cooperativas de crédito teriam um índice muito maior do que os bancos em virtude de que a isenção tributária afeta, principalmente, o tamanho do seu patrimônio líquido. Considerando os últimos dez anos, elas tiveram um índice 26,6\% maior do que o dos bancos. A isenção tributária e a constante erosão das restrições para os participantes das cooperativas de crédito permitiram que elas crescessem mais rapidamente do que os bancos, especialmente durante as últimas duas décadas.

Tatom (2005) esclarece que segundo as definições regulamentares, nos EUA é considerado um banco grande aquele que tiver ativos superiores a $\$ 1$ bilhão de dólares. No final do ano 2000, existiam apenas 43 cooperativas de crédito com ativos superiores a $\$ 1$ bilhão de dólares, enquanto o número de bancos com ativos superiores a esse limite era 397. No final do ano 2003, existiam 82 cooperativas de crédito com ativos superiores a \$ 1 bilhão de dólares contra 424 bancos com ativos desse tamanho. O número de grandes cooperativas de crédito cresceu $90,6 \%$ em apenas três anos enquanto o número de grandes bancos cresceu apenas $6,8 \%$.

Tatom (2005) afirma que a principal razão para a comparação das cooperativas de crédito com os bancos, porém, é que os bancos estão no mesmo mercado competitivo de depositantes e, também, embora em menor medida, dos mutuários das cooperativas de crédito. Devido à isenção de impostos concedida às cooperativas de crédito enquanto seus concorrentes bancos, instituições financeiras e de poupança - são tributados, o governo federal distorce a 
alocação de recursos e promove o aumento dos depósitos e recursos de crédito no setor das cooperativas de crédito, isentas de imposto, a expensas de todas as outras instituições financeiras.

Tatom (2005) ressalta que pesquisas sobre empresas que recebem apoio do governo e sobre cooperativas de crédito suportam a visão de que o principal efeito da isenção fiscal é um aumento no total do ativo e no índice do patrimônio líquido do setor das cooperativas de crédito.

O Quadro 5 apresenta uma síntese das pesquisas realizadas sobre incentivos fiscais no exterior, basicamente nos EUA, e consideradas neste estudo

Quadro 5 - Síntese das pesquisas realizadas sobre incentivos fiscais nos EUA e consideradas neste estudo

\begin{tabular}{|c|c|c|}
\hline Autor & Pesquisa nos EUA & Conclusão \\
\hline Guthmann (1951) & $\begin{array}{l}\text { Isenção tributária do imposto de } \\
\text { renda das cooperativas de } \\
\text { consumidores }\end{array}$ & $\begin{array}{l}\text { A isenção: } \\
\text { - acarreta aumento no valor do dividendo; } \\
\text { - encobre a verdadeira eficiência operacional da } \\
\text { cooperativa. }\end{array}$ \\
\hline Somers (1951) & Isenção de impostos em geral & $\begin{array}{l}\text { A isenção acarreta possível aumento do } \\
\text { dividendo. }\end{array}$ \\
\hline Harriss (1954) & Isenção de impostos em geral & $\begin{array}{l}\text { - os incentivos fiscais podem afetar a direção do } \\
\text { gasto privado; } \\
\text { - é muito difícil obter dados para avaliar os } \\
\text { montantes das isenções. }\end{array}$ \\
\hline Croteau (1956) & $\begin{array}{l}\text { Isenção nas grandes cooperativas } \\
\text { de crédito }\end{array}$ & $\begin{array}{l}\text { Não detectou diferenças significativas entre as } \\
\text { cooperativas de crédito de diferentes } \\
\text { dimensões. }\end{array}$ \\
\hline $\begin{array}{l}\text { Black e Dugger } \\
(1981)\end{array}$ & $\begin{array}{l}\text { Estrutura das cooperativas de } \\
\text { crédito }\end{array}$ & O capital das cooperativas de crédito declinou. \\
\hline $\begin{array}{l}\text { Gordon e } \\
\text { Slemrod (1983) }\end{array}$ & $\begin{array}{l}\text { Efeitos na eliminação dos } \\
\text { subsídios federais }\end{array}$ & $\begin{array}{l}\text { A tributação dos juros sobre os títulos } \\
\text { municipais prejudica os ricos e os pobres. }\end{array}$ \\
\hline $\begin{array}{l}\text { Barron et al. } \\
\text { (1994) }\end{array}$ & $\begin{array}{l}\text { Cooperativas de créditos antigas } \mathrm{x} \\
\text { novas }\end{array}$ & $\begin{array}{l}\text { - pequenas cooperativas de créditos tendem a } \\
\text { ter menor variabilidade no crescimento } \\
\text { comparativamente às grandes cooperativas; } \\
\text { - a idade é restritiva do crescimento: quanto } \\
\text { mais antiga é menos dinâmica. }\end{array}$ \\
\hline $\begin{array}{l}\text { Goddard et al. } \\
\text { (2002) }\end{array}$ & $\begin{array}{l}\text { Crescimento das cooperativas de } \\
\text { crédito }\end{array}$ & $\begin{array}{l}\text { - Houve concentração no setor, reduzindo o } \\
\text { número de cooperativas; } \\
\text { - houve aumento no tamanho médio das } \\
\text { cooperativas; } \\
\text { - pequenas cooperativas crescem mais } \\
\text { rapidamente do que as grandes. }\end{array}$ \\
\hline Hannan (2002) & Cooperativas de crédito $\mathrm{x}$ Bancos & $\begin{array}{l}\text { A taxa de depósito oferecida pelas cooperativas } \\
\text { de crédito é maior do que a oferecida pelos } \\
\text { bancos. }\end{array}$ \\
\hline
\end{tabular}


continuação

\begin{tabular}{|l|l|l|}
\hline Tatom (2005) & $\begin{array}{l}\text { Conseqüência da isenção tributária } \\
\text { do lucro das cooperativas de } \\
\text { créditos }\end{array}$ & - Cooperados recebem a isenção tributária \\
& como retornos extraordinários; \\
& - crescimento das cooperativas de crédito é \\
& maior do que o dos bancos; \\
& - há uma distorção na alocação dos recursos em \\
& favor das cooperativas de crédito em detrimento \\
& dos bancos; \\
& - há um aumento no total do ativo; \\
& - há um aumento no índice patrimônio \\
& líquido/ativo; \\
& - há um aumento do ROA; \\
& - há um aumento do ROE. \\
\hline
\end{tabular}

Em linhas gerais, pode-se observar que nos EUA existe uma linha de pesquisa que procede a uma comparação entre as Cooperativas de Créditos e Bancos Comerciais que concorrem no mesmo mercado consumidor, considerando que as Cooperativas de Créditos são isentas de impostos enquanto os bancos comerciais são tributados.

\subsection{Medidas de desempenho}

O contexto econômico pode ser abordado em termos macroeconômicos ou microeconômicos. A abordagem macroeconômica trata do sistema econômico como um todo e não das unidades econômicas individuais de que se compõe. O produto interno bruto (PIB), a taxa de desemprego, a taxa de juro (Sistema Especial de Liquidação e Custódia - SELIC), o consumo público constituem o centro de atenção. A macroeconomia preocupa-se com a natureza do crescimento econômico e das condições necessárias para a expansão da capacidade produtiva e da renda nacional ao longo do tempo. Por outro lado, a microeconomia trata da atividade econômica de unidades individuais, tais como consumidores, proprietários dos recursos e empresas. Trata do fluxo de bens e serviços das empresas para os consumidores, com a composição do fluxo, e com a avaliação ou formação de preços das partes componentes do fluxo. Preocupa-se, também, com o fluxo dos recursos produtivos (ou seus serviços) dos seus proprietários para as firmas comerciais, com sua avaliação e com a distribuição entre os empregos alternativos. (LEFTWICH, 1994, p. 9).

Assaf Neto (2002, p. 44-52) afirma que a empresa se situa como um agente facilitador de decisões econômicas, perseguindo objetivos tais como: lucratividade, rentabilidade e competitividade. 
Assim, neste estudo, em virtude de suas próprias características, é recomendada, portanto, a utilização da abordagem microeconômica, porque se tem interesse no efeito dos incentivos fiscais nas unidades econômicas denominadas empresas.

A análise de rentabilidade e lucratividade "é uma avaliação econômica do desempenho da empresa, dimensionando o retorno sobre os investimentos realizados e a lucratividade apresentada pelas vendas" (ASSAF NETO, 2002, p. 52). A análise financeira é utilizada numa variedade de contextos e a análise do desempenho presente e passado das empresas por meio de índices fornece o fundamento para fazer previsões do desempenho futuro. (PALEPU et al., 2004, p. 5-6).

Rossetti (2001) apud Cyrino e Dornas (2002, p.7) apurou que:

[...] na década passada, as 'margens' continuaram sendo medidas populares na análise de performance corporativa, entre empresas brasileiras de portes variados. Mas as análises por margens são limitadas para efeitos de pesquisa, pois não determinam o grau de eficiência com que a empresa utiliza seus ativos, ou seja, não evidenciam o esforço empreendido para gerar o lucro. $\mathrm{Na}$ busca por essa análise mais apurada, muitas das empresas que operam no mercado brasileiro mediram, na última década do século, o retorno sobre o patrimônio líquido ou ROE (Return on Equity), ou seja, um indicador que calcula o retorno do capital investido pelos proprietários da companhia (GITMAN, 1987), deixando transparecer, ainda, uma ascendente tendência de uso desse indicador, em exercícios fiscais vindouros.

As medidas contábeis têm sido utilizadas como proxy para o desempenho em inúmeros estudos de estratégia (RUMMELT, 1991; McGAHAN; PORTER, 1997; McGAHAN, 1999). Embora a métrica utilizada para aferir o desempenho seja um fator de discordância entre os autores de diferentes correntes. Barney (2007, p. 20) afirma que os indicadores contábeis de performance estão entre as quatro métricas de performance mais utilizadas nos estudos de estratégia.

Na visão de Palepu et al. (2004, p. 5-1) "O objetivo da análise financeira é avaliar o desempenho da empresa no contexto dos seus objetivos e estratégias estabelecidos."7 Eles explicam que "Existem duas principais ferramentas de análise financeira: análise de índices e análise de fluxo de caixa"» e, ainda, com relação à análise por índices, que "implica avaliar como os diversos itens das linhas das demonstrações financeiras das empresas relacionam-se

\footnotetext{
7 "The goal of financial analysis is to assess the performance of a firm in the context of its stated goals and strategy."

8 "There are two principal tools of financial analysis: ratio analysis and cash flow analysis."
} 
uns com os outros." ${ }^{99}$ Os autores afirmam, também, que o valor da empresa é determinado pela sua lucratividade e crescimento, os quais são influenciados por estratégias de produto, mercado e financeiras. As estratégias financeiras são implementadas por meio de políticas de financiamentos e políticas de dividendos.

Segundo Palepu et al. (2004, p. 5-4) o ponto de partida para uma análise sistemática do desempenho da empresa é o retorno do patrimônio líquido (do inglês Return on Equity ROE), definido como lucro líquido/patrimônio líquido. O ROE é um indicador global do desempenho da empresa, uma vez que fornece uma indicação de como os gestores estão empregando, e os respectivos retornos, os recursos investidos pelos acionistas da empresa.

Palepu et al. (2004, p. 5-5) explicam, ainda, que:

O ROE da empresa é afetado por dois fatores: da lucratividade do seu ativo e do tamanho do seu ativo comparativamente ao investimento dos acionistas. ${ }^{10}$

Com relação ao ROA (do inglês Return of Assets), Palepu et al. (2004, p. 5-6) orientam que:

ROA nos diz o quanto de lucro uma companhia é capaz de gerar para cada dólar de ativo investido. [...] A alavancagem financeira indica quantos dólares de ativo a empresa é capaz de acrescer para cada dólar investido pelos seus acionistas. ${ }^{11}$

Sobre a análise por meio de índices, Palepu et al. (2004, p. 5-17) explicam que:

Há uma série de índices que ajudam o analista nesta área. Para avaliar a combinação de dívida e patrimônio líquido na estrutura de capital de uma empresa, os seguintes índices são úteis:

1) índice da dívida total em relação ao patrimônio líquido = Passivo Total /Patrimônio Líquido;

2) índice da dívida com empréstimos onerosos em relação ao patrimônio líquido $=($ Empréstimos a Curto Prazo + Empréstimos a Longo Prazo) / Patrimônio Líquido;

[...]

4) índice da dívida com empréstimos onerosos em relação ao patrimônio líquido acrescido dos próprios empréstimos $=($ Empréstimos de Curto Prazo + Empréstimos de Longo Prazo $) /$ (Empréstimos de Curto Prazo + Empréstimos de Longo Prazo + Patrimônio Líquido); $(\ldots)^{12}$

\footnotetext{
9 "involves assessing how various line items in a firm's financial statements relate to one another."

10 "A company's ROE is affected by two factors: how profitably it employs its assets and how big the firm's asset base is relative to shareholder's investment."

11 "ROA tells us how much profit a company is able to generate for each dollar of assets invested. [...] Financial leverage indicates how many dollars of assets the firm is able to deploy for each dollar invested by its shareholders."

12 "There are a number of ratios which help the analyst in this area. To evaluate the mix of debt and equity in a firm's capital structure, the following ratios are useful: 1) Liabilities-to-equity ratio = Total liabilities/Shareholders' equity;2) Debt-to-equity ratio $=($ Short-term debt + Long-term debt $) /$ Shareholders'
} 
No Brasil, um dos efeitos dos incentivos fiscais sobre o desempenho econômico e financeiro das empresas foi descrito por Anuatti Neto et al. (2005, p. 157-162), que analisaram os efeitos da privatização sobre o desempenho das empresas privatizadas e detectaram um aumento na lucratividade e na eficiência operacional dessas empresas. No estudo, dentre outros indicadores, utilizaram para a mensuração do desempenho o retorno sobre o ativo (ROA) e o retorno do patrimônio líquido (ROE).

Os resultados apurados no estudo indicaram uma queda da razão entre imposto de renda devido e receita líquida (IL/RL). O imposto de renda devido (IR) foi apurado pela diferença entre os tributos calculados e as deduções permitidas. Dentre as categorias de deduções, Anuatti Neto et al. (2005, p. 157-162) apontam os incentivos fiscais que seriam uma das causas explicativas para a redução do indicador de pagamento de impostos e, conseqüentemente, da melhoria do desempenho das empresas privatizadas.

Outro efeito das isenções fiscais sobre o desempenho das empresas é descrito por Tatom (2005, p. 10-22), que pesquisou os efeitos das isenções fiscais nas cooperativas de crédito dos Estados Unidos da América (EUA). Ele afirma que os órgãos reguladores dos EUA avaliam o índice do capital próprio como um fator positivo na determinação do desempenho das cooperativas de crédito. Embora o índice do capital próprio não reflita somente a influência de fatores econômicos, como a isenção de impostos, em virtude da isenção, existem pressões regulamentares para manter o índice do capital próprio alto e, dessa forma, esse índice das cooperativas de crédito estaduais seria maior do que se esperava, caso fosse levado em consideração somente os efeitos fiscais.

Tatom (2005) afirma que a isenção fiscal aumenta a taxa de retorno sobre o ativo (ROA) e do patrimônio líquido (ROE). O autor concluiu, ainda, que, embora as despesas fiscais decorrentes das isenções fiscais das cooperativas de crédito sejam grandes e crescentes, as limitações dos dados comparáveis, especialmente taxas de juros e custo, não permitiram uma estimativa definitiva da incidência do imposto. Porém, o efeito global da isenção fiscal pode ser medido pelo aumento da taxa de retorno sobre ativos, antes dos impostos, que seria necessário para manter a taxa de retorno sobre ativos, após os impostos, inalterada. Com uma taxa de $33 \%$ de imposto e uma taxa média de retorno sobre ativos de $1 \%$, o ROA antes dos

equity; [...] 4) Deb-to-capital ratio $=($ Short-term debt + Long-term debt $)($ Short-term debt + Long-term debt + Shareholders' equity)" 
impostos, na ausência de isenção, deveria ser 1,50 pontos percentuais, ou seja, 50 pontos-base maior. Tatom (2005) afirma que esse é o tamanho do subsídio (por dólar de ativo) que se reverte para os beneficiários da atual isenção fiscal nas cooperativas de créditos dos EUA.

Mensurando o desempenho dos centros de investimento, Hansen e Mowen (2001, p. 320-321) afirmam que as três medidas financeiras de avaliação de desempenho para os centros de investimento são: o retorno sobre o investimento - ROI: o resultado residual - RI (Residual Income) e o valor econômico adicionado - EVA (Economic Value Added). Para Hansen e Mowen (2001, p. 321) o ROI é a medida mais comum de desempenho para um centro de investimento e pode ser definido pela razão entre o resultado operacional (lucro antes dos juros e dos impostos) e a média dos ativos operacionais (ativos adquiridos para gerar resultado operacional). Com relação ao resultado residual, Hansen e Mowen (2001, p. 325) explicam que ele decorre da diferença entre o resultado operacional e o retorno mínimo em unidades monetárias exigido sobre os ativos operacionais (taxa mínima de retorno x ativos operacionais). Relativamente ao EVA, Hansen e Mowen (2001, p. 326) orientam que é decorrente do resultado operacional após o imposto de renda menos o total do custo anual do capital. Se o EVA for positivo, a empresa está criando riqueza, caso contrário a empresa está destruindo riqueza.

Ferreira (2007, p. 333) afirma que o Balanced Scorecard (BSC) surgiu da iniciativa de Kaplan e Norton de criar um novo modelo de medição de desempenho e que ele contempla uma estrutura de indicadores estratégicos que considera a importância crescente dos valores intangíveis diante dos tradicionais valores físicos. O BSC complementa as medições baseadas apenas em indicadores financeiros, considerando quatro perspectivas: 1) financeiras; 2) do cliente; 3 ) dos processos internos; 4) de aprendizado e crescimento.

Atkinson et al. (2008, p. 94-96) afirmam que as medidas de desempenho são partes críticas do controle das operações e parte do processo de avaliação do desempenho é comparar o realizado com algum padrão ou nível-alvo de desempenho. Eles afirmam que a principal medida de desempenho da contabilidade gerencial é o custo e que para melhorar o desempenho dos custos, utilizando como base de análise o método denominado gestão por atividades ou gestão baseada em atividades, é necessário o exame da necessidade, eficiência e eficácia das atividades existentes e de quaisquer novas atividades. 
Para Assaf Neto (2006, p. 174-175), o sucesso de um empreendimento é medido por sua capacidade de adicionar riqueza a seus acionistas dentro de um horizonte indeterminado de tempo. Nesse sentido, o modelo de valor prioriza, essencialmente, o longo prazo e a capacidade da empresa de competir e ajustar-se ao mercado. Ele afirma que o principal indicador de agregação de riqueza é a criação de valor econômico e que para avaliar a capacidade de agregação de valor da empresa são desenvolvidos direcionadores de valor dos negócios, que pode ser entendido como qualquer variável que tenha influência sobre o valor da empresa. Assaf Neto (2006, p. 177) exemplifica os seguintes direcionadores de valor: fidelidade dos clientes, satisfação dos empregados, alternativas de financiamento, necessidades dos clientes, produtos com maior giro, rapidez no atendimento, valor da marca.

O Quadro 6 apresenta uma síntese das obras e pesquisas realizadas sobre medidas de desempenho consideradas neste estudo.

Quadro 6 - Síntese das obras e pesquisas realizadas sobre medidas de desempenho consideradas neste estudo

\begin{tabular}{|c|c|c|}
\hline Autor & Assunto & Conclusão \\
\hline $\begin{array}{l}\text { Gitman (1987); } \\
\text { Rossetti (2001); } \\
\text { Cyrino e Dornas } \\
\text { (2002) }\end{array}$ & $\begin{array}{l}\text { Análise de performance } \\
\text { corporativa }\end{array}$ & $\begin{array}{l}\text { Na década de } 1980 \text { muitas empresas brasileiras } \\
\text { utilizaram o ROE para análise do lucro. }\end{array}$ \\
\hline $\begin{array}{l}\text { Rummelt (1991); } \\
\text { McGahan e } \\
\text { Porter (1997); } \\
\text { McGahan (1999) }\end{array}$ & Desempenho corporativo & $\begin{array}{l}\text { As medidas contábeis têm sido utilizadas como } \\
\text { proxy para o desempenho. }\end{array}$ \\
\hline Leftwich (1994) & Contexto econômico & $\begin{array}{l}\text {-Macroeconomia: trata do sistema econômico } \\
\text { como um todo; } \\
\text {-Microeconomia: trata da atividade econômica de } \\
\text { unidades econômicas individuais (empresas). }\end{array}$ \\
\hline $\begin{array}{l}\text { Hansen e Mowen } \\
(2001)\end{array}$ & Avaliação de desempenho & $\begin{array}{l}\text { Indicam para medida de desempenho: ROI, RI e } \\
\text { EVA }\end{array}$ \\
\hline $\begin{array}{l}\text { Assaf Neto } \\
(2002)\end{array}$ & Análise de rentabilidade & $\begin{array}{l}\text { A análise de rentabilidade é uma avaliação } \\
\text { econômica do desempenho da empresa, } \\
\text { dimensionando o retorno sobre os investimentos. }\end{array}$ \\
\hline $\begin{array}{l}\text { Palepu et al. } \\
(2004)\end{array}$ & $\begin{array}{l}\text { Análise do desempenho da } \\
\text { empresa }\end{array}$ & $\begin{array}{l}\text {-O ponto de partida para uma análise do } \\
\text { desempenho da empresa é o ROE. } \\
\text {-Para avaliar a combinação de dívida e Pl na } \\
\text { estrutura de capital são úteis o LER, DER e DCR. }\end{array}$ \\
\hline $\begin{array}{l}\text { Anuatti-Neto } \text { et } \\
\text { al. }(2005)\end{array}$ & Mensuração de desempenho & $\begin{array}{l}\text { Dentre outros indicadores, utilizaram para a } \\
\text { mensuração do desempenho o ROA e o ROE. }\end{array}$ \\
\hline Tatom (2005) & Isenção fiscal & $\begin{array}{l}\text { A isenção fiscal aumenta a taxa do ROA e do } \\
\text { ROE. }\end{array}$ \\
\hline Ferreira (2007) & Medição de desempenho & $\begin{array}{l}\text { O BSC complementa as medições baseadas } \\
\text { apenas em indicadores financeiros. }\end{array}$ \\
\hline Narney (2007) & Indicadores de performance & $\begin{array}{l}\text { Os indicadores contábeis de performance estão } \\
\text { entre as quatro métricas mais utilizadas. }\end{array}$ \\
\hline $\begin{array}{l}\text { Atkinson et al. } \\
(2008)\end{array}$ & Medidas de desempenho & $\begin{array}{l}\text { A principal medida de desempenho da } \\
\text { contabilidade gerencial é o custo. }\end{array}$ \\
\hline
\end{tabular}




\subsection{Estrutura de capital}

Howell (1949) afirma que a discussão sobre o impacto da tributação federal do lucro sobre as finanças corporativas está dividida em duas partes: 1) o efeito desse imposto sobre as atividades de investimento das pessoas que podem ser potenciais compradoras de ações; 2) os efeitos que esse imposto tem sobre os tipos de ações que as empresas emitem.

Os impostos sobre a renda pessoal dos investidores têm um duplo impacto: por um lado, sobre a capacidade do contribuinte para economizar uma grande quantia de dinheiro e, por outro lado, sobre o que ele é induzido a fazer com os recursos que economizou.

A importância econômica dos impostos sobre a renda pessoal reside no fato de que eles influenciam tanto a quantidade de recursos disponíveis para investimento, como também a direção do investimento, isto é, onde os recursos serão aplicados.

A obtenção de um financiamento saudável para um plano financeiro é aquele em que o financiamento da dívida e os inerentes encargos fixos não comprometem a solvência da empresa. Durante vários anos dois fatores contribuíram para que as empresas alterassem sua estrutura de capital com uma pesada proporção de dívida: a) a disponibilidade de empréstimo a baixo custo e 2) o subsídio da dedução dos juros e custos vinculados da base de cálculo do imposto de renda.

Howell (1949) afirma que, em 1943, um grupo de funcionários da Securities Exchange Comission - SEC fez uma análise comparativa das demonstrações financeiras dos anos de 1937 e 1941, de 201 grandes empresas industriais, com relação a mudanças nas suas estruturas de capital. As empresas tinham em 1937 uma dívida de longo prazo no valor de $12 \%$ do total do capital investido e, em 1941, para o mesmo grupo de empresas, o índice foi de $14 \%$, apresentando um aumento de $16 \%$.

O relatório do pessoal da SEC concluiu que não era possível provar que a dedutibilidade dos juros para efeitos fiscais era a causa principal do aumento na proporção das dívidas nas estruturas de financiamento das empresas. No entanto, vários dados indicam que a política fiscal é um fator que contribuiu para o aumento do endividamento. Do ponto de vista dos 
emissores de valores mobiliários, a tendência seria a de emitir, preferencialmente, obrigações em vez de ações para obtenção de novos recursos. Entretanto, outros estudos, comparando o índice da dívida e o de capital próprio ao longo de várias décadas, não perceberam a evolução distinta do financiamento da dívida.

O Relatório Econômico Anual de 1949, do Presidente do Conselho de Assessores Econômicos, constatou que, em 1948, houve elevada percentagem de financiamento externo por parte das empresas, principalmente, em função do baixo custo da captação de empréstimos e da possibilidade de dedução dos juros dos empréstimos da base de cálculo do imposto de renda. (HOWELL, 1949).

O artigo sobre estrutura de capital de Modigliani e Miller (1958) é o pilar da teoria moderna de finanças, além de tratar-se de um artigo seminal no desenvolvimento e prática da teoria econômica. (STIGLITZ, 1988; PROCIANOY; SCHMITT; 1995; FORTE, 2007).

Em termos microeconômicos, a decisão da estrutura de capital passou de coadjuvante financeiro para elemento primordial de estratégia empresarial, com consequiências macroeconômicas fundamentais. (BERLE; MEANS; 1987 apud FORTE, 2007, p. 19-20). A fundamentação teórica da estrutura de capital parte do paradigma neoclássico do homo economicus, cujas decisões utilizam a lógica formal de maximização de resultados. (FORTE, 2007, p. 21).

De forma geral, as teorias sobre estrutura de capital podem ser resumidas no que ficou comumente denominado Trade-off, Pecking Order e o Equity Market ou Windows of Opportunity (Janela de Oportunidades). (POHLMANN, 2005; FORTE, 2007, p. 22).

Sinteticamente, a teoria do Trade-Off está baseada nas economias fiscais relacionadas ao uso de dívidas e aos custos de falência esperados, buscando minimizar o custo total da dívida. Nesse caso, ganham importância as variáveis que expressam a utilidade das dívidas para fins de economia fiscal, bem como variáveis que expressem a magnitude dos custos de dificuldades financeiras esperados, tais como: liquidez corrente, custos de falência esperados, volatilidade dos retornos operacionais e potencial de crescimento da empresa. (FORTE, 2007, p. 22). 
Outra das teorias importantes é a teoria do Pecking Order (ordem de escolha). Existiria dessa forma, segundo Myers e Majluf (1984), uma hierarquia na ordem de preferências em relação à escolha de obtenção de recursos externos e internos. Uma vez que os administradores da empresa são mais bem informados do que os investidores em relação às tendências dos negócios da empresa (relação de assimetria de informação), a escolha inicial recairia no uso de recursos internos. Nessa lógica, empresas que geram mais caixa operacional e sejam mais rentáveis operacionalmente tenderiam a ser menos endividadas. Os gestores prefeririam, portanto, utilizar, na ordem, recursos gerados internamente, captar recursos por meio de novas dívidas e, em último lugar, captar recursos por meio do lançamento de novas ações. Essa hierarquia de escolha se constitui na base da teoria do pecking order. A fundamentação teórica reside no fato de os recursos gerados internamente não apresentarem custos de transação. (FORTE, 2007, p. 23).

A terceira das alternativas de explicação é a das janelas de oportunidade (Windows of opportunity, também chamada de Equity Market Timing). De acordo com Huang e Ritter (2005, apud FORTE, 2007, p. 23-24), essa alternativa de explicação propõe que executivos das corporações emitam ações baseando-se na relação custos de emissão de ações e dívida, sendo a estrutura de capital a resultante da somatória das decisões periódicas. Em outras palavras, empresas optariam por utilizar capital próprio quando seu custo relativo (custos de emissão de ações) for baixo em relação à captação de dívida, o que ocorre em momentos de alta valorização das ações nas Bolsas de Valores.

Sobre a estrutura de capital, Titman e Wessels (1988, p. 1) afirmam que:

[...] inúmeras teorias têm sido propostas para explicar a variação nos índices de endividamento das empresas. As teorias sugerem que as empresas selecionam sua estrutura de capital de acordo com os atributos que determinam os vários custos e benefícios associados à decisão de financiamento. ${ }^{13}$

Titman e Wessels (1988, p. 2) apresentam, ainda:

[...] uma breve discussão dos atributos que diferentes teorias sugerem que possam afetar a escolha da estrutura de capital da empresa. Esses atributos são: estrutura do ativo, proteção para

13 "[...] a number of theories have been proposed to explain the variation in debt ratios across firms. The theories suggest that firms select capital structures depending on attributes that determine the various costs and benefits associated with debt and equity financing." 
taxas não vinculadas a dívidas, crescimento, singularidade, classificação industrial, tamanho, volatilidade de lucros e rentabilidade. ${ }^{14}$

Forte (2007) afirma que as teorias que dão suporte aos atributos escolhidos na determinação da estrutura de capital defendem a idéia de que:

1) em relação ao atributo estrutura dos ativos, teóricos afirmam que empresas com maior volume de ativos tangíveis seriam mais endividadas, já que a oferta de garantias reduz o custo do endividamento. Assim, quanto maior o valor dos ativos tangíveis detidos pela empresa, maior sua propensão ao endividamento. Pela mesma razão, quanto maior o valor de seus ativos intangíveis, menor deveria ser sua propensão ao endividamento;

2) quanto ao atributo outros benefícios fiscais que não os gerados pelo endividamento, empresas que contam com benefícios fiscais advindos da depreciação e com subsídios deveriam ter menos incentivo ao endividamento, pois tirariam menos proveito do incentivo fiscal gerado pelo pagamento de juros;

3) quanto ao atributo crescimento da empresa, empresas cujas ações não são pulverizadas têm uma tendência a investirem de forma sub-ótima a fim de expropriar a riqueza dos credores. Essa tendência é ainda maior em empresas com potencial de crescimento, que têm maior flexibilidade em suas escolhas de investimento. Para essas empresas, o custo do endividamento deveria ser maior, desestimulando o endividamento;

4) quanto ao atributo singularidade, empresas que, ao serem liquidadas, geram um alto custo para a sociedade (empresas com alto grau de singularidade) deveriam ser mais conservadoras, evitando o risco de falência e, conseqüentemente, o endividamento;

5) quanto ao atributo classificação na indústria, empresas do setor de bens de capital demandam equipamentos e serviços mais especializados, remetendo ao caráter singular da atividade e, conseqüientemente, ao menor endividamento;

6) quanto ao atributo tamanho, empresas menores apuram custos de endividamento inferiores ao custo de chamada de capital, especialmente no curto prazo, conseqüentemente, empresas menores deveriam ser mais propensas ao endividamento de curto prazo;

7) quanto ao atributo volatilidade, empresas que apresentam menor volatilidade em seus resultados deveriam ter um incentivo maior ao endividamento, por obterem menores taxas;

\footnotetext{
14 "[...] ] brief discussion of the attributes that different theories of capital structure suggest may affect the firm's debt-equity choice. These attributes are denoted asset structure, non-debt tax shields, growth, uniqueness, industry classification, size, earnings volatility, and profitability.
} 
8) quanto ao atributo lucratividade, empresas deveriam obter financiamento pelos instrumentos relacionados na seguinte ordem: lucros retidos, endividamento, emissões. Assim, empresas com alta lucratividade deveriam ser menos endividadas.

Diferentes estudos sugerem que diferentes atributos possam afetar a escolha da estrutura de capital de uma empresa. Basicamente, esses atributos são: estrutura do ativo, proteção para taxas não vinculadas a dívidas, crescimento, classificação industrial, tamanho, volatilidade de lucros e rentabilidade. $\mathrm{O}$ estudo desses atributos que afetam a escolha da estrutura de capital da empresa desenvolvido por Titman e Wessels (1988) teve como resultados os seguintes:

1) empresas que trabalham com produtos especializados ou únicos (atributo singularidade) apresentaram menor propensão ao endividamento tanto de longo quanto de curto prazo (correlação negativa entre o fator e o grau de endividamento);

2) empresas menores (atributo tamanho) apresentaram maior propensão ao endividamento de curto prazo do que empresas maiores (correlação negativa entre o fator e o grau de endividamento de curto prazo);

3) o modelo encontrou evidências de que empresas mais lucrativas (atributo lucratividade) apresentam um percentual de endividamento, tanto de curto quanto de longo prazo, menor.

4) o modelo não encontrou evidências de que a estrutura de capital de uma empresa estivesse relacionada à sua expectativa de crescimento, a outros benefícios fiscais que não os gerados pelo endividamento, à volatilidade de seus lucros ou à estrutura de seus ativos.

Utilizando o modelo proposto por Titman e Wessels (1988), Perobelli e Famá (2002) adaptaram-no para o caso brasileiro com dois objetivos principais, verificar: 1) os fatores indutores de endividamento para as empresas brasileiras e 2) a convergência entre os resultados (cargas fatoriais) do Modelo de Medida proposto pelos autores e estimado com restrições e os resultados apurados pela Análise Fatorial estimada sem restrições.

Para tanto, selecionaram, por meio do banco de dados da Economática, 172 companhias abertas brasileiras cujos dados estavam disponíveis. Desse total, 7 empresas foram retiradas da amostra por terem apresentado patrimônio líquido médio negativo no período analisado, em virtude de que distorcia a análise, já que várias medidas por eles utilizadas foram 
expressas como percentual desse valor. Dessa forma, a amostra final englobou 165 companhias abertas. As variáveis do modelo foram observadas no período de 1995 a 2000.

Com relação à variável "Outros benefícios fiscais que não os gerados pelo endividamento", Perobelli e Famá (2002) não conseguiram utilizar o indicador subsídios/ativo total (ITC/TA) para o caso brasileiro por não estar disponível no banco de dados da Economática.

Com relação ao escudo fiscal da dívida (tax shields) ou vantagem fiscal decorrente da dedução do imposto de renda dos juros da dívida, Kemsley e Nissim (2002) utilizaram regressões cross-sectional, em uma amostra de 2.964 empresas do banco de dados da Compustat, cobrindo o período de 1963 a 1993, resultando numa amostra com 42.505 observações empresa-ano, para estimar o valor do escudo fiscal da dívida, líquido da desvantagem fiscal pessoal da dívida. Reconhecendo que a dívida está correlacionada com o valor das operações ao longo das dimensões não tributárias, estimaram o inverso das regressões (rentabilidade futura $=$ valor da empresa + dívida) para atenuar os efeitos dessa correlação.

Kemsley e Nissim (2002) utilizaram como variáveis: valor de mercado da empresa (valor de mercado das ações ordinárias, mais o valor contábil das dívidas e ações preferenciais); valor da dívida (débitos de financiamento); lucro operacional futuro (lucro operacional médio durante os cinco anos subseqüentes); ativo operacional líquido (ativo total menos débitos de funcionamento) e passivo operacional (débitos de funcionamento). Dessa forma, encontraram que, na média, as empresas financiam $27 \%$ de seus ativos com dívidas (débitos de financiamento) e $24 \%$ com passivos operacionais (débitos de funcionamento) e que o valor de mercado da empresa (após remover os débitos de funcionamento) é 118\% do valor contábil dos ativos totais.

Finalmente, Kemsley e Nissim (2002) encontraram que o valor da empresa é uma função forte e positiva da dívida. O valor estimado para o escudo fiscal da dívida é de cerca de $40 \%$ do saldo da dívida, líquido da desvantagem fiscal pessoal da dívida, o que sugere que, na média, o escudo fiscal da dívida aumenta o valor total da empresa (incluindo os débitos de funcionamento) em, aproximadamente, 10\%. De forma similar, Graham (2000) calculou que a média dos benefícios fiscais corporativos da dívida são de, aproximadamente, $10 \%$ do valor total da firma. 
Butters (1949) afirma que a tributação do lucro tem certos efeitos diretos que são, conscientemente, considerados quando decisões de investimentos são tomadas. Segundo ele, a tributação do lucro afeta a escolha entre financiamento interno e externo de três formas, influenciando:

1) o nível de lucratividade do negócio;

2) as decisões dos gerentes para reter o lucro ou distribuí-lo;

3) as condições na qual o capital externo pode ser obtido.

À medida que os impostos corporativos não são deslocados, reduzirão os lucros da empresa. Eles tendem a restringir os gastos com investimentos ou, alternativamente, estimular um aumento da dependência de financiamento externo. A medida, na qual os impostos corporativos tenderão a um ou outro desses efeitos, dependerá de circunstâncias específicas.

Butters (1949) afirma que um efeito direto que o imposto pode ter sobre a distribuição de dividendos decorre da relação entre a taxa de imposto da empresa e a estrutura altamente progressiva da taxa de imposto de renda pessoal. Um incentivo é criado pelas empresas controladas por acionistas ricos, na retenção de dividendos, que lhes permita evitar elevados impostos sobre os seus rendimentos pessoais.

Os impostos corporativos prejudicam a captação de capital externo porque eles reduzem os potenciais ganhos da empresa. Em geral, as elevadas taxas de impostos sobre o rendimento pessoal desencoraja os investidores que investem em ações para fins de obtenção de dividendos. O rendimento líquido, após os impostos, dessas ações deve ser bastante elevado em comparação, por exemplo, com investimentos isentos de impostos, para compensar os investidores pelo risco envolvido.

Assim, os elevados impostos corporativos são relativamente mais repressivos em empresas com rápido crescimento do que em empresas grandes e estáveis. Os elevados impostos sobre os rendimentos pessoais são relativamente mais severos em seus efeitos sobre empresas estabelecidas que oferecem menos oportunidade para aumento de capital.

Modigliani e Miller (1958) argumentam que sob determinadas condições, entre elas a ausência de impostos, a estrutura de capital e a política de dividendos são irrelevantes para o 
valor das empresas. Diante das críticas surgidas pelo fato de os impostos não terem sido levados em consideração, Modigliani e Miller (1963) publicaram um novo trabalho incluindo os tributos e reconheceram haver um ganho devido à alavancagem financeira. Basicamente, o benefício fiscal da dívida seria obtido pelo fato de que a sua remuneração (juros que a empresa paga) é descontada do lucro tributável na forma de despesa. Modigliani e Miller (1958) demonstraram que o ganho devido à alavancagem é dado por:

$$
\mathrm{G}=\mathrm{VI}-\mathrm{VU}=\mathrm{Tc} * \mathrm{~B}
$$

em que:

$\mathrm{G}=$ Ganho com a alavancagem ou benefício fiscal da dívida;

VI = Valor da empresa alavancada;

$\mathrm{Vu}=$ Valor da empresa não-alavancada;

Tc = Alíquota de imposto de renda da empresa;

$\mathrm{B}=$ Valor de mercado da dívida da empresa $=\mathrm{D} / \mathrm{i}$;

$\mathrm{D}=$ Valor de face da dívida;

$\mathrm{i}$ = Taxa de desconto da dívida para papéis de risco equivalente.

Observe-se que quanto menor a taxa do imposto de renda efetiva, menor o incentivo para o endividamento. No caso da empresa isenta do imposto de renda, o ganho é nulo e, portanto, não existe nenhum incentivo ao endividamento motivado pela tributação.

Aperfeiçoando o modelo original, Miller (1977) incluiu, além dos impostos sobre as empresas, os impostos pessoais incidentes sobre as receitas dos investidores, sejam eles credores ou acionistas.

$$
\mathrm{G}=[1-(1-\mathrm{Tc})(1-\mathrm{Ts}) /(1-\mathrm{Tb})] * \mathrm{~B}
$$

em que:

$\mathrm{G}=$ Ganho com a alavancagem ou benefício fiscal da dívida;

Tc = Alíquota de imposto de renda da empresa;

Ts = alíquota incidente sobre dividendos e ganhos de capital;

$\mathrm{Tb}=$ alíquota incidente sobre os juros auferidos pelos credores;

$\mathrm{B}=$ Valor de mercado da dívida da empresa $=\mathrm{D} / \mathrm{i}$; 
$\mathrm{D}$ = Valor de face da dívida;

$\mathrm{i}=$ Taxa de desconto da dívida para papéis de risco equivalente.

Atualmente, no Brasil, a distribuição de dividendos não é afetada pelo imposto de renda em virtude de que o lucro a ser distribuído, se for o caso, já foi tributado. Assim, observe-se que a fórmula modificada, também, não oferece nenhum incentivo ao endividamento, uma vez que conduz a um ganho nulo ao tomador do empréstimo.

Procianoy e Schmitt (1995) explicam que a fórmula de Miller (1977) sugere a existência de uma taxa de juros de equilíbrio no mercado, estabelecida pela oferta de recursos por parte dos investidores na forma de dívida e a demanda desses mesmos recursos pelas empresas. Dessa forma, acima dessa taxa tornam-se desinteressantes os benefícios fiscais da dívida e abaixo dela o endividamento seria estimulado. Com isso, existiria uma estrutura agregada ótima de capital, isto é, o montante total de dívida e de capital próprio das empresas, para a economia com um todo. Além disso, segundo Miller os ganhos da alavancagem não seriam tão grandes quanto originalmente se pensava, uma vez que seriam, em parte, contrabalanceados com os impostos incidentes em nível de pessoa física dos investidores.

A partir disso, vários autores desenvolveram modelos de estrutura de capital como um compromisso (trade-off) entre o valor dos benefícios fiscais proporcionados pela dívida versus os custos de inadimplência (CI). Em oposição ao modelo dinâmico, conhecido como Pecking Order, de Myers e Majluf (1984), Myers (1984) denominou esse novo modelo de estático, conhecido como Trade-off. No modelo estático, as empresas estabelecem uma meta de endividamento expressa pela razão entre sua dívida e seus ativos totais (target debt-tovalue ratio) e se ajustam, gradualmente, a esse objetivo. Em contrapartida, no modelo Pecking Order, as empresas têm uma ordem de preferência por fontes de financiamentos, iniciando com recursos gerados internamente (lucros) que, uma vez esgotados, são complementados pela emissão de dívida nova (empréstimos) e, como última fonte de financiamento, a empresa lança novas ações. DeAngelo e Masulis (1980) estenderam o trabalho de Miller (1977) analisando o efeito de outros benefícios fiscais (denominados substitutos pelos autores), tais como: depreciação, incentivos e créditos fiscais, estoques de prejuízos fiscais a compensar e introduziram no modelo a possibilidade de as empresas e os investidores terem alíquotas efetivas de impostos diferenciadas. Uma implicação importante 
do trabalho de DeAngelo e Masulis (1980) é a existência de uma estrutura ótima determinada, endogenamente, para cada empresa, de acordo com suas condições particulares.

Procianoy e Schmitt (1995) explicam que foram obtidos resultados empíricos expressivos com o uso de novas metodologias de teste tomando como variável independente não a alíquota máxima do imposto de renda prevista na legislação, mas, sim, o valor marginal dessa alíquota, além de outras variáveis que se consideram tradicionalmente como influenciadoras na decisão de endividamento das empresas. Esses resultados empíricos respondem em boa parte à argumentação de Miller (1977) segundo a qual, embora a legislação tenha variado ao longo do tempo, o endividamento das empresas não a acompanhou proporcionalmente, pois, na verdade, a taxa marginal deve ser calculada para cada empresa, não tendo muito sentido o seu cálculo como média para a economia como um todo. Esses estudos mostram que os gestores e os investidores reagem às transformações tributárias buscando minimizar o pagamento de impostos e maximizar os ganhos, sendo praticamente unânime a crença de que os impostos devem ser importantes na decisão financeira.

Considerando a relevância do aspecto tributário, Pohlmann (2005) pesquisou a influência da tributação na decisão da estrutura de capital. O objetivo do estudo foi contribuir com a evolução da teoria que busca explicar a estrutura de capital das empresas e sua relação com o nível de tributação a que elas estão sujeitas, segundo a realidade brasileira. De forma geral, os achados da pesquisa confirmaram os principais fatores reconhecidos pela literatura como determinantes na estrutura de capital: ao lado da tributação, foram significativos, nos testes, a lucratividade e a estrutura de ativos. O fator tributação apareceu com grande destaque na explicação dos níveis de endividamento das empresas no Brasil.

Pohlmann (2005, p. 230-231) adverte ser conveniente um maior nível de evidenciação dos ajustes efetuados no lucro contábil para apuração do lucro tributável, de modo a tornar mais claro, por exemplo, o quanto a empresa usufrui de benefícios fiscais que reduzem o seu lucro tributável. Ele conclui em seu estudo que o nível de tributação da empresa afeta sua decisão quanto à estrutura de capital e a relação se dá no mesmo sentido, ou seja, quanto maior a incidência tributária, maior será o endividamento.

É importante esclarecer que o lucro tributável (ou lucro fiscal) é apurado a partir do lucro contábil. Uma vez apurado o lucro contábil (antes do cálculo do imposto de renda e da 
contribuição social sobre o lucro) a ele são adicionadas e subtraídas despesas não dedutíveis e receitas não tributáveis, segundo a Receita Federal do Brasil (RFB), e feita a compensação de prejuízos fiscais acumulados de exercícios anteriores, se for o caso, apurando-se, assim, o lucro tributável. Sobre esse lucro tributável é calculado o imposto de renda devido pela empresa.

Ressalte-se que o valor dos incentivos fiscais usufruídos pela empresa não estão refletidos no lucro líquido por ela apurado em virtude da forma de contabilização preconizada pela legislação brasileira. Assim, a utilização do lucro líquido contábil para avaliação do desempenho da empresa pode distorcer o seu real desempenho apresentado no período.

A hipótese subjacente a praticamente todos os modelos de estrutura de capital é que a taxa marginal elevada de impostos incentiva o uso de dívida como instrumento financeiro. Essa hipótese é atual e amplamente tão aceita que o imposto de renda americano (Internal Revenue Service - IRS) se reserva o direito de limitar a dedução de impostos, via pagamento de juros, quando entender que o endividamento da empresa (debt to equity ratio) for excessivo, principalmente se esse endividamento for devido a partes relacionadas, sejam elas empresas controladoras, controladas ou coligadas. Observe-se que a Taxa Marginal de Imposto (TMI), que, em última análise, reflete o imposto incidente sobre as receitas adicionais da empresa, diminui com a existência de outros itens que reduzem o imposto a pagar das empresas, tais como estoque de prejuízos fiscais, amortização de Pesquisa e Desenvolvimento - P\&D, investimentos em propaganda e marketing em geral, depreciação, outros incentivos fiscais (Programa de Alimentação do Trabalhador - PAT; Sudene, Programas de Desenvolvimento Regionais, Sudam).

O Quadro 7 apresenta uma síntese das pesquisas realizadas sobre estrutura de capital consideradas neste estudo. 
Quadro 7 - Síntese das pesquisas realizadas sobre estrutura de capital consideradas neste estudo

\begin{tabular}{|c|c|c|}
\hline Autor & Pesquisa & Conclusão \\
\hline Butters (1949) & $\begin{array}{l}\text { Tributação do lucro e } \\
\text { financiamento. }\end{array}$ & $\begin{array}{l}\text { Os impostos corporativos prejudicam a } \\
\text { captação de capital externo porque reduzem } \\
\text { os potenciais ganhos da empresa. }\end{array}$ \\
\hline Howell (1949) & $\begin{array}{l}\text { Impacto da tributação federal do } \\
\text { lucro nas finanças corporativas. }\end{array}$ & $\begin{array}{l}\text { Em } 1948 \text { as empresas endividaram-se em } \\
\text { virtude do baixo custo da captação de } \\
\text { empréstimos e devido à dedução dos juros da } \\
\text { base de cálculo do imposto de renda. }\end{array}$ \\
\hline $\begin{array}{l}\text { Modigliani e } \\
\text { Miller (1958) }\end{array}$ & Estrutura de capital. & $\begin{array}{l}\text { Reconheceram haver um ganho no } \\
\text { endividamento devido à alavancagem } \\
\text { financeira. }\end{array}$ \\
\hline $\begin{array}{l}\text { DeAngelo e } \\
\text { Masulis (1980) }\end{array}$ & $\begin{array}{l}\text { Analisaram o efeito de outros } \\
\text { benefícios fiscais sobre a estrutura } \\
\text { de capital. }\end{array}$ & $\begin{array}{l}\text { Existe uma estrutura ótima determinada } \\
\text { endogenamente para cada empresa. }\end{array}$ \\
\hline Myers (1984) & Teoria do Trade-off. & $\begin{array}{l}\text { Denominou o modelo de estrutura de capital } \\
\text { conhecido como Trade-off de modelo } \\
\text { estático. }\end{array}$ \\
\hline $\begin{array}{l}\text { Myers e Majluf } \\
(1984)\end{array}$ & Teoria do Pecking Order. & Modelo dinâmico de estrutura de capital. \\
\hline $\begin{array}{l}\text { Berle e Means } \\
(1987)\end{array}$ & Estrutura de capital. & $\begin{array}{l}\text { A decisão da estrutura de capital passou a ser } \\
\text { elemento primordial de estratégia } \\
\text { empresarial. }\end{array}$ \\
\hline $\begin{array}{l}\text { Titman e Wessels } \\
\text { (1988) }\end{array}$ & Teorias sobre estrutura de capital. & $\begin{array}{l}\text {-As teorias sugerem que as empresas } \\
\text { selecionam sua estrutura de capital } \\
\text { considerando a relação custo/benefício. } \\
\text {-Diferentes atributos afetam a escolha da } \\
\text { estrutura de capital: estrutura do ativo, } \\
\text { crescimento, classificação industrial, } \\
\text { tamanho, volatilidade de lucros e } \\
\text { rentabilidade. }\end{array}$ \\
\hline $\begin{array}{l}\text { Procianoy e } \\
\text { Schimitt (1995) }\end{array}$ & Endividamento. & $\begin{array}{l}\text {-Explicam que existe uma taxa de juros de } \\
\text { equilíbrio no mercado. } \\
\text {-Os gestores e os investidores reagem às } \\
\text { alterações tributárias buscando minimizar } \\
\text { impostos e maximizar ganhos. }\end{array}$ \\
\hline $\begin{array}{l}\text { Stiglitz (1988); } \\
\text { Procianoy e } \\
\text { Schimitt (1995) }\end{array}$ & Estrutura de capital. & $\begin{array}{l}\text { O artigo de Modigliani e Miller (1958) é o } \\
\text { pilar da teoria moderna de finanças. }\end{array}$ \\
\hline $\begin{array}{l}\text { Kemsley e } \\
\text { Nissim (2002) }\end{array}$ & $\begin{array}{l}\text { Estudo do valor do escudo fiscal da } \\
\text { dívida. }\end{array}$ & $\begin{array}{l}\text {-Na média as empresas financiam } 27 \% \text { de } \\
\text { seus ativos com dívidas. } \\
\text {-O valor estimado para o escudo da dívida } \\
\text { fiscal é de cerca de } 40 \% \text { do saldo da dívida. }\end{array}$ \\
\hline $\begin{array}{l}\text { Perobelli e Fama } \\
(2002)\end{array}$ & $\begin{array}{l}\text { Aplicação do modelo de Titman e } \\
\text { Wessels. }\end{array}$ & $\begin{array}{l}\text { Utilizando o modelo para o caso brasileiro, } \\
\text { com relação à variável "Outros Benefícios } \\
\text { Fiscais" não conseguiram utilizar o indicador } \\
\text { subsídios/ativo total, por não estar disponível } \\
\text { no banco de dados da Economática. }\end{array}$ \\
\hline Pohlmann (2005) & Tributação e estrutura de capital & $\begin{array}{l}\text { A tributação tem destaque na explicação dos } \\
\text { níveis de endividamento das empresas no } \\
\text { Brasil; }\end{array}$ \\
\hline
\end{tabular}




\section{PROCEDIMENTOS METODOLÓGICOS}

\subsection{Desenho da pesquisa e organização do trabalho}

As pesquisas originam-se nas idéias que constituem a primeira aproximação da realidade que se pretende pesquisar. Existem várias fontes que podem produzem idéias de pesquisas, tais como: experiências individuais, materiais escritos, materiais audiovisuais, conversas pessoais, observação de fatos e outras. A maioria das idéias iniciais são vagas e requerem maior análise para se transformarem em projetos mais estruturados. (SAMPIERI et al., 2006, p. 24).

Em sintonia com os discursos da metodologia científica, o tema de estudo deste trabalho, incentivo fiscal, surgiu depois de um longo processo de discussão e aflorou em uma das conversas pessoais que ocorriam nas reuniões periódicas de orientação. Ao longo do processo de pesquisa e discussão, o tema foi tomando uma configuração diferente até chegar ao formato final estruturado neste trabalho. Ressalte-se que a idéia inicial, naturalmente, tinha uma conformação específica e, somente após diversos meses de discussão e pesquisa, o tema tomou sua forma final.

De início, buscaram-se elementos de apoio ao estudo na teoria dos incentivos fiscais buscando-se identificar suas relações com outros fenômenos econômicos. Dessa forma, o desenvolvimento do estudo deu-se no âmbito da pesquisa bibliográfica, pesquisa documental e, por último, pesquisa de campo. Na pesquisa bibliográfica encontrou-se a base de sustentação para o relacionamento entre os incentivos fiscais, a estrutura de capital e a rentabilidade das empresas. Ainda, com base na teoria, identificaram-se os indicadores da estrutura de capital e da rentabilidade utilizados para a medição dos efeitos dos referidos incentivos. Na pesquisa documental buscaram-se, na Lei das Sociedades Anônimas e nas normas da Comissão de Valores Mobiliários e do Conselho Federal de Contabilidade, no âmbito nacional, e nas normas do International Accounting Standards Board - IASB e do Financial Accounting StandardS Board - FASB, no âmbito internacional, as diretrizes do processo contábil, ou seja, as orientações para o reconhecimento, mensuração e evidenciação dos fenômenos contábeis, especificamente, quanto aos incentivos fiscais. Por último, com base nos indicadores liabilities equity ratio - LER, debt equity ratio - DER e debt capital ratio - DCR, relativos à estrutura de capital, e return of assets - ROA e return of equity - 
ROE, relativos à rentabilidade, realizou-se o tratamento estatístico dos dados, a análise dos resultados e a conclusão do trabalho.

A síntese do desenvolvimento da pesquisa, desde a formulação do tema até as conclusões do estudo, está apresentada no desenho da pesquisa consubstanciada na Figura 16 e a organização do trabalho está estruturada na Figura 17.

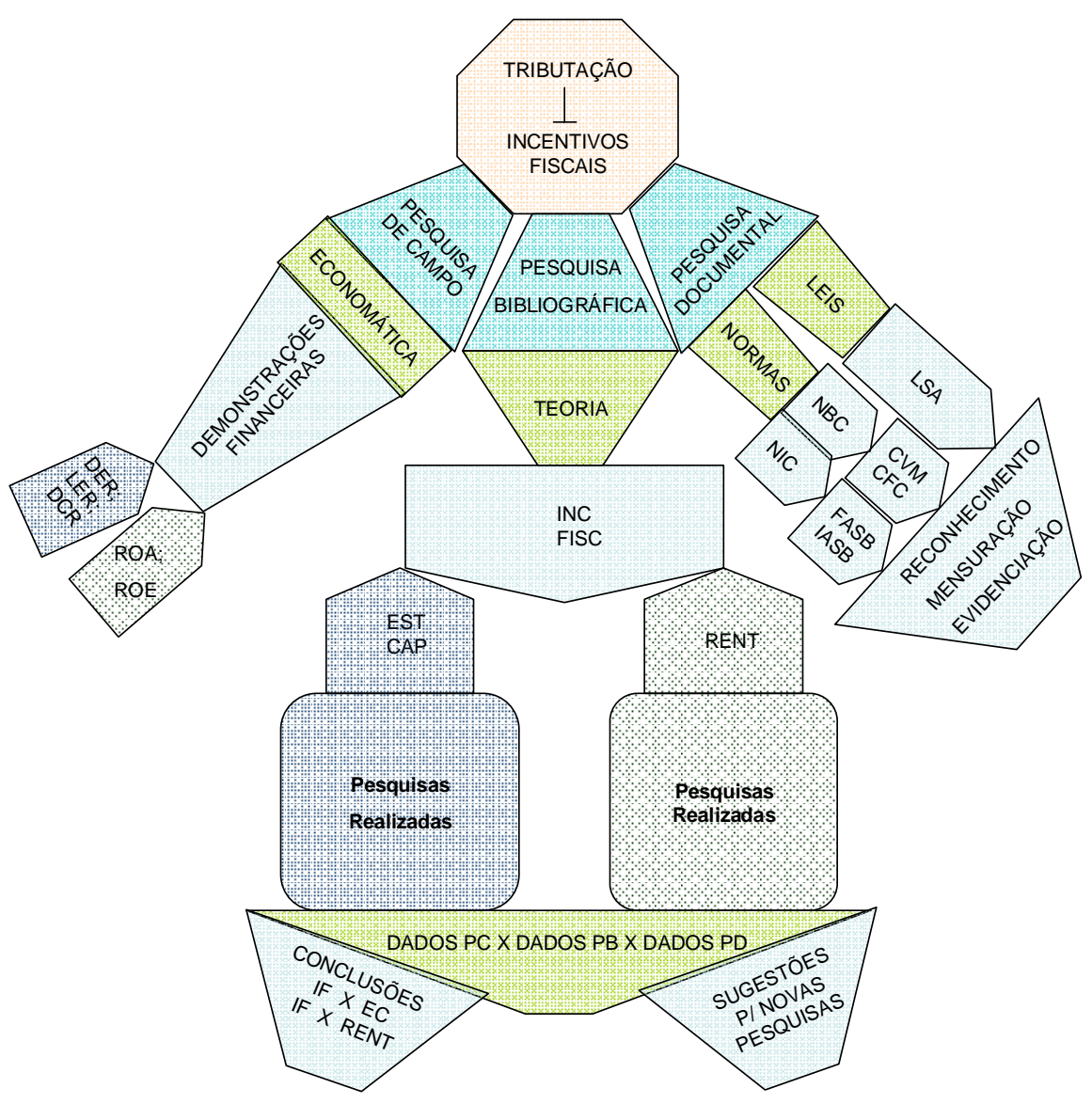

Figura 16 - Desenho da pesquisa 


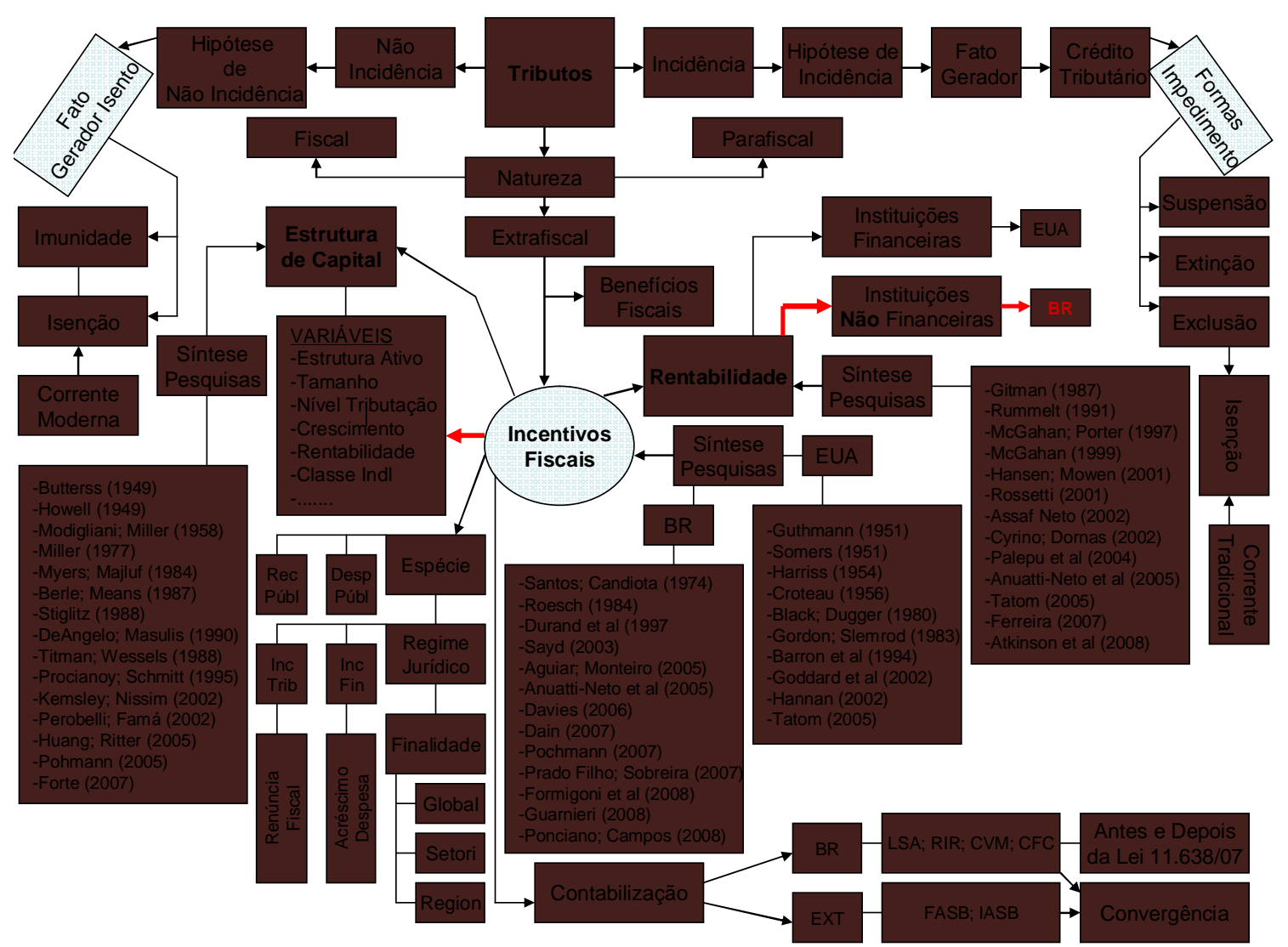

Figura 17 - Organização do trabalho

\subsection{Tipo de pesquisa}

Cervo e Bervian (2002, p. 65) afirmam que existem inúmeros tipos de pesquisa e que cada tipo possui, além do núcleo comum de procedimentos, suas peculiaridades próprias. Para Malhotra (2001), as pesquisas na área das ciências sociais podem ser classificadas em Exploratórias, Descritivas e Causais. Para Malhotra (2001), uma pesquisa descritiva pode ainda ser dividida em Transversal (um corte no tempo) e Longitudinal (ao longo do tempo).

A pesquisa descritiva observa, registra, analisa e correlaciona fatos ou fenômenos (variáveis) sem manipulá-los. Procura descobrir a frequiência com que um fenômeno ocorre, sua relação e conexão com outros, sua natureza e características, colhendo dados ou fatos da própria realidade. A coleta de dados aparece como uma das tarefas características da pesquisa descritiva. (CERVO; BERVIAN, 2002, p. 66-68). 
Em vista do exposto, o presente estudo pode ser classificado como descritivo-longitudinal e transversal. Ele é descritivo-longitudinal, pois se realizou a descrição (e análise de correlação) da estrutura de capital e retorno do ativo e patrimônio líquido de um mesmo conjunto de empresas ao longo de 13 anos. O estudo pode, também, ser classificado como descritivotransversal, pois se considerou o valor médio dos indicadores de estrutura e retorno dos 13 períodos, os quais foram utilizados em uma análise descritiva que foi comparada com o estudo longitudinal previamente referido.

Qualquer espécie de pesquisa, em qualquer área, necessita de uma pesquisa bibliográfica prévia, quer para o levantamento do estado da arte do tema, quer para a fundamentação teórica ou ainda para justificar os limites e contribuições da própria pesquisa. Ela constitui parte da pesquisa descritiva, quando é feita com o intuito de recolher informações e conhecimentos prévios acerca de um problema para o qual se procura resposta ou acerca de uma hipótese que se quer experimentar. (CERVO; BERVIAN, 2002, p. 65-66).

\subsection{Método de pesquisa}

Neste estudo, adotou-se o método quantitativo no tratamento dos dados a fim de verificar-se a influência dos incentivos fiscais na estrutura de capital e a rentabilidade das companhias abertas brasileiras não financeiras. Segundo Collis e Hussey (2005, p. 26) o método quantitativo é objetivo por natureza e focado na mensuração de fenômenos, envolvendo a coleta e análise de dados numéricos e a aplicação de testes estatísticos.

\subsection{População-alvo}

A população-alvo do estudo foi constituída pelas companhias abertas brasileiras não financeiras. A escolha da referida população foi motivada pelo interesse deste estudo em avaliar a influência dos incentivos fiscais sobre a estrutura de capital e a rentabilidade das organizações industriais, comerciais e prestadoras de serviços. As instituições financeiras não compuseram a população em virtude das características específicas das suas operações e porque não faz parte do interesse deste estudo. 


\subsection{Variáveis e definições operacionais}

De acordo com Morais (2003), uma variável é qualquer característica mensurável ou descritível do objeto alvo de investigação. Segundo o autor, metricamente uma variável pode ser classificada como nominal (presta-se somente à identificação), ordinal (presta-se à identificação e à ordenação), discreta (corresponde a uma contagem) ou contínua (corresponde a uma medida). Posicionalmente, uma variável pode ser classificada como dependente, independente ou interveniente. Richardson (1999) define variável interveniente como toda variável que, no tempo, pode afetar a estrutura de relacionamento entre as variáveis independentes e dependentes. Cervo e Bervian (2002, p. 87) explicam que variável interveniente é a que modifica a variável dependente sem que tenha havido modificação na variável independente.

Na questão de pesquisa alvo deste estudo consideraram-se como variáveis independentes a dicotomia que descreve a obtenção de incentivo fiscal por parte das empresas (OIF), o valor médio dos incentivos fiscais usufruídos (VMIF), a proporção de anos que a empresa usufruiu dos incentivos fiscais (PAIF) e o número de anos que a empresa usufruiu de incentivos fiscais durante o seu tempo de operação no período (TIF). Como variáveis dependentes consideraram-se a estrutura de capital (medida pelos indicadores LER, DER, DCR) e a rentabilidade (medida pelos indicadores ROA e ROE). Os indicadores de estrutura de capital e de rentabilidade foram avaliados em corte transversal por meio de seus valores médios calculados sobre os 13 anos observados, e, de forma longitudinal, por meio de seus valores anuais. O Quadro 8 exibe a descrição resumida de todas as variáveis envolvidas no estudo. 
Quadro 8 -Descrição das variáveis independentes, dependentes e intervenientes utilizadas no estudo

\begin{tabular}{|c|c|}
\hline Variável & Descrição \\
\hline \multicolumn{2}{|l|}{ Dependentes } \\
\hline \multicolumn{2}{|l|}{$\begin{array}{c}\text { Para o estudo } \\
\text { Transversal }\end{array}$} \\
\hline $\mathrm{ROA}_{\mathrm{m}}$ & ROA médio calculado sobre os 13 períodos observados. Variável do tipo contínua. \\
\hline $\mathrm{ROE}_{\mathrm{m}}$ & ROE médio calculado sobre os 13 períodos observados. Variável do tipo contínua. \\
\hline $\mathrm{LER}_{\mathrm{m}}$ & LER médio calculado sobre os 13 períodos observados. Variável do tipo contínua. \\
\hline $\mathrm{DER}_{\mathrm{m}}$ & DER médio calculado sobre os 13 períodos observados. Variável do tipo contínua. \\
\hline $\mathrm{DCR}_{\mathrm{m}}$ & DCR médio calculado sobre os 13 períodos observados. Variável do tipo contínua. \\
\hline \multicolumn{2}{|l|}{$\begin{array}{l}\text { Para o estudo } \\
\text { Longitudinal }\end{array}$} \\
\hline $\mathrm{ROA}_{\mathrm{i}}$ & ROA em cada período $\mathrm{i}=1995, \ldots, 2007$. Variável do tipo contínua. \\
\hline $\mathrm{ROE}_{\mathrm{i}}$ & ROE em cada período i = 1995, ..., 2007. Variável do tipo contínua. \\
\hline $\mathrm{LER}_{\mathrm{i}}$ & LER em cada período i $=1995, \ldots, 2007$. Variável do tipo contínua. \\
\hline $\mathrm{DER}_{\mathrm{i}}$ & DER em cada período i $=1995, \ldots, 2007$. Variável do tipo contínua. \\
\hline $\mathrm{DCR}_{\mathrm{i}}$ & DCR em cada período i $=1995, \ldots, 2007$. Variável do tipo contínua. \\
\hline \multicolumn{2}{|l|}{ Independente } \\
\hline OIF1s & $\begin{array}{l}\text { Obtenção de Incentivo Fiscal. Variável dummy (dicotômica) que corresponde à existência } \\
\text { ou não do incentivo, sendo que: } 0 \text { (zero) indica a não existência de incentivos e } 1 \text { (um) } \\
\text { indica a existência de incentivos no período. A variável é uma dicotomia. }\end{array}$ \\
\hline VMIF & $\begin{array}{l}\text { Valor Médio do Incentivo Fiscal, em reais, obtido pela empresa no período em estudo } \\
\text { (1995 a 2007). Variável do tipo contínua. }\end{array}$ \\
\hline PAIF & $\begin{array}{l}\text { Proporção de Anos com Incentivo Fiscal. Proporção de anos que a empresa usufruiu de } \\
\text { incentivos fiscais no período de } 1995 \text { a } 2007 \text {. Variável do tipo contínua. }\end{array}$ \\
\hline TIF & $\begin{array}{l}\text { Tempo de Incentivo Fiscal. Número de anos que a empresa usufruiu de incentivos fiscais } \\
\text { durante o tempo em que operou no período de } 1995 \text { a } 2007 \text {. Variável do tipo contínua. }\end{array}$ \\
\hline \multicolumn{2}{|l|}{ Intervenientes } \\
\hline CLASS & Classe das ações negociadas pela empresa. A variável assume 13 categorias nominais. \\
\hline SETOR & Setor de atuação da empresa. A variável assume 19 categorias nominais. \\
\hline TOP & Tempo de Operação. Variável do tipo contínua. \\
\hline $\mathrm{CRESV}_{\mathrm{m}}$ & $\begin{array}{l}\text { Valor médio da taxa unitária de crescimento das vendas no período de } 1995 \text { a } 2007 . \\
\text { Variável do tipo contínua. }\end{array}$ \\
\hline $\mathrm{NT}_{\mathrm{m}}$ & Nível médio de Tributação. Variável do tipo contínua. \\
\hline
\end{tabular}

O ROA (Return on Assets) corresponde à razão entre o lucro líquido do exercício e o total do ativo e o ROE (Return on Equity) é definido como a razão entre o lucro líquido do exercício e o total do patrimônio líquido. De acordo com Palepu et al. (2004), o ROA e o ROE são indicadores do retorno do ativo e do patrimônio líquido, respectivamente.

O LER (Liabilities-to-equity ratio) é a razão entre o capital de terceiros e o capital próprio; o DER (Debt-to-equity ratio) é a razão entre a soma dos financiamentos de curto e longo prazo e o patrimônio líquido, e DCR (Debt-to-capital ratio) é a razão entre a soma dos financiamentos de curto e longo prazo e a soma dos financiamentos de curto e longo prazo 
mais o patrimônio líquido. Oportuno observar que, também, de acordo com Palepu et al. (2004) o LER, o DER e o DCR são importantes indicadores da estrutura de capital de uma empresa.

$\mathrm{O}$ uso da média dos indicadores $\mathrm{ROA}_{\mathrm{m}}, \mathrm{ROE}_{\mathrm{m}}, \mathrm{LER}_{\mathrm{m}}, \mathrm{DER}_{\mathrm{m}}, \mathrm{DCR}_{\mathrm{m}}$ foi motivado pela Normalidade da distribuição dos referidos indicadores para cada uma das 590 empresas o que, segundo Lang (2004), recomenda o uso da média como medida sumária de dados.

As variáveis indexadas com i $=1995, \ldots, 2007$ representam as variáveis utilizadas na análise longitudinal dos dados. Assim, $\mathrm{ROA}_{\mathrm{i}}, \mathrm{ROE}_{\mathrm{i}}, \mathrm{LER}_{\mathrm{i}}, \mathrm{DER}_{\mathrm{i}}, \mathrm{DCR}_{\mathrm{i}}$ correspondem aos indicadores de estrutura e retornos avaliados para cada um dos períodos e cada uma das empresas.

A classificação das ações e dos setores considerando os critérios adotados pela Economática foram os seguintes:

\section{Classe:}

De acordo com a Economática as classes de ações são as seguintes: (1)=A, (2)=AN, (3)=BN, $(4)=\mathrm{ON}, \quad(5)=\mathrm{ONA}, \quad(6)=\mathrm{PN}, \quad(7)=\mathrm{PNA}, \quad(8)=\mathrm{PNB}, \quad(9)=\mathrm{PNC}, \quad(10)=\mathrm{PND}, \quad(11)=\mathrm{PNF}$, (12)=PNG, (13)=UNT N2. Para efeito deste estudo, optou-se pela adoção de 5 classes: $(1)=A$ e AN, sendo denominada classe $A ;(2)=B N$, sendo denominada classe $B ;(3)=O N$ e ONA, sendo denominada classe ON; (4)=PN, PNA, PNB, PNC, PND, PNF e PNG, sendo denominada classe PN, e (5)=UNT N2, sendo denominada classe UNT.

\section{Setores:}

Ainda, de acordo com a Economática, os setores são os seguintes: (1)=Agro e Pesca, (2)=Alimentos e Bebidas, (3)=Comércio, (4)=Construção, (5)=Eletroeletrônicos, (6)=Energia Elétrica, (7)=Máquinas Industriais, (8)=Mineração, (9)=Minerais não Metálicos, (10)=Papel e celulose, (11)=Petróleo e Gás, (12)=Química, (13)=Siderurgia e Metalurgia, (14)=Software e Dados, (15)=Telecomunicações, (16)=Têxtil, (17)=Transporte e Serviços, (18)=Veículos e Peças, (19)=Outros. Para efeito deste estudo, optou-se pela adoção da seguinte classificação: (1)=Agro/Pesca, Alimentos/Bebidas e Comércio, sendo designado por Comércio; (2)=Construção; (3)=Eletroeletrônicos e Softwares/Dados; (4)=Energia Elétrica, (5)=Máquinas Industriais; (6)=Mineração e Minerais não Metálicos; (7)=Papel e celulose; 
(8)=Petróleo e Gás; (9)=Química; (10)=Siderurgia e Metalurgia; (11)=Telecomunicações; (12)=Têxtil; (13)=Transporte/Serviços e Veículos/Peças, (14)=Outros.

As variáveis: nível médio de tributação, tempo de operação da empresa e tempo que a empresa usufruiu de incentivos fiscais foram avaliadas no período de 13 anos.

A taxa unitária de crescimento das vendas de uma dada empresa no ano i com base no ano i-1 foi indicada por TCRES $V_{\mathrm{i}, \mathrm{i}-1}$ e dada pela relação:

$$
T C R E S V_{i, i-1}=\frac{\text { Volume.de..vendas.no...ano...i }}{\text { Volume.de...vendas..no...ano }-1}-1
$$

Para a análise transversal dos dados, definiu-se, para cada empresa, a variável CRESV $\mathrm{m}_{\mathrm{m}}$ que corresponde ao valor médio da taxa unitária de crescimento das vendas avaliada sobre os períodos com efetiva observação de vendas. Assim, por exemplo, se uma empresa no período apresentou somente vendas nos anos de 2004, 2005 e 2006 dadas por 20.000, 25.000 e 30.000, respectivamente, então:

$$
\operatorname{TCRESV}_{2005,2004}=\frac{25.000}{20.000}-1=0,25 \quad \text { e } \quad T C R E S V_{2006,2005}=\frac{30.000}{25.000}-1=0,2
$$

e, desse modo, tem-se que:

$$
C R E S V_{m}=\frac{0,25+0,20}{2}=0,225
$$

Para o cômputo do Nível Médio de Tributação, calculou-se a razão entre o IR e o LAIR para cada período e, em seguida, considerou-se, para cada empresa, a média aritmética simples dessas razões.

Com base no exposto no referencial teórico, de forma geral, os incentivos fiscais são instrumentos baseados em desoneração tributária, cujo objetivo é alcançar o bem comum.

Embora, juridicamente, exista diferença entre benefícios fiscais e incentivos fiscais, na prática não é feita nenhuma distinção entre ambos e, ainda, economicamente, ambos causam efeitos 
semelhantes. Neste estudo, foi considerado como incentivo fiscal a desoneração tributária, seja decorrente do acréscimo da despesa pública ou da renúncia de receita pública, cujos efeitos foram mensurados e registrados nas demonstrações financeiras das empresas. Fazem parte desse gênero: as isenções, as reduções de alíquota e de base de cálculo, as subvenções, os créditos presumidos e os subsídios.

Considerando-se que as empresas, por definição, são diferentes entre si em função de uma combinação de elementos que as caracterizam em termos da forma de constituição, estrutura, ramo de atuação e região, dentre outros, outras variáveis que caracterizam as empresas da amostra foram inseridas na coleta de dados.

\subsection{Amostra}

Como amostra foram selecionadas todas as companhias abertas brasileiras não financeiras com ações negociadas na Bovespa. A Tabela 1 exibe a formação da amostra de empresas e dos registros contábeis considerados no estudo. De acordo com a tabela, das 653 companhias abertas brasileiras com ações na Bovespa, 590 foram empresas não financeiras perfazendo um número potencial de registros contábeis de 7.670 no período. Considerando o número de registros contábeis ligados aos indicadores de estrutura e rentabilidade, observou-se uma variação de 4645 a 4670 registros no período. 
Tabela 1 - Formação da amostra de empresas e de registros contábeis considerada neste estudo

\begin{tabular}{|c|c|c|c|c|c|c|}
\hline \multicolumn{6}{|c|}{ Discriminação } & \multirow{2}{*}{$\begin{array}{c}\mathbf{n} \\
653\end{array}$} \\
\hline \multicolumn{6}{|c|}{ Total de empresas presentes no banco de dados (população) } & \\
\hline \multicolumn{6}{|c|}{ Empresas que atuam na atividade financeira } & 63 \\
\hline \multicolumn{6}{|c|}{ Número de empresas constantes da amostra final } & 590 \\
\hline \multicolumn{6}{|c|}{ Número de anos considerados para cada empresa } & 13 \\
\hline \multicolumn{6}{|c|}{ Número total de potenciais observações compreendidas na amostra final } & 7.670 \\
\hline ANO & EMPRESA & ROA & ROE & LER & DER & DCR \\
\hline 1995 & 590 & 275 & 275 & 275 & 274 & 274 \\
\hline 1996 & 590 & 288 & 288 & 288 & 287 & 287 \\
\hline 1997 & 590 & 347 & 347 & 348 & 346 & 346 \\
\hline 1998 & 590 & 421 & 421 & 423 & 420 & 420 \\
\hline 1999 & 590 & 421 & 421 & 423 & 420 & 420 \\
\hline 2000 & 590 & 400 & 401 & 402 & 401 & 401 \\
\hline 2001 & 590 & 382 & 382 & 383 & 378 & 378 \\
\hline 2002 & 590 & 365 & 366 & 367 & 365 & 365 \\
\hline 2003 & 590 & 345 & 345 & 346 & 344 & 344 \\
\hline 2004 & 590 & 346 & 347 & 349 & 348 & 348 \\
\hline 2005 & 590 & 344 & 344 & 348 & 345 & 345 \\
\hline 2006 & 590 & 360 & 359 & 360 & 360 & 360 \\
\hline 2007 & 590 & 358 & 358 & 358 & 357 & 357 \\
\hline TOTAL & 7670 & 4652 & 4654 & 4670 & 4645 & 4645 \\
\hline
\end{tabular}

Ressalte-se que não foram excluídas as empresas que:

a) apresentaram prejuízo contábil;

b) apresentaram prejuízo contábil e apuraram imposto de renda a pagar;

c) apresentaram lucro contábil e apuraram uma receita de imposto de renda, ou seja, o imposto de renda foi somado ao lucro antes do imposto de renda como uma receita de imposto;

d) apresentaram prejuízo contábil e apuraram uma receita de imposto de renda, ou seja, o imposto de renda foi somado ao lucro antes do imposto de renda como uma receita de imposto.

Conforme abordado na página 103, a evidenciação do lucro contábil, no Brasil, pode conduzir às situações apresentadas nos itens b, c e d acima que, embora, aparentemente, irracionais, são realidades decorrentes da legislação brasileira e, assim, não foram desconsideradas no tratamento dos dados. 


\subsection{Procedimento de coleta de dados}

As informações sobre as variáveis primárias, utilizadas neste estudo, foram coletadas do banco de dados da Economática ${ }^{15}$, relativamente às demonstrações contábeis encerradas pelas companhias abertas nos anos de 1995 a 2007. A informação sobre a empresa usufruir ou não de incentivos fiscais, também, foi coletada desse mesmo banco de dados.

\subsection{Tratamento dos dados}

Os procedimentos estatísticos só devem ser aplicados após o pesquisador cumprir determinadas exigências, condições e suposições. Após a análise e correção dos problemas específicos do banco de dados coletados, foram efetuados os procedimentos estatísticos correspondentes.

Tendo em vista que foram coletadas informações sobre 590 empresas ao longo de 13 anos (1995 a 2007) foi realizado um estudo TRANSVERSAL (sobre as 590 empresas) e um estudo LONGITUDINAL (sobre as 13 x $590=7670$ potenciais observações). Oportuno observar que nem todas as empresas apresentaram dados para todas as variáveis em todos os 13 períodos considerados.

Para o estudo transversal, o objeto de investigação foi a empresa com ação negociada na Bovespa, consistindo em 590 empresas. Para o estudo longitudinal, o objeto foi a informação contábil da empresa no período i (i=1995 a 2007) totalizando 7670 potenciais registros, correspondentes as 590 empresas nos 13 anos investigados.

Os dados foram organizados em tabelas, gráficos e medidas resumo e sofreram uma análise descritiva. Variáveis do tipo contínuas com distribuição normal foram apresentadas na forma MEDIA \pm DP [MIN-MAX]; variáveis contínuas que não apresentaram distribuição normal foram apresentadas na forma MEDIANA (Q1-Q3)[MIN-MAX] e variáveis qualitativas foram

\footnotetext{
${ }^{15}$ O programa Economática é utilizado para fazer análises econômico-financeiras de empresas (http://www.economatica.com.br).
} 
descritas por meio de sua distribuição de freqüências. Para avaliar a precisão da estimativa da proporção de companhias abertas brasileiras incentivadas no período de 1995 a 2007 utilizouse um intervalo de confiança de 95\% (IC95\%) para a proporção. Se p é a proporção amostral de companhias que receberam o incentivo, então o IC95\% para a referida proporção será dado por:

$$
I C 95 \%=p \pm 1,96 \sqrt{\frac{p(1-p)}{n}}
$$

Sempre que possível foram construídos gráficos de intervalos de confiança de $95 \%$ (Error Bar Graph) para a realização de comparações múltiplas. Para investigar a Normalidade da distribuição das variáveis contínuas, adotou-se o teste de normalidade de KolmogorovSmirnov. (BUSSAB; MORETTIN, 2002).

$\mathrm{Na}$ análise transversal os indicadores de incentivo fiscal, estrutura de capital e rentabilidade, para cada empresa, foram reduzidos aos seus valores médios. Foi gerada, dessa forma, uma matriz contendo 590 observações. A comparação dos indicadores de estrutura de capital e rentabilidade nos grupos definidos pela dicotomia que descreve a obtenção de incentivos fiscais foi realizada por meio do teste $U$ de Mann-Whitney para amostras independentes devido à não Normalidade da distribuição dos indicadores nos referidos grupos (SIEGEL, 1956). A Análise de Homogeneidade (HOMALS) foi utilizada na construção de mapas perceptuais envolvendo a dicotomia Obtenção de Incentivos Fiscais, Classe de Ações, Setor de Atividade e as formas categóricas do Tempo de Operação, Nível de Tributação e Crescimento das Vendas. Oportuno observar que nos mapas perceptuais os objetos têm uma posição espacial que reflete a similaridade ou preferência relativa a outros objetos no que se refere as dimensões (eixos) do mapa. No contexto da HOMALS, os mapas perceptuais exibem as associações em um conjunto de variáveis categóricas nominais, permitindo, dessa forma, um exame visual de qualquer padrão ou estrutura nos dados. Fávero et al. $(2006$, p. 7) acrescentam que:

Categorias com localização próxima na projeção plana têm relação mais forte do que categorias separadas por distâncias maiores. Quando categorias de uma mesma variável encontram-se em posições próximas de seus conteúdos semânticos, elas podem ser consideradas iguais no que tange à distribuição de massas do total das observações realizadas. 
Para avaliar o efeito da obtenção de incentivos fiscais sobre os indicadores da estrutura de capital e rentabilidade considerou-se o procedimento GLM Univariate Test As Figuras 18 e 19 apresentam uma síntese da análise transversal efetuada neste estudo.

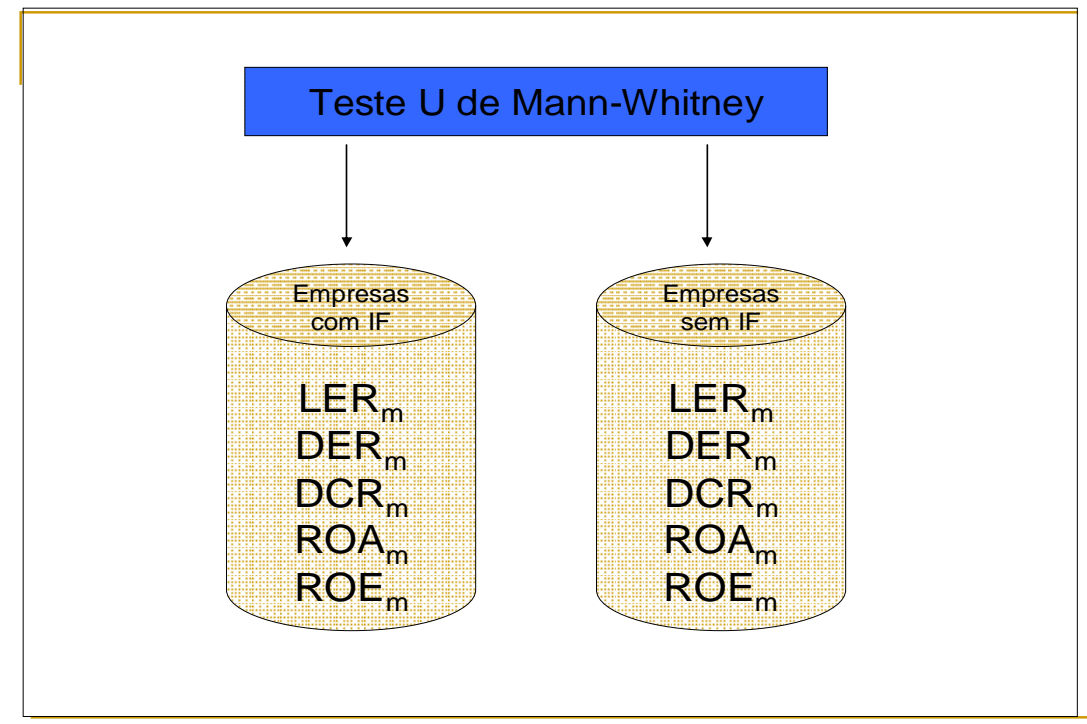

Figura 18 - Análise Transversal por meio do Teste U de Mann-Whitney

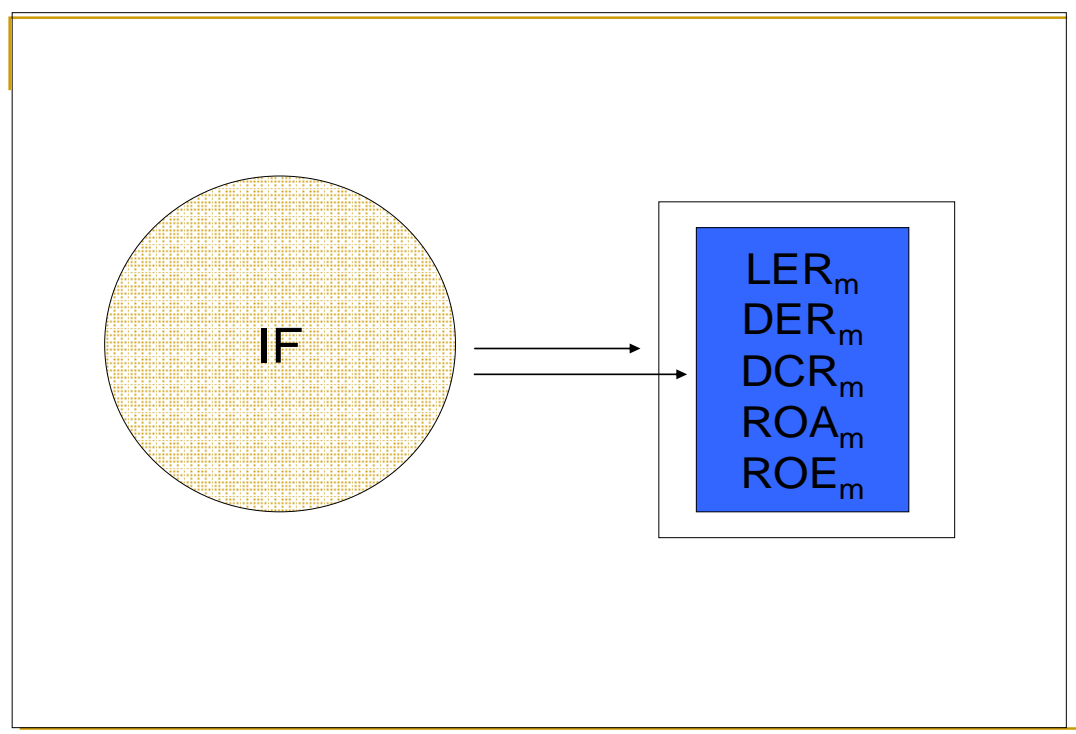

Figura 19 - Análise Transversal por meio do GLM Univariate Test

$\mathrm{Na}$ análise longitudinal, considerou-se o procedimento GLM Multivariate Test (NELDER; WEDDERBURN, 1972) na avaliação do efeito da obtenção de incentivos fiscais e do ano em 
que a operação contábil foi realizada sobre os indicadores de estrutura de capital e rentabilidade. A Figura 20 apresenta uma síntese da análise longitudinal.

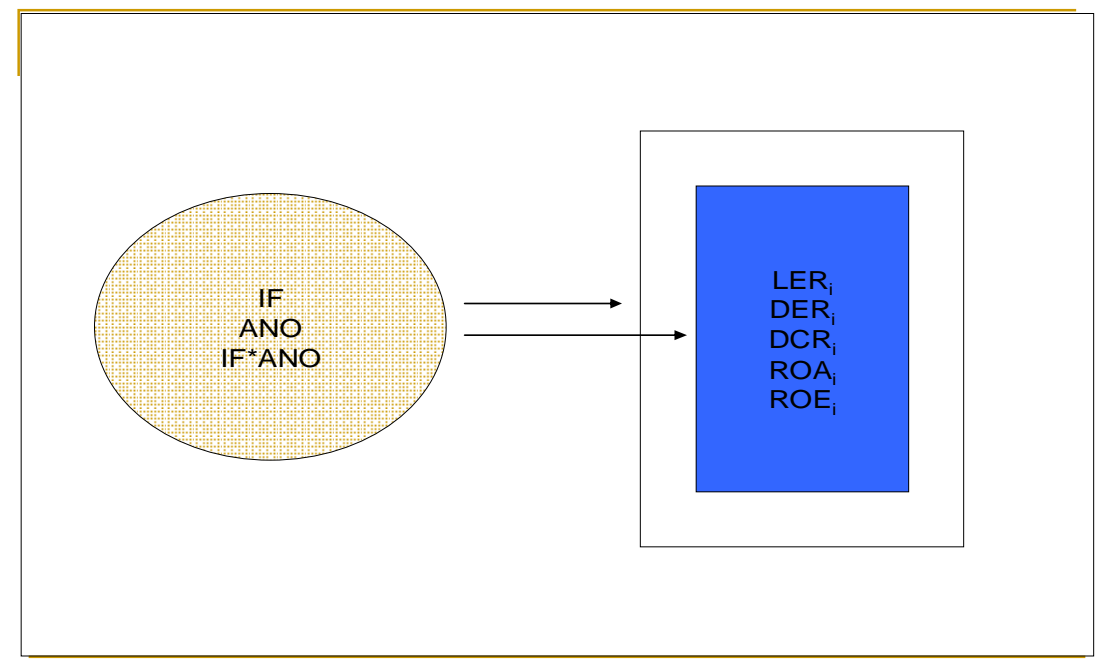

Figura 20 - Análise Longitudinal por meio do GLM Multivariate Test

O Modelo Linear Geral (GLM) é um modelo estatístico que pode ser escrito na forma:

$$
\mathbf{Y}=\mathbf{X B}+\mathbf{U}
$$

em que: $\mathrm{Y}_{\mathrm{n} \text { x k }}$ e $\mathrm{X}_{\mathrm{n} \text { x r }}$ são matrizes cujas colunas são variáveis aleatórias; $\mathrm{B}_{\mathrm{r} \text { x k }}$ é uma matriz de parâmetros estimáveis e $\mathrm{U}_{\mathrm{n} \times \mathrm{k}}$ é uma matriz de erros usualmente assumida como tendo distribuição normal multivariada.

No contexto da Análise de Regressão (base de muitas das técnicas estatísticas multivariadas), sendo $\mathrm{k}=1$, Y é uma variável aleatória quantitativa; $\mathrm{X}$ é uma matriz na qual a primeira coluna é formada por $1 \mathrm{~s}$ e as demais colunas podem ser variáveis quantitativas ou variáveis indicadoras de grupos; B é uma matriz contendo r parâmetros estimáveis pelo método dos mínimos quadrados e U é uma matriz de variáveis aleatórias com distribuição normal com média 0 e variância constante .

No contexto da Análise de Variância (ANOVA), Y é uma matriz com uma variável aleatória quantitativa; X é uma matriz cuja primeira coluna é composta de $1 \mathrm{~s}$ e as demais colunas representam variáveis indicadoras que identificam os grupos de comparação. Nesse modelo, 
B é uma matriz que inclui os parâmetros de efeito dos grupos. U é uma matriz de erros com distribuição normal multivariada.

No caso do GLM Univariate referido, tem-se:

$Y_{j}=\left(R_{j}, R_{j}, L_{j}, D_{j} R_{j}, D R_{j}\right)$, em que: $j=1,2, \ldots 590$,

$$
X=\left[\begin{array}{ccc}
1 & 1 & 0 \\
1 & 1 & 0 \\
\cdots & \cdots & \cdots \\
1 & 1 & 0 \\
1 & 0 & 1 \\
1 & 0 & 1 \\
\cdots & \cdots & \cdots \\
1 & 0 & 1
\end{array}\right]_{590 \times 3}
$$

A matriz X tem dimensão 590 x 3, isto é , tem 590 linhas e 3 colunas. As 419 primeiras linhas referem-se a empresas sem incentivo fiscal. Nesse sentido, as duas primeiras colunas dessa parte da matriz serão formadas por 1s enquanto a última será formada por 0s. As últimas 171 linhas da matriz referem-se a empresas com incentivo fiscal, assim, nessa parte da matriz, a primeira e a última coluna serão formadas por $1 \mathrm{~s}$ enquanto a segunda coluna será formada por 0s.

$$
B=\left[\begin{array}{lllll}
\mu_{1} & \mu_{2} & \mu_{3} & \mu_{4} & \mu_{5} \\
\tau_{01} & \tau_{02} & \tau_{03} & \tau_{04} & \tau_{05} \\
\tau_{11} & \tau_{12} & \tau_{13} & \tau_{14} & \tau_{15}
\end{array}\right]_{3 x 5}
$$

Observe-se na matriz B acima que:

$\mu_{\mathrm{i}}=$ efeito médio do indicador i que independe do incentivo fiscal;

$\tau 0 \mathrm{i}=$ efeito da ausência de incentivo fiscal sobre o indicador $\mathrm{i}$;

$\tau 1 \mathrm{i}=$ efeito da presença de incentivo fiscal sobre o indicador $\mathrm{i}$;

$\mathrm{i}=$ ROA; ROE; LER; DER; DCR; sendo j = 1, 2, 3, ... , 590;

$\mathrm{U}_{\mathrm{j}}=\left(\mathrm{U}_{\mathrm{ROAj}}, \mathrm{U}_{\mathrm{ROEj}}, \mathrm{U}_{\mathrm{LER} \mathrm{j}}, \mathrm{U}_{\text {DERj }}, \mathrm{U}_{\mathrm{DCRj}}\right)$, em que: $\mathrm{j}=1,2, \ldots 590$, 
No caso do GLM Multivariate referido, as informações avaliadas levaram em conta a variável tempo, isto é, as matrizes $\mathrm{Y}, \mathrm{X}, \mathrm{B}$ e $\mathrm{U}$ dependeram do ano avaliado.

O GLM é um modelo que incorpora diferentes outros modelos estatísticos, tais como a Análise de Variância (ANOVA) e Análise Multivariada de Variância (MANOVA). Se existe apenas uma coluna em Y (isto é, uma única variável dependente), então, o modelo pode, também, ser referido como um modelo de regressão múltipla.

De acordo com Malhotra (2001), a MANOVA é uma técnica multivariada, introduzida originalmente por Wilks (1932, apud Hair et al., 2005, p. 271), semelhante à ANOVA, exceto quanto ao fato de haver duas ou mais variáveis dependentes métricas e não apenas uma. $\mathrm{O}$ objetivo da técnica é o mesmo da ANOVA: examinar diferenças entre grupos. Enquanto a ANOVA examina diferenças de grupos para uma única variável dependente, a MANOVA estuda diferenças de grupos simultaneamente ao longo de múltiplas variáveis dependentes. $\mathrm{Na}$ ANOVA, a hipótese nula é que as médias da variável dependente são iguais através dos grupos. Na MANOVA, a hipótese nula é que o vetor de médias sobre variáveis dependentes múltiplas é o mesmo entre grupos. A MANOVA é apropriada quando há duas ou mais variáveis dependentes correlacionadas. Se há múltiplas variáveis dependentes nãocorrelacionadas ou ortogonais, a ANOVA aplicada a cada uma das variáveis dependentes é mais apropriada do que a MANOVA.

No presente estudo, a escolha da MANOVA (desenvolvida mediante o procedimento GLM) foi motivada pelo fato de a metodologia combinar de maneira ótima as múltiplas medidas dependentes em um único valor denominado Variável Estatística ${ }^{16}$ que maximiza as diferenças ao longo dos grupos.

Ressalte-se que, em todas as análises, foram calculados os $p$ associados às hipóteses de nulidade de cada teste. Toda diferença, correlação ou medida de efeito cujo $p$ - value foi inferior a 0,05 foi considerada, estatisticamente, significante. A base de dados foi construída e gerenciada no software MSOffice Excel ${ }^{\circledR}$ v. 2007 e o tratamento dos dados foi realizado no software SPSS ${ }^{\circ}$ v. 15.

\footnotetext{
${ }^{16}$ A combinação de variáveis em análise multivariada é denominada variável estatística. (HAIR et al., 2005).
} 


\section{APRESENTAÇÃO E TRATAMENTO DOS DADOS E ANÁLISE DOS RESULTADOS}

\subsection{Análise descritiva}

Com o propósito de estabelecer o perfil quantitativo das empresas envolvidas no estudo construíram-se as distribuições de freqüência das principais variáveis de caracterização das referidas empresas. A Figura 21 apresenta a distribuição das empresas de acordo com a obtenção de incentivo fiscal no período de 1995 a 2007 e a Tabela 2 exibe a distribuição das variáveis Classe da ação e Setor de atividade no mesmo período. A Figura 22 exibe o mapa perceptual das variáveis Obtenção do incentivo fiscal, Classe da ação e Setor de atividade.

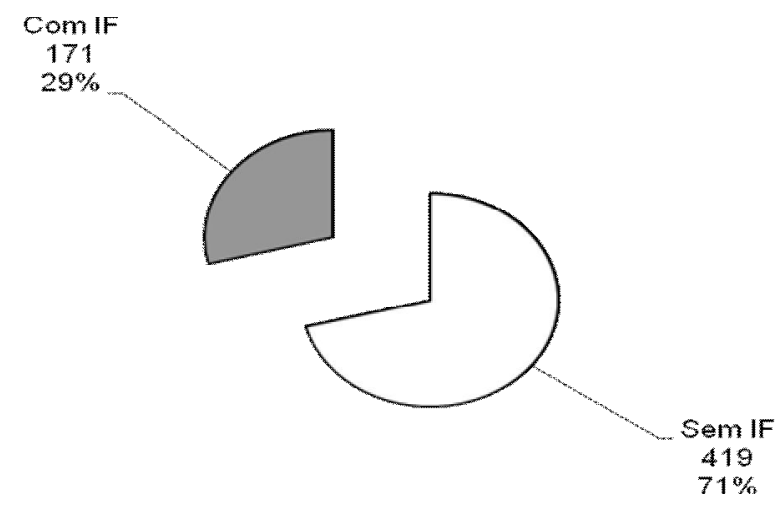

Figura 21 - Distribuição das empresas de acordo com a obtenção do incentivo fiscal

Observe-se que a grande maioria das empresas (71\%) não obteve qualquer incentivo fiscal no período de 1995 a 2007. Com base na proporção de empresas incentivadas na amostra (29\%) é possível estimar, com 95\% de confiança, que o percentual de companhias abertas brasileiras não financeiras que usufruiram de incentivo fiscal no período de 1995 a 2007 oscila de $25,34 \%$ a $32,55 \%$. 
Tabela 2 - Distribuição das empresas de acordo com a obtenção de incentivo fiscal,

o tipo de ação e o setor de atividade

\begin{tabular}{|c|c|c|c|c|c|c|}
\hline \multirow[b]{2}{*}{ Classe } & \multicolumn{2}{|c|}{$\begin{array}{c}\text { Global } \\
(590)\end{array}$} & \multicolumn{2}{|c|}{$\begin{array}{c}\text { Sem incentive } \\
(419)\end{array}$} & \multicolumn{2}{|c|}{$\begin{array}{c}\text { Com incentivo } \\
\text { (171) }\end{array}$} \\
\hline & $\mathbf{N}$ & $\%$ & $\mathbf{n}$ & $\%$ & $\mathbf{N}$ & $\%$ \\
\hline $1=\mathrm{A}$ & 15 & 2,5 & 11 & 2,6 & 4 & 2,3 \\
\hline $2=B$ & 9 & 1,5 & 7 & 1,7 & 2 & 1,2 \\
\hline $3=\mathrm{ON}$ & 227 & 38,5 & 168 & 40,1 & 59 & 34,5 \\
\hline $4=\mathrm{PN}$ & 330 & 55,9 & 224 & 53,5 & 106 & 62,0 \\
\hline $5=\mathrm{UNT}$ & 9 & 1,5 & 9 & 2,1 & 0 & 0,0 \\
\hline \multicolumn{7}{|l|}{ Setor } \\
\hline 1=Comércio & 80 & 13,6 & 54 & 12,9 & 26 & 15,2 \\
\hline 2=Construção & 41 & 6,9 & 39 & 9,3 & 2 & 1,2 \\
\hline $3=$ Eletroeletrônicos & 23 & 3,9 & 15 & 3,6 & 8 & 4,7 \\
\hline 4=Energia Elétrica & 54 & 9,2 & 48 & 11,5 & 6 & 3,5 \\
\hline 5=Máquinas Industriais & 11 & 1,9 & 6 & 1,4 & 5 & 2,9 \\
\hline 6=Mineração & 19 & 3,2 & 12 & 2,9 & 7 & 4,1 \\
\hline $7=$ Papel e Celulose & 10 & 1,7 & 8 & 1,9 & 2 & 1,2 \\
\hline 8=Petróleo e Gás & 9 & 1,5 & 4 & 1,0 & 5 & 2,9 \\
\hline 9=Química & 40 & 6,8 & 19 & 4,5 & 21 & 12,3 \\
\hline $10=$ Siderurgia e Metalurgia & 51 & 8,6 & 36 & 8,6 & 15 & 8,8 \\
\hline 11=Telecomunicações & 64 & 10,8 & 39 & 9,3 & 25 & 14,6 \\
\hline 12=Têxtil & 39 & 6,6 & 23 & 5,5 & 16 & 9,4 \\
\hline 13=Veículos e Transportes & 47 & 8,0 & 37 & 8,8 & 10 & 5,8 \\
\hline $14=$ Outros & 102 & 17,3 & 79 & 18,9 & 23 & 13,5 \\
\hline
\end{tabular}

Os dados contidos na Tabela 2 evidenciam um predomínio de ações dos tipos PN (55,9\%, $53,5 \%$ e $62,0 \%$ no conjunto das empresas, nas empresas sem incentivo e com incentivo, respectivamente) e ON $(38,5 \%, 40,1 \%$ e $34,5 \%$ no conjunto das empresas, nas empresas sem e com incentivo, respectivamente). Para a variável Setor de atividade, exclusive o setor "outros", observe-se uma predominância do setor comercial $(13,6 \%, 12,9 \%$ e 15,2\% no conjunto das empresas, nas empresas sem e com incentivo, respectivamente). 


\section{Quantifications}

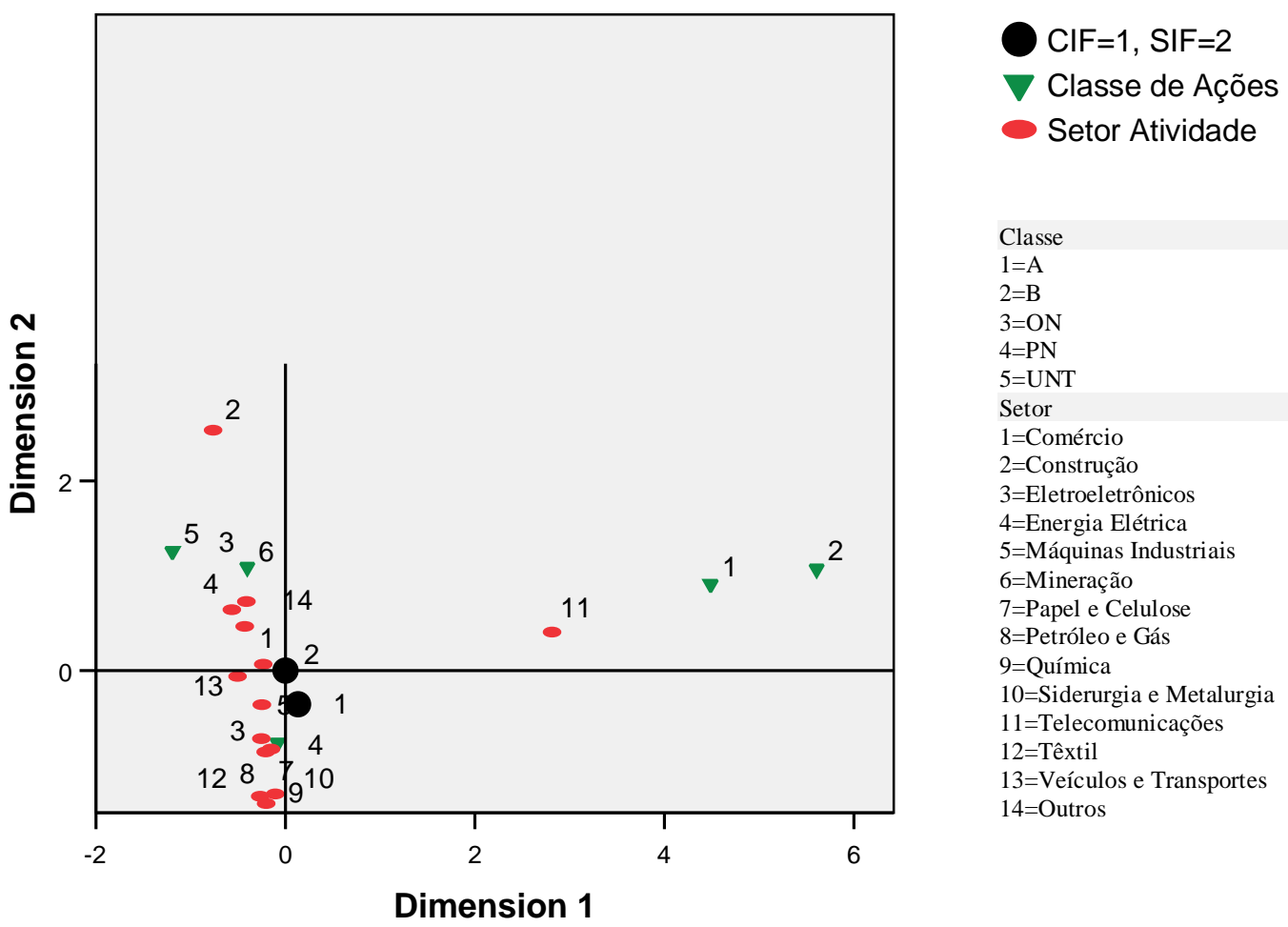

Figura 22 - Mapa perceptual das variáveis incentivo fiscal, classe da ação e setor de atividade: análise de homogeneidade (HOMALS)

A visualização do mapa perceptual, contido na Figura 22, permite observar 3 (três) grupos de empresas similares quanto à classe de ações: (1) empresas com ações do tipo A e B; (2) com ações do tipo ON e UNT e (3) com ações do tipo PN. Também é possível identificar que empresas com ações do tipo B parecem ser as menos incentivadas enquanto as com ações do tipo PN parecem ser as mais incentivadas.

Com relação ao setor de atividade, o mapa perceptual sugere que os setores de construção e telecomunicações são os que mais se distanciam dos demais setores bem como os que parecem menos se beneficiar dos incentivos. Além disso, os setores de eletroeletrônicos e máquinas industriais apresentam-se como os mais beneficiados pelos incentivos. Observe-se uma grande proximidade do setor comercial e de energia com o ponto de ausência de incentivos, sugerindo que empresas desses setores tendem a não obter incentivos. 
A Figura 23 permite a comparação da proporção de empresas de cada setor nos grupos definidos pela obtenção ou não de incentivos.

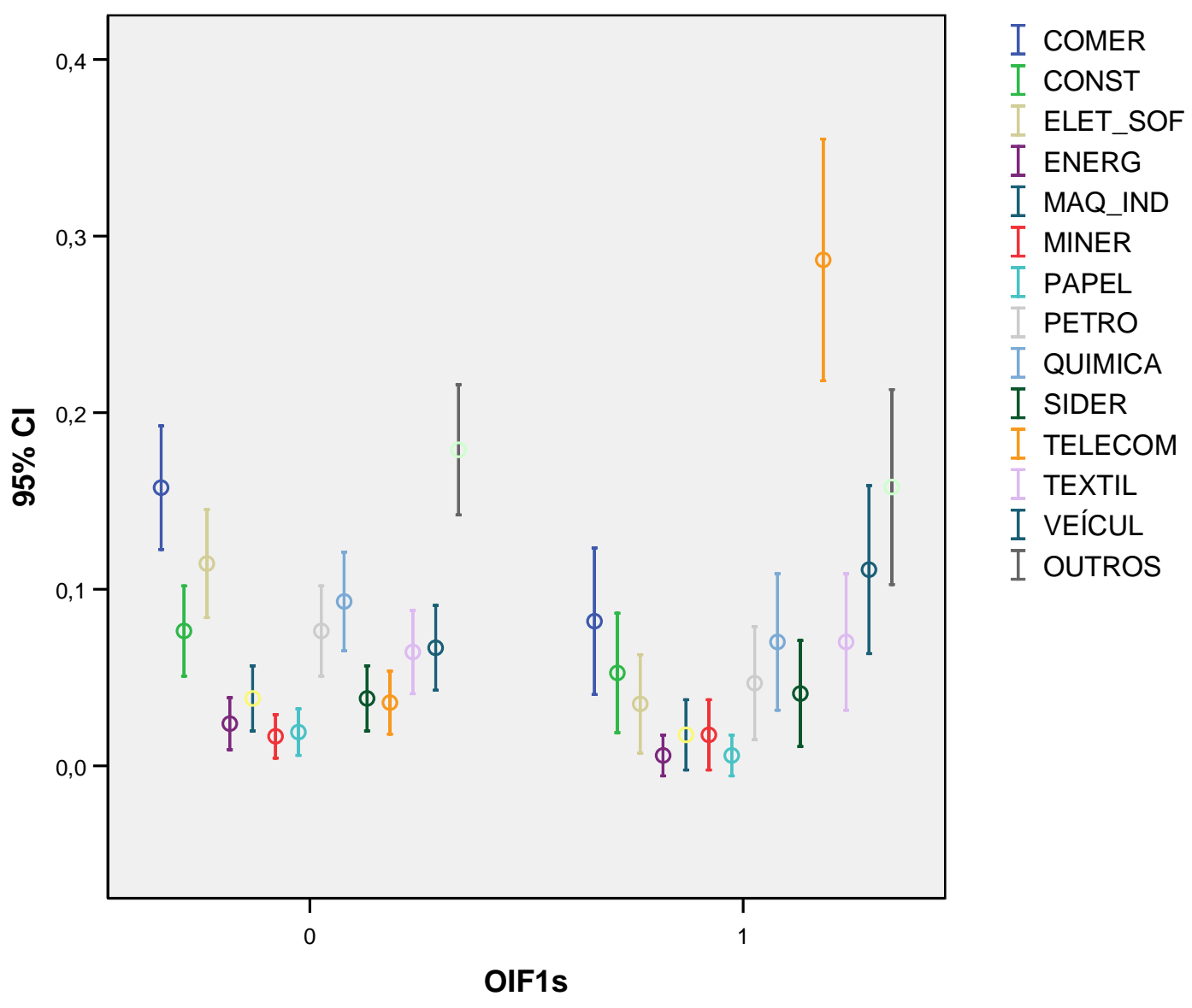

Figura 23 - Error Bar de proporções de empresas em cada setor de estudo com e sem incentivo fiscal

A Figura 23 exibe, graficamente, estimativas intervalares para proporção de empresas ligadas aos setores em estudo para empresas sem e com incentivo fiscal. Na referida figura, os setores são identificados em cada grupo pela mesma cor. De acordo com o método de análise utilizado em Castilho (2002), podem-se realizar comparações gerais entre as referidas proporções de acordo com a posição relativa do centro de cada intervalo. Dois intervalos que têm os centros contidos nas braças um do outro sugerem que a diferença entre as proporções na população estudada não é estatisticamente significativa; por outro lado, se os dois centros não estiverem contidos reciprocamente cada um nas braças do outro, sugere diferença significativa, favorecendo o intervalo que se encontra em posição mais elevada no quadro. Caso somente um dos centros esteja contido nas braças do outro, isso sugere incerteza quanto à comparação. 
O exame da Figura 23, considerando o método relatado por Castilho (2002), sugere ausência de diferença entre os grupos no que tange à proporção de empresas dos setores: Construção, Mineração, Química e Siderurgia/Metalurgia (isto é, não se identifica associação entre a obtenção de incentivo fiscal e a pertinência a qualquer um dos setores). Não foi possível aferir julgamento para os setores de Petróleo/Gás e Veículos/Transportes. Na Figura 23 identifica-se diferença entre os grupos (sem e com incentivo), favorecendo o grupo de empresas sem incentivo nos setores Comercio, Eletroeletrônicos/Softwares, Energia, Máquinas Industriais e Papel/Celulose (isto é, empresas desses setores tendem a não apresentar incentivos fiscais). Somente no setor das Telecomunicações, observa-se um favorecimento do grupo de empresas com incentivo fiscal (isto é, empresas do setor de Telecomunicações tendem a obter incentivos fiscais). Oportuno observar que a associação identificada entre incentivos fiscais e os setores Comércio e Energia, bem com a ausência de correlação entre os setores referidos na análise da Figura 23 foram corroborados pelo mapa perceptual contido na Figura 22.

A Tabela 3 exibe a distribuição de freqüências e medidas resumo das variáveis: Tempo de Operação, Tempo de Incentivo Fiscal, Nível de Tributação e Valor Médio da Taxa Unitária de Crescimento Anual das Vendas das empresas. A Figura 20 exibe o mapa perceptual das variáveis para o conjunto das empresas. 
Tabela 3 - Distribuição de freqüências e medidas resumo das variáveis: tempo de operação, tempo de incentivo fiscal, taxa unitária do nível de tributação e taxa unitária do crescimento médio anual das vendas

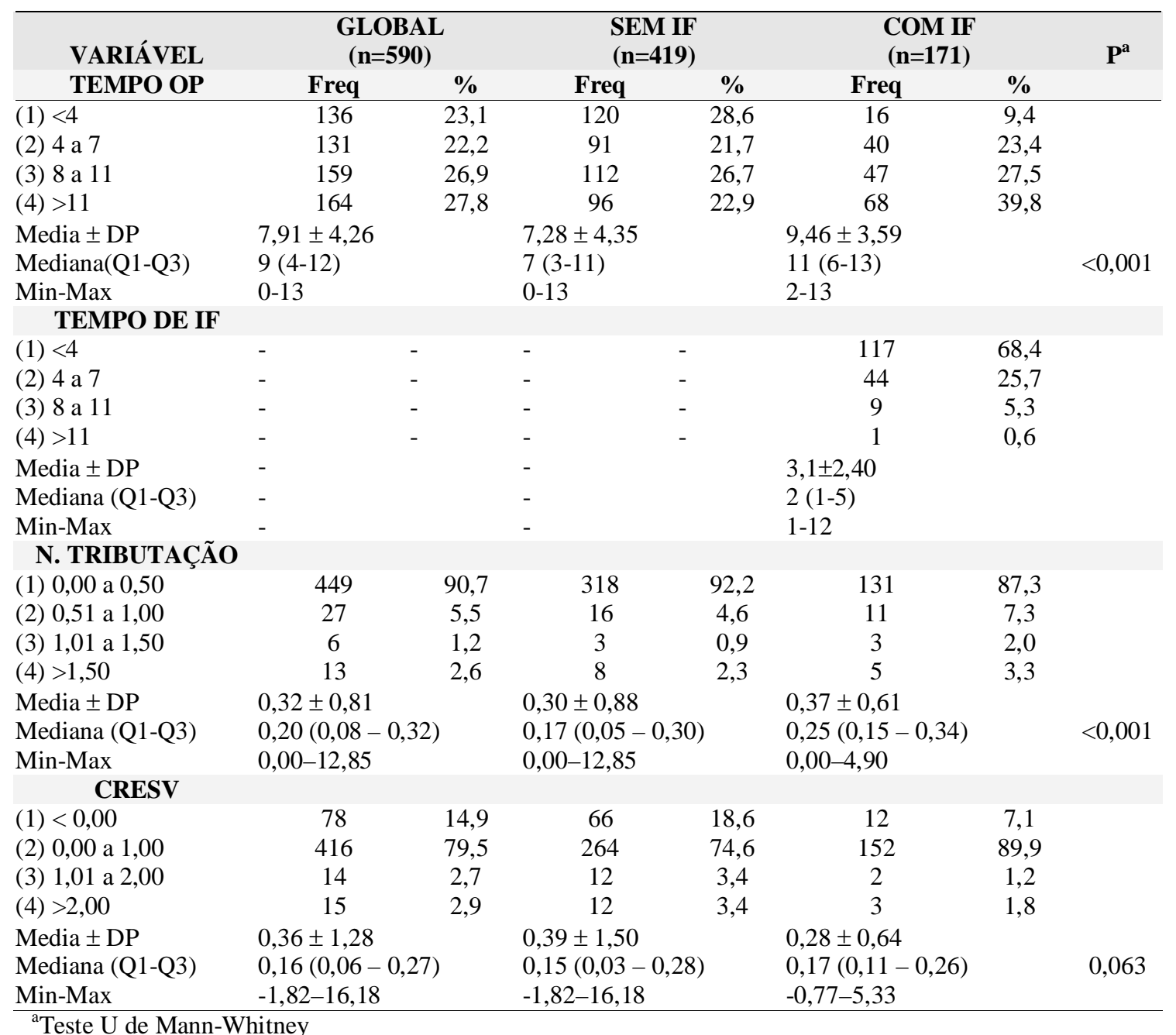

O exame dos dados contidos na Tabela 3 evidencia, para o conjunto das empresas $(n=590)$, uma sutil predominância de organizações com mais de 7 anos de tempo de operação $(54,7 \%)$; um tempo médio de operação $7,91(\mathrm{DP}=4,26)$ e variação de 0 a 13 anos. Cerca de $25 \%$ das empresas operaram menos de 4 anos; $50 \%$ operaram menos de 9 anos e 25\% operaram mais de 12 anos. Para a variável tempo de incentivo fiscal, observe-se uma acentuada predominância $(90,8 \%)$ de empresas cujo tempo de incentivo foi inferior a 4 anos, um tempo médio de incentivo de 0,9 (DP=1,91) e variação de 0 a 12 anos. Cerca de $25 \%$ das empresas tiveram mais de 1 ano de incentivo. Considerando a taxa unitária do nível de tributação, observe-se uma considerável predominância $(90,7 \%)$ de empresas com nível de tributação oscilando de 0 a 50\%; uma taxa unitária média de tributação de $0,32(\mathrm{DP}=0,81)$ e 
variação de 0 a 12,85 . Cerca de $25 \%$ das empresas apresentaram taxa unitária inferior a 0,08; $50 \%$ apresentaram taxa inferior a 0,20 e $25 \%$ taxa superior a 0,32. Para a variável taxa unitária de crescimento de vendas, observe-se uma predominância de empresas com taxa unitária média de crescimento de $0,36(\mathrm{DP}=1,28)$ e variação de $-1,82$ a 16,18 . Cerca de $25 \%$ das empresas apresentaram taxa unitária inferior a 0,06; 50\% apresentaram taxa inferior a 0,16 e $25 \%$ taxa superior a 0,27 .

O exame dos dados contidos na Tabela 3 evidencia, para as empresas sem incentivo fiscal (n=419), uma sutil predominância de organizações com menos de 7 anos de tempo de operação $(50,3 \%)$; um tempo médio de operação 7,28 (DP = 4,35) e variação de 0 a 13 anos. Cerca de 25\% das empresas operaram menos de 3 anos; $50 \%$ operaram menos de 7 anos e 25\% operaram mais de 11 anos. Considerando a taxa unitária do nível de tributação, observe-se uma considerável predominância $(92,2 \%)$ de empresas com nível de tributação oscilando de 0 a 50\%; uma taxa unitária média de tributação de $0,30(\mathrm{DP}=0,88)$ e variação de 0 a 12,85 . Cerca de $25 \%$ das empresas apresentaram taxa unitária inferior a 0,$05 ; 50 \%$ apresentaram taxa inferior a 0,17 e 25\% taxa superior a 0,30. Para a variável taxa unitária de crescimento de vendas, observe-se uma predominância de empresas com taxa unitária média de crescimento de $0,39(\mathrm{DP}=1,50)$ e variação de $-1,82$ a 16,18. Cerca de $25 \%$ das empresas apresentaram taxa unitária inferior a 0,$03 ; 50 \%$ apresentaram taxa inferior a 0,15 e $25 \%$ taxa superior a 0,28 .

O exame dos dados contidos na Tabela 3 evidencia, para as empresas com incentivo fiscal $(\mathrm{n}=171)$, uma predominância de organizações com mais de 7 anos de tempo de operação $(67,3 \%)$; um tempo médio de operação 9,46 (DP = 3,59) e variação de 2 a 13 anos. Cerca de $25 \%$ das empresas operaram menos de 6 anos; $50 \%$ operaram mais de 11 anos e 25\% operaram mais de 13 anos. Para a variável tempo de incentivo fiscal observa-se uma predominância $(68,4 \%)$ de empresas cujo tempo de incentivo foi inferior a 4 anos, um tempo médio de incentivo de 3,1 ( $\mathrm{DP}=2,40)$ e variação de 1 a 12 anos. Cerca de $25 \%$ das empresas tiveram menos de 1 ano de incentivo, 50\% tiveram menos de 2 anos de incentivo e $25 \%$ tiveram mais de 5 anos de incentivo. Considerando a taxa unitária do nível de tributação, observe-se uma considerável predominância $(87,3 \%)$ de empresas com nível de tributação oscilando de 0 a 50\% ; uma taxa unitária média de tributação de $0,37(\mathrm{DP}=0,61)$ e variação de 0 a 4,90. Cerca de $25 \%$ das empresas apresentaram taxa unitária inferior a 0,$15 ; 50 \%$ apresentaram taxa inferior a 0,25 e $25 \%$ taxa superior a 0,34 . Para a variável taxa unitária do 
crescimento das vendas, observe-se uma considerável predominância $(89,9 \%)$ de empresas com taxa unitária média de crescimento oscilando de 0 a 100\%; uma taxa unitária média de crescimento de $0,28(\mathrm{DP}=0,64)$ e variação de $-0,77$ a 5,33 . Cerca de $25 \%$ das empresas apresentaram taxa unitária inferior a 0,$11 ; 50 \%$ apresentaram taxa inferior a 0,17 e $25 \%$ taxa superior a 0,26 .

\section{Quantifications}

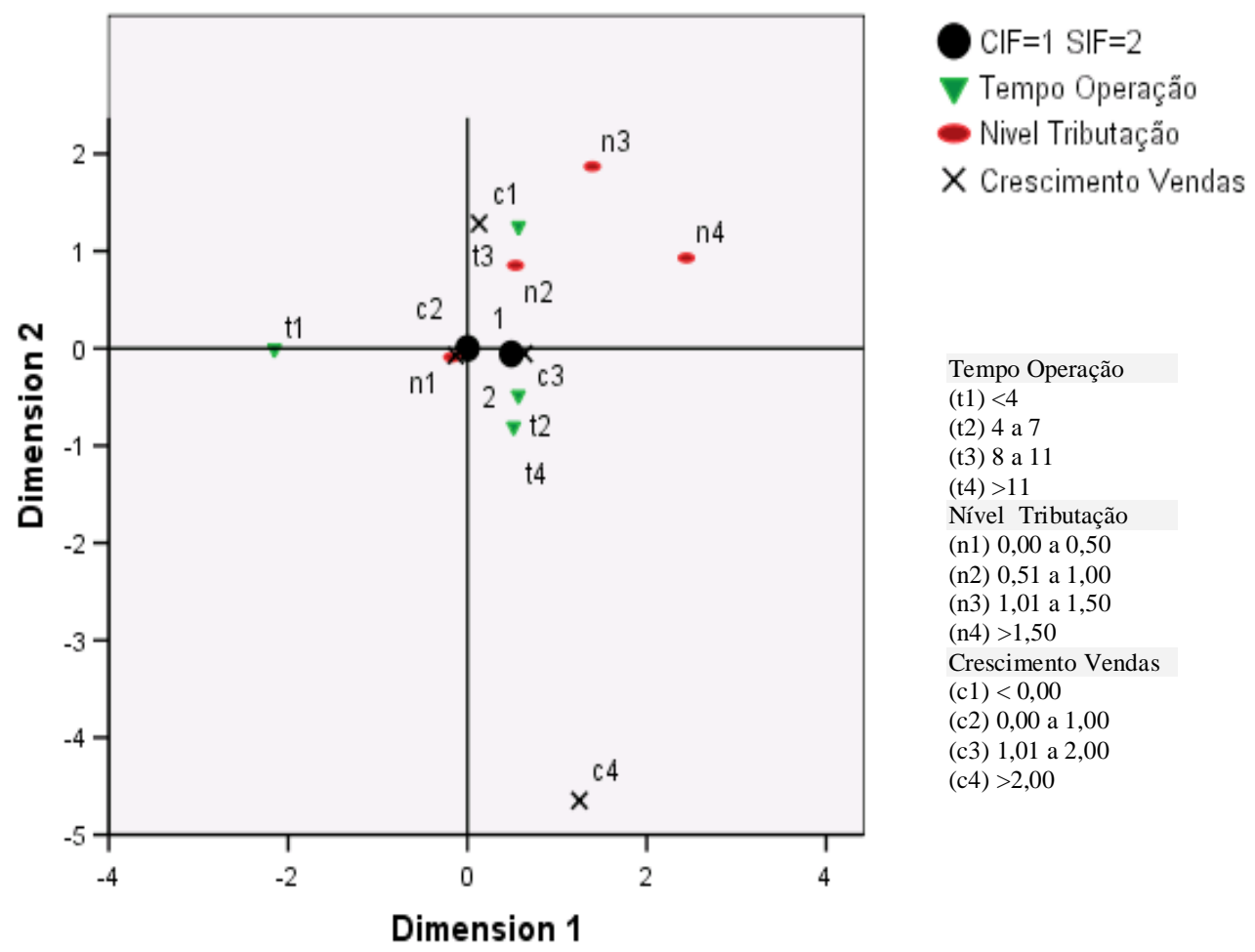

Figura 24 - Mapa perceptual das variáveis incentivo fiscal, tempo de operação, nível de tributação e crescimento de vendas: análise de homogeneidade (HOMALS)

O exame do mapa perceptual contido na Figura 24 sugere que um nível de tributação superior a 100\% não parece estar associado à incentivação fiscal, enquanto níveis de tributação inferior a 50\% parecem estar fortemente associados com a ausência de incentivos fiscais.

O mapa, também, sugere que o crescimento negativo das empresas não parece estar associado à incentivação fiscal. Um crescimento entre 0 e $100 \%$ parece estar associado com a ausência 
de incentivos fiscais. Um nível de crescimento entre 100 e $200 \%$ parece fortemente associado à presença de incentivos fiscais. Crescimento superior a 200\% não parece estar associado à incentivação fiscal.

Observe-se, também, que um tempo de operação inferior a 4 anos parece não estar associado à incentivação fiscal. Um tempo de operação entre 4 e 7 anos ou acima de 11 anos parecem estar relacionados com a presença de incentivos fiscais, o que sugere associação entre tempo de operação e incentivo fiscal.

A Figura 25 exibe os Error Bar para as médias das variáveis Tempo de Operação, Taxa Unitária do Nível de Tributação e Taxa Unitária de Crescimento de Vendas para as empresas com incentivo fiscal.

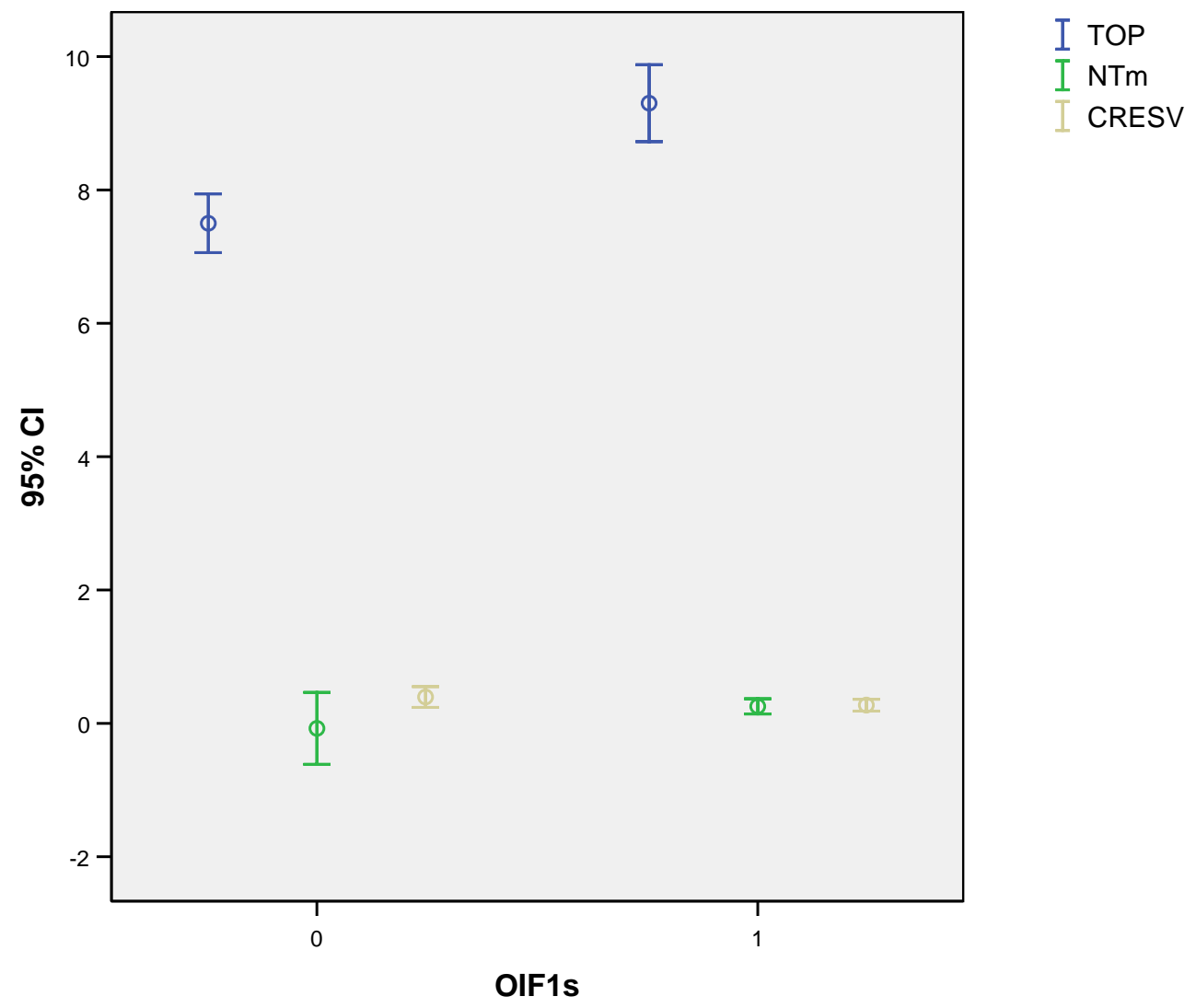

Figura 25 - Error Bar de médias das variáveis TOP, NT $_{m}$ e CRESV sem e com incentivo fiscal

O exame da Figura 25 sugere diferença no tempo médio de operação de empresas com e sem incentivo, sugerindo que empresas com incentivo tendem a apresentar um maior tempo médio de operação, tal resultado é corroborado pelo mapa perceptual contido na Figura 24 e pelo 
teste U de Mann-Whitney exibido na Tabela 3. Oportuno observar que, na Figura 25, não é possível identificar associação entre a obtenção de incentivos fiscais e nível de tributação ou crescimento das vendas.

A Tabela 4 evidencia o total de empresas sem e com incentivos fiscais em cada ano, no período de 1996 a 2007. É relevante destacar o fato de que o percentual do número de empresas com incentivos fiscais decresceu a cada ano no período de 1996 (17\%) a 2007 (8\%). Conseqüentemente, o percentual do número de empresas sem incentivos fiscais aumentou a cada ano no período abrangido. Oportuno observar que, no período, o numero médio anual de empresas não incentivadas foi de 332 contra 40 incentivadas. Observe-se, ainda, que a taxa média de crescimento anual no período avaliado para as empresas sem incentivo foi de $0,98 \%$ enquanto a referida taxa para as empresas com incentivo foi de $-5,4 \%$ (a cada ano observou-se uma redução média de 5,4\% do contingente de empresas incentivadas).

Tabela 4 - Número anual de empresas sem e com incentivos fiscais no período de 1996 a 2007

\begin{tabular}{cccccccc}
\hline Ano & $\begin{array}{c}\text { sem } \\
\text { incentivo } \\
\text { fiscal }\end{array}$ & $\%$ & $\begin{array}{c}\text { Taxa de } \\
\text { crescimento }\end{array}$ & $\begin{array}{c}\text { com } \\
\text { incentivo } \\
\text { fiscal }\end{array}$ & \% & $\begin{array}{c}\text { Taxa de } \\
\text { crescimento }\end{array}$ & Total \\
\hline 1996 & 237 & 82,9 & & 49 & 17,1 & & 286 \\
1997 & 289 & 83,0 & 0,12 & 59 & 17,0 & $-0,58$ & 348 \\
1998 & 355 & 83,9 & 1,08 & 68 & 16,1 & $-5,29$ & 423 \\
1999 & 370 & 87,7 & 4,53 & 52 & 12,3 & $-23,60$ & 422 \\
2000 & 361 & 89,6 & 2,17 & 42 & 10,4 & $-15,45$ & 403 \\
2001 & 339 & 89,7 & 0,11 & 39 & 10,3 & $-0,96$ & 378 \\
2002 & 336 & 91,6 & 2,12 & 31 & 8,4 & $-18,45$ & 367 \\
2003 & 312 & 90,2 & $-1,53$ & 34 & 9,8 & 16,67 & 346 \\
2004 & 324 & 92,8 & 2,88 & 25 & 7,2 & $-26,53$ & 349 \\
2005 & 315 & 90,5 & $-2,48$ & 33 & 9,5 & 31,94 & 348 \\
2006 & 330 & 91,4 & 0,99 & 31 & 8,6 & $-9,47$ & 361 \\
2007 & 328 & 92,1 & 0,77 & 28 & 7,9 & $-8,14$ & 356 \\
\hline MEDIA & 332 & 89,32 & 0,98 & 40 & 11,2 & $-5,44$ & 372 \\
\hline
\end{tabular}

A Figura 26 apresenta a evolução do crescimento percentual do número de empresas que não são beneficiadas pelo incentivo fiscal e a redução do crescimento percentual do número de empresas que são beneficiadas pelo incentivo fiscal. 


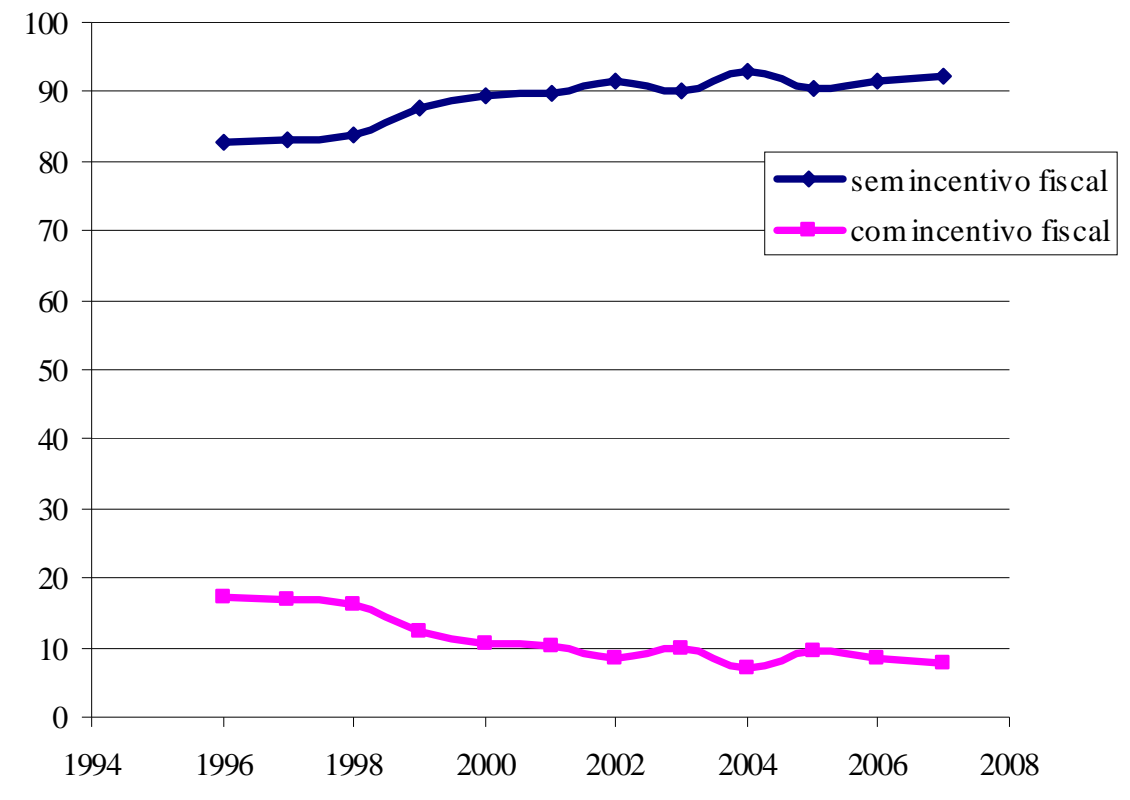

Figura 26 - Percentual anual do número de empresas sem e com incentivos fiscais no período de 1996 a 2007

\subsection{Análise transversal - abordagem tradicional}

Para investigar o problema de pesquisa alvo deste estudo, necessário se fez a descrição das variáveis utilizadas na composição de cada indicador, assim, as Tabelas 5 e 6 relatam as distribuições e as medidas resumo dos indicadores de incentivo fiscal, proporção anual de incentivo fiscal (PAIF), valor médio de incentivo fiscal (VMIF), estrutura de capital (LER, DER e DCR) e rentabilidade (ROA e ROE), respectivamente. As Figuras de 27 a 29 exibem Box Plots para as variáveis nos grupos em estudo. 
Tabela 5 - Distribuição das variáveis PAIF e VMIF no conjunto das empresas com incentivo fiscal

\begin{tabular}{|c|c|c|}
\hline PAIF & Freq & $\%$ \\
\hline$(1)<0,25$ & 117 & 68,4 \\
\hline (2) 0,25 a 0,49 & 37 & 21,6 \\
\hline (3) 0,50 a 0,75 & 13 & 7,6 \\
\hline (4) $>0,75$ & 4 & 2,3 \\
\hline Media \pm DP & $0,24 \pm 0,18$ & \\
\hline Mediana(Q1-Q3) & $0,15(0,08-0,38)$ & \\
\hline Min-Max & $0,08-0,92$ & \\
\hline \multicolumn{3}{|c|}{ VMIF (x R\$ 1.000) } \\
\hline (1) $<250$ & 80 & 46,8 \\
\hline (2) 250 a 499 & 12 & 7,0 \\
\hline (3) 500 a 750 & 12 & 7,0 \\
\hline$(4)>750$ & 67 & 39,2 \\
\hline Média \pm DP & $4805,43 \pm 13176,61$ & \\
\hline Mediana(Q1-Q3) & $305,84(59,76-2966,85)$ & \\
\hline Min-Max & $0,72-91526,46$ & \\
\hline
\end{tabular}

O exame dos dados contidos na Tabela 5 evidencia, para as empresas com incentivo fiscal ( $\mathrm{n}=171)$, uma predominância de organizações com menos de 0,25 de proporção anual de incentivos fiscais $(68,4 \%)$; uma proporção anual média de $0,24(\mathrm{DP}=0,18)$ no período e variação de 0,08 a 0,92. Cerca de $25 \%$ das empresas têm uma proporção anual de incentivos fiscais menor de 0,15 no período; $50 \%$ têm uma proporção maior de 0,15 e 25\% têm uma proporção maior de 0,38 no período. Para a variável valor médio de incentivos fiscais, observe-se uma acentuada predominância $(46,8 \%)$ de empresas com valor de incentivo inferior a 250 mil, um valor médio de incentivo de 4.805,43 milhões ( $\mathrm{DP}=13.176,61)$ e variação de 0,72 a 91.526,46 milhões . Cerca de $25 \%$ das empresas tiveram um valor médio de incentivo menor que 59,76 mil;50\% tiveram um valor médio de 305,84 mil e 25\% tiveram um valor maior que $2.966,85$ milhões. 
Tabela 6 - Distribuição das variáveis $\mathrm{ROA}_{m}, \mathrm{ROE}_{\mathrm{m}}, \mathrm{LER}_{\mathrm{m}}, \mathrm{DER}_{\mathrm{m}}$ e $\mathrm{DCR}_{\mathrm{m}}$ no conjunto das empresas e nos grupos de empresas sem e com incentivo fiscal

\begin{tabular}{|c|c|c|c|c|}
\hline VARIAVEL & $\begin{array}{c}\text { GLOBAL } \\
(\mathbf{n}=590)\end{array}$ & $\begin{array}{c}\text { Sem incentivo } \\
(n=419)\end{array}$ & $\begin{array}{c}\text { Com incentivo } \\
(n=171)\end{array}$ & $\mathbf{p}^{\mathbf{a}}$ \\
\hline \multicolumn{5}{|l|}{$\mathbf{R O A}_{\mathrm{m}}$} \\
\hline Media \pm DP & $-1,92 \pm 38,39$ & $-2,73 \pm 45,71$ & $0,02 \pm 0,13$ & \multirow{3}{*}{$<0,001$} \\
\hline Mediana(Q1-Q3) & $0,02(-0,04-0,05)$ & $0,00(-0,07-0,04)$ & $0,04(0,00-0,07)$ & \\
\hline Min-Max & $-917,67-36,14$ & $-917,67-36,14$ & $-1,22-0,24$ & \\
\hline \multicolumn{5}{|l|}{$\mathbf{R O E}_{\mathrm{m}}$} \\
\hline Media \pm DP & $1,46 \pm 39,50$ & $2,04 \pm 47,03$ & $0,06 \pm 0,95$ & \multirow{3}{*}{0,001} \\
\hline Mediana(Q1-Q3) & $0,06(-0,05-0,14)$ & $0,05(-0,10-0,14)$ & $0,09(0,03-0,15)$ & \\
\hline Min-Max & $-17,34-950,28$ & $-17,34-950,28$ & $-3,91-10,23$ & \\
\hline \multicolumn{5}{|l|}{$\mathbf{L E R}_{\mathrm{m}}$} \\
\hline Media \pm DP & $6,18 \pm 53,58$ & $7,55 \pm 63,60$ & $2,91 \pm 7,31$ & \multirow{3}{*}{0,491} \\
\hline Mediana(Q1-Q3) & $1,21(0,46-2,62)$ & $1,29(0,39-3,00)$ & $1,05(0,54-2,13)$ & \\
\hline Min-Max & $-346,13-1128,77$ & $-346,13-1128,77$ & $-3,34-63,93$ & \\
\hline \multicolumn{5}{|l|}{ DER $_{\mathrm{m}}$} \\
\hline Media \pm DP & $0,96 \pm 9,90$ & $0,86 \pm 11,50$ & $1,22 \pm 4,05$ & \multirow{3}{*}{0,200} \\
\hline Mediana(Q1-Q3) & $0,44(0,09-0,98)$ & $0,43(0,05-0,98)$ & $0,44(0,15-1,01)$ & \\
\hline Min-Max & $-205,89-70,81$ & $-205,89-70,81$ & $-2,27-45,43$ & \\
\hline \multicolumn{5}{|l|}{$\mathbf{D C R}_{\mathrm{m}}$} \\
\hline Media \pm DP & $0,86 \pm 18,05$ & $1,10 \pm 21,50$ & $0,27 \pm 0,31$ & \multirow{3}{*}{0,953} \\
\hline Mediana(Q1-Q3) & $0,28(0,08-0,46)$ & $0,29(0,07-0,47)$ & $0,26(0,11-0,45)$ & \\
\hline Min-Max & $-124,00-414,77$ & $-124,00-414,77$ & $-1,84-1,41$ & \\
\hline
\end{tabular}

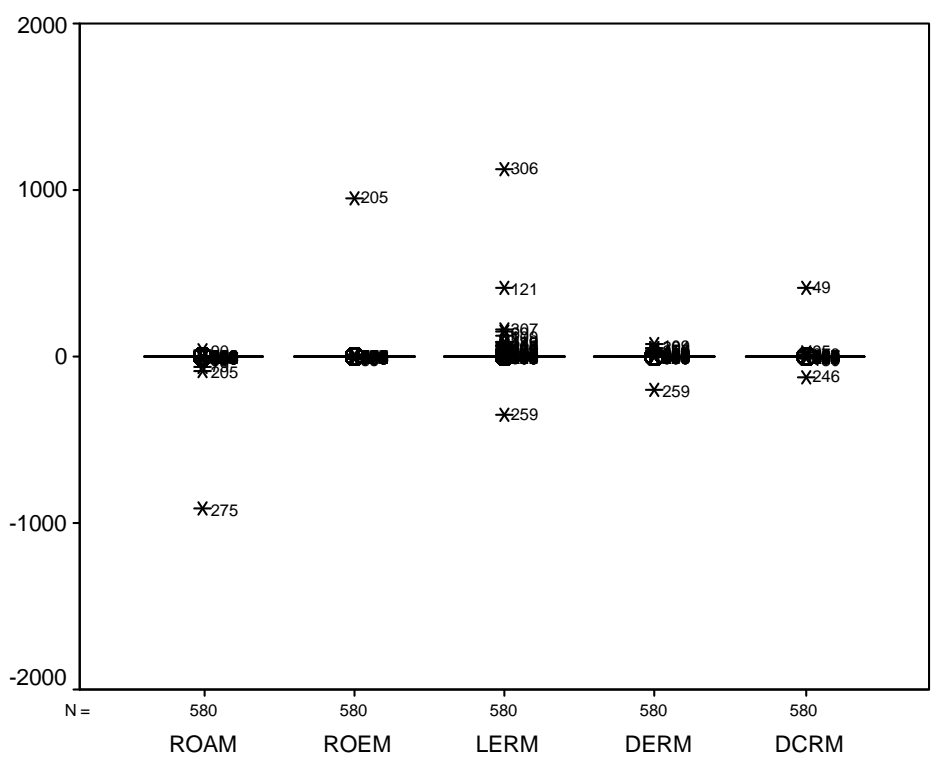

Figura 27 - Box plot para as variáveis ROAm, ROEm, LERm, DERm e DCRm para o conjunto das empresas

O exame dos dados contidos na Tabela 6 e na Figura 27 evidencia, para o conjunto de empresas $(n=590)$, um $\mathrm{ROA}_{\mathrm{m}}$ na média de -1,92 (DP = 38,39) e variação de -917,67 a 36,14. Cerca de $25 \%$ das empresas tiveram um $\mathrm{ROA}_{\mathrm{m}}$ menor que $-0,04 ; 50 \%$ tiveram um $\mathrm{ROA}_{\mathrm{m}}$ menor que 0,02 e $25 \%$ tiveram um $\mathrm{ROA}_{\mathrm{m}}$ maior que 0,05 . Para a variável $\mathrm{ROE}_{\mathrm{m}}$, observe-se 
uma média de $1,46(\mathrm{DP}=39,50)$ e variação de $-17,34$ a 950,28. Cerca de $25 \%$ das empresas tiveram um $\mathrm{ROE}_{\mathrm{m}}$ menor do que $-0,05 ; 50 \%$ um $\mathrm{ROE}_{\mathrm{m}}$ menor do que 0,06 e $25 \%$ das empresas tiveram um $\mathrm{ROE}_{\mathrm{m}}$ maior do que 0,14. Considerando a variável $\mathrm{LER}_{\mathrm{m}}$, observe-se uma média de $6,18(\mathrm{DP}=53,58)$ e variação de $-346,13$ a $1.128,77$. Cerca de $25 \%$ das empresas apresentaram um $\mathrm{LER}_{\mathrm{m}}$ inferior a 0,46; 50\% apresentaram $\mathrm{LER}_{\mathrm{m}}$ inferior a $1,21 \mathrm{e}$ 25\% LERm superior a 2,62. Para a variável $\mathrm{DER}_{\mathrm{m}}$, observe-se uma média de 0,96 (DP = 9,90) e variação de $-205,89$ a 70,81. Cerca de $25 \%$ das empresas apresentaram DER $_{m}$ inferior a 0,$09 ; 50 \%$ apresentaram $\mathrm{DER}_{\mathrm{m}}$ inferior a 0,44 e $25 \% \mathrm{DER}_{\mathrm{m}}$ superior a 0,98 . Para a variável $\mathrm{DCR}_{\mathrm{m}}$, observe-se uma média de $0,86(\mathrm{DP}=18,05)$ e variação de $-124,00$ a 414,77. Cerca de $25 \%$ das empresas apresentaram $\mathrm{DCR}_{\mathrm{m}}$ inferior a 0,$08 ; 50 \%$ apresentaram $\mathrm{DCR}_{\mathrm{m}}$ inferior a 0,28 e $25 \%$ apresentaram $\mathrm{DCR}_{\mathrm{m}}$ superior a 0,46 .

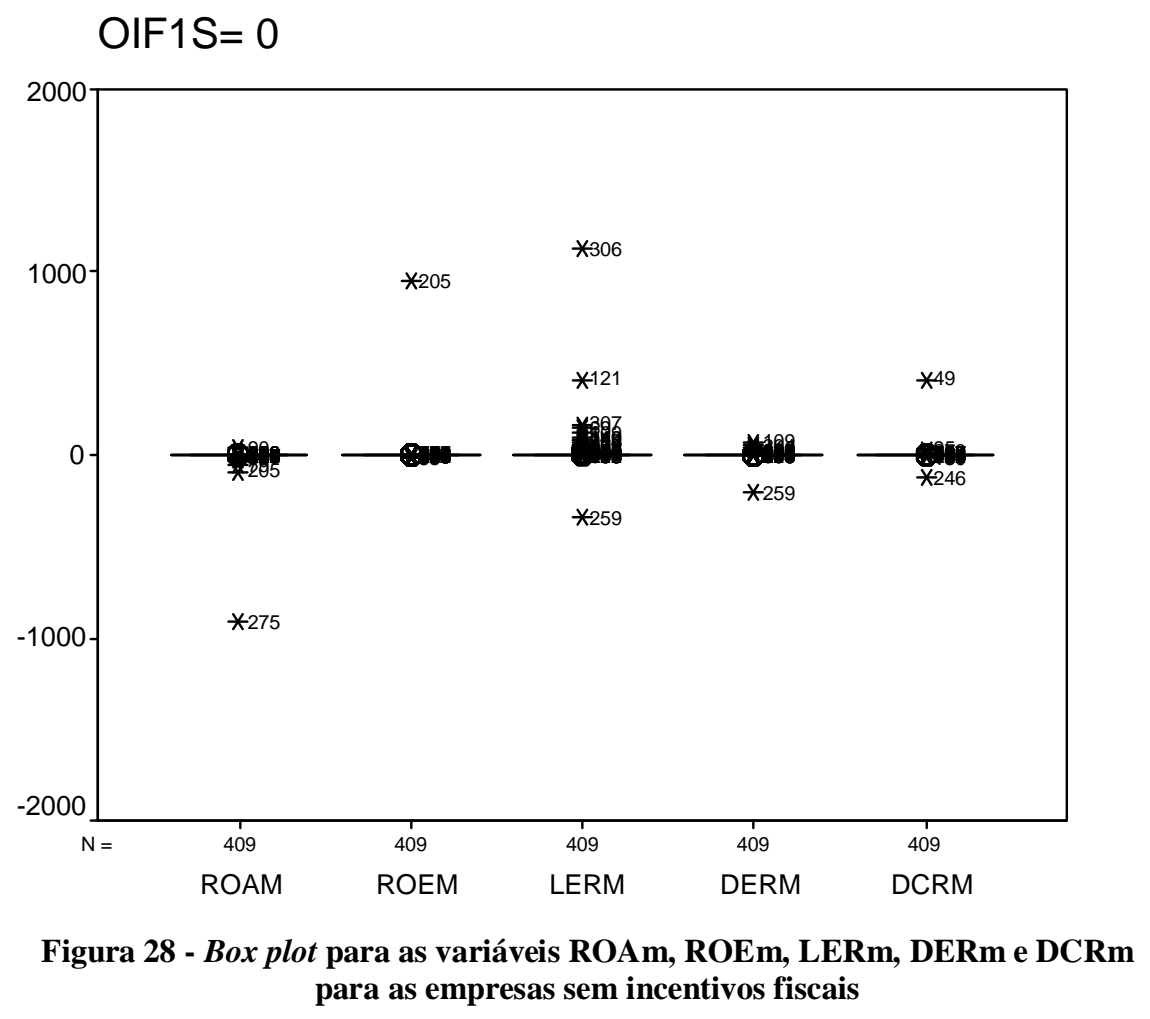

O exame dos dados contidos na Tabela 6 e na Figura 24 evidencia, para as empresas sem incentivo fiscal $(n=419)$, um $\mathrm{ROA}_{\mathrm{m}}$ médio de $-2,73(\mathrm{DP}=45,71)$ e variação de $-917,67$ a 36,14. Cerca de $25 \%$ das empresas apresentaram um $\mathrm{ROA}_{m}$ menor do que $-0,07 ; 50 \%$ apresentaram um $\mathrm{ROA}_{\mathrm{m}}$ menor do que 0,00 e $25 \%$ apresentaram um $\mathrm{ROA}_{\mathrm{m}}$ maior do que 0,04. Para a variável $\mathrm{ROE}_{\mathrm{m}}$, observe-se uma média de 2,04 ( $\left.\mathrm{DP}=47,03\right)$ e variação de $-17,34$ a 
950,28. Cerca de $25 \%$ das empresas tiveram um $\mathrm{ROE}_{\mathrm{m}}$ inferior a $-0,10 ; 50 \%$ tiveram um $\mathrm{ROE}_{\mathrm{m}}$ inferior a 0,05 e $25 \%$ tiveram um $\mathrm{ROE}_{\mathrm{m}}$ superior a 0,14 . Considerando a variável $\mathrm{LER}_{\mathrm{m}}$, observe-se uma média de 7,55 (DP=63,60) e variação de $-346,13$ a 1.128,77. Cerca de $25 \%$ das empresas apresentaram $\mathrm{LER}_{\mathrm{m}}$ inferior a 0,$39 ; 50 \%$ apresentaram $\mathrm{LER}_{\mathrm{m}}$ inferior a 1,29 e $25 \%$ LER $_{m}$ superior a 3,00. Para a variável DER, observe-se uma média de 0,86 $(\mathrm{DP}=11,50)$ e variação de $-205,89$ a 70,81. Cerca de $25 \%$ das empresas apresentaram $\mathrm{DER}_{\mathrm{m}}$ inferior a 0,$05 ; 50 \%$ apresentaram $\mathrm{DER}_{\mathrm{m}}$ inferior a 0,43 e $25 \% \mathrm{DER}_{\mathrm{m}}$ superior a 0,98 . Para a variável DCR, observe-se uma média de 1,10 (DP=21,50) e variação de -124,00 a 414,77. Cerca de $25 \%$ das empresas apresentaram $\mathrm{DCR}_{\mathrm{m}}$ inferior a 0,$07 ; 50 \%$ apresentaram $\mathrm{DCR}_{\mathrm{m}}$ inferior a 0,29 e $25 \% \mathrm{DCR}_{\mathrm{m}}$ superior a 0,47 .

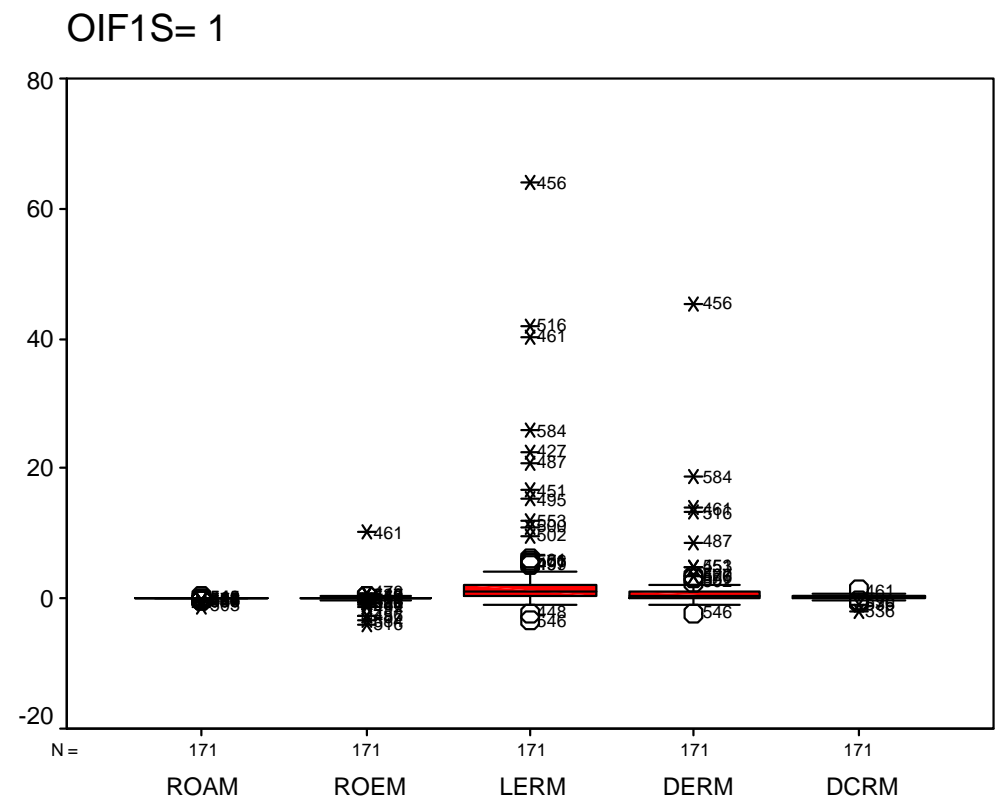

Figura 29 - Box plot para as variáveis ROAm, ROEm, LERm, DERm e DCRm para as empresas com incentivos fiscais

O exame dos dados contidos na Tabela 6 e na Figura 29 evidencia, para as empresas com incentivo fiscal $(n=171)$, um $\mathrm{ROA}_{\mathrm{m}}$ médio de $0,02(\mathrm{DP}=0,13)$ e variação de $-1,22$ a 0,24. Cerca de $25 \%$ das empresas apresentaram um $\mathrm{ROA}_{\mathrm{m}}$ menor do que 0,$00 ; 50 \%$ apresentaram um $\mathrm{ROA}_{\mathrm{m}}$ menor do que 0,04 e $25 \%$ apresentaram um $\mathrm{ROA}_{\mathrm{m}}$ maior do que 0,07 . Para a variável $\mathrm{ROE}_{\mathrm{m}}$, observe-se uma média de $0,06(\mathrm{DP}=0,95)$ e variação de $-3,91$ a 10,23. Cerca de $25 \%$ das empresas tiveram um $\mathrm{ROE}_{\mathrm{m}}$ inferior a 0,$03 ; 50 \%$ tiveram um $\mathrm{ROE}_{\mathrm{m}}$ inferior a 0,09 e $25 \%$ tiveram um $\mathrm{ROE}_{\mathrm{m}}$ superior a 0,15 . Considerando a variável LER $_{\mathrm{m}}$, observe-se uma média de 2,91 (DP=7,31) e variação de $-3,34$ a 63,93. Cerca de $25 \%$ das empresas 
apresentaram $\mathrm{LER}_{\mathrm{m}}$ inferior a 0,$54 ; 50 \%$ apresentaram $\mathrm{LER}_{\mathrm{m}}$ inferior a 1,05 e $25 \% \mathrm{LER}_{\mathrm{m}}$ superior a 2,13. Para a variável $\mathrm{DER}_{\mathrm{m}}$, observe-se uma média de 1,22 $(\mathrm{DP}=4,05)$ e variação de $-2,27$ a 45,43 . Cerca de $25 \%$ das empresas apresentaram $D_{E R}$ inferior a 0,$15 ; 50 \%$ apresentaram $\mathrm{DER}_{\mathrm{m}}$ inferior a 0,44 e $25 \% \mathrm{DER}_{\mathrm{m}}$ superior a 1,01. Para a variável $\mathrm{DCR}_{\mathrm{m}}$, observe-se uma média de 0,27 (DP=0,31) e variação de $-1,84$ a 1,41. Cerca de $25 \%$ das empresas apresentaram $\mathrm{DCR}_{\mathrm{m}}$ inferior a 0,$11 ; 50 \%$ apresentaram $\mathrm{DCR}_{\mathrm{m}}$ inferior a 0,26 ; e $25 \%$ $\mathrm{DCR}_{\mathrm{m}}$ superior a 0,45 .

A Figura 30 exibe o Error Bar dos indicadores da estrutura de capital e da rentabilidade nas empresas sem e com incentivos fiscais.

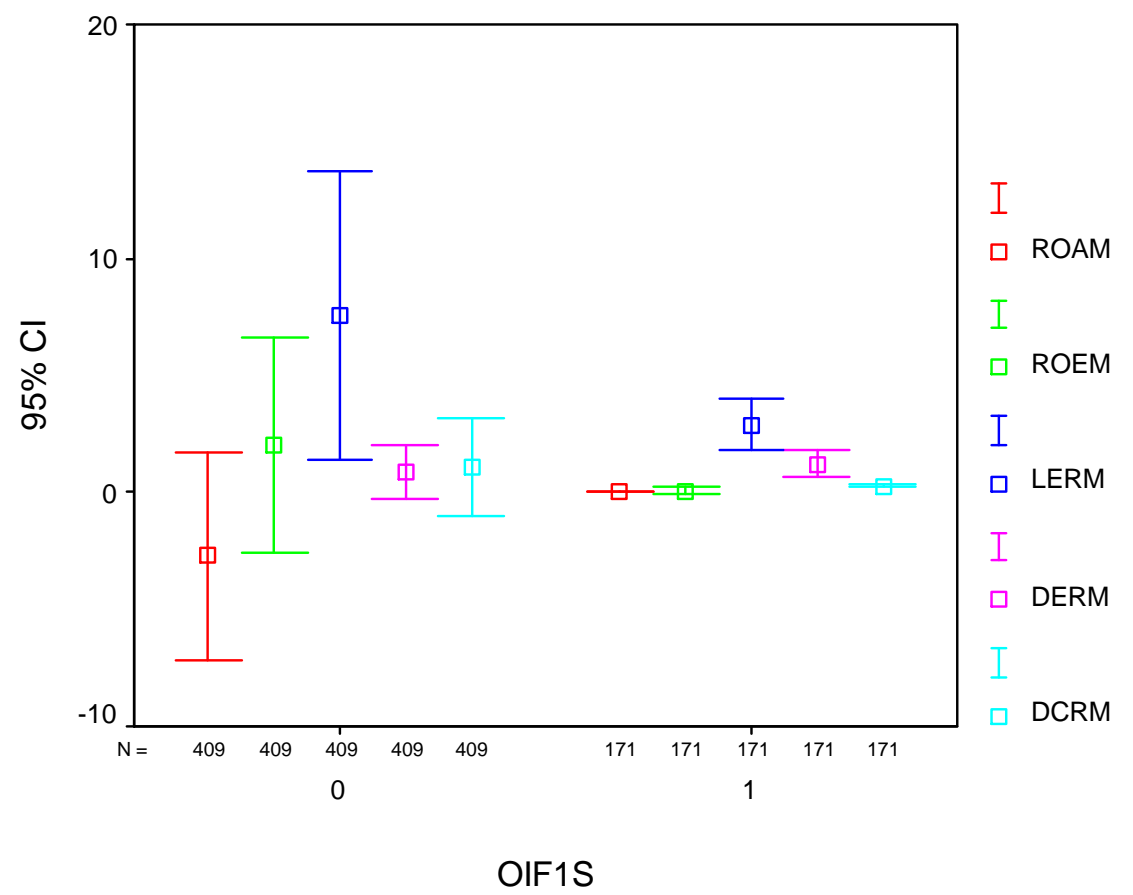

Figura 30- Error Bar de médias das variáveis ROAm, ROEm, LERm, DERm e DCRm em empresas sem e com incentivos fiscais

O exame da Figura 30 não permite aferir julgamento entre os valores médios dos indicadores nos grupos em estudo. 


\subsection{Análise transversal baseada no método GLM Univariate}

O procedimento GLM Univariate proporciona uma análise de variância para múltiplas variáveis dependentes e um fator que divide a população em grupos. Usando o GLM Univariate é possível serem testadas hipóteses nulas sobre os efeitos do fator sobre as médias das variáveis dependentes nos vários grupos de uma distribuição conjunta de variáveis dependentes.

\subsubsection{Modelo GLM Univariate para o estudo do efeito do incentivo fiscal sobre os indicadores de estrutura de capital e rentabilidade}

Neste estudo, foi discutido o efeito da obtenção de incentivo fiscal (OIF) sobre os indicadores de estrutura de capital e rentabilidade, isto é, compararam-se os níveis do ROA, ROE, LER, DER e DCR das empresas sem incentivo fiscal $(\mathrm{OIF}=0)$ com o das empresas com incentivo fiscal $(\mathrm{OIF}=1)$, considerando-se os valores médios dos indicadores para as 590 empresas do estudo. A Figura 31 exibe a estrutura estilizada do modelo.

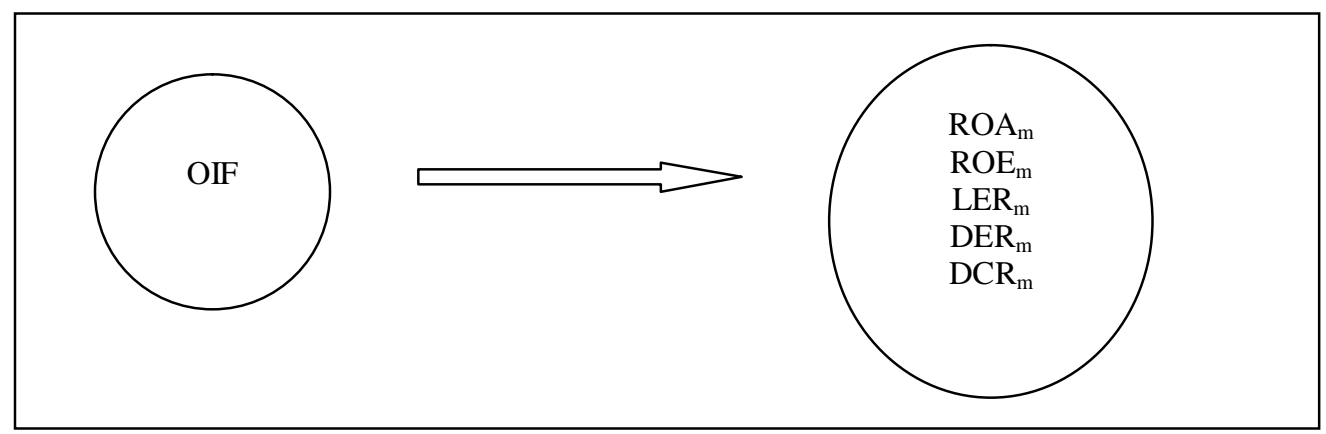

Figura 31 - Incentivos fiscais e desempenho econômico financeiro

Visto que existem mais de 20 observações em cada um dos dois grupos e que esse número de observações supera o número de variáveis dependentes, os tamanhos das amostras devem ser adequados para fornecer um poder estatístico de, no mínimo, $80 \%$ para os testes estatísticos. Oportuno observar que o poder estatístico de um teste de significância é a probabilidade de que o teste estatístico identifique um efeito do tratamento se ele realmente existir. (HAIR et al., 2005). 
A Tabela 7 exibe as estatísticas descritivas ligadas a cada indicador de estrutura de capital e rentabilidade

Tabela 7 - Média e desvio padrão dos indicadores de estrutura de capital e rentabilidade

\begin{tabular}{|c|c|c|c|c|c|c|c|c|c|}
\hline & \multicolumn{9}{|c|}{ OIF1S } \\
\hline & \multicolumn{3}{|c|}{$\mathbf{0}$} & \multicolumn{3}{|c|}{1} & \multicolumn{3}{|c|}{ Total } \\
\hline & Mean & SD & $\mathbf{N}$ & Mean & SD & $\mathbf{N}$ & Mean & SD & $\mathbf{N}$ \\
\hline $\mathrm{ROA}_{\mathrm{m}}$ & $-2,731$ & 45,71 & 409 & 0,016 & 0,133 & 171 & $-1,921$ & 38,39 & 580 \\
\hline $\mathrm{ROE}_{\mathrm{m}}$ & 2,041 & 47,03 & 409 & 0,056 & 0,954 & 171 & 1,456 & 39,50 & 580 \\
\hline $\mathrm{LER}_{\mathrm{m}}$ & 7,547 & 63,60 & 409 & 2,906 & 7,310 & 171 & 6,179 & 53,58 & 580 \\
\hline $\mathrm{DER}_{\mathrm{m}}$ & 0,856 & 11,50 & 409 & 1,223 & 4,052 & 171 & 0,964 & 9,90 & 580 \\
\hline $\mathrm{DCR}_{\mathrm{m}}$ & 1,101 & 21,50 & 409 & 0,272 & 0,307 & 171 & 0,857 & 18,05 & 580 \\
\hline
\end{tabular}

Antes de calcular as estatísticas de teste para diferenças de médias ao longo dos grupos, devese determinar se as medidas dependentes estão, significantemente, correlacionadas. O teste mais utilizado para esse fim é o teste de esfericidade de Bartlett. A Tabela 8 exibe o resultado do teste

Tabela 8 - Teste de esfericidade de Bartlett

\begin{tabular}{lc}
\hline Likelihood Ratio & 0,000 \\
Approx. Chi-Square & $1.639,63$ \\
Df & 14 \\
Sig. & 0,000 \\
\hline Tests the null hypothesis that the residual covariance matrix is proportional to an \\
identify matrix \\
a. Design: Intercept+OIFiS
\end{tabular}

O teste de Bartlett avalia a hipótese nula de que a matriz de covariância residual é proporcional a uma matriz identidade o que equivale a dizer que as variáveis dependentes não estão correlacionadas. Na Tabela 8 , observe-se que $p<0,001$, o que recomenda a rejeição da hipótese nula, isto é, é razoável admitir que as variáveis dependentes estejam correlacionadas. É oportuno observar que, nesse teste, se a hipótese nula não pudesse ser rejeitada e o tamanho da amostra fosse razoavelmente grande, deveria ser reconsiderado o uso da análise multivariada no estudo.

Outra suposição crítica da MANOVA refere-se à homogeneidade univariada de variância de cada variável dependente (Tabela 9) e a dependência coletiva dessas variáveis (Tabela 10) avaliadas testando-se a igualdade das matrizes de variância-covariância. 
Tabela 9 - Teste de Levene da igualdade de variâncias

\begin{tabular}{lcccc}
\hline & F & Df1 & Df2 & Sig \\
$\mathrm{ROA}_{\mathrm{m}}$ & 2,336 & 1 & 578 & 0,127 \\
$\mathrm{ROE}_{\mathrm{m}}$ & 1,505 & 1 & 578 & 0,220 \\
$\mathrm{LER}_{\mathrm{m}}$ & 4,145 & 1 & 578 & 0,042 \\
$\mathrm{DER}_{\mathrm{m}}$ & 0,515 & 1 & 578 & 0,473 \\
$\mathrm{DCR}_{\mathrm{m}}$ & 1,716 & 1 & 578 & 0,191 \\
\hline Tests the null hypothesis that the error variance of the dependent variable is equal across group. \\
a. Design: Intercept+OIF1S
\end{tabular}

De acordo com os dados contidos na Tabela 9, contendo o teste de Levene, somente a variável $\mathrm{LER}_{\mathrm{m}}$ não parece ter variâncias iguais nos grupos em estudo $(p=0,042)$.

Tabela 10 - Teste de igualdade das matrizes de covariância de Box

\begin{tabular}{lr}
\hline Box's M & $5.229,203$ \\
F & 344,510 \\
Df1 & 15 \\
Df2 & 450498 \\
Sig. & 0,000 \\
\hline Tests the null hipothesis that the observed covariance matrices of \\
the dependent variables are equal across groups. \\
\multicolumn{2}{l|}{ a. Design: Intercept+OIF1S }
\end{tabular}

Na Tabela 10, o teste de Box avalia a equivalência geral das matrizes de variância-covariância formada nos grupos. Para este estudo, segundo o resultado do teste, não é razoável admitir a equivalência geral entre as referidas matrizes $(p<0,001)$.

A Tabela 11 exibe quatro testes multivariados da significância de cada efeito. No modelo a análise inclui o intercepto ou "efeito que independe do grupo" sobre o conjunto de variáveis independentes fixados para o estudo. 
Tabela 11 - Testes multivariados

\begin{tabular}{|c|c|c|c|c|c|c|c|c|c|}
\hline \multicolumn{2}{|c|}{ Effect } & Value & $\mathbf{F}$ & $\begin{array}{c}\text { Hypothesis } \\
\text { df }\end{array}$ & $\begin{array}{c}\text { Error } \\
\text { df }\end{array}$ & Sig. & $\begin{array}{c}\text { Eta } \\
\text { Squared }\end{array}$ & $\begin{array}{l}\text { Noncent. } \\
\text { Parameter }\end{array}$ & $\begin{array}{l}\text { Observed } \\
\text { Power }^{\mathrm{a}}\end{array}$ \\
\hline \multirow[t]{4}{*}{ Intercept } & $\begin{array}{l}\text { Pilai's } \\
\text { Trace }\end{array}$ & 0,016 & $1,83^{b}$ & 5,000 & 574,00 & 0,105 & 0,016 & 9,159 & 0,628 \\
\hline & $\begin{array}{l}\text { Wilsk's } \\
\text { Lambda }\end{array}$ & 0,984 & $1,83^{\mathrm{b}}$ & 5,000 & 574,00 & 0,105 & 0,016 & 9,159 & 0,628 \\
\hline & $\begin{array}{l}\text { Hotelling's } \\
\text { Trace }\end{array}$ & 0,016 & $1,83^{\mathrm{b}}$ & 5,000 & 574,00 & 0,105 & 0,016 & 9,159 & 0,628 \\
\hline & $\begin{array}{l}\text { Roy’s } \\
\text { Largest } \\
\text { Root } \\
\end{array}$ & 0,016 & $1,83^{\mathrm{b}}$ & 5,000 & 574,00 & 0,105 & 0,016 & 9,159 & 0,628 \\
\hline \multirow[t]{4}{*}{ OIF1S } & $\begin{array}{l}\text { Pilai's } \\
\text { Trace }\end{array}$ & 0,004 & $0,515^{b}$ & 5,000 & 574,00 & 0,765 & 0,004 & 2,573 & 0,192 \\
\hline & $\begin{array}{l}\text { Wilsk's } \\
\text { Lambda }\end{array}$ & 0,996 & $0,515^{\mathrm{b}}$ & 5,000 & 574,00 & 0,765 & 0,004 & 2,573 & 0,192 \\
\hline & $\begin{array}{l}\text { Hotelling's } \\
\text { Trace }\end{array}$ & 0,004 & $0,515^{\mathrm{b}}$ & 5,000 & 574,00 & 0,765 & 0,004 & 2,573 & 0,192 \\
\hline & $\begin{array}{l}\text { Roy's } \\
\text { Largest } \\
\text { Root }\end{array}$ & 0,004 & $0,515^{\mathrm{b}}$ & 5,000 & 574,00 & 0,765 & 0,004 & 2,573 & 0,192 \\
\hline
\end{tabular}

a. Computed using alpha $=0,05$

b. Exact statistic

c. Design: Intercept+OIF1S

O exame dos resultados exibidos na Tabela 11 relacionados com o efeito OIF1s (incentivo fiscal) revela que para qualquer uma das medidas de diferenças multivariadas (Pillai’s Trace, Wilk's Lambda ...) a combinação das variáveis dependentes não variou nos dois grupos considerados, isto é, o incentivo fiscal não apresenta efeito estatisticamente significativo sobre a combinação das variáveis dependentes (para todos os testes $p=0,765$ ). É oportuno observar que dos quatro testes contidos na tabela, o Wilk's Lambda é conveniente devido a sua ligação com o critério de razão de verossimilhança; todavia, para muitas situações práticas o Pillai's Trace pode ser mais robusto e poderoso quando comparado com os outros testes. Outra questão importante sobre os resultados da tabela é o poder estatístico dos testes, que foi inferior a 0,80. De acordo com Hair et al. (2005), o aumento do tamanho da amostra em cada grupo tende a aumentar o poder dos testes até o momento em que os grupos atingem aproximadamente 150, quando o poder começa a decair. Daí a necessidade de adoção de tamanho de amostras que considerem o nível alfa e o nível beta do teste ligado ao desfecho alvo. A Tabela 12 exibe testes de efeitos entre elementos sobre cada uma das variáveis dependentes do estudo sendo que na primeira coluna são exibidas as fontes dos referidos efeitos no modelo. 
Tabela 12 - Testes de efeitos entre elementos do modelo

\begin{tabular}{|c|c|c|c|c|c|c|c|c|c|}
\hline Source & $\begin{array}{c}\text { Dependent } \\
\text { Variable }\end{array}$ & $\begin{array}{l}\text { Type III Sum } \\
\text { of Squares }\end{array}$ & df & $\begin{array}{c}\text { Mean } \\
\text { Square } \\
\end{array}$ & $\mathbf{F}$ & Sig. & $\begin{array}{c}\text { Eta } \\
\text { Squared } \\
\end{array}$ & $\begin{array}{c}\text { Noncent. } \\
\text { Parameter }\end{array}$ & $\begin{array}{c}\text { Observed } \\
\text { Power }^{\mathrm{a}}\end{array}$ \\
\hline \multirow{5}{*}{$\begin{array}{c}\text { Corrected } \\
\text { Model }\end{array}$} & ROAm & $910,02^{\mathrm{b}}$ & 1 & 910,02 & 0,617 & 0,433 & 0,001 & 0,617 & 0,123 \\
\hline & ROEm & $475,28^{b}$ & 1 & 475,28 & 0,304 & 0,581 & 0,001 & 0,304 & 0,085 \\
\hline & LERm & $2596,42^{c}$ & 1 & 2596,42 & 0,904 & 0,342 & 0,002 & 0,904 & 0,158 \\
\hline & DERm & $16,20^{\mathrm{d}}$ & 1 & 16,20 & 0,165 & 0,685 & 0,000 & 0,165 & 0,069 \\
\hline & DCRm & $83,01^{\mathrm{d}}$ & 1 & 83,01 & 0,254 & 0,614 & 0,000 & 0,254 & 0,080 \\
\hline \multirow[t]{5}{*}{ Intercept } & ROAm & 888,99 & 1 & 888,99 & 0,603 & 0,438 & 0,001 & 0,603 & 0,121 \\
\hline & ROEm & 530,88 & 1 & 530,88 & 0,340 & 0,560 & 0,001 & 0,340 & 0,090 \\
\hline & LERm & 13178,13 & 1 & 13178,1 & 4,590 & 0,033 & 0,008 & 4,590 & 0,571 \\
\hline & DERm & 521,39 & 1 & 521,39 & 5,308 & 0,022 & 0,009 & 5,308 & 0,633 \\
\hline & DCRm & 227,62 & 1 & 227,62 & 0,698 & 0,404 & 0,001 & 0,698 & 0,133 \\
\hline \multirow[t]{5}{*}{ OIF1S } & ROAm & 910,02 & 1 & 910,02 & 0,617 & 0,433 & 0,001 & 0,617 & 0,123 \\
\hline & ROEm & 475,28 & 1 & 475,28 & 0,304 & 0,581 & 0,001 & 0,304 & 0,085 \\
\hline & LERm & 2596,42 & 1 & 2596,42 & 0,904 & 0,342 & 0,002 & 0,904 & 0,158 \\
\hline & DERm & 16,20 & 1 & 16,20 & 0,165 & 0,685 & 0,000 & 0,165 & 0,069 \\
\hline & $\mathrm{DCRm}$ & 83,01 & 1 & 83,01 & 0,254 & 0,614 & 0,000 & 0,254 & 0,080 \\
\hline \multirow[t]{5}{*}{ Error } & ROAm & 852561,09 & 578 & 1475,01 & & & & & \\
\hline & ROEm & 902759,62 & 578 & 1561,86 & & & & & \\
\hline & LERm & 1659631,94 & 578 & 2871,33 & & & & & \\
\hline & DERm & 56779,44 & 578 & 98,23 & & & & & \\
\hline & DCRm & 188615,44 & 578 & 326,324 & & & & & \\
\hline \multirow[t]{5}{*}{ Total } & ROAm & 855611,99 & 580 & & & & & & \\
\hline & ROEm & 904465,23 & 580 & & & & & & \\
\hline & LERm & 1684373,07 & 580 & & & & & & \\
\hline & DERm & 57335,17 & 580 & & & & & & \\
\hline & DCRm & 189124,64 & 580 & & & & & & \\
\hline \multirow{5}{*}{$\begin{array}{c}\text { Corrected } \\
\text { Total }\end{array}$} & ROAm & 853471,11 & 579 & & & & & & \\
\hline & ROEm & 903234,90 & 579 & & & & & & \\
\hline & LERm & 1662228,37 & 579 & & & & & & \\
\hline & DERm & 56795,65 & 579 & & & & & & \\
\hline & DCRm & 188698,46 & 579 & & & & & & \\
\hline \multicolumn{10}{|c|}{ a. Computed using alpha $=0,05$} \\
\hline \multicolumn{10}{|c|}{ b. $R$ Squared $=0,001$ (Adjusted $R$ Squared $=-0,001)$} \\
\hline \multicolumn{10}{|c|}{ c. $R$ Squared $=0,002$ (Adjusted $R$ Squared $=0,000)$} \\
\hline \multicolumn{10}{|c|}{ d. $R$ Squared $=0,000$ (Adjusted $R$ Squared $=-0,001)$} \\
\hline
\end{tabular}

O exame dos dados contidos na Tabela 12 evidencia ausência de efeito estatisticamente significativo da variável OIF sobre qualquer das variáveis dependentes do estudo (todos os "Sig." associados ao efeito OIF são superiores a 0,05). A significância do efeito do elemento "Intercept" sobre as variáveis LER e DER sugere que pode existir um efeito independente de OIF afetando o valor de LER e DER. Como pode ser observado no rodapé da tabela, o $R$ square associado à regressão utilizada na geração das estimativas (regressão da combinação 
das variáveis dependentes sobre a variável OIF) tem um valor extremamente baixo significando que o modelo não é explicativo. Ademais, em função de que a estatística $\mathrm{F}$ não apresentou significância (Sig.>0,05) é recomendável o abandono do referido modelo. O resultado observado na Tabela 11 já tinha sugerido tal abandono.

Apenas ilustrativamente, exibe-se, na Tabela 13, a regressão de cada variável dependente sobre a variável OIF. Oportuno lembrar que já foi exibido na Tabela 12 que nenhum dos ajustes tem significância estatística.

Tabela 13 - Estimação de parâmetros da regressão de cada variável dependente sobre OIF

\begin{tabular}{|c|c|c|c|c|c|c|c|c|c|c|}
\hline \multirow[b]{2}{*}{$\begin{array}{c}\text { Dependent } \\
\text { Variable }\end{array}$} & \multirow[b]{2}{*}{ Parameter } & \multirow[b]{2}{*}{ B } & \multirow[b]{2}{*}{$\begin{array}{l}\text { Std. } \\
\text { Error }\end{array}$} & \multirow[b]{2}{*}{$\mathbf{t}$} & \multirow[b]{2}{*}{ Sig. } & \multicolumn{2}{|c|}{$\begin{array}{c}\text { 95\% Confidence } \\
\text { Interval }\end{array}$} & \multirow[b]{2}{*}{$\begin{array}{c}\text { Eta } \\
\text { Squared }\end{array}$} & \multirow[b]{2}{*}{$\begin{array}{l}\text { Noncent. } \\
\text { Parameter }\end{array}$} & \multirow[b]{2}{*}{$\begin{array}{c}\text { Observed } \\
\text { Power }\end{array}$} \\
\hline & & & & & & $\begin{array}{l}\text { Lower } \\
\text { Bound }\end{array}$ & $\begin{array}{l}\text { Upper } \\
\text { Bound }\end{array}$ & & & \\
\hline \multirow[t]{3}{*}{$\mathrm{ROA}_{\mathrm{m}}$} & Intercep & 0,016 & 2,937 & 0,005 & 0,996 & $-5,752$ & 5,784 & 0 & 0,005 & 0,05 \\
\hline & $\mathrm{OIF} 1 \mathrm{~S}=0$ & $-2,747$ & 3,497 & $-0,785$ & 0,433 & $-9,616$ & 4,122 & 0,001 & 0,785 & 0,123 \\
\hline & $\mathrm{OIF} 1 \mathrm{~S}=1$ & $0^{\mathrm{b}}$ & & & & & & & & \\
\hline \multirow[t]{3}{*}{$\mathrm{ROE}_{\mathrm{m}}$} & Intercep & 0,056 & 3,022 & 0,019 & 0,985 & $-5,879$ & 5,992 & 0 & 0,019 & 0,050 \\
\hline & $\mathrm{OIF} 1 \mathrm{~S}=0$ & 1,985 & 3,599 & 0,552 & 0,581 & $-5,083$ & 9,054 & 0,001 & 0,552 & 0,085 \\
\hline & $\mathrm{OIF} 1 \mathrm{~S}=1$ & $0^{\mathrm{b}}$ & & & & & & & & \\
\hline \multirow[t]{3}{*}{$\mathrm{LER}_{\mathrm{m}}$} & Intercep & 2,907 & 4,098 & 0,709 & 0,478 & $-5,141$ & 10,955 & 0,001 & 0,709 & 0,109 \\
\hline & $\mathrm{OIF} 1 \mathrm{~S}=0$ & 4,640 & 4,880 & 0,951 & 0,342 & $-4,944$ & 14,224 & 0,002 & 0,951 & 0,158 \\
\hline & $\mathrm{OIF} 1 \mathrm{~S}=1$ & $0^{\mathrm{b}}$ & & & & & & & & \\
\hline \multirow[t]{3}{*}{$\mathrm{DER}_{\mathrm{m}}$} & Intercep & 1,223 & 0,758 & 1,614 & 0,107 & $-0,266$ & 2,712 & 0,004 & 1,614 & 0,364 \\
\hline & $\mathrm{OIF} 1 \mathrm{~S}=0$ & $-0,367$ & 0,903 & $-0,406$ & 0,685 & $-2,139$ & 1,406 & 0,000 & 0,406 & 0,069 \\
\hline & $\mathrm{OIF} 1 \mathrm{~S}=1$ & $0^{\mathrm{b}}$ & & & & & & & & \\
\hline \multirow[t]{3}{*}{$\mathrm{DCR}_{\mathrm{m}}$} & Intercep & 0,272 & 1,381 & 0,197 & 0,844 & $-2,441$ & 2,985 & 0,000 & 0,197 & 0,054 \\
\hline & $\mathrm{OIF} 1 \mathrm{~S}=0$ & 0,830 & 1,645 & 0,504 & 0,614 & $-2,401$ & 4,061 & 0,000 & 0,504 & 0,080 \\
\hline & $\mathrm{OIF} 1 \mathrm{~S}=1$ & $0^{\mathrm{b}}$ & & & & & & & & \\
\hline
\end{tabular}

Os dados da Tabela 13 convertem cada categoria a uma variável dicotômica focada no grupo com código mais alto. Ressalte-se que, em nenhum dos casos, foi identificado efeito significativo, além disso, convem frisar que os testes não apresentaram poder estatístico suficiente, isto é, apresentaram baixa probabilidade de identificar um efeito, se ele realmente existir. 


\subsection{Análise longitudinal baseada no modelo GLM Multivariate}

O GLM Multivariate proporciona uma análise de variância para múltiplas variáveis dependentes de um ou mais fatores e/ou co-variáveis. As variáveis do tipo fator dividem a população em grupos. Usando o GLM podem-se testar hipóteses nulas sobre os efeitos dos fatores sobre as médias de vários grupos de uma distribuição conjunta de variáveis dependentes. Podem-se investigar interações entre fatores bem como o efeito de fatores individuais. A escolha da GLM em detrimento da ANOVA tradicional foi motivada pelo fato de não ser realista assumir que uma diferença entre quaisquer dois grupos se manifestará em apenas uma variável dependente. (HAIR et al., 2005).

\subsubsection{Modelo GLM Multivariate para o estudo do efeito do incentivo fiscal e do Tempo sobre os indicadores de estrutura de capital e rentabilidade}

Nessa abordagem, foi discutido o efeito dos incentivos fiscais e do tempo sobre os indicadores de estrutura de capital e rentabilidade, isto é, compararam-se os níveis dos referidos indicadores das empresas sem e com incentivo fiscal considerando-se os valores efetivamente observados, totalizando entre 4645 e 4670 observações. A Figura 32 exibe a estrutura estilizada do modelo deste estudo.

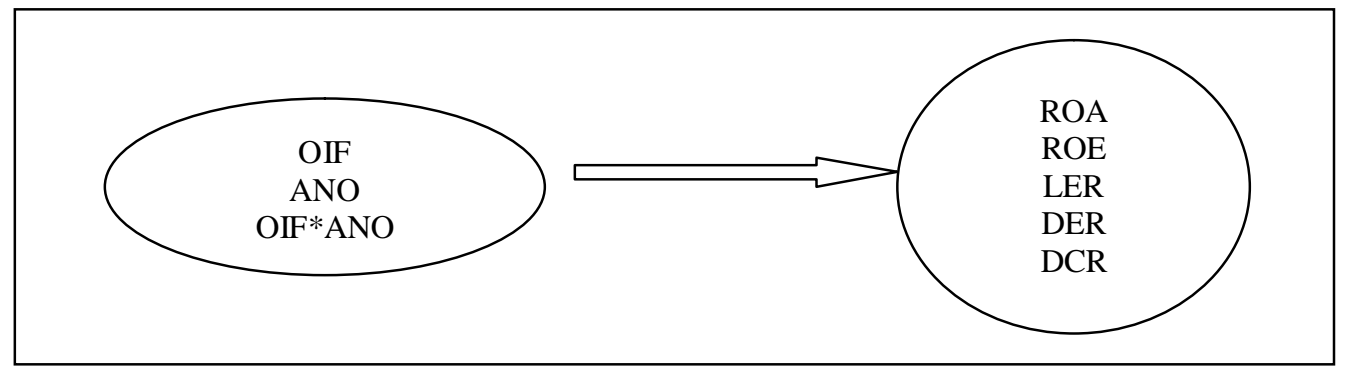

Figura 32- Relação entre incentivos fiscais e estrutura de capitais e retorno considerando a variável ano

Nos resultados da análise a seguir, por simplicidade, foram exibidos, na análise, os indicadores de estrutura de capital e retorno sem o índice “i”. 
Tabela 14 - Resultado do Teste de esfericidade de Bartlett

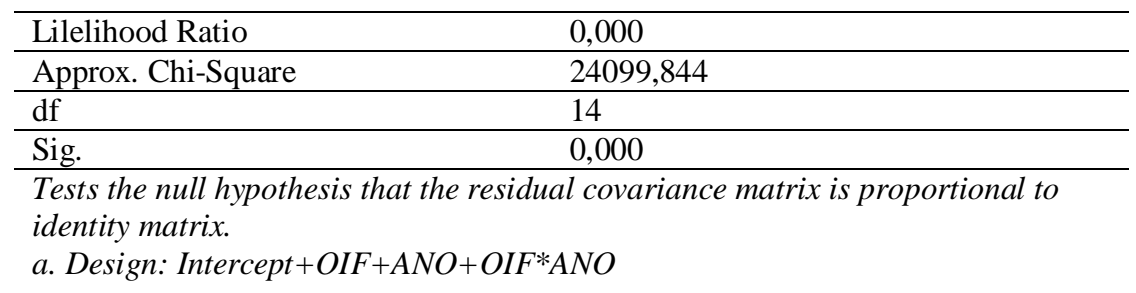

O teste recomenda a rejeição da hipótese nula $\left(\mathrm{H}_{0}\right)$ ao nível de significância de $5 \%$, portanto, existe evidência estatística de que os indicadores estão correlacionados $(p<0,001)$.

Tabela 15 - Resultado do Teste de Levene ${ }^{a}$

\begin{tabular}{l|c|c|c|c}
\hline & F & df1 & df2 & Sig. \\
\hline ROA & 1,944 & 25 & 4592 & 0,003 \\
ROE & 3,269 & 25 & 4592 & 0,000 \\
LER & 1,932 & 25 & 4592 & 0,004 \\
DER & 1,430 & 25 & 4592 & 0,076 \\
DCR & 1,622 & 25 & 4592 & 0,026 \\
\hline Tests the null hypotheses that the error variance of the dependent variable is equal \\
across groups. \\
a. Design: Intercept+OIF+ANO+OIF*ANO
\end{tabular}

Com exceção da variável DER, para cada uma das variáveis dependentes, o teste recomenda a rejeição da hipótese nula ao nível de significância de 5\%. Portanto, não existe evidência estatística de homogeneidade das variáveis dependentes ROA, ROE, LER ou DCR $(p<0,05)$; todavia, existe evidência de homogeneidade da variável DER quando se comparam os grupos definidos por OIF $(p>0,05)$.

Tabela 16 - Teste M de Box

\begin{tabular}{ll}
\hline Box'M & $82.422,654$ \\
F & 213,211 \\
df1 & 375 \\
df2 & 304.993 \\
Sig. & 0,000 \\
\hline Tests the null hypothesis that the observed covariance matrices of the dependent \\
variables are equal across groups. \\
a. Design: Intercept+OIF+ANO+OIF*ANO
\end{tabular}

O teste recomenda a rejeição da hipótese nula ao nível de significância de 5\%; portanto, existe evidência de que a matriz de covariância das variáveis dependentes no grupo $\mathrm{OIF}=0$ difere da referida matriz no grupo $\mathrm{OIF}=1$.

Os testes de Bartlett, Levene e Box discutem a adequabilidade dos dados à técnica GLM. Para que se possa utilizar a técnica, deve-se detectar correlação entre as variáveis dependentes e 
ausência de diferença nas variâncias e na matriz de covariâncias. Os dados deste estudo cumprem a primeira, mas violam as condições de variância.

Tabela 17 - Resultados dos testes multivariados

\begin{tabular}{|c|c|c|c|c|c|c|c|c|c|}
\hline Effect & & Value & $\mathbf{F}$ & $\begin{array}{c}\text { Hypothesis } \\
\text { df }\end{array}$ & $\begin{array}{c}\text { Error } \\
\text { df }\end{array}$ & Sig. & $\begin{array}{c}\text { Eta } \\
\text { Squared }\end{array}$ & $\begin{array}{c}\text { Noncent. } \\
\text { Parameter }\end{array}$ & $\begin{array}{c}\text { Observed } \\
\text { Power }^{\mathrm{a}}\end{array}$ \\
\hline \multirow[t]{4}{*}{ Intercept } & Pillai's Trace & 0,003 & $2,352^{\mathrm{b}}$ & 5 & 4588 & 0,038 & 0,003 & 11,76 & 0,758 \\
\hline & Wilks' Lambda & 0,997 & $2,352^{\mathrm{b}}$ & 5 & 4588 & 0,038 & 0,003 & 11,76 & 0,758 \\
\hline & Hotelling's Trace & 0,003 & $2,352^{\mathrm{b}}$ & 5 & 4588 & 0,038 & 0,003 & 11,76 & 0,758 \\
\hline & Roy's Largest Ro & 0,003 & $2,352^{\mathrm{b}}$ & 5 & 4588 & 0,038 & 0,003 & 11,76 & 0,758 \\
\hline \multirow[t]{4}{*}{ OIF } & Pillai's Trace & 0,001 & $1,117^{\mathrm{b}}$ & 5 & 4588 & 0,349 & 0,001 & 5,587 & 0,404 \\
\hline & Wilks' Lambda & 0,999 & $1,117^{\mathrm{b}}$ & 5 & 4588 & 0,349 & 0,001 & 5,587 & 0,404 \\
\hline & Hotelling's Trace & 0,001 & $1,117^{\mathrm{b}}$ & 5 & 4588 & 0,349 & 0,001 & 5,587 & 0,404 \\
\hline & Roy's Largest Ro & 0,001 & $1,117^{\mathrm{b}}$ & 5 & 4588 & 0,349 & 0,001 & 5,587 & 0,404 \\
\hline \multirow[t]{4}{*}{ ANO } & Pillai's Trace & 0,006 & 0,454 & 60 & 22960 & 1 & 0,001 & 27,257 & 0,691 \\
\hline & Wilks' Lambda & 0,994 & 0,455 & 60 & 21488 & 1 & 0,001 & 25,542 & 0,650 \\
\hline & Hotelling's Trace & 0,006 & 0,455 & 60 & 22932 & 1 & 0,001 & 27,293 & 0,692 \\
\hline & Roy's Largest Ro & 0,005 & $1,783^{\mathrm{C}}$ & 12 & 4592 & 0,045 & 0,005 & 21,399 & 0,892 \\
\hline \multirow{4}{*}{$\begin{array}{l}\text { OIF* } \\
\text { ANO }\end{array}$} & Pillai's Trace & 0,007 & 0,526 & 60 & 22960 & 0,999 & 0,001 & 31,54 & 0,780 \\
\hline & Wilks' Lambda & 0,993 & 0,526 & 60 & 21488 & 0,999 & 0,001 & 29,56 & 0,741 \\
\hline & Hotelling's Trace & 0,007 & 0,527 & 60 & 22932 & 0,999 & 0,001 & 31,59 & 0,781 \\
\hline & Roy's Largest Ro & 0,005 & $2,072^{\mathrm{C}}$ & 12 & 4592 & 0,016 & 0,005 & 24,85 & 0,940 \\
\hline \multicolumn{10}{|c|}{ a. Computed using alpha $=0,05$} \\
\hline \multicolumn{10}{|c|}{ b. Exact statistic } \\
\hline \multicolumn{10}{|c|}{ c. The statistic is an upper bound on F that yields a lower bound on the significance level } \\
\hline \multicolumn{10}{|c|}{ d. Design: Intercept+OIF+ANO+OIF*ANO } \\
\hline
\end{tabular}

O teste Pillai's Trace não acusa efeito significativo de OIF sobre a combinação das variáveis dependentes, o mesmo acontecendo com a variável ANO e com a interação entre ANO e OIF. 
Tabela 18 - Resultado dos testes de efeitos

\begin{tabular}{|c|c|c|c|c|c|c|c|c|c|}
\hline Source & $\begin{array}{c}\text { Dep. } \\
\text { Variable }\end{array}$ & $\begin{array}{l}\text { Type III Sum } \\
\text { of Squares }\end{array}$ & df & $\begin{array}{c}\text { Mean } \\
\text { Square }\end{array}$ & $\mathbf{F}$ & Sig. & $\begin{array}{c}\text { Eta } \\
\text { Squared }\end{array}$ & $\begin{array}{l}\text { Noncent. } \\
\text { Parameter }\end{array}$ & $\begin{array}{c}\text { Observed } \\
\text { Power }^{\mathrm{a}}\end{array}$ \\
\hline \multicolumn{10}{|l|}{ Corrected } \\
\hline \multirow[t]{5}{*}{ Model } & ROA & $10619,61^{b}$ & 25 & 424,79 & 0,541 & 0,969 & 0,003 & 13,534 & 0,499 \\
\hline & ROE & $715,35^{\mathrm{c}}$ & 25 & 28,61 & 1,483 & 0,058 & 0,008 & 37,071 & 0,972 \\
\hline & LER & $63064,16^{\mathrm{b}}$ & 25 & 2522,57 & 0,633 & 0,919 & 0,003 & 15,835 & 0,587 \\
\hline & DER & $5075,27^{\mathrm{d}}$ & 25 & 203,01 & 0,482 & 0,986 & 0,003 & 12,056 & 0,441 \\
\hline & DCR & $12648,74^{\mathrm{d}}$ & 25 & 505,95 & 0,515 & 0,978 & 0,003 & 12,873 & 0,473 \\
\hline \multirow[t]{5}{*}{ Intercept } & ROA & 123,58 & 1 & 123,58 & 0,158 & 0,691 & 0,000 & 0,158 & 0,068 \\
\hline & ROE & $9,49 \mathrm{E}-02$ & 1 & $9,49 \mathrm{E}-02$ & 0,005 & 0,944 & 0,000 & 0,005 & 0,051 \\
\hline & LER & 27864,90 & 1 & 27864,90 & 6,997 & 0,008 & 0,002 & 6,997 & 0,753 \\
\hline & DER & 3131,70 & 1 & 3131,70 & 7,439 & 0,006 & 0,002 & 7,439 & 0,778 \\
\hline & DCR & 344,47 & 1 & 344,47 & 0,351 & 0,554 & 0,000 & 0,351 & 0,091 \\
\hline \multirow[t]{5}{*}{ OIF } & ROA & 170,29 & 1 & 170,29 & 0,217 & 0,641 & 0,000 & 0,217 & 0,075 \\
\hline & ROE & 88,15 & 1 & 88,15 & 4,568 & 0,033 & 0,001 & 4,568 & 0,570 \\
\hline & LER & 870,93 & 1 & 870,93 & 0,219 & 0,640 & 0,000 & 0,219 & 0,075 \\
\hline & DER & 1,85 & 1 & 1,85 & 0,004 & 0,947 & 0,000 & 0,004 & 0,051 \\
\hline & DCR & 30,06 & 1 & 30,06 & 0,031 & 0,861 & 0,000 & 0,031 & 0,054 \\
\hline \multirow[t]{5}{*}{ ANO } & ROA & 912,56 & 12 & 76,05 & 0,097 & 1,000 & 0,000 & 1,163 & 0,084 \\
\hline & ROE & 284,35 & 12 & 23,70 & 1,228 & 0,257 & 0,003 & 14,736 & 0,713 \\
\hline & LER & 7734,19 & 12 & 644,52 & 0,162 & 0,999 & 0,000 & 1,942 & 0,111 \\
\hline & DER & 1020,69 & 12 & 85,06 & 0,202 & 0,998 & 0,001 & 2,425 & 0,129 \\
\hline & DCR & 1369,98 & 12 & 114,17 & 0,116 & 1,000 & 0,000 & 1,394 & 0,091 \\
\hline \multirow[t]{5}{*}{ OIF*ANO } & ROA & 916,25 & 12 & 76,35 & 0,097 & 1,000 & 0,000 & 1,168 & 0,084 \\
\hline & ROE & 337,35 & 12 & 28,11 & 1,457 & 0,133 & 0,004 & 17,482 & 0,803 \\
\hline & LER & 12492,26 & 12 & 1041,02 & 0,261 & 0,994 & 0,001 & 3,137 & 0,159 \\
\hline & DER & 1302,55 & 12 & 108,55 & 0,258 & 0,995 & 0,001 & 3,094 & 0,157 \\
\hline & DCR & 1464,27 & 12 & 122,02 & 0,124 & 1,000 & 0,000 & 1,490 & 0,095 \\
\hline \multirow[t]{5}{*}{ Error } & ROA & 3603123,15 & 4592 & 784,65 & & & & & \\
\hline & ROE & 88611,01 & 4592 & 19,30 & & & & & \\
\hline & LER & 18288104,40 & 4592 & 3982,60 & & & & & \\
\hline & DER & 1933163,72 & 4592 & 420,99 & & & & & \\
\hline & DCR & 4512044,85 & 4592 & 982,59 & & & & & \\
\hline \multirow[t]{5}{*}{ Total } & ROA & 3615078,52 & 4618 & & & & & & \\
\hline & ROE & 89437,04 & 4618 & & & & & & \\
\hline & LER & 18449831,44 & 4618 & & & & & & \\
\hline & DER & 1946644,38 & 4618 & & & & & & \\
\hline & DCR & 4526307,48 & 4618 & & & & & & \\
\hline \multicolumn{10}{|l|}{ Corrected } \\
\hline \multirow[t]{5}{*}{ Total } & ROA & 3613742,77 & 4617 & & & & & & \\
\hline & ROE & 89326,37 & 4617 & & & & & & \\
\hline & LER & 18351168,56 & 4617 & & & & & & \\
\hline & DER & 1938238,99 & 4617 & & & & & & \\
\hline & DCR & 4524693,59 & 4617 & & & & & & \\
\hline \multicolumn{10}{|c|}{ a. Computed using alpha $=0,05$} \\
\hline \multicolumn{10}{|c|}{ b. $R$ Squared $=0,003$ (Adjusted $R$ Squared $=-0,002)$} \\
\hline \multicolumn{10}{|c|}{ c. $R$ Squared $=0,008$ (Adjusted $R$ Squared $=0,003)$} \\
\hline d. $R$ Square & $=0,003(\mathrm{~A}$ & justed R Squarec & $=-0,00$ & & & & & & \\
\hline
\end{tabular}

O exame do $R$-Square associado à Regressão Múltipla Multidimensional (Tabela 18) sugere uma fraquíssima aderência do modelo ajustado aos dados em questão, o que já foi antevisto na Tabela 17. Considerando os dados da Tabela 18, é possível identificar um efeito isolado estatisticamente significativo da OIF sobre o ROE $(p=0,033)$. Oportuno observar que o ANO ou a interação entre ANO e OIF não se mostraram efetivos na previsão dos valores dos indicadores de estrutura de capital e rentabilidade.

A despeito da GLM Univariate e Multivariate não terem apresentado resultados significativos, um modelo de pesquisa do relacionamento entre incentivos fiscais, os indicadores de estrutura de capital e os de rentabilidade, sugerido pelos resultados é apresentado na Figura 33. 


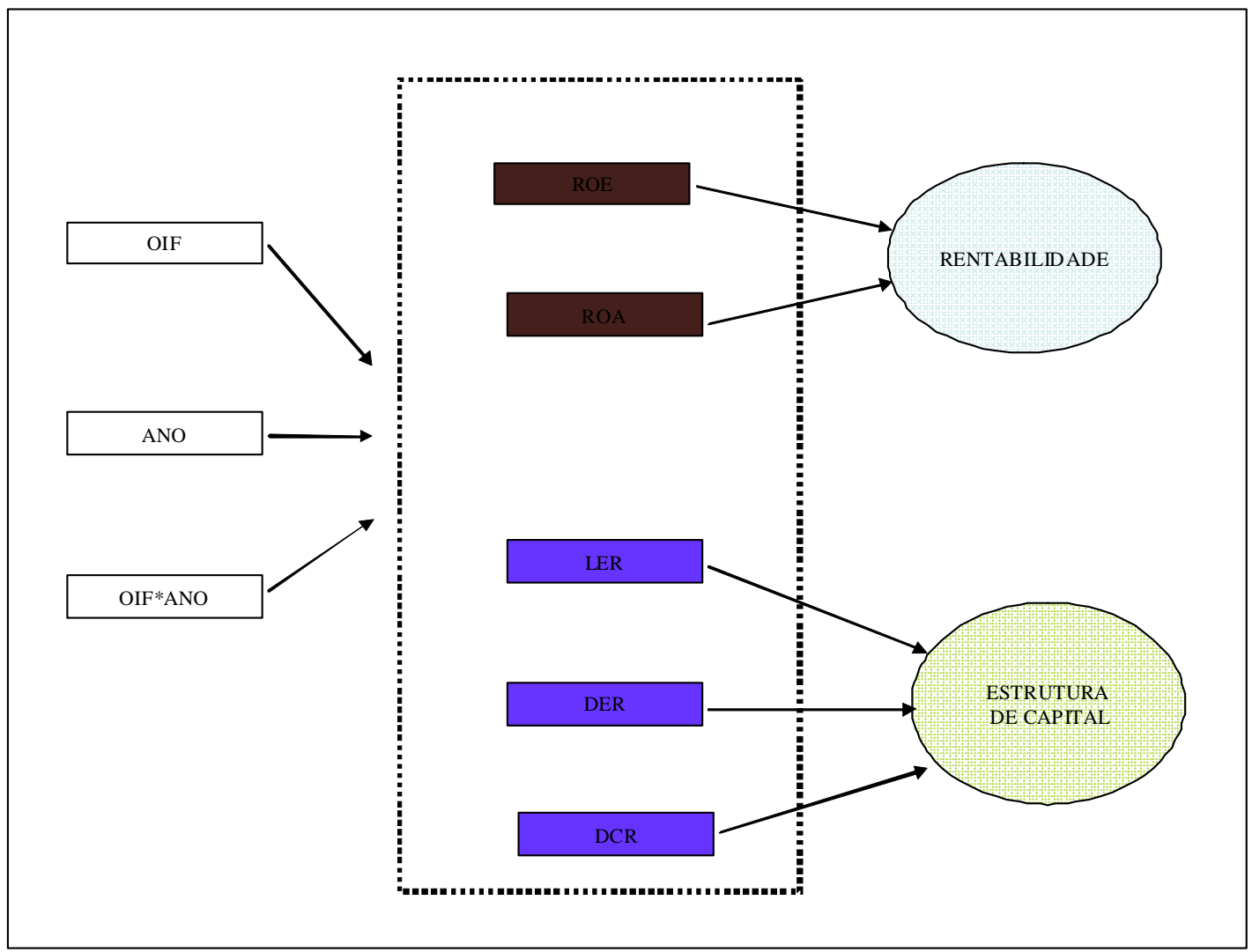

Figura 33: Modelo de pesquisa de relacionamento entre incentivos fiscais, os indicadores de estrutura de capital e os de rentabilidade 


\section{DISCUSSÃO DOS RESULTADOS}

\section{1 a Parte: Discussão dos Resultados Periféricos (Perfil das Companhias)}

Estima-se que a proporção de companhias abertas brasileiras não financeiras que usufruíram de incentivos fiscais no período de 1995 a 2007 foi de 29\% com uma margem de erro de $3,66 \%$, isto é, estima-se que a proporção real tenha variado de $25,34 \%$ a $32,55 \%$. Presume-se que esse resultado não seja maior em virtude da complexidade da legislação brasileira que dificulta o acesso das empresas à obtenção de recursos governamentais.

O estudo sugere associação entre ausência de incentivo fiscal e os setores comércio, eletroeletrônicos, energia, máquinas industriais e papel/celulose e sugere associação entre presença de incentivo fiscal e o setor de telecomunicações.

As empresas incentivadas apresentaram tempo médio de operação maior do que o das empresas não incentivadas.

As empresas incentivadas apresentaram nível de tributação médio superior ao das empresas não incentivadas. Presume-se, nesse caso, que isso seja devido à forma de contabilização dos incentivos fiscais que acaba gerando essa anomalia.

O número de empresas que usufruíram de incentivo fiscal no período de 1995 a 2007 diminuiu a cada ano a uma taxa média de 5,4\%. Presume-se que isso seja devido à tentativa do governo em melhorar o controle na concessão de incentivos, aumentando as exigências para a sua concessão.

Não foi possível rejeitar a hipótese de que o crescimento das vendas nas empresas com incentivo seja equivalente ao das empresas sem incentivo. Esse resultado conflita com os achados por Barron et al. (1994) e Goddard et al. (2002) que afirmam haver um crescimento de vendas maior nas empresas incentivadas do que nas não incentivadas. Esse resultado pode ter sido resultante das várias observações discrepantes constantes no banco de dados deste estudo. 
Identificou-se uma tendência de queda na taxa de crescimento do número de empresas incentivadas. Considerando que o valor da renúncia fiscal vem aumentando a cada ano, conforme demonstrado na introdução deste estudo, e o número de empresas beneficiadas pelos incentivos fiscais vem diminuindo, uma possível justificativa para a diminuição do número de empresas que são beneficiadas pelos incentivos fiscais pode ser que um menor número de empresas, individualmente, venha se beneficiando de um volume maior de recursos. Essa justificativa encontra-se em consonância com o estudo de Goddard et al. (2002, p. 1) em que ele afirma que houve uma concentração no número de cooperativas de crédito nos EUA que usufruem de incentivos fiscais. Outra possível justificativa é que as empresas que estejam se beneficiando dos incentivos não estejam compondo a amostra deste estudo, como é o caso, por exemplo, das companhias fechadas, das microempresas e das empresas de pequeno porte.

Cerca de $47 \%$ das empresas incentivadas usufruíram de menos de $\mathrm{R} \$ 250.000$ enquanto 39\% usufruíram de mais de $\$ 750.000$. O valor médio usufruído no período foi de $\mathrm{R} \$ 4.805 .000$. Verifica-se, portanto, uma grande amplitude no valor dos incentivos fiscais usufruídos pelas empresas.

\section{$\underline{2^{\mathrm{a}}}$. Parte $=$ Discussão do Problema de Pesquisa}

Para este estudo foram estruturadas duas hipóteses de pesquisa $\left(\mathrm{H}_{1}\right.$ e $\mathrm{H}_{2}$ apresentadas no subitem 1.3), porém para efeito estatístico, é necessário que as hipóteses de pesquisa investigadas sejam convertidas em hipóteses estatísticas.

Assim, a hipótese de pesquisa $\mathrm{H}_{1}$ equivale às seguintes hipóteses estatísticas:

$\mathbf{H}_{11}$ : Empresas que usufruíram incentivos fiscais tendem a apresentar um LER médio inferior ao observado nas empresas que não usufruíram incentivos fiscais.

H12: Empresas que usufruíram incentivos fiscais tendem a apresentar DER médio inferior ao observado nas empresas que não usufruíram incentivos fiscais.

$\mathbf{H}_{13}$ : Empresas que usufruíram incentivos fiscais tendem a apresentar DCR médio inferior ao observado nas empresas que não usufruíram incentivos fiscais. 
A hipótese de pesquisa $\mathrm{H}_{2}$ equivale às seguintes hipóteses estatísticas:

$\mathbf{H}_{21}$ : Empresas que usufruíram incentivos fiscais tendem a apresentar um ROA médio superior ao observado nas empresas que não usufruíram incentivos fiscais.

$\mathbf{H}_{22}$ : Empresas que usufruíram incentivos fiscais tendem a apresentar um ROE médio superior ao observado nas empresas que não usufruíram incentivos fiscais.

Discussão do resultado quanto a $\mathrm{H}_{11}, \underline{\mathrm{H}}_{12}$ e $\mathrm{H}_{13}$

$\mathrm{Na}$ análise da hipótese estatística $\mathrm{H}_{11}$ (incentivo $\rightarrow$ redução no LER), na comparação da distribuição do LER das empresas sem incentivo com a das empresas com incentivo, o teste $\mathrm{U}$ de Mann-Whitney não acusou diferença estatisticamente significativa entre as referidas distribuições. Entretanto, tal resultado não demonstra que as distribuições sejam iguais, mas somente que não foi possível refutar a hipótese de sua igualdade e, por conseqüência, os valores médios de LER nos dois grupos são iguais. A análise GLM confirmou o resultado observado no teste U. Assim, diante dos resultados apurados não foi possível confirmar a hipótese estatística $\mathrm{H}_{11}$.

$\mathrm{Na}$ análise da hipótese estatística $\mathrm{H}_{12}$ (incentivo $\rightarrow$ redução no DER), na comparação da distribuição do DER das empresas sem incentivo com a das empresas com incentivo, apuraram-se os mesmos resultados obtidos na hipótese estatística $\mathrm{H}_{11}$. Assim, diante dos resultados apurados não foi possível confirmar a hipótese estatística $\mathrm{H}_{12}$.

$\mathrm{Na}$ análise da hipótese estatística $\mathrm{H}_{13}$ (incentivo $\rightarrow$ redução no DCR), na comparação da distribuição do DCR das empresas sem incentivo com a das empresas com incentivo, apuraram-se os mesmos resultados obtidos na hipótese estatística $\mathrm{H}_{11}$. Assim, não foi possível confirmar a hipótese estatística $\mathrm{H}_{13}$.

O resultado acima está em desacordo com o encontrado por Tatom (2005) que, em um estudo envolvendo as cooperativas de crédito nos EUA, concluiu que a isenção fiscal acarreta uma redução do capital de terceiros na composição da estrutura de capital. Essa desconformidade entre os resultados pode ser decorrente dos critérios de seleção muito amplos deste estudo que incluiu empresas cujos dados apresentavam amplitudes consideravelmente discrepantes. 


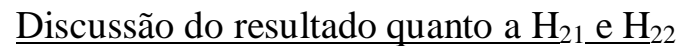

$\mathrm{Na}$ análise da hipótese estatística $\mathrm{H}_{21}$, quando se compara a distribuição do ROA das empresas sem incentivo com a das empresas com incentivo, o teste U de Mann-Whitney acusou diferença estatisticamente significativa entre as referidas distribuições. Os resultados sugerem que empresas com incentivo fiscal tendem a apresentar uma distribuição do ROA com valores superiores aos das empresas sem incentivo e, por conseqüência, tendem a apresentar ROA médio superior ao das empresas sem incentivo. $\mathrm{O}$ resultado oferece uma evidência a favor da hipótese estatística $\mathrm{H}_{21}$.

$\mathrm{Na}$ análise da hipótese estatística $\mathrm{H}_{22}$, quando se compara a distribuição do ROE das empresas sem incentivo com a das empresas com incentivo apuraram-se os mesmos resultados, o que sugere que empresas com incentivo fiscal tendem a apresentar uma distribuição do ROE com valores superiores aos das empresas sem incentivo, por conseqüência, tendem a apresentar ROE médio superior ao das empresas sem incentivo. Oportuno observar que a análise GLM corroborou o resultado referido, que oferece evidências a favor da hipótese estatística $\mathrm{H}_{22}$.

Os resultados apurados para o ROA e ROE estão de acordo com Santos e Candiota (1974) que pesquisaram sociedades de créditos imobiliários no Brasil e concluíram que os incentivos fiscais tiveram um efeito relevante na rentabilidade do ativo dessas empresas; com Roesch (1984) que concluiu que os incentivos fiscais aumentam o desempenho econômico das empresas e, também, está de acordo com Tatom (2005) que, em um estudo envolvendo cooperativas de créditos nos EUA, encontrou que a incidência da isenção fiscal acarreta aumento no ROA e no ROE daquelas instituições. O resultado encontrado neste estudo sinaliza que os incentivos fiscais influenciam a rentabilidade das empresas o que é uma constatação da hipótese de pesquisa $\mathrm{H}_{2}$. 


\section{CONCLUSÕES}

Este trabalho de pesquisa teve como objetivo principal investigar o efeito do incentivo fiscal na estrutura de capital e na rentabilidade das companhias abertas brasileiras não financeiras com ações negociadas na Bovespa. As hipóteses defendidas no estudo foram: $\mathbf{H}_{1}$ : Os incentivos fiscais afetam a estrutura de capital das companhias abertas brasileiras não financeiras, reduzindo o nível de endividamento. $\mathbf{H}_{2}$ : Os incentivos fiscais afetam a rentabilidade das companhias abertas brasileiras não financeiras, aumentando o retorno do ativo e do patrimônio líquido.

Tais hipóteses foram estudadas em 590 empresas das quais 29\% usufruíram de incentivos fiscais no período; 55,9 \% tinham ações do tipo PN; 13,6\% eram do setor comercial; o tempo médio de operação no período foi de 7,91 anos; o tempo médio de usufruto de incentivos fiscais foi de 3,1 anos; o nível médio de tributação foi de 32\%; o crescimento médio de vendas foi de $36 \%$ e a taxa média anual de crescimento do número de empresas incentivadas foi de $-5,44 \%$. Quanto aos indicadores de estrutura de capital, as empresas apresentaram um LER médio de 6,18; um DER médio de 0,96 e um DCR médio de 0,86. Quanto aos indicadores de rentabilidade, as empresas apresentaram um ROA médio de -1,92 e um ROE médio de 1,46 .

Os principais achados do estudo foram: uma proporção de cerca de 1/3 de companhias incentivadas; a tendência das companhias comerciais, eletroeletrônicas, energia, máquinas industriais e papel/celulose não obterem incentivos fiscais; a tendência de empresas do setor das telecomunicações obterem tais incentivos; maior tempo de operação no mercado ligado a empresas incentivadas; maior nível de tributação ligado a empresas incentivadas; ausência de correlação entre crescimento de vendas e incentivos fiscais; tendência de queda no número de empresas incentivadas; não se identificou correlação estatisticamente significativa entre incentivo fiscal e os indicadores de endividamento das empresas; identificou-se correlação estatisticamente significativa entre incentivo fiscal e os indicadores de rentabilidade das empresas.

Considerando as características próprias de um estudo baseado em amostras e, portanto, sujeito a uma variedade de vieses não passíveis de controle total e assumindo como razoável 
admitir que os indicadores ROA e ROE medem a rentabilidade e os indicadores LER, DER e DCR medem a estrutura de capital, pode-se deduzir que o objetivo principal deste trabalho foi alcançado, na medida em que foi possível reunir evidências de que a rentabilidade do ativo e do patrimônio líquido tendem a aumentar nas companhias abertas brasileiras que usufruem de incentivos fiscais, influenciando, portanto, o seu desempenho.

O estudo apresenta diversas limitações, dentre as quais: a forma de contabilização dos incentivos fiscais, que não transitavam pelo resultado do exercício; o uso de critérios de seleção muito amplos, o que incluiu empresas cujos dados apresentaram demasiadas amplitudes e empresas com resultados discrepantes como, por exemplo, empresas com lucro contábil e sem imposto a pagar, com lucro contábil e com receita de imposto de renda, e com prejuízo contábil e com imposto de renda a pagar.

Acredita-se que o estudo tenha contribuído academicamente com uma organização do desenvolvimento da pesquisa (vide seção 3.1); com a descrição do perfil das companhias abertas brasileiras não financeiras; com um modelo de relacionamento entre incentivo fiscal, estrutura de capital e rentabilidade; e com uma discussão do efeito dos incentivos sobre a estrutura de capital e rentabilidade. Acredita-se que a organização do estudo e o modelo de relacionamento possam ainda ser utilizados no cenário empresarial como modelos de avaliação de desempenho.

Dentre as diversas possibilidades de estudos futuros que o presente estudo sinaliza, consideram-se estudos que possam ser conduzidos com controles de coleta mais restritos, considerando metodologias mais robustas e incluindo outros indicadores de desempenho. Alem disso, acredita-se que novas variáveis de caracterização possam ser incluídas, tais como: nível de responsabilidade social, número de empregados, controle acionário e outras. Também, pode-se imaginar uma versão do GLM Multivariate que incorpore outras variáveis independentes alem do incentivo fiscal e do tempo.

Nos EUA, as pesquisas (TATOM, 2005, p. 1-2) indicaram que os cooperados recebem a isenção tributária das cooperativas de crédito como retornos extraordinários; assim, outra possibilidade de pesquisa é esclarecer, no Brasil, quem se beneficia dos incentivos fiscais usufruídos pelas empresas. 
Em virtude de que os incentivos têm como objetivo principal o desenvolvimento de atividades ou regiões que por si só não teriam condições de desenvolvimento, sugere-se que futuros estudos avaliem qual foi o benefício gerado à sociedade pelos incentivos fiscais.

Outra questão a ser esclarecida é em que momento a empresa já se beneficiou dos incentivos fiscais o suficiente para desenvolver-se por conta própria e, assim, o governo pode deixar de concedê-los? 


\section{REFERÊNCIAS}

AGUIAR, Pollyanna Mara de Castro. Isenção e imunidade tributárias: qual a natureza jurídica? Dez. 2002. Disponível em: 〈http://www.jfrn.gov.br/docs/doutrina190.doc>. Acesso em: 30/09/2006.

AGUIAR, Teresinha de Jesus Alves de; MONTEIRO, Maria do Socorro Lira. Modelo agrícola e desenvolvimento sustentável: a ocupação do cerrado piauiense. Revista Ambiente \& Sociedade, v. VIII, n. 2, Jul./Dez. 2005.

AMBURGEY, T. L.; DACIN, M. T. Evolutionary Development of Credit Unions. Center for Credit Union Research. The School of Business, University of Wisconsin-Madison, 1993.

ANUATTI-NETO, Francisco et al. Os efeitos da privatização sobre o desempenho econômico e financeiro das empresas privatizadas. Revista Brasileira de Economia. Rio de Janeiro, v. 59, n. 2, p. 151-175, Abr./Jun. 2005.

ASSAF NETO, Alexandre. Finanças corporativas e valor. 2. ed. São Paulo: Atlas, 2006.

Estrutura e análise de balanços: um enfoque econômico-financeiro. 7. ed. São Paulo: Atlas, 2002.

ATALIBA, Geraldo; GONÇALVES, José Artur Lima. Crédito-prêmio de IPI - direito adquirido - recebimento em dinheiro. Revista de Direito Tributário. São Paulo: Revista dos Tribunais, v. 55, p. 167.

ATKINSON, Anthony A. et al. Contabilidade gerencial. Tradução de André Olímpio Mosselman Du Chenoy Castro. 2. ed. São Paulo: Atlas, 2008.

AUGUSTO, Ana Maria Ferraz. Incentivos: instrumentos jurídicos do desenvolvimento. Revista de Direito Público. v. 47-48, p. 279, 2006.

AVILA, Jaime Plá Pujades de. Isenção tributária e institutos afins. 2005. Disponível em: <http://www.avocato.com.br/doutrina/2005.lcn1.htm.> Acesso em: 10/09/2006.

BANCO CENTRAL DO BRASIL. Boletim do Banco Central do Brasil. Relatório anual 2005, p. 77-98. Disponível em: <http://www.bcb.gov.br/htms/banual2005/rel2005cap4p.pdf>. Acesso em: 12/01/2008.

BARNEY, Jay B. Gaining and Sustaining Competitive Advantage. New Jersey: Pearson Prentice Hall, 2007.

BARRON, D. N. Credit Unions: Density-Dependent Evolution. 1992.

et al. A time to grow and a time to die: growth and mortality of credit unions in New York City, 1914-1990. The American Journal of Sociology. v. 100, n. 2, p. 381-421, Sep. 1994.

BERGER, Allen N. et al. The efficiency of financial institutions: A Review and Preview of Research Past, Present and Future. Journal of Banking and Finance. v. 17, n. 2-3, p. 221249, April 1993. 
et al. The consolidation of the financial services industry: causes, consequences and implications for the future. Journal of Banking and Finance. v. 23, n. 2-4, p. 135-194, Feb. 1999.

BERLE, Adolf A.; MEANS, Gardiner C. A moderna sociedade anônima e a propriedade privada. Os economistas. Nova Cultural, 1987.

BERMAN, Graça et al. Patrocínio empresarial e incentivos fiscais à cultura no Brasil: análise de uma experiência recente. Revista de Administração de Empresas. v. 37, n. 4, out./dez. 1997. Seção: Administração Mercadológica.

BERTOLUCCI, Aldo V.; NASCIMENTO, Diogo Toledo do. O custo da arrecadação de tributos federais. Revista de Contabilidade e Finanças. Edição comemorativa, p. 36-50, 30/09/2006.

BLACK, Harold; DUGGER, Robert H. Credti union structure, growth and regulatory problems. The Journal of Finance. V. 36, n. 2, p. 529-538, May 1981.

BORGES, José Souto Maior. Teoria geral da isenção tributária. 3. ed. rev. e atual. 2. tiragem. São Paulo: Malheiros, 2007.

BRAMI-CELENTANO, Alexandrine; CARVALHO, Carlos Eduardo. A reforma tributária do governo Lula: continuísmo e injustiça fiscal. Revista Katálysis. v. 10, n. 1, p. 44-53, jun. 2007.

BRASIL. Constituição Federal, código comercial, código tributário nacional / organizadora do código comercial Vera Helena de Mello Franco; organizador do código tributário nacional Roque Antonio Carrazza. 3. ed. rev. atual. e ampl. São Paulo: Revista dos Tribunais, 2001 - (RT-mini-códigos).

<http://www.ipea.gov.br/default.jsp>. Acesso em: 05/01/2008.

Lei 6.404 de 15 de dezembro de 1976. Dispõe sobre as sociedades por ações. Diário Oficial da União, Brasília, 17 dez. 1976 (suplemento).

Lei 11.638 de 28 de dezembro de 2007. Altera e revoga dispositivos da Lei $\mathrm{n}^{\mathrm{o}}$ 6.404, de 15 de dezembro de 1976, e da Lei n⿳ ${ }^{0}$ 6.385, de 7 de dezembro de 1976, e estende às sociedades de grande porte disposições relativas à elaboração e divulgação de demonstrações financeiras. Diário Oficial da União, Brasília, 28 dez. 2007 (Edição extra).

Lei Complementar 101, de 04 de maio de 2000. Estabelece normas de finanças públicas voltadas para a responsabilidade na gestão fiscal e dá outras providências. Diário Oficial da União, Brasília, 05 maio 2000.

2008.

Ministério do Planejamento, Orçamento e Gestão. Projeto de Lei Orçamentária

<http://www.planejamento.gov.br/orcamento/conteudo/orcamento 2008/orcamento $2008 \mathrm{ht}$ $\underline{\mathrm{m}}>$. Acesso em: 05/01/2008. 


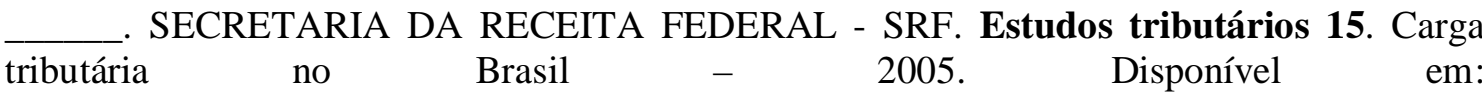
<http://www.receita.fazenda.gov.br/Publico/estudotributarios/estatisticas/CTB2005.pdf>. Acesso em: 04/09/2006.

SECRETARIA DA RECEITA FEDERAL - SRF. Decreto n- 3.000, de 26 de março de 1999. Regulamenta a tributação, fiscalização, arrecadação e administração do Imposto sobre a Renda e Proventos de Qualquer Natureza Disponível em: <http://www.receita.fazenda.gov.br>. Acesso em: 04/09/2006.

Tribunal de Contas da União. Relatório e pareceres prévios sobre as contas do governo da república: exercício de 2006. Ministro Ubiratan Aguiar, relator. Brasília: TCU, 2007. 360 p. Disponível em: <http://www.tcu.gov.br>. Acesso em: 07/08/2007.

BUSSAB W; MORETTIN P. A. Estatistica básica. 5. ed. São Paulo: Saraiva, 2002.

BUTTERS, J. Keith. Federal income taxation and external vs. internal financing. The Journal of Finance. v. 4, n. 3, p. 197-205, Sep. 1949.

CARDOSO, Roberto Carvalho. A reavaliação do ativo imobilizado frente aos incentivos fiscais. Revista de Administração de Empresas. Rio de Janeiro, v. 11, n. 3, p. 77-84, jul./set. 1971.

CARVALHO, L. Nelson et al. Contabilidade internacional: aplicação das IFRS 2005. São Paulo: Atlas, 2006.

CARVALHOSA, Modesto. Comentários à Lei de Sociedades Anônimas, v. III. São Paulo: Saraiva, 1997, p. 603.

CASTILHO, V. Estudo do processo de controle de gasto de material de consumo em unidades de saúde. Projeto - Proposição de um quadro referencial sobre custos da enfermagem. São Paulo: FAPESP, 2002.

CERVO, Amado Luiz; BERVIAN, Pedro Alcino. Metodologia científica. 5. ed. São Paulo: Prentice Hall, 2002.

CHRISTIANS, Raimundo L. M. et al. International transfer pricing restrictions: impact on corporate financial policy. Revista de Administração de Empresas. v. 37, n.3, 1997. Seção: administração contábil e financeira.

COLLIS, Jill; HUSSEY, Roger. Pesquisa em administração: um guia prático para alunos de graduação e pós-graduação.Tradução de Lucia Simonini. 2. ed. Porto Alegre: Bookman, 2005.

COMISSÃO DE VALORES MOBILIÁRIOS - CVM. Deliberação CVM no 488, de 03 de outubro de 2005. Disponível em: <www.cvm.gov.br>. Acesso em: 05/05/2007.

Deliberação CVM no 29 de 05 de fevereiro de 1986. Disponível em: <www.cvm.gov.br>. Acesso em: 05/05/2007. 
Deliberação CVM no 539 de 14 de março de 2008. Aprova o Pronunciamento Conceitual Básico do CPC que dispõe sobre a Estrutura Conceitual para a Elaboração e Apresentação das Demonstrações Contábeis. Disponível em: 〈www.cvm.gov.br〉. Acesso em: 15/05/2008.

Instrução CVM no 59 de 22 de dezembro de 1986. Dispõe sobre a obrigatoriedade de elaboração e publicação da demonstração das mutações do patrimônio líquido pelas companhias abertas. Disponível em: <www.cvm.gov.br>. Acesso em: 05/05/2007.

Instrução CVM n- 469 de 02 de maio de 2008. Dispõe sobre a aplicação da Lei $\mathbf{n}^{\circ}$ 11.638, de 28 de dezembro de 2007. Altera as Instruções CVM nำ 247, de 27 de março de 1996 e 331, de 4 de abril de 2000. Disponível em: <www.cvm.gov.br>. Acesso em: 05/05/2008.

- OFÍCIO-CIRCULAR/CVM/SNC/SEP № 01/2007. Orientação sobre Normas Contábeis pelas Companhias Abertas. Disponível em: <www.cvm.gov.br〉. Acesso em: 05/05/2007.

Nota explicativa da Instrução CVM no 59, de 22 de dezembro de 1986. Disponível em <http://www.cvm.gov.br>. Acesso em: 03/09/2007.

Nota explicativa à Instrução CVM no 469, de 02 de maio de 2008. Disponível em <http://www.cvm.gov.br>. Acesso em: 03/09/2007.

COMITÊ DE PRONUNCIAMENTOS CONTÁBEIS - CPC. Disponível em: $<$ http//:www.cpc.org.br>. Acesso em: 05/05/2007.

CONSELHO FEDERAL DE CONTABILIDADE - CFC. Resolução CFC no 750 de 29 de dezembro de 1993. Dispõe sobre os Princípios Fundamentais de Contabilidade. Disponível em: <http//:www.cfc.org.br>. Acesso em: 05/05/2007.

Resolução CFC no 1.026 de 15 de abril de 2005. Aprova a NBC T 19.4 - Incentivos Fiscais, Subvenções, Contribuições, Auxílios e Doações Governamentais. Disponível em: <http//:www.cfc.org.br>. Acesso em: 05/05/2007.

Resolução CFC no 1.055 de 07 de outubro de 2005. Cria o Comitê de Pronunciamentos Contábeis - (CPC), e dá outras providências. Disponível em: $<$ http//:www.cfc.org.br>. Acesso em: 05/05/2007.

CORRAR, Luiz João et al. Detecção do gerenciamento de resultados pela análise do diferimento tributário. Revista de Administração de Empresas. v. 47, n. 1, 2007. Seção: artigos.

COSTA, Alcides J. Imposto de vendas e consignações: análise dos sistemas de arrecadação. Revista de Administração de Empresas. v. 3, n. 6, 1963. Seção: artigos.

CROSSING. Receita da Positivo cresce 84,4\% e atinge $\mathbf{R} \$ \mathbf{1 , 3 5}$ bi. Disponível em <http://www.crossing.com.br/clipp/materias/pan070316.htm>. Acesso em: 20/03/2007. ano 6, ed. 261. 
CROTEAU, John T. The large credit union. The Journal of Finance. v. 11, n. 3, p. 347-362, sep. 1956.

CYRINO, Alvaro Bruno; DORNAS, Guilherme Costa Vale. Intensidade competitiva, performance financeira e sustentabilidade: uma análise longitudinal do desempenho econômico-financeiro das 500 maiores e melhores empresas do Brasil no período 1990-1999. Fundação Dom Cabral, Caderno de Idéias - CIO223, dez. 2002.

DAIN, Sulamis. Os vários mundos do financiamento da Saúde no Brasil: uma tentativa de integração. Ciência \& Saúde Coletiva. v. 12 (Sup.), p. 1851-1864, 2007.

et al. Renúncia Fiscal e Assistência Médica Suplementar. In: Regulação \& Saúde: estrutura, evolução e perspectivas da assistência médica suplementar. Rio de Janeiro: Agência Nacional de Saúde Suplementar, 2002.

DAVIES, Nicholas. Fundeb: a redenção da educação básica? Educação Social. Campinas, vol. 27, n. 96 - Especial, p. 753-774, out. 2006.

DeANGELO, H.; MASULIS, R. W. Optimal capital structure under corporate and personal taxation. Journal of Financial Economics. v. 8, n. 1, p. 3-29, Mar. 1980.

DINIZ, Marcelo de Lima Castro; FORTES, Fellipe Cianca. Incentivos fiscais no STJ. In: MARTINS, Ives Gandra da Silva et al. (Coord.). Incentivos fiscais: questões pontuais nas esferas federal, estadual e municipal. São Paulo: MP, 2007. cap. 14, p. 265-297.

; RIBEIRO, Maria de Fátima. O direito ao crédito-prêmio do IPI. Jus Navigandi,

Teresina, ano 8, n. 379, 21 jul. 2004. Disponível em: <http://jus2.uol.com.br/doutrina/texto.asp?id=5471>. Acesso em: 07 set. 2008.

DUNNE, P.; HUGHES, A. Age, Size Growth and Survival: UK Companies in the 1980's. Journal of Industrial Economics. n. 42, p. 115-140, 1994.

DURAND, José Carlos Garcia et al. Patrocínio empresarial e incentivos fiscais à cultura no Brasil: análise de uma experiência recente. Revista de Administração de Empresas. São Paulo, v. 37, n. 4, p. 38-44, out./dez. 1997.

ELALI, André. Incentivos fiscais, neutralidade da tributação e desenvolvimento econômico: a questão da redução das desigualdades regionais e sociais. In: MARTINS, Ives Gandra da Silva et al. (coord.). Incentivos fiscais: questões pontuais nas esferas federal, estadual e municipal. São Paulo: MP, 2007. cap. 1, p. 37-66.

EMMONS, William R.; SCHMID, Frank A. Credit Unions and the Common Bond. Review of the Federal Reserve Bank of St. Louis. p. 41-63, Sep./Oct. 1999.

Banks, Credit Unions, and the Dynamics of Competition. Federal Reserve Bank of St. Louis. Working Paper, 2000a.

Bank Competition and Concentration: Do Credit Unions Matter? Review of the Federal Reserve Bank of St. Louis. p. 29-42, May/June 2000b. 
FABRETTI, Láudio Camargo. Contabilidade tributária. 6. ed. rev. e atualizada. São Paulo: Atlas, 2000.

FÁVERO, Luiz Paulo Lopes et al. Utilização da Anacor para a identificação de meios de pagamento em populações de média e baixa renda. In: IX SEMEAD - Seminários em Administração FEA-USP, 2006, São Paulo.

FEINBERG, Robert M. The Competitive Role of Credit Unions in Small Local Financial Services Markets. Review of Economics and Statistics. Aug. 2001.

Credit Unions: Fringe Suppliers or Cournot Competitors? Review of Industrial Organization. p. 105-113, March 2002a.

The Determinants of Bank Rate-Setting in Local Consumer Lending Markets: Comparing Market and Institution-Level Results. Working Paper, $2002 \mathrm{~b}$.

FERREIRA, José Antonio Stark. Contabilidade de Custos. São Paulo: Pearson Prentice Hall, 2007.

FINANCIAL ACCOUNTING STANDARDS BOARD - FASB. Statement 116: accounting for contributions received and contributions made (Issued 6/93). Disponível em: <http://www.fasb.org/st/summary/stsum116.shtml>. Acesso em: 05/05/2007

FOLHA DE S.PAULO DINHEIRO. Carga alta produz isenções, diz receita. São Paulo, domingo, 01 de julho de 2007. Disponível em: <http://www1.folha.uol.com.br/fsp/dinheiro/fi0107200704.htm>. Acesso em: FORMIGONI, Henrique et al. Investimento em capacitação tecnológica industrial, com incentivo fiscal, e desenvolvimento socioeconômico. In: $\mathbf{8}^{\mathbf{0}}$ Congresso USP Controladoria e Contabilidade. São Paulo, 2008.

FORTE, Denis. Estudo sobre a estrutura de capital das empresas brasileiras no período pós Plano Real (1995-2005). São Paulo, 2007. Tese (Doutorado) - Programa de PósGraduação em Administração de Empresas da Universidade Presbiteriana Mackenzie.

FREITAS, Luis Carlos de, et al. Influência do cálculo de depreciação no imposto de renda e no fluxo de caixa de uma atividade de transporte florestal. Revista Árvore. v. 31, n. 2, p. 257 264, abr. 2007.

GIBRAT, R. Les Inegalities Economiques. Paris: Sirey, 1931.

GITMAN, Lawrence J. Princípios de Administração Financeira. 3. ed. Rio de Janeiro: Harbra, 1987.

GODDARD, John A. et al. The growth of US Credit Unions. Journal of Banking and Finance. v. 26, n. 12, p. 2327-2356. 2002. Disponível em: <http://www.creditunionresearch.com/uploads/law1.pdf>. Acesso em: 23/10/2007.

GORDON, Roger H.; SLEMROD, Joel. A general equilibrium simulation study of subsidies to municipal expenditures. The Journal of Finance. v. 38, n. 2, p. 585-594, May 1983. 
GRAHAM, John R. How Big Are the Tax Benefits of Debt? The Journal of Finance, v. 55, n. 5, p. 1901-1941, Oct., 2000.

GRZYBOVSKI, Denize; HAHN, Tatiana Gaertner. Educação fiscal: premissa para melhor percepção da questão tributária. Revista de Administração Pública. v. 40, n. 5, p. 841-864, set./out. 2006.

GUARNIERI, Patrícia. As vantagens logísticas e tributárias obtidas com a implantação do RECOF na indústria automobilística. Produção. v. 18, n. 1, p. 099-111, jan./abr. 2008.

GUTHMANN, Harry G. Competition from tax-exempt business. The Journal of Finance. v. 6, n. 2, p. 161-177, Jun. 1951.

HAIR JF et al. Análise multivariada de dados. Adonai Schlup Sant'Anna; Anselmo Chaves Neto (trad.). 5. ed.. Porto Alegre: Bookman, 2005.

HANSEN, Don R.; MOWEN, Maryanne M. Gestão de custos: contabilidade e controle. Tradução de Robert Brian Taylor. São Paulo: Pioneira Thomson Learning, 2001.

HANNAN, Timothy $H$. The impact of credit unions on the rates offered for retail deposits by banks and thrift institutions. September, 2002. Avaliable in: <http://www.ssrn.br/id386880>. Acesso em: 28/06/2008.

; PRAGER, Robin A. The Competitive Implications of Multimarket Bank Branching. Working Paper 2001-43, Federal Reserve Board, 2001.

HARADA, Kiyoshi. Incentivos fiscais em face da lei de responsabilidade fiscal. In: MARTINS, Ives Gandra da Silva et al. (Coord.). Incentivos fiscais: questões pontuais nas esferas federal, estadual e municipal. São Paulo: MP., 2007. cap. 12, p. 245-252.

HARRISS, C. Lowell. Government expenditure: significant issues of definition. The Journal of Finance. v. 9, n. 4, p. 351-364, Dec. 1954.

HART, P. E.; OULTON, N. The Size and Growth of Firms. Economic Journal. n. 106, p. 1242-1252, 1996.

; OULTON, N. Gibrat, Galton and job creation. International Journal of the Economics of Business. n. 6, p. 149-164, 1999.

; PRAIS, S. J. The Analysis of Business Concentration: A Statistical Approach. Journal of the Royal Statistical Society. Series A, n. 119, p. 150-191, 1956.

HENDRIKSEN, Eldon S.; VAN BREDA, Michael F. Accounting theory. 5th ed. [S.1.]: Irwin, 1992.

HOWELL, Paul L. The effects of federal income taxation on the form of external financing by business. The Journal of Finance. v. 4, n. 3, p. 208-222, Sep. 1949. 
HUANG, Rogbing; RITTER, Jay R. Testing the market timing theory of capital structure. Kennesaw University and University of Florida, working paper, Set. 2005.

ICHIHARA, Yoshiaki. Imunidades tributárias. São Paulo: Atlas, 2000.

INTERNATIONAL ACCOUNTING STANDARDS BOARD - IASB. IAS 20: accounting for government grants and disclosure of government assistance. Disponível em: <http://www.iasb.org>. Acesso em 17/09/2007.

INTERNATIONAL ACCOUNTING STANDARDS COMMITTEE - IASC. Disponível em: <http://www.iasb.org>. Acesso em 17/09/2007.

INSTITUTO DOS AUDITORES INDEPENDENTES DO BRASIL - IBRACON. NPC XVIII - Contabilização do valor relativo às isenções ou reduções de imposto sobre a renda (aprovada em 01/01/1984). Revogada pela NPC sobre Contabilização de Subvenções Governamentais. Disponível em: 〈http://www.ibracon.com.br〉. Acesso em: 17/09/2007.

JORNAL OFICIAL DA UNIÃO EUROPÉIA. Norma internacional de contabilidade IAS 20 (Reformatada em 1994). Contabilização dos subsídios do governo e divulgação de apoios do governo. L 261/178-183, 13/10/2003.

KEMSLEY, Deen; NISSIM, Doron. Valuation of the debt tax shield. The Journal of Finance. v. 57, n. 5, p. 2045-2073, Oct. 2002.

KÖCHE, José Carlos. Fundamentos da metodologia científica: teoria da ciência e prática da pesquisa. 15. ed. Petrópolis: Vozes, 1999.

LACOMBE, Américo L. Masset. A imunidade tributária das Sociedades de Economia Mista. Revista de Administração de Empresas. Rio de Janeiro, n. 21, p. 129-158, 1966.

Algumas considerações sobre os incentivos fiscais. Revista de Administração de Empresas. Rio de Janeiro, v. 9, n. 4, p. 107-117, out./dez. 1969.

LAMEIRA, Valdir de Jesus et al. Hedge, redução de volatilidade dos lucros e o efeito sobre o imposto de renda das companhias abertas brasileiras. Revista Contabilidade \& Finanças. v. 38, maio/ago. 2005.

LANG T. Twenty statistical errors even you can find in biomedical research articles. Croat Med Journal. v. 45, n. 4, p. 361-370, 2004.

LEFTWICH, Richard H. O sistema de preços e a alocação de recursos. 8. ed. Maria Tereza de Oliveira Audi (trad). São Paulo: Pioneira, 1994.

LEVIN, Jack; FOX, James Alan. Alfredo Alves de Farias (trad.). Estatística para ciências humanas. 9. ed. São Paulo: Pearson Prentice Hall, 2004.

LIMBERG, Stephen T. et al. Financial strategies for minimizing corporate income taxes under Brazil's new global tax system. Revista de Administração de Empresas. São Paulo. v. 37, n. 1, p. 41-52, jan./mar. 1997. 
LOPES, Alexsandro Broedel; MARTINS, Eliseu. Teoria da contabilidade: uma nova abordagem. São Paulo: Atlas, 2005.

LOYOLLA, Waldomiro; FERREIRA, Antonio Sergio Seco. Tax XML - sistema de apoio à cooperação tributária internacional. Revista de Administração de Empresas - Eletrônica. v. 1, n. 1, 2002. Seção: gestão da informação.

MACHADO, Hugo de Brito. Curso de Direito Tributário. 28. ed. rev. atual. e ampl. São Paulo: Malheiros, 2007.

MALHOTRA Naresh K. Pesquisa de marketing: uma orientação aplicada. 3. ed. Porto Alegre: Bookman, 2001.

McGAHAN, Anita M. Competition, Strategy and Performance. California Management Review. n. 41, p. 74-101, 1999.

McGAHAN, Anita M.; PORTER, Michael E. How Much Does Industry Matter, Really? Strategic Management Journal. n. 18, p. 15-30, 1997.

MELO, Fábio Soares de. Incentivos fiscais e segurança jurídica. In: Incentivos fiscais: questões pontuais nas esferas federal, estadual e municipal. MARTINS, Ives Gandra da Silva et al. (coord.). São Paulo: MP, 2007, p. 138-139.

MILLER, Merton H. Debt and taxes. The Journal of Finance. v. 32, n. 2, p. 261-275, May 1977.

MODIGLIANI, F.; MILLER, Merton H. The cost of capital corporation finance and theory of investment. American Economic Review. v. 48., n. 3, p. 261-297, June 1958.

. The cost of capital corporation finance and theory of investment: corporate income and taxes and the cost of capital: a correction. American Economic Review. v. 53., n. 3, p. 433-443, June 1963.

MONTEIRO, Jorge Vianna. A promoção do crescimento econômico em 2007-10. Revista de Administração Pública. Rio de Janeiro, v. 41, n. 2, p. 357-368, mar./abr. 2007

MORAES, Bernardo Ribeiro de. A imunidade tributária e seus novos aspectos. In: MARTINS, Ives Gandra da Silva (coordenador). Imunidades tributárias. São Paulo: Revista dos Tribunais, 1998, p. 363-380. (Pesquisas tributárias. Nova série. n. 4).

MORAIS, José Fausto de. O que precisamos saber antes de falar sobre casuística, métodos e resultados. Revista Estima. v. 1, n. 2, p. 9-11, Jul-Set, 2003.

MYERS, S. The capital structure puzzie. The Journal of Finance. v. XXXIX, p. 572-592, 1984.

MYERS, S.; MAJLUF, Nicolas S. Corporate financing and investment decisions when firms have information that investors do not have. Journal of Finance Economics. v. 13, n. 2, p. 187-221, 1984. 
NELDER, J. A.; WEDDERBURN, R. W. M. Generalized liner models. Journal of the Royal Statistical Society, n. 135, p. 370-384. 1972. This is the seminal article on GLM.

NEVIANI, Tarcísio. O ICM, os inventários e o imposto de renda. Revista de Administração de Empresas. v. 11, n. 2, 1971. Seção: artigos.

NORONHA, José Carvalho de. Os rumos do Estado brasileiro e o SUS: a seguridade social como politica pública da sociedade e Estado. Saúde e Sociologia. v. 14, n. 2, p. 31-38, ago. 2005 .

PAES, Nelson Leitão; BUGARIN, Mirta Noemi Sataka. Reforma tributária: impactos distributivos, sobre o bem-estar e a progressividade. Revista Brasileira de Economia. v. 60, n. 1, p. 33-56, mar. 2006.

PALEPU, Krishna et al. Business analysis \& valuation: using financial statements. 3th ed. New Jersey: Thomson, 2004.

PÊGAS, Paulo Henrique. Manual de contabilidade tributária. 4. ed. rev. e ampl. Rio de Janeiro: Freitas Bastos, 2006.

PEROBELLI, Fernanda Finotti Cordeiro; FAMÁ, Rubens. Fatores determinantes da estrutura de capital: aplicação a empresas de capital aberto no Brasil. Revista de Administração RAUSP. São Paulo, v. 37, n. 3, p.33-46, jul./set. 2002.

PIRES, Adilson Rodrigues. Ligeiras reflexões sobre a questão dos incentivos fiscais no Brasil. In: Incentivos Fiscais: questões pontuais nas esferas federal, estadual e municipal. MARTINS, Ives Gandra da Silva et al. (coord.). São Paulo: MP, 2007, p. 15-35.

POCHMANN, Marcio. Política social na periferia do capitalismo: a situação recente no Brasil. Ciência \& Saúde Coletiva. v. 12, n. 6, p. 1477-1489, 2007.

POHLMANN, Marcelo Coletto. Contribuição ao estudo da classificação interdisciplinar da pesquisa tributária e do impacto da tributação na estrutura de capital das empresas no Brasil. São Paulo, 2005. Tese (Doutorado) - Programa de Pós-Graduação em Ciências Contábeis, Departamento de Contabilidade e Atuária, Faculdade de Economia, Administração e Contabilidade da Universidade de São Paulo.

POLI, Beatriz Trois Cunha; PROCIANOY, Jairo Laser. A política de dividendos como geradora de economia fiscal e do desenvolvimento do mercado de capitais: uma proposta criativa. Revista de Administração de Empresas. v. 33, n. 4, 1993. Seção: Artigos.

PONCIANO, Niraldo José; CAMPOS, Antônio Carvalho. Eliminação dos impostos sobre as exportações do agronegócio e seus efeitos no comportamento da economia. Revista Brasileira de Economia. Rio de Janeiro, v. 57, n. 3, p. 637-658, jul./set. 2003.

PORTAL EXAME. Ações da Positivo despencam 11,6\% com suspensão de incentivos fiscais. Disponível em: <http://portalexame.abril.com.br/financas/m0139065.html>. Acesso em: 21/09/2007. 
PORTO; Silvia Marta. Equidade na Distribuição Geográfica dos Recursos em Saúde: Uma Contribuição para o Caso Brasileiro. Rio de Janeiro, 1997. 193 f. Tese (Doutorado em Planejamento em Saúde) Escola Nacional de Saúde Pública/ Fundação Oswaldo Cruz.

PRADO FILHO, José Francisco do; SOBREIRA, Frederico Garcia. Desempenho operacional e ambiental de unidades de reciclagem e disposição final de resíduos sólidos domésticos financiadas pelo ICMS ecológico de Minas Gerais. Revista Engenharia Sanitária e Ambiental. v. 12, n. 1, p. 52-61, jan./mar. 2007.

PROCIANOY, Jairo Laser; SCHMITT, Francisco O. O pacote fiscal de 1995: estratégias que otimizam os recursos dos investidores. Revista de Administração de Empresas. São Paulo. v. 35, n. 5, p. 46-58, set./out. 1995.

RICHARDSON, Roberto Jarry. Pesquisa social: métodos e técnicas. São Paulo: Atlas, 1999.

RODRIGUES, Marilene Talarico Martins. Incentivos fiscais: desenvolvimento econômico e a jurisprudência do STG para o ICMS - "guerra fiscal" entre estados. In: MARTINS, Ives Gandra da Silva et al. (coord.). Incentivos fiscais: questões pontuais nas esferas federal, estadual e municipal. São Paulo: MP, 2007. cap. 15, p. 299-325.

ROESCH, Sylvia Maria. Analisando a implementação de políticas públicas: o caso da Lei no 6.297/78, de incentivos fiscais à formação profissional nas empresas. Revista de Administração de Empresas. Rio de Janeiro. v. 24, n. 4, p. 265-277, out./dez. 1984.

O impacto do programa de incentivos ao treinamento nas empresas. Revista de Administração de Empresas. São Paulo. v. 30, n. 1, p. 27-43, jan./mar. 1990.

ROSSETTI, José P. Introdução à Economia. São Paulo: Atlas, 2001.

RUMMELT, Richard P. How Much Does Industry Matter? Strategic Management Journal. n. 12, p. 167-185, 1991.

SABBAG, Eduardo de Moraes. Elementos do direito: direito tributário. 8. ed. São Paulo: Premier Máxima, 2006.

SAMPIERI, Roberto Hernández et al. Metodología de Pesquisa. Tradução de Fátima Conceição Murad et al. 3. ed. São Paulo: McGraw-Hill, 2006.

SAMUALS, J. M.; CHESHER, A. D. Growth, Survival and Size of Companies, 1960-1969. In: Cowling, K. (ed.) Market Structure and Corporate Behaviour, London: Gray-Mills, 1972.

SANTOS, Antonio Raimundo. Metodologia científica: a construção do conhecimento. 2. ed. Rio de Janeiro: DP\&A, 1999.

SANTOS, Sergio Del Porto; CANDIOTA, Luiz Roberto Salgado. Sociedade de crédito imobiliário: o único setor financeiro cuja expansão e rentabilidade estão garantidas por décadas. Revista de Administração de Empresas. Rio de Janeiro, v. 14, n. 1, p. 69-78, jan./fev. 1974. 
SANTOS, Cárliton Vieira dos; FERREIRA FILHO, Joaquim Bento de Souza. Efeitos potenciais da política tributária sobre o consumo de alimentos e insumos agropecuários: uma análise de equilíbrio geral inter-regional. Revista de Economia Sociológica Rural. v. 45, n. 4, p. 921-962, dez. 2007,

SAYD, Patrícia Dutra. Renúncia fiscal e eqüidade na distribuição de recursos para a saúde. 2003. Disponível em: <http://www.abres.cict.fiocruz.br/docs/22.pdf>. Acesso em 26/07/2008.

SAYEG, Roberto Nathan. Sonegação tributária e complexidade. Revista de Administração de Empresas - Eletrônica. v. 2, n. 1, 2003. Seção: administração pública.

SCHARLACK, José Rubens. INCENTIVOS FISCAIS E PLANEJAMENTO EMPRESARIAL. Disponível em: <http://www.rodantescharlack.com.br/pdf/joserubens/artigo-planejamento-tributario.pdf $>$. Acesso em: 04/10/2008.

SCHOUERI, Luís Eduardo A restituição de impostos indiretos no sistema jurídico-tributário brasileiro. Revista de Administração de Empresas. v. 27, n.1, 1987. Seção: artigos

SEIXAS FILHO, Aurélio Pitanga. Teoria e prática das isenções tributárias. Rio de Janeiro: Forense, 1989.

SIEGEL, Sidney. Nonparametric statistics for the behavioral science. New York: McGrawHill, 1956.

SILVA, Edgard Neves da. Imunidade e isenção. In: MARTINS, Ives Gandra da Silva (coordenador). Curso de direito tributário. 8. ed. São Paulo: Saraiva, 2001, p. 207-223.

SIMÕES, Auriphebo Berrance. Michaellis: dicionário executivo inglês-português. Administração, economia, marketing. Glossário português-inglês. São Paulo: Melhoramentos, 1989.

SINGH, A.; WhITtington, G. Growth, Profitability and Valuation. Cambridge: Cambridge University Press, 1968

SINGH, A.; WHITTINGTON, G. The Size and Growth of Firms. Review of Economic Studies. n. 42, p. 15-26, 1975.

SIQUEIRA, Rozane Bezerra de, et al. A incidência final dos impostos indiretos no Brasil: efeitos da tributação de insumos. Revista Brasileira de Economia. vol. 55, n. 4, p .513-544, set. 2001.

SIQUEIRA, Marcelo Lettieri; RAMOS, Francisco S. A economia da sonegação: teorias e evidências empíricas. Revista de Economia Contemporânea. vol. 9, n. 3, p. 555-581, dez. 2005.

SMITH, D. J. A Test for Variant Objective Functions in Credit Unions. Applied Economics. n. 18 , p. $959-970,1986$ 
SOMERS, Harold M. Competition from tax-exempt business: discussion. The Journal of Finance. v. 6, n. 2, p. 178-186, Jun. 1951.

SPIEGEL, Murray Ralph. Estatística. 2. ed. Carlos Augusto Crusius (trad.). São Paulo: Mc Graw-Hill do Brasil, 1985.

STIGLITZ, Joseph E. Financial structure matters. Journal of Economic Perspectives. v. 2, n. 4, p. 121-126, Fall 1988.

TATOM, John A. Competitive advantage: a study of the federal tax exemption for credit unions. Tax Foundation. February 2005. Disponível em: <http://www.ssrn.com/abstract=923110>. Acesso em: 20/10/2007.

TITMAN, Sheridan.; WESSELS; Roberto. The determinants of capital structure choice. The Journal of Finance. v. 43, n. 1, p. 1-19, Mar. 1988.

TOKLE, Robert J.; TOKLE; Joanne G. The Influence of Credit Union and Savings and Loan Competition on Bank Deposit Rates in Idaho and Montana. Review of Industrial Organization. n. 17, p. 427-438, 2000.

TORRES, Ricardo Lobo. O princípio da isonomia, os incentivos do ICMS e a jurisprudência do STF sobre a guerra fiscal. In: MARTINS, Ives Gandra da Silva et al. (Coord.). Incentivos fiscais: questões pontuais nas esferas federal, estadual e municipal. São Paulo: MP, 2007. cap. 16, p. 327-345.

UGÁ, Maria Alicia Dominguez; SANTOS, Isabela Soares. Uma análise da progressividade do financiamento do Sistema Único de Saúde (SUS). Caderno de Saúde Pública. v. 22, n. 8, p. 1597-1609, ago. 2006.

VASCONCELOS, Flávio Carvalho de; BRITO, Luiz Artur Ledur. Vantagem competitiva: o construto e a métrica. Revista de Administração de Empresas. v. 44, n. 2, p. 51 62, Abr/Jun 2004.

VAZQUEZ, Daniel Arias. Desequilíbrios regionais no financiamento da educação: a política nacional de equidade do FUNDEF. Revista de Sociologia Política. n. 24, p. 149-164, jun. 2005 .

WAGNER, J. Firm Size, Growth and the Persistence of Chance. Small Business Economics. n. 4, p. 125-131, 1992. WILKS, S. S. Certain generalizations in the analysis of variance. Biométrica, v. 24, p. :471-94, 1932.

WILKS, S. S. Certain generalizations in the analysis of variance. Biométrica, v. 24, p. 47194, 1932. 
